Environmental Restoration Division

Off-Site Investigations Environmental Restoration Program

\title{
Preliminary Screening of Contaminants in the Off-Site Surface Water Environment Downstream of the U.S. Department of Energy Oak Ridge Reservation
}

F. O. Hoffman, B. G. Blaylock, M. L. Frank, L. A. Hook, E. L. Etnier, S. S. Talmage

Date Issued-November 1991

Prepared by Environmental Sciences Division Oak Ridge National Laboratory ESD Publication 3485

Prepared for U.S. Department of Energy

Office of Environmental Restoration and Waste Managernent under budget and reporting codes CD 1072 and EW 20

OAK RIDGE NATIONAL LABORATORY

Oak Ridge, Tennessee 37831-6285

managed by

MARTIN MARIETTA ENERGY SYSTEMS, INC. for the U.S. DEPARTMENT OF ENERGY under contract DE-AC05-84OR21400 


\section{Author Affiliations}

F. O. Hoffman, B. G. Blaylock, and M. L. Frank are members of the Environmental Sciences Division, Oak Ridge National Laboratory, Martin Marietta Energy Systems, Inc. L. A. Hook is affiliated with Science Applications International Corporation, Oak Ridge, Tennessee. E. L. Etnier and S. S. Talmage are members of the Health and Safety Research Division, Oak Ridge National Laboratory.

\section{Note to Recipients of ORNL/ER-9}

The draft version of this report was distributed in March 1990. Only minor changes were made for this final version; substantial revisions to the draft were unnecessary.

Environmental Restoration Program Martin Marietta Energy Systems, Inc. 


\section{CONTENTS}

ACKNOWLEDGEMENTS $\ldots \ldots \ldots \ldots \ldots \ldots \ldots \ldots \ldots \ldots \ldots \ldots \ldots \ldots$

ABSTRACT $\ldots \ldots \ldots \ldots \ldots \ldots \ldots \ldots \ldots \ldots \ldots \ldots \ldots \ldots \ldots \ldots \ldots \ldots$

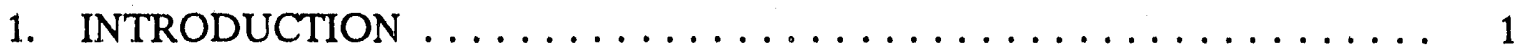

2. APPROACH ......................... 2

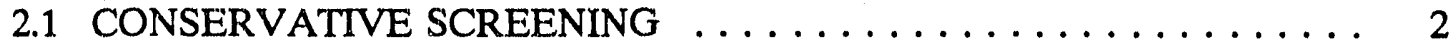

2.1.1 Exposure Pathways for Conservative Screening ........... 4

2.1 .2 Criteria for Conservative Screening . . . . . . . . . . 7

2.1.3 Screening Indices for Carcinogens and Noncarcinogens .................. 7

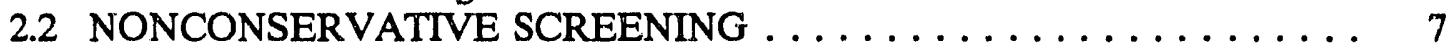

2.2.1 Exposure Pathways for Nonconservative Screening . . . . . . . . . . 9

2.2.2 Screening Indices for Carcinogens and Noncarcinogens . . . . . . . . 9

2.2.3 Criteria for Nonconservative Screening . . . . . . . . . . . . 9

3. DESCRIPTION OF SURFACE WATER REACHES AND

DEVELOPMENT OF SOURCE TERM DATA BASE . . . . . . . . . . 11

3.1 RIVER AND STREAM REACHES $\ldots \ldots \ldots \ldots \ldots \ldots \ldots \ldots \ldots \ldots$

3.2 SOURCES OF IISFORMATION $\ldots \ldots \ldots \ldots \ldots \ldots \ldots \ldots \ldots \ldots \ldots$

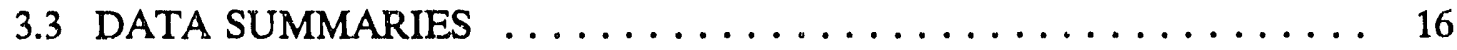

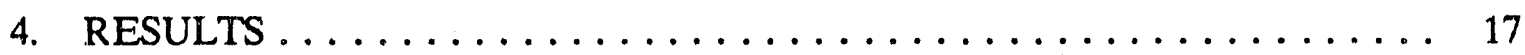

4.1 HIGH-PRIORITY CONTAMINANTS IDENTIFIED THROUGH

NONCONSERVATIVE SCREENING . . . . . . . . . . . . . . 17

4.2 PO'TENTIALLY HIGH PRIORITY CONTAMINANTS IDENTIFIED

THROUGH CONSERVATIVE SCREENING . . . . . . . . . . . 21

4.3 DEFINITELY LOW PRIORITY CONTAMINANTS IDENTIFIED

THROUGH CONSERVATTVE SCREENING . . . . . . . . . . . . . 27

4.4 POTENTIALLY LOW PRIORITY CONTAMINANTS IDENTIFIED

THROUGH NONCONSERVATTVE SCREENING . . . . . . . . . . 30

4.5 CONTAMINANTS DESIGNATED AS NEITHER HIGH NOR

LOW PRIORITY . ...................... 31

4.6 COMPARISON OF SCREENING RESULTS USING HEALTH

RISK AND ECOLOGICAL END POINTS . . . . . . . . . . . . . 39

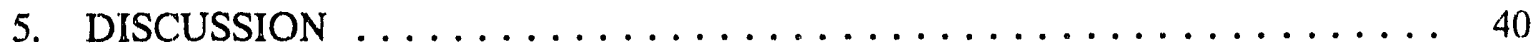

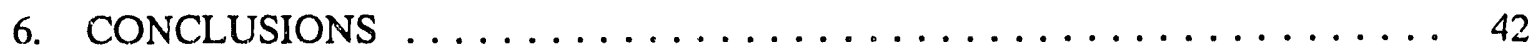

7. REFERENCES ......................... 43 
Appendix A - REFERENCE DOSE FACTORS AND SLOPE (CANCER . . . . . 47 POTENCY) FACTORS FOR ORGANIC AND INORGANIC CHEMICALS AND RADIONUCLIDES

Appendix B - MAXIMUM AND MEAN CONCENTRATIONS OF $\ldots \ldots \ldots 5$ ORGANIC AND INORGANIC CHEMICALS AND RADIONUCLIDES IN SEDIMENT, FISH, AND WATER FOR EACH STREAM REACH

Appendix C - RESULTS OF CONSERVATIVE SCREENING . . . . . . . . 79

Appendix D - RESULTS OF NONCONSERVATTVE SCREENING . . . . . . . . 113

Appendix E - RESULTS OF NONCONSERVATIVE SCREENING $\ldots \ldots \ldots$. . 127 FOR THE LOWEST REPORTED LESS-THAN-DETECTABLE QUANTITIES OF CONTAMINANTS

Appendix F - COMPARISON OF SCREENING RESULTS USING $\ldots \ldots \ldots \ldots$ HEALTH RISK AND ECOLOGICAL END POINTS

DISTRIBUTION $\ldots \ldots \ldots \ldots \ldots \ldots \ldots \ldots \ldots \ldots \ldots \ldots \ldots \ldots \ldots \ldots$ 


\section{LIST OF FIGURES}

2.1 Exposure pathways considered for the Clinch River off-site . . . . . 5 screening analysis.

3.1 Reach 1. on Melton Hill Reservoir, Reach 2 on the Clinch ....... River, and Reach 3 on Poplar Creek receive effluents from the Oak Ridge facilities. Reach 13 on Poplar Creek is a reference reach.

3.2 Reach 4 on the Clinch River and Reach 5, Watts Bar Reservoir, .. 13 are downstream from the Oak Ridge Reservation and receive effluents from all Oak Ridge facilities. Reach 10, Norris Reservoir, and Reach 18 on the Tennessee River are reference reaches.

4.1 A comparison of pathway totalled screening indices by reach $\ldots .18$ for carcinogens (Fig. 4.1A) and noncarcinogens (Fig. 4.1B) using nonconservative estimates of exposure. 


\section{LIST OF TABLES}

2.1 A comparison of conservative and nonconservative screening . . . . 3 approaches

Usage factors for conservative and nonconservative screening $\ldots \ldots 6$

2.3 Criteria for conservative and nonconservative screening of $\ldots \ldots 8$ carcinogens and noncarcinogens

3.1 River and stream reaches and associated facilities to be $\ldots \ldots \ldots 14$ evaluated in the Clinch River RCRA Facility Investigation

3.2 Sources of data on contaminant concentrations in fish, water, . . . 15 and sediment in off-site surface water used to develop a data base for screening analyses

4.1 Contaminants assigned either a definitely or potentially high $\ldots \ldots 19$ priority through nonconservative screening

4.2 Contaminants assigned a potentially high priority through $\ldots \ldots 22$ conservative screening

4.3 Contaninants assigned a definitely low priority through $\ldots \ldots \ldots 28$ conservative screening

4.4 Contaminants assigned a potentially low priority through $\ldots \ldots \ldots 31$ nonconservative screening

4.5 Contaminants within a given reach assigned both a potentially $\ldots . .36$ low priority through nonconservative screening and a potentially high priority using conservative screening

4.6 Potential contaminants detected in either sediment, water, or . . . 38 fish within a given reach for which no valuas were obtained for either reference dose factors or cancer slope factors

A1 Reference dose factors and slope (cancer potency) factors . . . . . 49 for inorganic compounds

A2 Reference dose factors and slope (cancer potency) factors . . . . 50 for organic chemicals 
A3 Dose conversion factors for radionuclides $\ldots \ldots \ldots \ldots \ldots \ldots, 54$

B1 Maximum concentration of inorganic compounds in sediment, .... 57 fish, and water

B2 Maximum concentrations of organic chemicals in sediment, . . . . 60 fish, and water

B3 Maximum concentrations of radionuclides in sediment, . . . . . 70 fish, and water

B4 Mean concentrations of inorganic chemicals in sediment, $\ldots \ldots \ldots 72$ fish, and water

B5 Mean concentrations of organic chemicals in sediment, $\ldots \ldots \ldots 75$ fish, and water

B6 Mean concentrations of radionuclides in sediment, $\ldots \ldots \ldots \ldots 76$ fish, and water

C1a Summation screening indices for carcinogens by .......... 81 pathways and contaminant type. (Exposure pathways based on consumption of water and fish and the assumed use of water for irrigation.)

C1b Summation screening indices for carcinogens by . . . . . . . 83 pathways and contaminant type. (Exposure pathways based on assumed dredging of sediment and its subsequent use as agricultural soil.)

C2a Carcinogen screening indices for inorganic compounds $\ldots \ldots \ldots 85$ using maximum concentrations and conservative estimates of exposure. (Exposure pathways based on consumption of water and fish and the assumed use of water for irrigation.)

$\mathrm{C} 2 \mathrm{~b} \quad$ Carcinogen screening indices for organic compounds $\ldots \ldots \ldots . \quad 87$ using maximum concentrations and conservative estimates of exposure. (Exposure pathways based on assumed dredging of sediment and its subsequent use as agricultural soil.)

C3a Carcinogen screening indices for organic compounds $\ldots \ldots \ldots . .89$ using maximum concentrations and conservative estimates of exposure. (Exposure pathways based on consumption of water and fish and the assumed use of water for irrigation.) 
C.3b Carcinogen screening indices for organic compounds $\ldots \ldots \ldots \ldots 91$ using maximum concentrations and conservative estimates of exposure. (Exposure pathways based on assumed dredging of sediment and its subsequent use as agricultural soil.)

C4a Carcinogen screening indices for radionuclides $\ldots \ldots \ldots \ldots \ldots$ using maximum concentrations and conservative estimates of exposure. (Exposure pathways based on consumption of water and fish and the assumed use of water for irrigation.)

$\mathrm{C} 4 \mathrm{~b} \quad$ Carcinogen screening indices for radionuclides $\ldots \ldots \ldots \ldots \ldots 7$ using maximum concentrations and conservative estimates of exposure. (Exposure pathways based on assumed dredging of sediment and its subsequent use as agricultural soil.)

C5a Summation screening indices for noncarcinogens by $\ldots \ldots \ldots \ldots 100$ pathways and contaminant type. (Exposure pathways based on consumption of water and fish and the assumed use of water for irrigation.)

$\mathrm{C} 5 \mathrm{~b} \quad$ Summation screening indices for noncarcinogens by . . . . . . . . 101 pathways and contaminant type. (Exposure pathways based on assumed dredging of sediment and its subsequent use as agricultural soil.)

C6a Noncarcinogen screening indices for inorganic compounds . . . . 102 using maximum concentrations and conservative estimates of exposure. (Exposure pathways based on consumption of water and fish and the assumed use of water for irrigation.)

C6b Noncarcinogen screening indices for inorganic compounds . . . . . 16 6 using maximum concentrations and conservative estimates of exposure. (Exposure pathways based on assumed dredging of sediment and its subsequent use as agricultural soil.)

C7a Noncarcinogen screening indices for organic compounds $\ldots \ldots \ldots 10$ ? using maximum concentrations and conservative estimates of exposure. (Exposure pathways based on consumption of water and fish and the assumed use of water for irrigation.)

C7b Noncarcinogen screening indices for organic compounds $\ldots \ldots \ldots 111$ using maximum concentrations and conservative estimates of exposure. (Exposure pathways based on assumed dredging of sediment and its subsequent use as agricultural soil.) 
D1 Summation of screening indices for carcinogens by reach, . . . . . 115 exposure pathway, and contaminant type using mean concentrations and nonconservative estimates of exposure

D2 Summation of screening indices for noncarcinogens by reach, . . . 116 exposure pathway, and contaminant type using mean concentrations and nonconservative estimates of exposure

D3 Carcinogen screening indices for inorganics by reach $\ldots \ldots \ldots \ldots 11 \%$ and pathway using mean concentrations with nonconservative estimates of exposure

D4 Carcinogen screening indices for organics by reach . . . . . . . 118 and pathway using mean concentrations and nonconservative estimates of exposure

D5 Carcinogen screening indices for radionuclides by reach . . . . . 120 and pathway using mean concentrations and nonconservative estimates of exposure

D6 Noncarcinogen screening indices for inorganics by reach . . . . . . 123 and pathway using mean concentrations and nonconservative estimates of exposure

D7 Noncarcinogen screening indices for organics by reach . . . . . 126 and pathway using mean concentrations and nonconservative estimates of exposure

E1 Lowest limits of detection reported in the data base . . . . . . . . 129 for inorganic compounds

E2 Lowest limits of detection reported in the data base $\ldots \ldots \ldots \ldots 130$ for organic compounds

E3 Lowest limits of detection reported in the data base $\ldots \ldots \ldots \ldots$ for radionuclides

E4 Carcinogen screening indices for inorganics by pathway $\ldots \ldots \ldots \ldots 134$ using lowest limits of detection reported in data base and nonconservative estimates of exposure

E5 Carcinogen screening indices for organics by pathway . . . . . 135 using lowest limits of detection reported in data base and nonconservative estimates of exposure 
E6 Carcinogen screening indices for radionuclides by pathway $\ldots \ldots \ldots 137$ using lowest limits of detection reported in data base and nonconservative estimates of exposure

E7 Noncarcinogen screening indices for inorganics by pathway . . . . . 138 using lowest limits of detection reported in data base and nonconservative estimates of exposure

E8 Noncarcinogen screening indices for organics toy pathway . . . . . . 139 using lowest limits of detection reported in data base and nonconservative estimates of exposure

F1 Comparison of contaminants assigned a potentially high $\ldots \ldots \ldots 144$ priority through conservative screening by health risk criteria (this study) with those screened by environmental risk criteria 


\section{ACKNOWIEDGEMENTS}

The authors wish to express their sincere appreciation to John Trabalka and George Southworth of the Environmental Sciences Division for their many helpful suggestions in regards to specific contaminants. We wish to express our gratitude to Bruce Kimmel, Larry Barnthouse, and Steve Bartell of the Environmental Sciences Division, and Robert Ross of the Health and Safety Research Division for in-depth reviews of the manuscript and many helpful suggestions. Mary Alice Faulkner of the Environmental Sciences Division deserves our expression of appreciation for help in developing the data base, and we are indeed grateful to Jeannette Cox of the Environmental Sciences Division whose cooperative attitude and secretarial skill facilitated the production of the document. 


\begin{abstract}
Previously reported concentrations of radionuclides and of inorganic and organic compounds in the surface water environment off-site of the U.S. Department of Energy/Oak Ridge Reservation (DOE/ORR) suggest the presence of a large number of substances of possible concern to the protection of human health and the ecosystem. Screening of these data, as part of the initial scoping phase of the Clinch River Resource Conservation and Recovery Act Facility Investigation, is necessary to develop a field sampling plan for the acquisition of additional data through the identification of potential contaminants of concern for further evaluation and investigation. The results of this report are based on human health risk end points. For the purposes of screening, conservative and nonconservative estimates of potential maximum exposures were used to identify, respectively, definitely lowand definitely high-priority pollutants. Because of relatively high concentrations of contaminants in sediment, the presence of industrial and agricultural wastes not related to DOE/ORR operations, and the use of a lifetime risk for carcinogens of $10^{-6}$ as a lower screening criterion, no surface water reach considered in this study was identified as low priority. In contrast to this result, three contaminants, arsenic in water and thallium in fish of McCoy Branch and ${ }^{137} \mathrm{Cs}$ in the sediment of the White Oak Creek embayment downstream from White Oak Lake, were tentatively identified as definitely high-priority substances. These locations are within the boundaries of ORR. Nonconservative estimates of exposure identified arsenic, antimony, thallium, uranium, polychlorinated biphenyls 1254 and 1260 , chlordane, ${ }^{60} \mathrm{Co}$, and ${ }^{24} \mathrm{~Pa}$ as potentially high-priority contaminants in at least one or more locations. These are the contaminants that should receive the most scrutiny in future investigations. Such scrutiny should include a thorough evaluation of all potentially exposed population groups and the evidence used to derive carcinogen slope factors and/or noncarcinogen reference doses. With few exceptions, all of the chemicals screened as potential contaminants of concern with environmental/ecological end points were also identified using human health risk end points.
\end{abstract}




\section{INTRODUCTION}

Operations and waste disposal activities at the Y-12 Plant, the Oak Ridge National Laboratory (ORNL), and the Oak Ridge Gaseous Diffusion Plant (ORGDP), located on the U.S. Department of Energy (DOE) Oak Ridge Reservation (ORR) in eastern Tennessee, have introduced a variety of airborne, liquid, and solid wastes into the surrounding environment (Rogers et al. 1988, 1989). Some of these wastes may affect offsite areas (i.e., areas beyond the ORR boundary) by entering local streams that ultimately drain into the systems of the Clinch and Tennessee rivers. Previously reported concentrations of radionuclides, metals, and organic compounds in water, sediment, and biota of the Clinch River and Watts Bar Reservoir suggest the presence of a variety of contaminants of possible concern to the protection of human health and the environment.

DOE has initiated a comprehensive waste management and environmental restoration effort to achieve the remediation of releases of hazardous substances, pollutants, or contaminants from the Oak Ridge Reservation (Jones et al. 1990). This effort has been undertaken in accordance with the draft. Federal Facility Agreement (FFA) between the Environmental Protection Agency (EPA) Region IV, the State of Tennessee, and DOE. The FFA requires that the cleanup of ORR and environs be conducted in compliance with both the Resource Conservation and Recovery Act (RCRA) of 1976, as amended by the Hazardous and Solid Waste Amendments (HWSA) of 1984, and the Comprehensive Environmental Response, Compensation, and Liability Act (CERCLA) of 1980, as amended by the Superfund Amendments and Reauthorization Act (SARA) of 1986.

This preliminary screening of contaminants in the off-site surface water environment downstream of the DOE ORR represents part of the scoping phase of the Clinch River RCRA Facility Investigation (CRRFI), which is a component of the DOE Environmental Restoration Program at Oak Ridge. The primary objectives of CRRFI are to (1) define the nature and extent of off-site surface water contamination, (2) quantify the potential risk to human health and to the environment associated with off-site contamination, and (3) identify and preliminarily evaluate potential remediation alternatives.

The purpose of this preliminary screening analysis is to use existing data on off-site contaminant concentrations to identify and prioritize potential contaminants of concern for further evaluation and investigation. The primary objective of this screening analysis is to ensure that CRRFI sampling and analysis efforts focus on those contaminants that may possibly contribute to human health or environmental risk.

This report presents the results of contaminant screening using human health indices as an end point. A companion report by Suter (1990) addresses the screening results using environmental/ecological risk as an end point. A comparison of screening results using both human health and environmental risk end points is included in the discussion section of this report.

These analyses are preliminary scoping exercises based on existing data; they do not constitute a base-line risk assessment, and they are not intended to address issues regarding compliance with regulatory limits. The base-line risk assessment will include data obtained from the field sampling and sample analysis plan and will employ more realistic assiomptions than those used for preliminary screening. 


\section{APPROACH}

Two approaches are taken in this screening exercise (Table 2.1). The first approach is the use of conservatively biased calculations to identify contaminants and exposure pathways that should have a low priority for further analyses and data acquisition. Conservative calculations are unlikely to underestimate potential maximum exposures and thus may substantially overestimate the majority of actual exposures received by persons residing in the vicinity of the off-site environment. The second approach uses nonconservative calculations and assumptions to identify contaminants that should have highest priority for further evaluation and/or possible remediation. Nonconservative calculations provide a more realistic estimate and should not substantially overestimate maximum exposures to local population subgroups. These two screening approaches are intended to rapidly identify contaminants of concern and to guide the acquisition of more extensive data relevant to these contaminants.

The evaluation of the risk to humans and the environment will be an iterative process. The accuracy of the assessment will improve and the number of contaminants of concern should decrease with the acquisition of more complete data. Contaminants not identified as definitely low- or high-priority substances during the first iteration of screening are likely to be reclassified as additional data and information are obtained.

\subsection{CONSERVATIVE SCREENING}

Contaminant concentrations can be assigned a definite low priority for further study if a conservative estimate of health and environmental risk is sufficiently small. The conservative approach is based on the maximum reported concentration for a given contaminant and medium within a given reach of the off-site surface water environment. This extreme value is employed in accordance with recent EPA risk assessment guidance (USEPA 1989a) because existing data are not adequate for estimating an average concentration representative of possible lifetime exposure of a human receptor. The conservative approach also assumes, unrealistically, that individuals are exposed continuously to this maximum concentration for 70 years.

Concentrations of contaminants in environmental media for which data are unavailable are estimated using pathway models that employ conservative assumptions and transfer coefficients appropriate for screening calculations. When the concentration of a contaminant in a specific environmental medium is below the limits of analytical detection, models are used to conservatively estimate a concentration in that medium from concentrations reported in other media at or near the location of interest. In this case, concentrations are equal to the detection limits only when calculated concentrations exceed the reported limits. However, contaminants that are below the limits of detection in all samples taken from all environmental media at a given location are not included in these analyses. In these special cases, the limits of detection are evaluated separately assuming that the actual concentrations were equal to the lowest reported limits of detection. 
Table 2.1 A comparison of conservative and nonconservative screening approaches

\section{APPROACHES TO SCREENING}

\section{Conservative Screening}

Maximum concentration reported for a given reach used

Models used to estimate concentrations in media that are not sampled or detected

Reasonable estimate of maximum diet and occupancy times assumed

Human receptor exposed for 70 years

Multiple pathway exposure considered

Exposure to dredged sedimeni considered separately from the consumption of water, fish, and irrigated agricultural produce

Calculated exposure should not underestimate actual maximum exposures

Screening approach most useful for identifying definitely low priority contaminants.
Nonconservative Screening

Average of detected values reported for a given reach used

Only measured concentrations in sediment, water, or fish are considered

Estimates of diet and occupancy times are generally a factor of 10 less than assumed for reasonable maximum

Probability of exposure period being less than 70 years considered in estimates of diet and occupancy times

Multiple pathway exposure not considered

Dredging of sediment not considered

Use of water for irrigation not considered

Calculated exposure should not overestimate potential maximum exposures

Screening approach most useful for identifying definitely and potentially high priority contaminants. 
The models and parameter values employed in this analysis were obtained primarily from references that specifically propose methodologies for contaminant screening ${ }^{1}$ (Hoffman et al. 1984, Travis et al. 1989, IAEA 1982, NCRP 1989). Where available screening procedures did not include recommended default values for a given contaminant, additional literature (Baes et al. 1984, Baes et al. 1989, Lappenbush 1988, Lyman et al. 1982) and site-specific data were evaluated, along with the use of professional judgment, to select values that would lead to a conservative estimate of exposure.

\subsubsection{Exposure Pathways for Conservative Screening}

For conservative screening, two exposure scenarios are considered separately. The first is a multiple pathway exposure scenario involving the ingestion of fish and water, and the consumption of vegetables, surface soil, milk, and meat that have been contaminated by river water used for irrigation. Inhalation of contaminants through wind resuspension of dust particles is also included as is the external exposure from gamma radiation emitted from radionuclides arising from irrigation water deposited onto surface soil.

The second scenario involves the assumption that sediment would be excavated through dredging and used as surface soil. For this dredging scenario, multiple exposures occur through incidental ingestion of surface soil; consumption of vegetables, milk, and meat produced on contaminated dredged sediment; and inhalation of resuspended dust particles, as well as external exposure to gamma radiation emitted from radionuclides in sediment. In this scenario, the contaminant concentration in surface soil is set equal to the maximum concentration reported in sediment regardless of the depth of the reported concentration. The aquatic and terrestrial pathways included in these scenarios are illustrated in Fig. 2.1.

The exposure pathways recommended by EPA for base-line risk assessment that have not been included in this conservative screening analysis are dermal contact with the contaminated medium and the inhalation of volatile organic compounds deposited either in sediment or soil (USEPA 1989a). Approaches for these pathways were under development at the time of preparation of this document (USEPA 1989b). These pathways are not expected to significantly impact the pathways and assumptions we have selected for conservative screening. However, a more detailed evaluation of these two exposure routes will be conducted during the first phase of the base-line risk assessment to ensure that a low priority of concern is not inadvertently assigned to a potential contaminant of concern.

For screening analyses of multiple pathway exposures, reasonable, maximum estimates of dietary habits and occupancy factors are used instead of absolute maximum values. These practices are made given that the maximum estimate for the use of a specific pathway is not likely to apply to a single individual exposed to all pathways simultancously. The assumed dietary habits and occupancy times (usage factors) are given in Table 2.2.

${ }^{1}$ Many of the models and parameter values used for conservative screening were taken from screening methodologies developed for the National Council on Radiation Protection and Measurements (NCRP) by Task Group 6 of NCRP Scientific Committee 64. Two of the authors of the present document, F. O. Hoffman and B. G. Blaylock, serve as members of this Task Group. An NCRP report on screening methodologies for releases to the atmosphere, surface water, and groundwater is currently in preparation. 


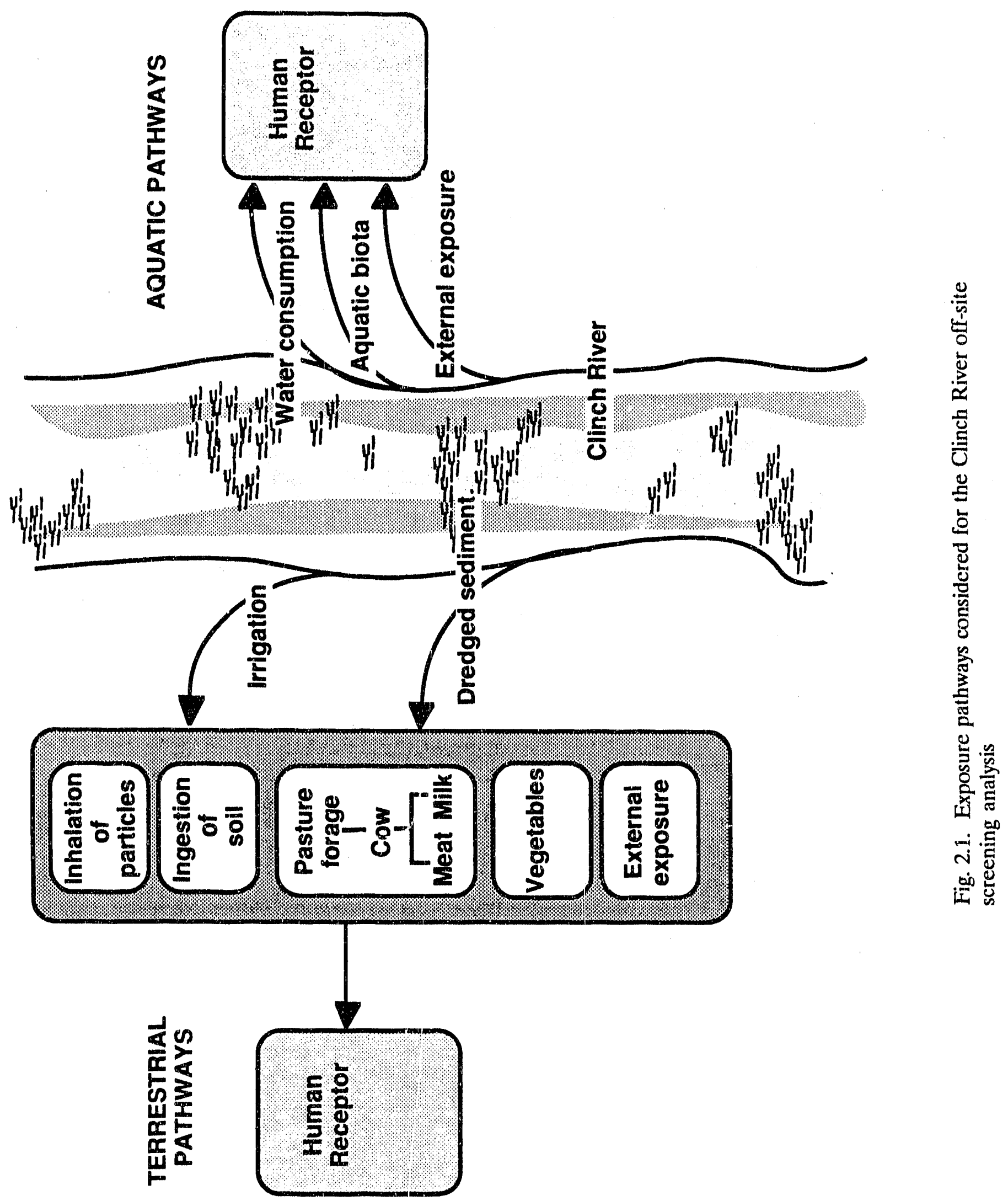


Table 2.2. Usage factors for conservative and nonconservative screening

\begin{tabular}{|c|c|c|}
\hline $\begin{array}{l}\text { Exposure } \\
\text { route }\end{array}$ & $\begin{array}{l}\text { Conservative } \\
\text { screening }\end{array}$ & $\begin{array}{l}\text { Nonconservative } \\
\text { screening }\end{array}$ \\
\hline Ingestion & & \\
\hline $\begin{array}{l}\text { Aquatic biota } \\
\text { Drinking water }\end{array}$ & $\begin{array}{l}20 \mathrm{~g} \mathrm{~d}^{\cdot 1} \\
2 \mathrm{~L} \mathrm{~d}^{-1 a}\end{array}$ & $\begin{array}{l}3 \mathrm{~g} \mathrm{~d}^{-1} \\
0.25 \mathrm{~L} \mathrm{~d}^{-1}\end{array}$ \\
\hline $\begin{array}{l}\text { Terrestrial foods } \\
\text { Milk } \\
\text { Meat } \\
\text { Vegetables }\end{array}$ & $\begin{array}{l}0.5 \mathrm{~L} \mathrm{~d}^{-1} \\
200 \mathrm{~g} \mathrm{~d}^{-1} \\
200 \mathrm{~g} \mathrm{~d}^{-1}\end{array}$ & $\begin{array}{l}\mathrm{NA}^{b} \\
\mathrm{NA} \\
\mathrm{NA}\end{array}$ \\
\hline Soil ingestion & $0.1 \mathrm{~g} \mathrm{~d}^{-1}$ & $0.01 \mathrm{~g} \mathrm{~d}^{-1}$ \\
\hline Inhalation & $23 \mathrm{~m}^{3} \mathrm{~d}^{-1 c}$ & NA \\
\hline $\begin{array}{l}\text { External exposure } \\
\text { Irrigated soil } \\
\text { Dredged sediment }\end{array}$ & $\begin{array}{l}1000 \mathrm{~h} \mathrm{y}^{-1} \\
1000 \mathrm{~h} \mathrm{y}^{-1}\end{array}$ & $\begin{array}{l}100 \mathrm{~h} \mathrm{y}^{-1} \\
\text { NA }\end{array}$ \\
\hline
\end{tabular}

${ }^{a} \mathrm{~A} 0.5$ concentration reduction factor is used to account for consumption of fluids originating outside the region of contamination (NCRP 1984, Yang and Nelson 1984, Rupp 1980, Rupp et al. 1980, USEPA 1989b).

${ }^{b} \mathrm{NA}=$ not applicable for scenario considered.

${ }^{c} \mathrm{~A}$ concentration reduction factor of 0.5 is used to account for time spent indoors or outside the region of contamination. 


\subsubsection{Criteria for Conscrvative Screening}

Noncarcinogens with total screening indices <0.1, or carcinogens with total screening indices $<10^{6}$, are designated through conservative screening as definitely low priority contaminants. Contaminants with noncarcinogen screening indices $>1.0$ or those with carcinogen screening indices $>10^{-3}$ are designated as potentially high priority for further evaluation and possible remedial action (Table 2.3). All contaminants not designated as definitely low priority substances are considered contaminants of concern subject to further evaluation.

\subsubsection{Screening Indices for Carcinogens and Noncarcinogens}

Screening indices (SIs) for carcinogens and noncarcinogens are calculated for contaminants of potential concern to human health. The screening index for carcinogens is a conservative estimate of exposure of the contaminant via ingestion or inhalation multiplied by an EPA-approved or -suggested "slope factor" for nonradioactive substances to indicate the potential lifetime risk of excess cancer (Appendix A). The slope factor provides an estimate of the lifetime risk of additional cancer incidence per unit exposure. For radioactive materials, exposure is transiated into units of effective dose equivalent using factors of dose per unit intake or area deposition recommended for screening (NCRP in press) and multiplied by a weighted cancer incidence risk conversion factor of $5.7 \times 10^{-2}$ per Sievert based on the 1988 report of the United Nations Scientific Committee on the Effects of Atomic Radiation (UNSCEAR 1988, Stather et al. 1988, Clarke 1988)2

The screening index for noncarcinogens is a ratio that is composed of a conservatively biased estimate of ingestion or inhalation of the contaminant divided by a "reference dose (RfD) factor" (Appendix A). The reference dose is an EPA-approved noncarcinogenic contaminant exposure level below which adverse effects should not occur.

To be consistent with EPA recommendations for risk assessment (USEPA 1989a), screening indices for each contaminant are summed over all contaminants in a given pathway. For estimation of potential exposure to multiple pathways, screening indices are summed across pathways for each contaminant. Summation is conducted separately for carcinogens and noncarcinogens.

\subsection{NONCONSERVATTVE SCREENING}

The objective of nonconservative screening calculations is to rapidly identify contaminants and exposure pathways having the highest priority for further evaluation

${ }^{2}$ Since the completion of these screening calculations, interim radionuclide slope factors have become available from EPA (USEPA 1989d). A comparison has concluded that general agreement would be attained if the effective dose-equivalent and risk conversion factor used in this report were to be replaced with the EPA slope factor. 


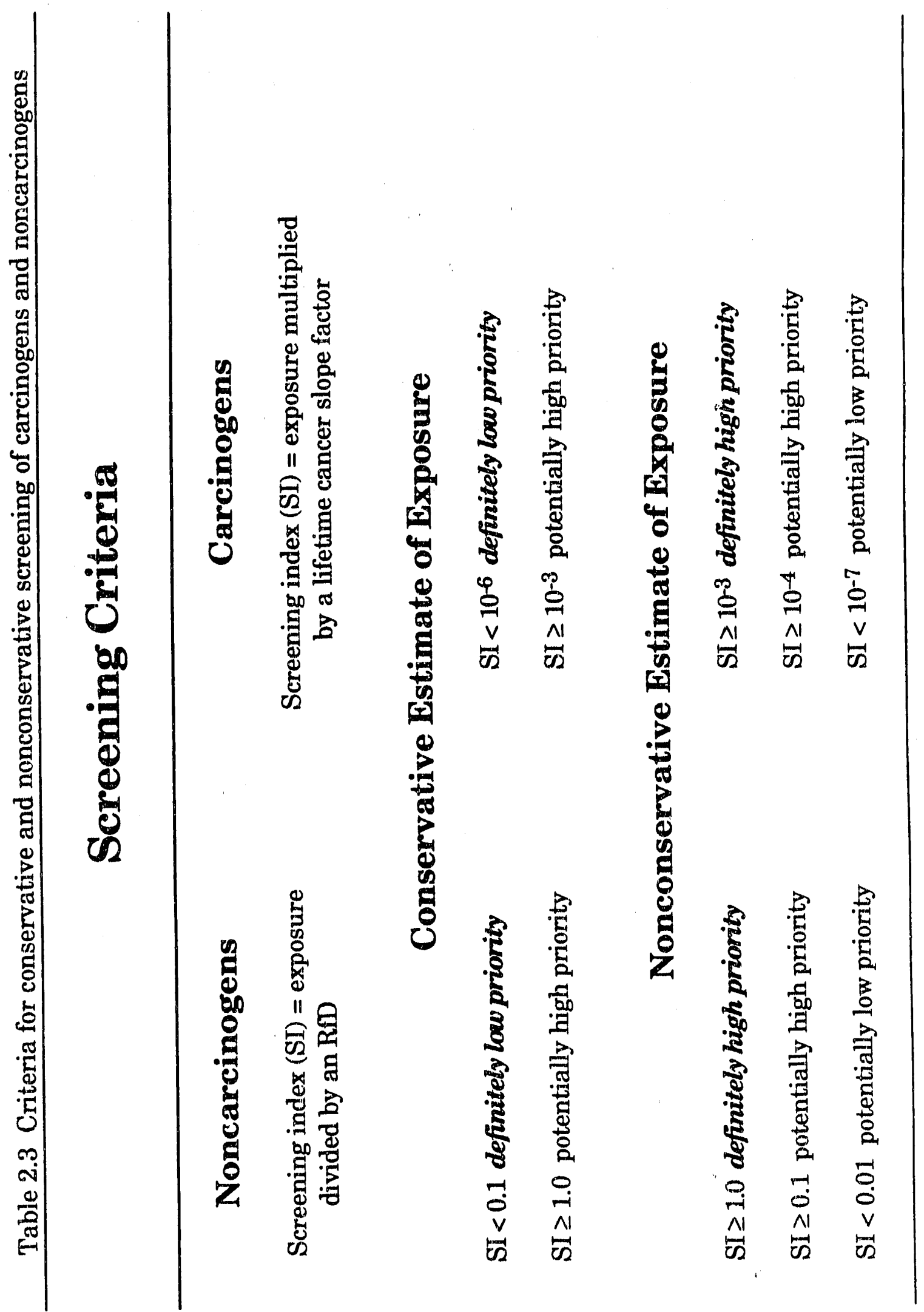


and/or remedial action consideration. Once a contaminant is assigned a definite high priority, an immediate review of the source data base and health advisory criteria should be conducted, including a review of the data used to derive EPA RfDs and carcinogen slope factors. These reviews may establish the need for immediate implementation of an interim remediation effort.

For nonconservative screening, average values of concentrations of contaminants in sediment, water, and fish are used. These concentrations, however, are averaged only among values reported above the limits of detection. Dietary habits and occupancy factors for potential receptors are based on assumed casual use of the medium of concern (Table 2.2). Multiple exposures to different contaminated media by the same individual are not considered; thus calculated screening indices for carcinogens and noncarcinogens are not summed across pathways. This approach is not likely to produce a large overestimate of potential maximum exposure, provided that fish, water, and sediment are actually utilized at the location of interest. Under some circumstances, nonconservative screening may underestimate maximum exposures to humans who are actually utilizing the Clinch River environment.

\subsection{Exposure Pathways for Nonconservative Screening}

The exposure pathways considered for nonconservative screening are only those for which concentrations above the limits of detection have been measured and reported. Exposure pathways are those limited to the ingestion of fish, water, and sediment as well as the external exposure from gamma radiation emitted from radioactive deposits in sediment. Models were not used to estimate concentrations in media that were not sampled, and models were not used to estimate concentrations of contaminants analyzed for and not detected.

\subsubsection{Screening Indices for Carcinogens and Noncarcinogens}

The screening indices for nonconservative screening are similar to those for conservative screening. For carcinogens, an estimate of exposure is multiplied by an EPA slope factor (or $5.7 \times 10^{-2}$ per Sievert for radionuclides) to indicate the risk of excess cancer incidence during a 70-year lifetime. For noncarcinogens, an estimate of exposure is divided by an EPA-approved RfD (Appendix A). These slope factors and RfDs may themselves contain a large amount of conservatism in their derivation; therefore, detailed reevaluation of their derivation is warranted when nonconservative screening designates a contaminant as a high-priority substance.

\subsubsection{Criteria for Nonconservative Screening}

For nonconservative screening, contaminants that have noncarcinogen screening indices exceeding 1.0 or carcinogen screening indices exceeding $10^{-3}$ are designated as definitely high priority for remedial action consideration. Contaminants that have noncarcinogen screening indices exceeding 0.1 or carcinogen screening indices exceeding 
$10^{-4}$ are designated as potentially high priority substances. Because of the absence of conservatism in the exposure calculations, contaminants are only designated as potentially low priority substances when noncarcinogen screening indices are $<0.01$ or carcinogen screening indices are $<10^{.7}$ (Table 2.3 ). 


\section{DESCRIPTION OF SURFACE WATER REACHES AND DEVELOPMENT OF SOURCE TERM DATA BASE}

\subsection{RIVER AND STREAM REACHES}

The Clinch River off-site area to be investigated in CRRFI was divided into units or reaches based upon the proximity to known contaminant release points from DOE facilities and other potential sources of pollution. These stream and river reaches are shown in Figs. 3.1 and 3.2. A description of the reaches and reach boundaries and the facilities releasing effluents that eventually enter a particular reach are given in Table 3.1.

Effluents containing contaminants from the Oak Ridge facilities (ORNL, Y-12, and ORGDP) are released into East Fork Poplar Creek, Bear Creek, Poplar Creek, White Oak Creek, and the Clinch River. Melton Hill Reservoir, Reach 1, receives effluents from Y-12's fly ash pond via McCoy Branch and from a waste disposal site in Kerr Hollow via Scarboro embayment. Effluents from ORNL and associated waste management sites enter streams that drain White Oak Creek watershed and are transported downstream to White Oak Lake where DOE's control of the effluents is lost at White Oak Dam. Contaminants from ORNL are associated primarily with Reach 2 and downstream reaches. Effluents from Y-12 and associated facilities are released into Bear Creek and East Fork Poplar Creek, both of which will be subject to separate RCRA facility investigations (RFIs). For purposes of CRRFI, the first surface water reach potentially affected by Y-12 plant effluents begins at the confluence of East Fork Poplar Creek with Poplar Creek (Reach 3). Effluents from ORGDP are also released into Poplar Creek (Reach 3) and the Clinch River above and below the confluence of Poplar Creek, Reaches 2 and 4, respectively. Three reaches were used in the screening analyses as references reaches: Norris Reservoir (Reach 10), Poplar Creek above the confluence of East Fork Poplar Creek (Reach 13), and the Tennessee River from the confluence with the Clinch River to Fort Loudoun Dam (Reach 18). Reference reaches do not receive effluents from DOE Oak Ridge facilities; however, they may be recipients of industrial wastes from other sources. Based on the data available, Norris Reservoir (Reach 10) appears to be the least polluted of the reference reaches.

\subsection{SOURCES OF INFORMATION}

Information used in the screening analyses included a compilation of existing data from previous monitoring programs, surveys, and scientific studies. The information was evaluated for its relevance to a screening analysis, and data for three environmental media (water, fish, and sediment) were compiled into a data base. The data base used for screening included approximately 9,000 values for contaminants in sediment, 9,000 for fish, and 25,000 for water. Many of these were organic chemicals that were below the limits of detection. These data were summarized to obtain source terms for the environmental pathway models to predict the exposure of hurnans and biota to contaminants. The source term data consisted of maximum and mean concentrations of organic and inorganic (melals) compounds and radionuclides in the three environmental media. Sources of the information for the different environmental media are listed in Table 3.2. Screening of these data is necessary to determine sampling priorities and to focus the efforts of the base-line risk analysis. 


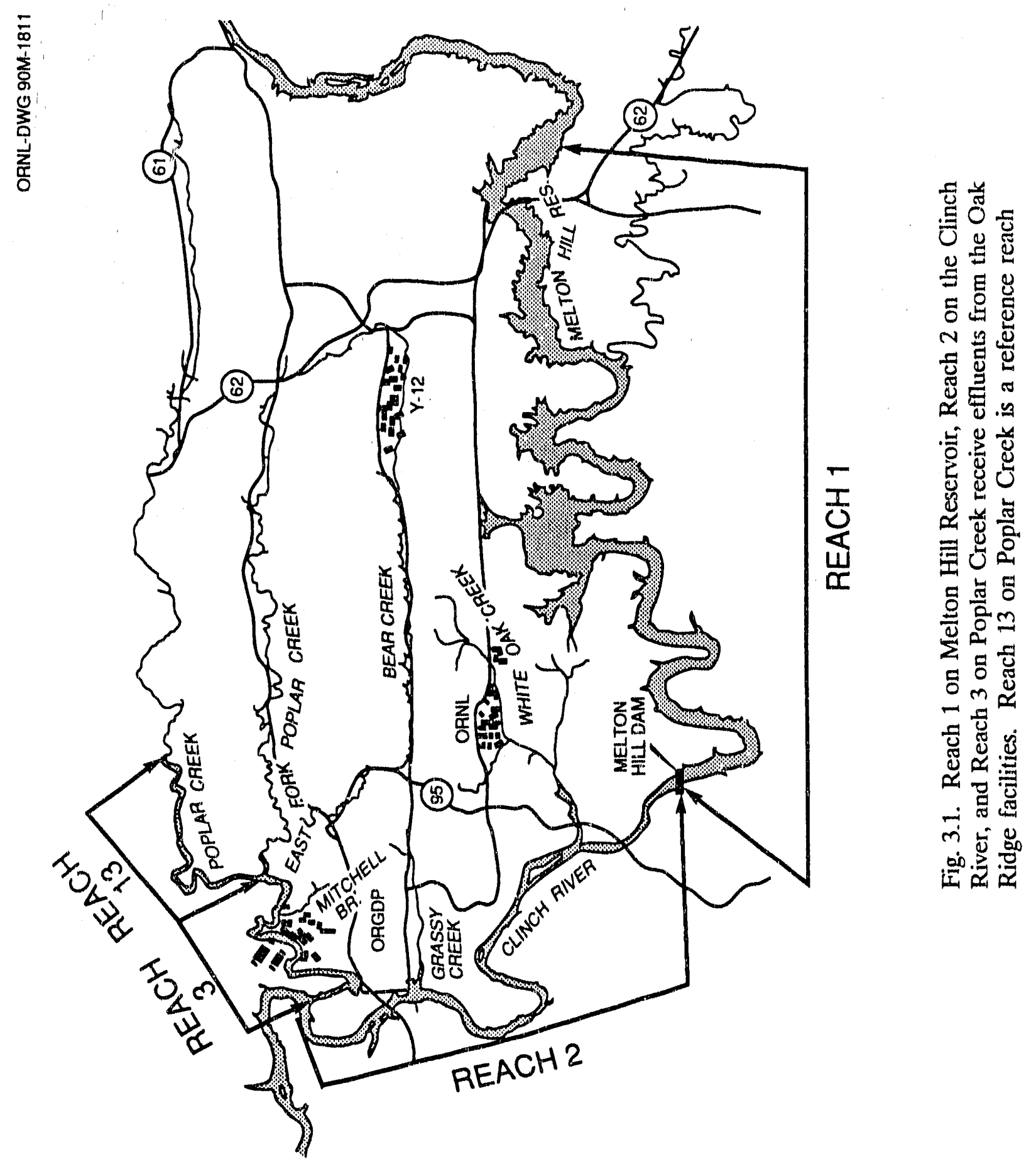




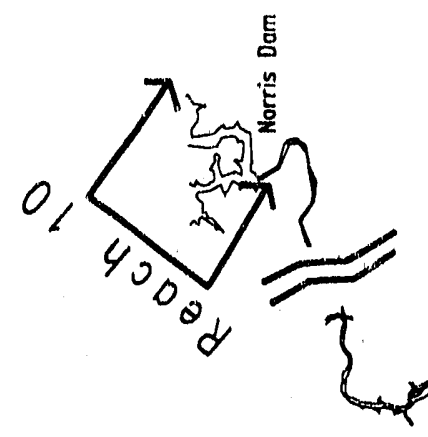

स
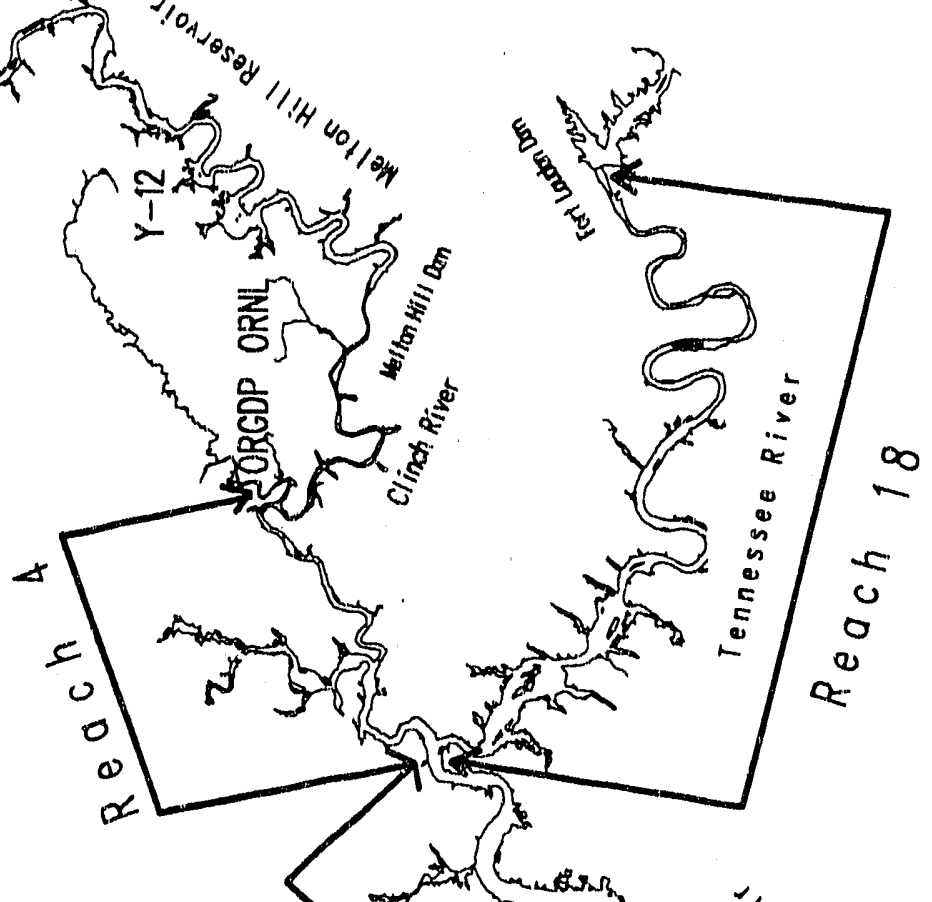

3

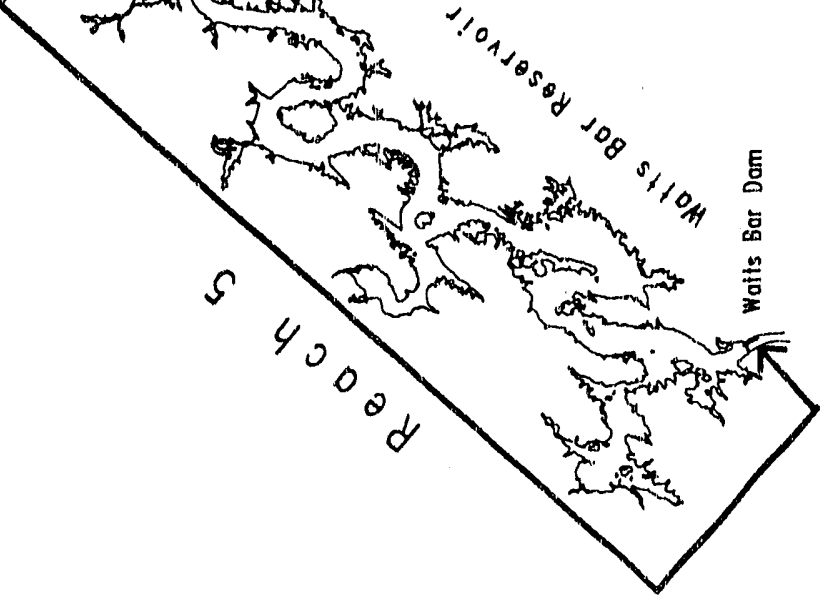

券皆

늘

통

톨를

ᄋํำ

选

茫

导

过

必

击

ต

몰

3

ज苞

뎡 근

\&

ํㅡㅇ

苞

\&

.

년

氖怘完

0 D

U

들

등 든

$\forall$ 당

뉼 吨 ن $\stackrel{\infty}{2}$ ले

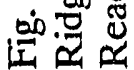


Table 3.1. River and stream reaches and associated facilitics to be evaluated in the Clinch River RCRA Facility Investigation

\begin{tabular}{|c|c|c|}
\hline $\begin{array}{l}\text { Reach } \\
\text { number }\end{array}$ & $\begin{array}{l}\text { Reach name (description) } \\
\text { and associated facilities }\end{array}$ & $\begin{array}{l}\text { River or } \\
\text { stream mile }\end{array}$ \\
\hline 1 & Melton Hill Reservoir (Y-12) & $\begin{array}{l}\mathrm{CRM}^{a} \\
23.1-42.0\end{array}$ \\
\hline 2 & $\begin{array}{l}\text { Clinch River from Poplar Creek } \\
\text { confluence to Melton Hill Dam } \\
\text { (includes White Oak } \\
\text { Creek embayment) (ORNL and Y-12) }\end{array}$ & $\begin{array}{l}\text { CRM } \\
12.5-23.1\end{array}$ \\
\hline 3 & $\begin{array}{l}\text { Poplar Creek from mouth to } \\
\text { confluence with East Fork } \\
\text { Poplar Creek (ORGDP and Y-12) }\end{array}$ & $\begin{array}{l}\text { PCM } \\
0.0-5.4\end{array}$ \\
\hline 4 & $\begin{array}{l}\text { Clinch River from mouth to confluence } \\
\text { with Poplar Creek (ORNL, Y-12, and ORGDP) }\end{array}$ & $\begin{array}{l}\text { CRM } \\
0.0-12.0\end{array}$ \\
\hline 5 & $\begin{array}{l}\text { Watts Bar Reservoir from Watts Bar Dam } \\
\text { to confluence with Clinch River } \\
\text { (ORNL, Y-12, and ORGDP) }\end{array}$ & $\begin{array}{l}\text { TRM } \\
529.9-567.8\end{array}$ \\
\hline 10 & Norris Reservoir (reference reach) & $\begin{array}{l}\text { CRM } \\
79.8-88.8\end{array}$ \\
\hline 13 & $\begin{array}{l}\text { Poplar Creek above confluence with } \\
\text { East Fork Poplar Creek (reference reach) }\end{array}$ & $\begin{array}{l}\text { PCM } \\
5.4-13.0\end{array}$ \\
\hline 18 & $\begin{array}{l}\text { Tennessee River from confluence with } \\
\text { Clinch River to Fort Loudon Dam } \\
\text { (reference reach) }\end{array}$ & $\begin{array}{l}\text { TRM } \\
567.8-602.3\end{array}$ \\
\hline
\end{tabular}

${ }^{a} \mathrm{CRM}=$ Clinch River mile, $\mathrm{PCM}=$ Poplar Creek mile, TRM = Tennessee River mile. 
Table 3.2. Sources of data on contaminant concentrations in fish, water, and sediment in off-site surface water used to develop a data base for screening analyses

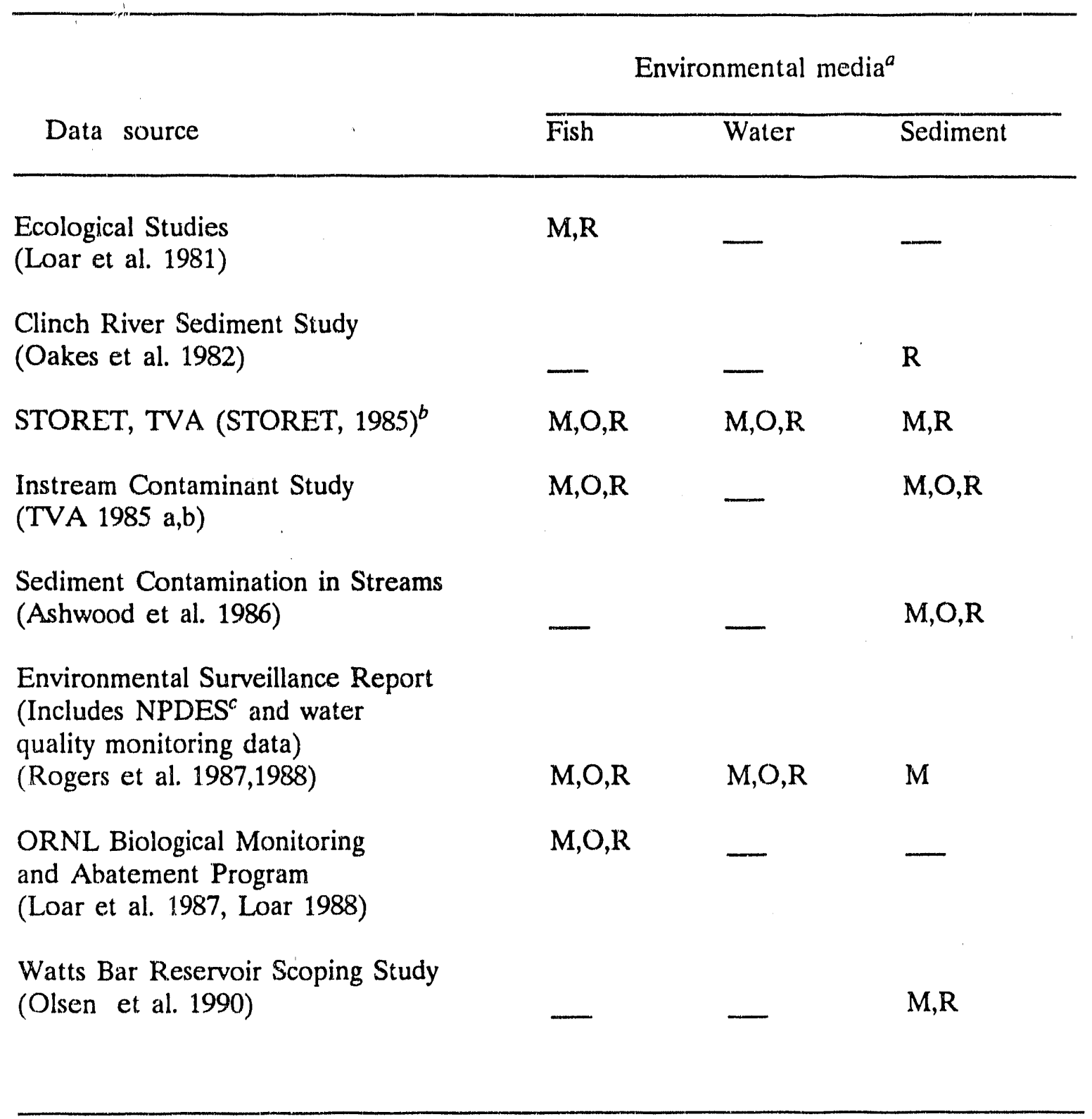

$$
\begin{aligned}
& { }^{a} \mathrm{M}=\text { metals } \\
& \mathrm{O}=\text { organic, } \\
& \mathrm{R}=\text { radionuclides }
\end{aligned}
$$

${ }^{b}$ STORET 1985 (TVA data from 1982-1989).

${ }^{c}$ NPDES $=$ National Pollution Discharge Elimination System. 


\subsection{DATA SUMMARIES}

The data summaries developed for the screening analyses are given in tables in Appendix B. The maximum and mean values for concentrations of organics, inorganics, and radionuclides are given for fish, water, and sediment for each river and stream reach. Maximum values consisted of either the maximum measured contaminant concentrations that exceeded the limits of detection or the limits of detection for contaminants that were analyzed for but not detected. Mean values consisted of the means of measured values greater than the limits of detection. Mean values for sediment were for surface-sediment samples only. The maximum and mean concentrations for organic contaminants in sediment, fish, and water for each stream or river reach are listed in Tables B1 and B2, respectively. Maximum and mean concentrations for inorganics (metals) in sediment, fish, and water for each stream or river reach are in Tables B3 and B4, respectively. Maximum and mean values for radionuclides are listed in Tables B5 and B6, respectively.

Environmental media were analyzed for many contaminants that were not detected. These data are analyzed in Appendix E. Table E1 lists the minimum detection limits reported for inorganic compounds from all reaches for sediment, fish, and water. The minimum detection limits reported for organics are given in Table E2 and for radionuclides in Table E3. 


\section{RESULTS}

The complete results obtained from conservative and nonconservative screening are reported in Appendixes $C$ and $D$, respectively. Fifteen inorganic chernicals, 16 organic chemicals, and 11 radionuclides were identified as potentially high priority contaminants of concern in one or more reaches of the Clinch River environment. Of these, arsenic in the water of Reach 1, thallium in fish of Reach 1 , and ${ }^{137} \mathrm{Cs}$ in the sediment of Reach 2 have been identified as definitely high priority substances.

Because of the use of maximum reported concentrations and cancer screening limits of $10^{-6}$ for carcinogens and 0.1 for noncarcinogens, few substances were identified through conservative screening as definitely low priority substances. Most contaminants listed as definitely low priority substances were classified assuming that dredging of sediment would not occur. No reach was identified as either a definitely or potentially low priority.

The conservative practice [as recommended by EPA (USEPA 1989a)] of summing screening indices for carcinogen and noncarcinogen contaminants did not result in a substantial difference between the total screening index for a given reach summed over all contaminants (Appendix C: Tables $\mathrm{Cla}$ and $\mathrm{b}$, and Tables C5a and b; Appendix D: Tables D1 and D2) and the maximum index for a specific contaminant (Appendix C: Tables C2a through $\mathrm{C} 4 \mathrm{~b}$, and Tables $\mathrm{C} 6 \mathrm{a}$ and $\mathrm{C} 7 \mathrm{~b}$; and Appendix D: "iables D3 through D7). In all but two cases, this difference was well within a factor of 3 with the majority being within a factor of 2 . The largest difference, a factor of 5 , occurred for assumed dredging of sediment at Reach 3.

The screening indices reported in Appendices $C$ and $D$ are based on health risk end points. Nevertheless, these results should not be equated with those of a base-line human health risk assessment. The indices produced through conservative screening are intended not to underestimate potential maximum exposures, and thus they may be a gross overestimation of actual exposures. The indices produced through nonconservative screening are intended not to overestimate potential maximum exposures, and thus are lower than would be produced using recommended EPA risk assessment procedures (USEPA 1989a) for estimating maximum exposures.

The following sections summarize the results obtained through nonconservative and conservative screening. Because of the importance of nonconservative screening in identifying definitely high and potentially high priority contaminants, these results are presented first.

\subsection{HIGH-PRIORITY CONTAMINANTS IDENTIFIED THROUGH NONCONSERVATTVE SCREENING}

Nonconservative screening has identified definitely high priority contaminants in Reaches 1 and 2 and potentially high priority contaminants in Reaches 1 through 5 (Figs. 4.1A and 4.1B, and Table 4.1). Within these reaches, a total of 10 contaminants (i.e., 4 inorganic chemicals, 3 organic chemicals, and 3 radionuclides) have been identified as 
A. Carcinogens

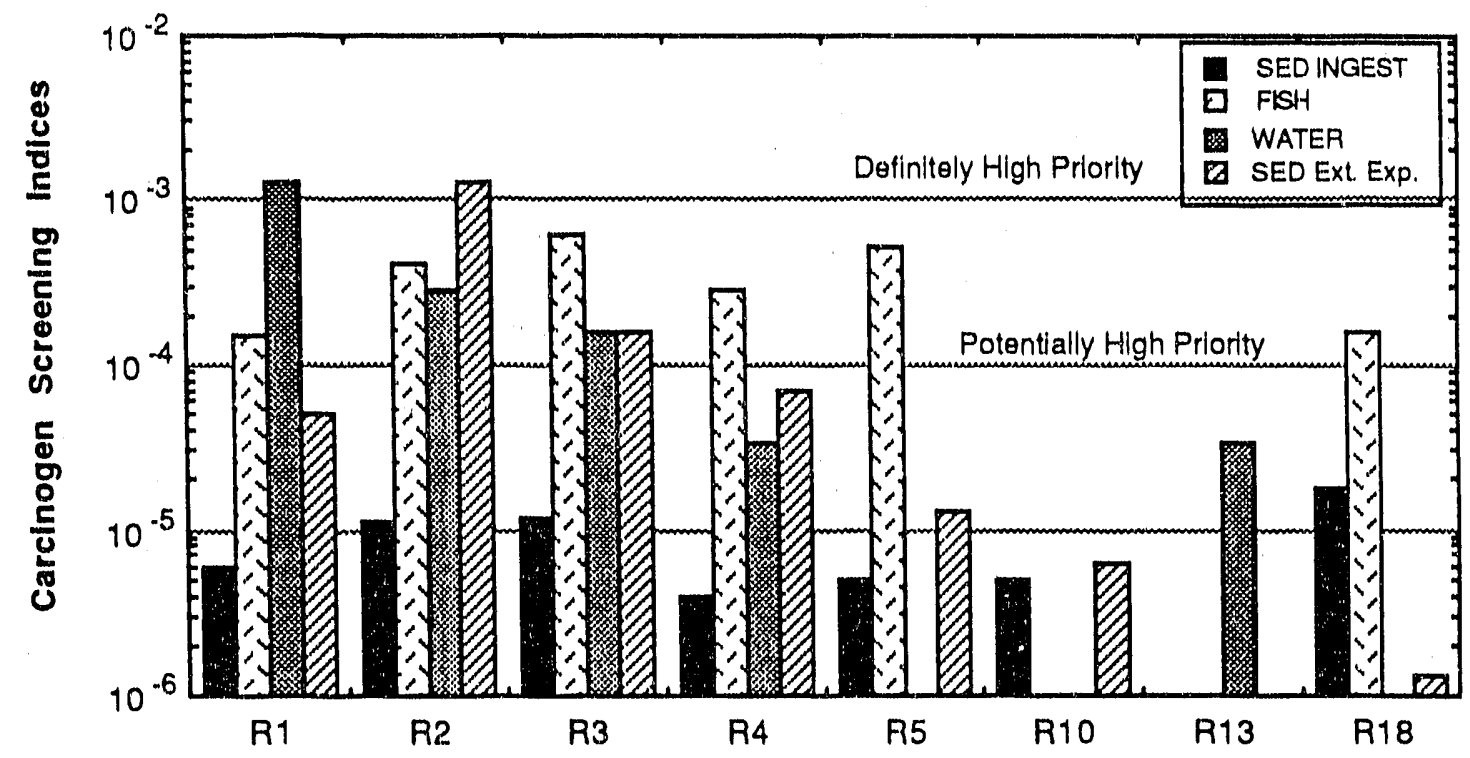

B. Non-carcinogens

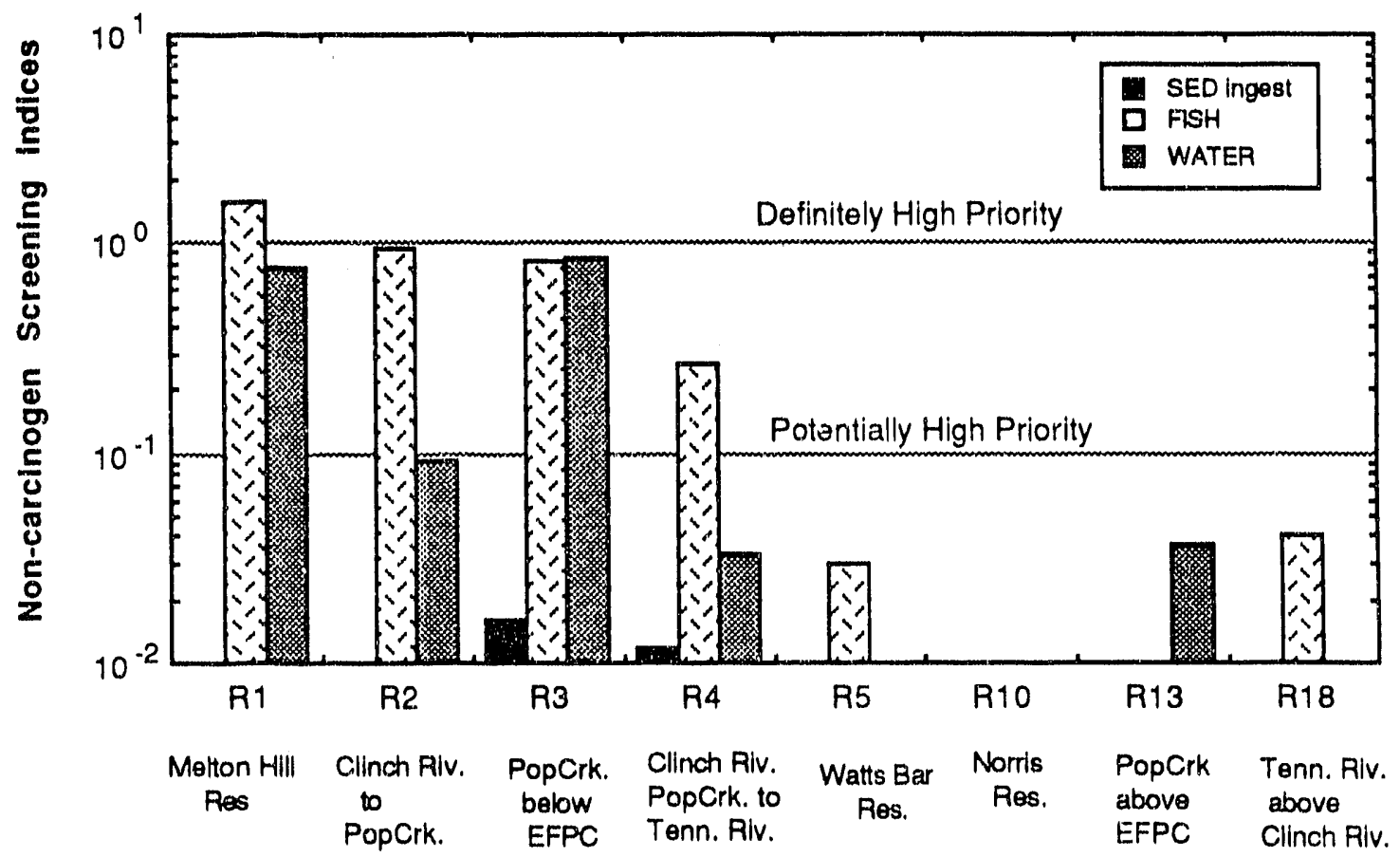

Fig. 4.1. A comparison of pathway totalled screening indices by reach for carcinogens (Fig. 4.1A) and non-carcinogens (Fig. 4.1B) using nonconservative estimates of exposure. 
Table 4.1. Contaminants assigned either a definitely or potentially high priority through nonconservative screening

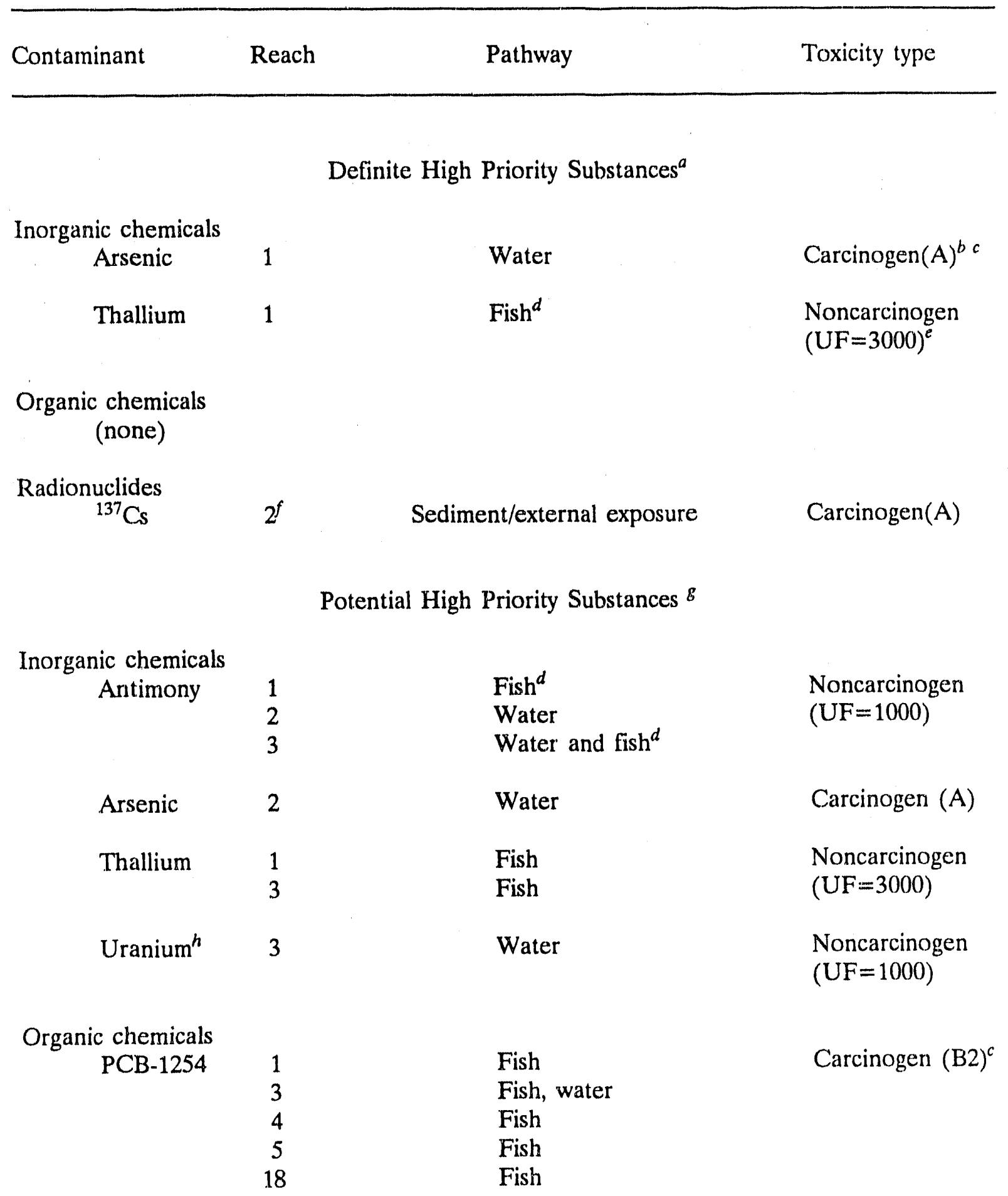


Table 4.1 (continucd)

\begin{tabular}{cccc}
\hline Contaminant & Reach & Pathway & Toxicity type \\
\hline Organic chemicals (continued) & & \\
PCB-1260 & 1 & Fish & Carcinogen (B2) \\
& 3 & Fish & \\
& 4 & Fish & \\
${ }^{C h l o r c l a n e}$ & 1 & Fish & Noncarcinogen \\
& 2 & Fish & (UF=100)) \\
Radionuclides & 4 & Fish & \\
${ }^{137} \mathrm{Cs}$ & $2^{i}$ & Fish & Carcinogen (A) \\
& 4 & Sediment/external exposure & \\
${ }^{3} \mathrm{H}$ & 2 & Sediment/external exposure & Carcinogen (A) \\
${ }^{60} \mathrm{Co}$ & 2 & Water & Carcinogen (A) \\
${ }^{234} \mathrm{~Pa}$ & 3 & Sediment/external exposure & Carcinogen (A) \\
${ }^{90} \mathrm{Sr}$ & 2 & Sediment/external exposure & Carcinogen (A) \\
${ }^{152} \mathrm{Eu}$ & 2 & Warcinogen (A) \\
${ }^{154} \mathrm{Eu}$ & 2 & Sediment/external exposure & Carcinogen (A) \\
\hline
\end{tabular}

${ }^{a}$ Carcinogen screening index $\geq 10^{-3} ;$ noncarcinogen screening index $\geq 1.0$.

${ }^{b}$ Under EPA review.

${ }^{c} \mathrm{~A}=$ sufficient human evidence for carcinogenicity,

$\mathrm{B} 2$ = sufficient evidence in animals but none or inadequate data for humans.

${ }^{d}$ Potential artifact, few positive samples reported.

${ }^{e} \mathrm{UF}=$ uncertainty factor used by EPA to derive a RID for noncarcinogens.

${ }^{f}$ Averaged for six samples taken in White Oak Lake embayment (public access not permitted, posted area).

${ }^{8}$ Carcinogen screening index $\geq 10^{-4}$; noncarcinogen screening index $\geq 0.1$.

${ }^{h}$ Assumed as uranium salt.

${ }^{i}$ Averaged for 32 surface sediment samples taken throughout Reach 2. 
either definitely or potentially high priority. Of these, arsenic in water samples from each 1 and ${ }^{137} \mathrm{Cs}$ in sediment at Reach 2 have been classified as definitely high priority contaminants. Both of these contaminants are designated as Group A carcinogens by EPA, meaning that sufficient human data support classification as a carcinogen. Thallium in fish of Reach 1 is also classified as a definitely high priority contaminant, but this classification may be an artifact given that only 4 of 26 samples were reported at or above the limit of detection. Thallium is a noncarcinogen; large safety factor $(U F=3000)$ was applied to account for uncertainty in the derivation of its RfD by EPA (USEPA 1989d).

It is likely that the nonconservative calculation of exposure to arsenic in water at Reach 1 (Appendix D) is an overestimate of actual exposures. Arsenic concentrations on which the exposure estimates were based were derived from samples obtained from the National Pollution Discharge Elimination System (NPDES) station located on the ORR below Roger's Quarry on McCoy Branch, a small stream entering the Clinch River at river mile 37.6. Water at that losation is not presently used for drinking, and dilution in the Clinch River is considerable. Arsenic concentrations near water intakes for treatment facilities downstream from this reach are much lower (by approximately one order of magnitude), and treatment processes should effectively remove such chemicals from the water prior to human consumption.

The external exposure to sediments containing ${ }^{137} \mathrm{Cs}$ in Reach 2 is also a likely overestimate because the high sediment concentrations are located in the embayment of White Oak Creek downstream from White Oak Lake. This is a posted area and public access is restricted. Potentially high priority screening indices $\left(\sim 10^{-4}\right)$ could also occur in Reach 2 from external gamma radiation frem ${ }^{137} \mathrm{Cs}$ in the 0800 Area of the Oak Ridge Reservation at Clinch River mile 20.5 (Fritzsche 1987, Rogers et al. 1989a). This stretch of river is not restricted to public access, although the source of radioactivity is on land within a secured area adjacent to the river.

Further analyses of samples from these reaches and more accurate assessments of the potential risk of exposure via all possible pathways is warranted to guide decisions about remedial action alternatives. Risk estimates may be revised in either direction as a result of a more detailed investigation that would take into account additional pathways of exposure and more realistic assumptions about the potential for individuals to be maximally exposed (USEPA 1989a).

\subsection{POTENTIALLY HIGH PRIORITY CONTAMINANTS IDENIIFIED THROUGH CONSERVATTVE SCREENING}

The use of maximum reported concentrations in water, fish, or sediment as well as the application of conservatively biased model calculations to estimate exposures resulting from possible irrigation and sediment dredging produce a much larger listing of potentially high priority contaminants than was produced with nonconservative screening (Table 4.2). The majority of the potentially high priority contaminants are located in those reaches subjected to the most frequent sampling, namely Reaches 1, 2, 3, 4 and 5. Among these reaches, Reach 3 contains the most contaminants of potentially high priority, of which 13 are inorganic chemicals, 16 are organic chemicals, and 11 are radionuclides. Most of the radionuclides of potentially high priority are found in Reach 2, which is to be expected

because of releases from waste management areas surrounding Oak Ridge National 
Table 4.2. Contaminants assigned a potentially high priority through conservative screening

\begin{tabular}{|c|c|c|c|}
\hline Contaminant & Reach & Pathway & Toxicity type \\
\hline $\begin{array}{c}\text { Inorganic chemical } \\
\text { Arsenic }\end{array}$ & $\begin{array}{c}1 \\
2 \\
3 \\
4 \\
5 \\
10 \\
13 \\
18\end{array}$ & $\begin{array}{c}\text { Water, } \operatorname{veg}\left(I^{b}\right), \operatorname{veg}\left(D^{c}\right) \\
\text { Water, } \operatorname{veg}(I), \operatorname{soil} / \text { ing }(I), \operatorname{veg}(D) \\
\text { Water, } \operatorname{veg}(I), \operatorname{veg}(D) \\
\operatorname{Veg}(D) \\
\operatorname{Veg}(D) \\
\operatorname{Veg}(D) \\
\operatorname{Veg}(D), \operatorname{fish}, \\
\operatorname{Veg}(D)\end{array}$ & $\begin{array}{l}\text { Carcinogen }(\mathrm{A})^{d e} \\
\text { and } \\
\text { noncarcinogen } \\
(\mathrm{UF}=1)\end{array}$ \\
\hline Antimony & $\begin{array}{l}1 \\
2 \\
3\end{array}$ & $\begin{array}{c}\text { Fish } \\
\text { Fish, veg (I) } \\
\text { Fish, water, meat }(\mathrm{I}), \operatorname{veg}(\mathrm{I}), \text { soil/ing }(\mathrm{I}) \text {, veg(!) } \\
\text { meat (D) }\end{array}$ & $\begin{array}{l}\text { Noncarcinogen } \\
(\mathrm{UF}=1000)^{f} \\
\mathrm{D})\end{array}$ \\
\hline Barium & 4 & Water,veg(I),veg(D) & $\begin{array}{l}\text { Noncarcinogen } \\
(\mathrm{UF}=100)\end{array}$ \\
\hline Beryllium & $\begin{array}{l}1 \\
2 \\
3 \\
4 \\
5\end{array}$ & $\begin{array}{l}\operatorname{Veg}(D) \\
\operatorname{Veg}(D), \text { meat}(D) \\
\operatorname{Veg}(D), \text { meat(D) } \\
\operatorname{Veg}(D) \\
\operatorname{Veg}(D)\end{array}$ & Carcinogen(B2) \\
\hline Boron & $\begin{array}{l}3 \\
4\end{array}$ & $\begin{array}{l}\text { Water, meat(I), milk(I), veg(I), veg(D), } \\
\text { milk(D) } \\
\text { Water, milk(I), meat(I), veg(I), veg(D), } \\
\text { milk(D) }\end{array}$ & $\begin{array}{l}\text { Noncarcinogen } \\
(\mathrm{UF}=100)\end{array}$ \\
\hline Cadmium & $\begin{array}{l}2 \\
3 \\
4\end{array}$ & $\begin{array}{c}\operatorname{Veg}(D), \operatorname{milk}(D) \\
\text { Water, } \operatorname{milk}(I), \operatorname{veg}(I), \operatorname{veg}(D), \operatorname{milk}(D) \\
\operatorname{Veg}(D)\end{array}$ & $\begin{array}{l}\text { Noncarcinogen } \\
(\mathrm{UF}=10)\end{array}$ \\
\hline
\end{tabular}


Table 4.2 (continued)

\begin{tabular}{|c|c|c|c|}
\hline Contaminant & Reach & Pathway & Toxicity type \\
\hline \multicolumn{4}{|c|}{ Inorganic chemicals (continued) } \\
\hline Chromium ${ }^{g}$ & 1 & $\operatorname{Veg}(\mathrm{D})$, meat $(\mathrm{D})$ & \multirow{7}{*}{$\begin{array}{l}\text { Noncarcinogen } \\
(\mathrm{UF}=500)\end{array}$} \\
\hline & 2 & $\operatorname{Veg}(\mathrm{D}), \operatorname{milk}(\mathrm{D})$, meat(D) & \\
\hline & 3 & $\operatorname{Veg}(\mathrm{D})$, milk(D), meat(D) & \\
\hline & 4 & Meat (I), $\operatorname{veg}(\mathrm{D})$, milk(D), meat(D) & \\
\hline & 5 & $\operatorname{Veg}(\mathrm{D}), \operatorname{milk}(\mathrm{D})$, meat(D) & \\
\hline & 10 & Meat (D) & \\
\hline & 18 & $\operatorname{Veg}(\mathrm{D}), \operatorname{milk}(\mathrm{D}), \operatorname{meat}(\mathrm{D})$ & \\
\hline \multirow[t]{5}{*}{ Mercury } & 1 & Fish, veg(I), meat (I) & \multirow{5}{*}{$\begin{array}{l}\text { Noncarcinogen } \\
(\mathrm{UF}=10)\end{array}$} \\
\hline & 3 & Fish, veg(D), milk(D), meat(D) & \\
\hline & 4 & Fish, $\operatorname{veg}(\mathrm{D}), \operatorname{milk}(\mathrm{D})$, meat(D) & \\
\hline & 5 & $\operatorname{Veg}(\mathrm{D})$, milk(D), meat(D) & \\
\hline & 18 & $\operatorname{Veg}(D)$, milk(D), meat(D) & \\
\hline \multirow[t]{3}{*}{ Nickel } & 3 & Water, $\operatorname{veg}(\mathrm{I}), \operatorname{veg}(\mathrm{D}), \operatorname{milk}(\mathrm{D})$, meat(D) & \multirow{3}{*}{$\begin{array}{l}\text { Noncarcinogen } \\
(\mathrm{UF}=300)\end{array}$} \\
\hline & 4 & $\operatorname{Veg}(\mathrm{D})$ & \\
\hline & 13 & $\operatorname{Veg}(D)$ & \\
\hline \multirow[t]{5}{*}{ Selenium } & 1 & Milk (I), meat(I), meat(D) & \multirow{5}{*}{$\begin{array}{l}\text { Noncarcinogen } \\
(\mathrm{UF}=15)\end{array}$} \\
\hline & 2 & Meat(I), veg(D), milk(D), meat(D) & \\
\hline & 3 & $\operatorname{Veg}(\mathrm{D})$, milk(D), meat(D),soil/ing(D) & \\
\hline & 4 & Meat(I), veg(D), milk(D), meat(D) & \\
\hline & 5 & Meat(I), meat (D) & \\
\hline \multirow[t]{3}{*}{ Silver } & 2 & $\operatorname{Veg}(D)$, milk(D), meat(D) & \multirow{3}{*}{$\begin{array}{l}\text { Noncarcinogen } \\
(\mathrm{UF}=2)\end{array}$} \\
\hline & 3 & Milk(I), milk(D) & \\
\hline & 4 & $\operatorname{Veg}(\mathrm{D}), \operatorname{milk}(\mathrm{D})$ & \\
\hline \multirow[t]{3}{*}{ Thallium } & 1 & Fish, veg(D), milk(D), meat(D) & \multirow{3}{*}{$\begin{array}{l}\text { Noncarcinogen } \\
(\mathrm{UF}=3000)\end{array}$} \\
\hline & 2 & Fish, veg(D), milk(D), meat(D) & \\
\hline & 3 & Fish, veg(D), milk(D), meat(D) & \\
\hline \multirow[t]{2}{*}{ Uranium $^{h}$} & 2 & $\operatorname{Veg}(D)$ & \multirow{2}{*}{$\begin{array}{l}\text { Noncarcinogen } \\
(\mathrm{UF}=1000)\end{array}$} \\
\hline & 3 & $\begin{array}{l}\text { Fish, water, meat(I), milk(I), veg(I), } \\
\text { soil/ing(I), } \operatorname{Veg}(D), \\
\text { milk(D), meat(D) }\end{array}$ & \\
\hline Vanadium $^{i}$ & 4 & Fish, veg(D), meat(D) & $\begin{array}{l}\text { Noncarcinogen } \\
(\mathrm{UF}=100)\end{array}$ \\
\hline
\end{tabular}


Table 4.2 (continued)

\begin{tabular}{|c|c|c|c|}
\hline Contaminant & Reach & Pathway & Toxicity type \\
\hline \multicolumn{4}{|c|}{ Inorganic chemicals (continued) } \\
\hline Zinc & 1 & $\operatorname{Veg}(\mathrm{D})$, milk(D), meat(D) & Noncarcinogen \\
\hline & 2 & $\operatorname{Veg}(\mathrm{D})$, milk(D), meat(D) & $(\mathrm{UF}=10)$ \\
\hline & 3 & Meat $(I), \operatorname{veg}(D), \operatorname{milk}(D)$, meat(D) & \\
\hline & 4 & $\operatorname{Veg}(\mathrm{D})$, milk(D), meat(D) & \\
\hline & 5 & $\operatorname{Veg}(\mathrm{D}), \operatorname{milk}(\mathrm{D}), \operatorname{meat}(\mathrm{D})$ & \\
\hline & 13 & $\operatorname{Milk}(\mathrm{D})$, meat $(\mathrm{D})$ & \\
\hline
\end{tabular}

Organic chemicals

Chlordane

1
2
4

Fish, veg(I), veg(D)

Noncarcinogen

Fish, veg(I), veg(D)

Fish, water, veg(I), veg(D)

$(\mathrm{UF}=1000)$

PCB-1254

Fish, veg(D), milk(D), meat(D)

Carcinogen (B2)

Fish, veg(D), milk(D), meat(D)

Fish, water, meat(I), milk(I), veg(I)

Fish

Fish

Fish, milk(D), meat(D)

PCB-1260

Fish

Fish, $\operatorname{veg}(D)$, milk(D), meat(D)

Carcinogen (B2)

Fish

Fish

Fish

Vinyl Chloride ${ }^{i j}$

\section{3}

$\operatorname{Veg}(I)$

Carcinogen(A)

Anthracene ${ }^{k}$

Fish, veg(D)

Carcinogen(B2)

4 Fish, water, $\operatorname{veg}(\mathrm{I}), \operatorname{veg}(\mathrm{D})$, milk(D), meat(D)

Benzo(a)anthracene ${ }^{i j}$

Fish, veg(D), milk(D), meat(D)

Carcinogen(B2) 
Table 4.2 (continued)

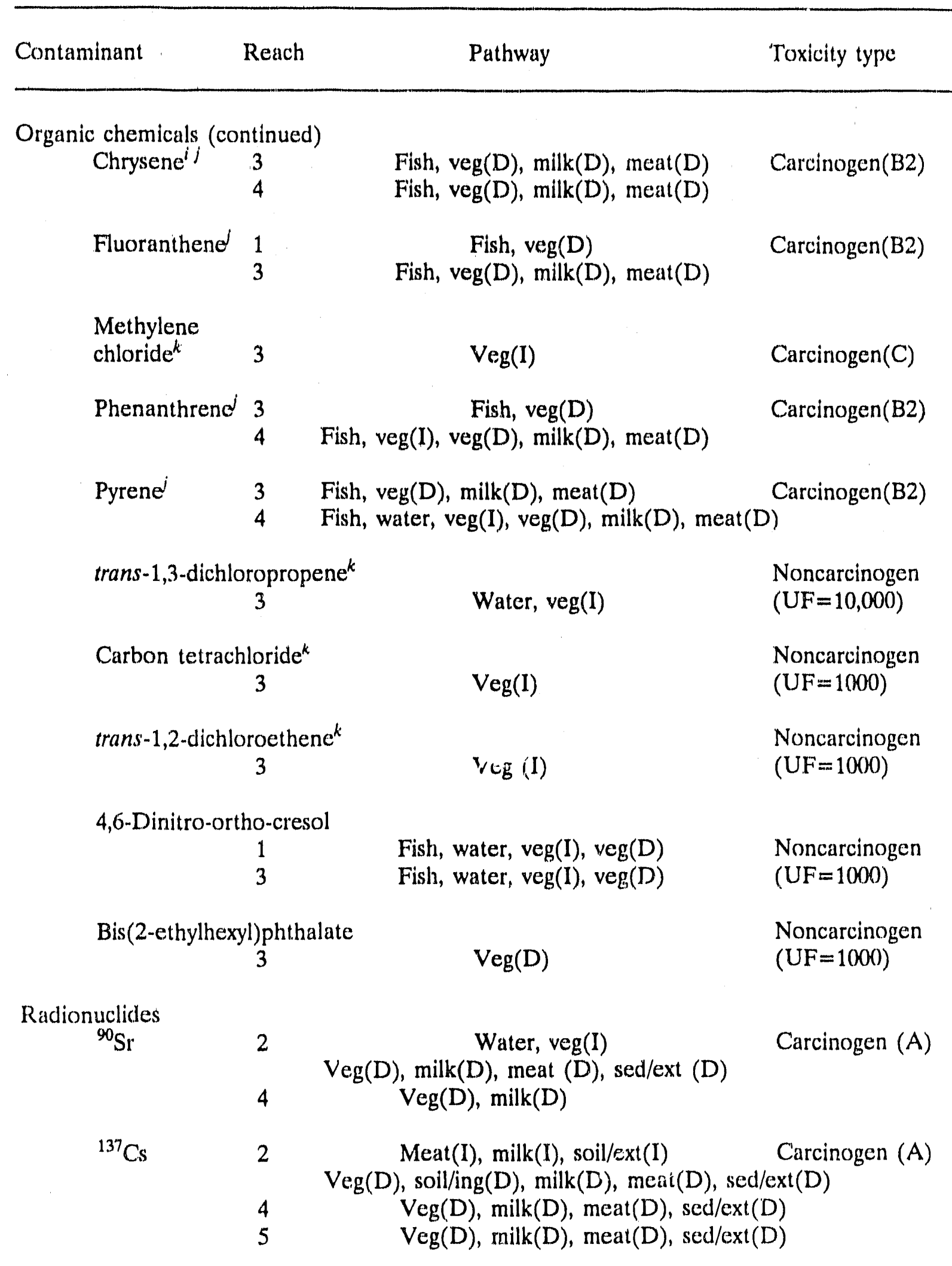


Table 4.2 (continued)

\begin{tabular}{|c|c|c|c|}
\hline Contaminant & Reach & Pathway & Toxicity type \\
\hline \multicolumn{4}{|c|}{ Radionuclides (continued) } \\
\hline${ }^{3} \mathrm{H}$ & 2 & Water & Carcinogen (A) \\
\hline${ }^{610} \mathrm{Co}$ & $\begin{array}{l}2 \\
3 \\
4 \\
5\end{array}$ & $\begin{array}{l}\operatorname{Veg}(D), \operatorname{milk}(D), \operatorname{meat}(D), \operatorname{sed} / \operatorname{ext}(D) \\
\text { Sed/ext(D) } \\
\text { Sed/ext(D) } \\
\text { Sed/ext(D) }\end{array}$ & Carcinogen $(A)$ \\
\hline${ }^{154} \mathrm{Eu}$ & 2 & Sed/ext(D) & Curcirogen $(A)$ \\
\hline${ }^{152} \mathrm{Eu}$ & 2 & Sed/ext(D) & Carcinogen $(\mathrm{A})$ \\
\hline${ }^{241} \mathrm{Am}$ & $\begin{array}{l}2 \\
4\end{array}$ & $\begin{array}{l}\operatorname{Veg}(D) \\
\operatorname{Veg}(D)\end{array}$ & Carcinogen $(\mathrm{A})$ \\
\hline${ }^{239} \mathrm{Pu}$ & 2 & $\operatorname{Veg}(D)$ & Carcinogen (A) \\
\hline${ }^{234} \mathrm{~Pa}$ & 3 & Sed/ext(D) & Carcinogen $(\mathrm{A})$ \\
\hline${ }^{244} \mathrm{Cm}$ & 2 & $\operatorname{Veg}(D)$ & Carcinogen (A) \\
\hline${ }^{238} \mathrm{U}$ & $\begin{array}{l}2 \\
3 \\
4\end{array}$ & $\begin{array}{l}\quad \operatorname{Veg}(D), \text { meat }(D) \\
\operatorname{Veg}(I), \text { meat }(I), \operatorname{veg}(D), \text { meat }(D) \\
\operatorname{Veg}(D), \text { meat }(D), \operatorname{sed} / \operatorname{ext}(D)\end{array}$ & Carcinogen $(A)$ \\
\hline
\end{tabular}

${ }^{a}$ Carcinogen screening index $\geq 10^{-3}$, nuncarcinogen screening index $\geq 1.0$; exposures in all media based on maximum concentrations xeported in fish, sediment, or water.

${ }^{b} \mathrm{I}=$ exposures estimated assuming water irrigation.

${ }^{c} \mathrm{D}=$ exposures estimated assuming sediment dredging.

${ }^{d}$ Under EPA review.

${ }^{e} \mathrm{~A}=$ sufficient human evidence for carcinogenicity,

$\mathrm{B} 1$ = eviderice for carcinogenicity in humans limited,

$\mathrm{B} 2=$ sufficient evidence in animals but none or inadequate data for humans,

$\mathrm{C}=$ limited animal data and inadequate human data.

$f_{U F}=$ uncertainty factor used by EPA to derive a RfD for noncarcinogens.

BAssumed as chromium VI.

"Assumed as uranium salt.

iScrcening indices based on one sample.

islope factor for screening only, based on limited data.

${ }^{k}$ Volatile organic compounds. 
Laboratory.

The chemicals of potentially high priority, found in at least five of the eight reaches sampled, were arsenic, beryllium, chromium, mercury, zinc, selenium, PCB-1254, and PCB-1260. In addition, arsenic, chromium, mercury, nickel, zinc, and PCB-1254 were found at potentially high priority levels in sediment and other media sampled in reference reaches $(10,13$, or 18$)$. These reaches do not receive discharges from DOE/Oak. Ridge Operations.

The highest estimated exposures from the inorganic chemicals were generally the result of assumed dredging of sediment and its possible use as a source of agricultural soil from which crops, milk, and meat were produced. At the present time, this assumed pathway is not a common practice in the reaches of concern, and current environmental regulations may prevent such practices from occurring in the future.

With the exception of the PCBs, most of the potentially high priority orgarilc contaminants in Reaches 3 and 4 are polycyclic aromatic hydrocarbons (PAHs) and commercial pesticides. These chemicals may originate from industrial and agricultural sources other than DOE operations. In addition, the carcinogen slope factor adopted in this study $\left[11.5(\mathrm{mg} / \mathrm{kg} / \mathrm{d})^{-1}\right]$ is used for screening purposes only. Slope factors for PAHs have been removed from current EPA listings because of insufficient data (USEPA 1989d). Some of the organic chemicals listed as potentially high priority may be readily metabolized or are volatile and thus should not accumulate in vegetation, fish, or the food products of grazing animals. Further evaluation of these substances, however, should include additional processes of exposure that have not been included in this screening approach. These processes are exposure to metabolites of parent organic compounds, skin absorption from dermal contact, and inhalation of vapors.

Further analysis of exposures to the potentially high priority substances identified through conservative screening is likely to demonstrate that the risk to human health is of much lower priority because of the large amount of intentional bias applied in conservative screening. In general, substituting average concentrations for maximum concentrations would reduce exposure estimates by about one order of magnitude. Further reductions in the estimate of exposure might be realized with the application of more realistic parameter values derived specifically for the actual conditions of human sposure in the off-site environment (i.e, exposure periods less than 70 years, site-spe ' $i$ estimate of dietary habits).

\subsection{DEFINITELY LOW PRIORITY CONTAMINANTS IDENTIFIED THROUGH CONSERVATIVE SCREENING}

A primary objective of screening is to reduce the number of contaminants included in the CRRFI sampling and analysis effort and in the base-line risk assessment by identifying definitely low priority contaminants. The assumptions used for conservative screening, however, resulted in only 5 inorganic chemicals and 16 radionuclides classified as definitely low priority at one or more reaches over all pathways (Table 4.3). Most of these, however, were classified as definitely low priority substances only under the condition that dredging of sediment would not occur.

Because health risks for carcinogens and noncarcinogens are summed among contaminants in a given reach, within and across exposure pathways, respectively, no reach could be given a definitely low priority, including those reaches assumed to be reference 
Table 4.3. Contaminants assigned a definitely low priority through conservative screening ${ }^{a}$

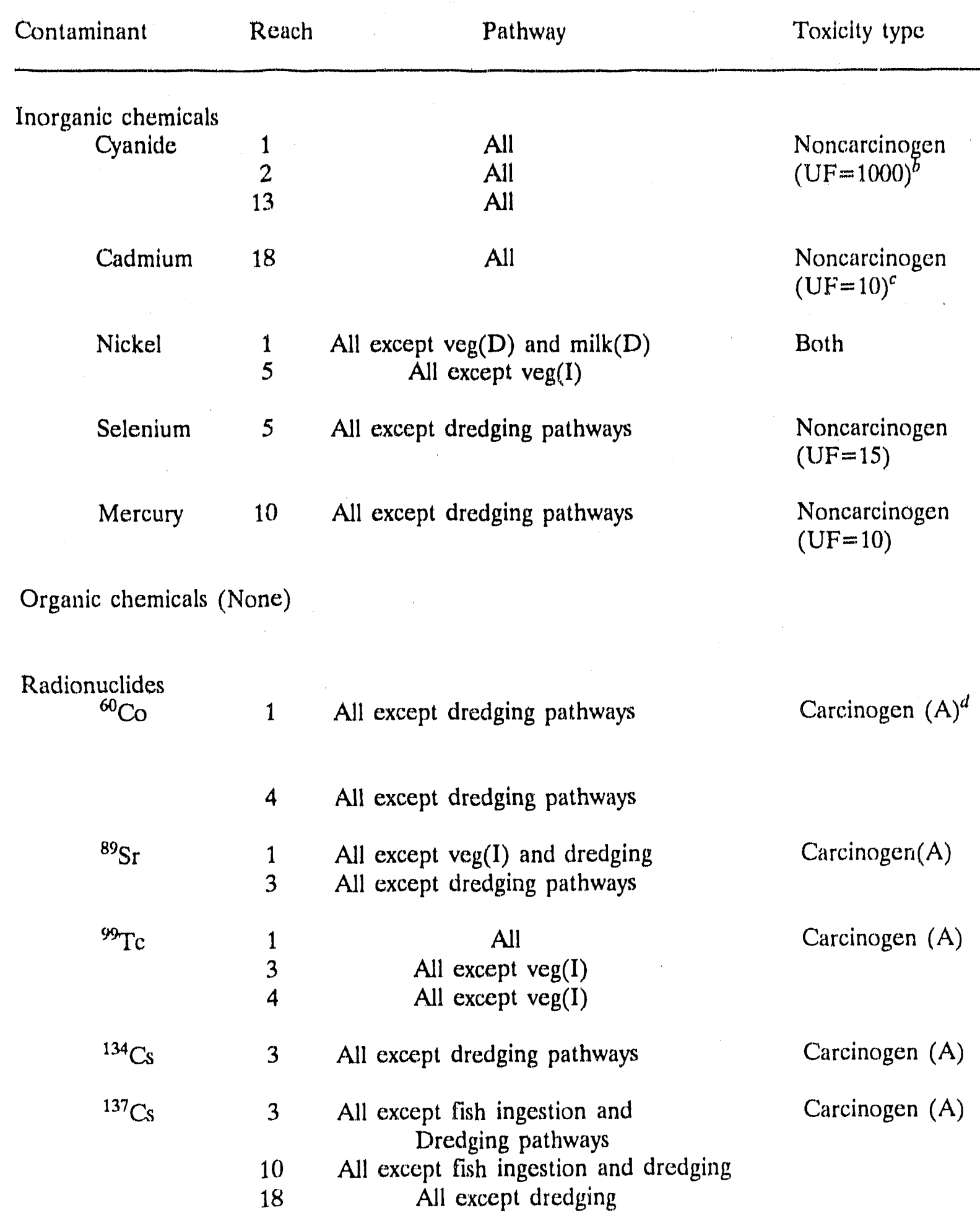


Table 4.3 (continued)

\begin{tabular}{|c|c|c|c|}
\hline Contaminant & Reach & Pathway & Toxicity type \\
\hline \multicolumn{4}{|c|}{ Radionuclides (continued) } \\
\hline${ }^{233} \mathrm{~Pa}$ & 3 & All & Carcinogen (A) \\
\hline \multirow[t]{3}{*}{${ }^{234} \mathrm{~Pa}$} & 1 & All except dredging pathways & \multirow[t]{3}{*}{ Carcinogen $(\mathrm{A})$} \\
\hline & 2 & All except dredging pathways & \\
\hline & 3 & All except dredging pathways & \\
\hline${ }^{232} \mathrm{Th}$ & 1 & All except veg(I) and dredging & Carcinogen $(A)$ \\
\hline \multirow[t]{3}{*}{${ }^{234} \mathrm{Th}$} & 2 & All except dredging pathways & \multirow[t]{3}{*}{ Carcinogen (A) } \\
\hline & 3 & All except dredging pathways & \\
\hline & 4 & All except dredging pathways & \\
\hline \multirow[t]{2}{*}{${ }^{235} U$} & 1 & All except dredging pathways & \multirow[t]{2}{*}{ Carcinogen (A) } \\
\hline & 2 & All except dredging pathways & \\
\hline \multirow[t]{2}{*}{${ }^{236} \mathrm{U}$} & 2 & All & \multirow[t]{2}{*}{ Carcinogen (A) } \\
\hline & 4 & All & \\
\hline \multirow[t]{2}{*}{${ }^{238} \mathrm{U}$} & 1 & All except veg(I) and dredging & \multirow[t]{2}{*}{ Carcinogen $(\mathrm{A})$} \\
\hline & 2 & All except veg(I) and dredging & \\
\hline \multirow[t]{4}{*}{${ }^{238} \mathrm{Pu}$} & 1 & Dredging pathways only & \multirow[t]{4}{*}{ Carcinogen $(A)$} \\
\hline & 3 & All & \\
\hline & 4 & All except dredging pathways & \\
\hline & 5 & All except dredging pathways & \\
\hline \multirow[t]{3}{*}{${ }^{239} \mathrm{Pu}$} & 1 & All except dredging pathways & \multirow[t]{3}{*}{ Carcinogen (A) } \\
\hline & 3 & All except dredging pathways & \\
\hline & 5 & All except dredging pathways & \\
\hline \multirow[t]{2}{*}{${ }^{241} \mathrm{Am}$} & 3 & All except dredging pathways & \multirow[t]{2}{*}{ Carcinogen $(A)$} \\
\hline & 10 & All except dredging pathways & \\
\hline \multirow[t]{2}{*}{${ }^{244} \mathrm{Cm}$} & 3 & All except dredging, pathways & \multirow[t]{2}{*}{ Carcinogen $(\mathrm{A})$} \\
\hline & 10 & All & \\
\hline
\end{tabular}

${ }^{a}$ Carcinogen screening index $<10^{-6}$, noncarcinogen screening index $<0.1$; exposures in all media based on maximum concentrations reported in fish, sediment, or water.

${ }^{b} \mathrm{UF}=$ uncertainty factor used by EPA to derive a RfD for noncarcinogens.

${ }^{c}$ Listed as both a carcinogen and noncarcinogen; however, at a cancer risk level of $10^{-6}$, the noncarcinogen reference dose fartor is more restrictive.

${ }^{d} \mathrm{~A}=$ Sufficient human evidence for carcinogenicity. 
locations (Reach 10, above Norris Reservoir; Reach 13, Poplar Creek above the confluence with East Fork Poplar Creek; and Reach 18, the Tennessee River from Ft. Loudoun Dam to the confluence with the Clinch River). It is likely that the presence of contaminants in these reference reaches are due to industrial and agricultural wastes not related to operations at the DOE Oak Ridge facilities.

\subsection{POTENTIALLY LOW PRIORITY CONTAMINANTS IDENTIFIED THROUGH NONCONSERVATIVE SCREENING}

For carcinogens, no reach was identified as potentially low priority (Fig. 4.1A). All reaches exceeded a nonconservative carcinogen screening index of $10^{-6}$, indicating that potential, maximum exposures at all locations will exceed a $10^{-6}$ lifetime risk of excess cancer. For noncarcinogens, only Reach 10 qualified as a potentially low priority location (Fig. 4.1B). Nonconservative screening identified 36 substances as potentially low priority in one or more pathways at one or more reaches (Table 4.4). Among these, 13 were inorganic chemicals, 6 were organic chemicals, and 17 were radionuclides. However, contaminants designated through nonconservative screening as potentially high priority in one pathway at a given reach are excluded from low priority designation for any other pathway considered at that reach. Twelve of the substances listed through nonconservative screening as potentially low priority in Table 4.4 have also been classified as potentially high priority in Table 4.2 through conservative screening. These twelve substances are listed in Table 4.5. These contradictory results reflect the large differences between the biases of conservative versus nonconservative screening, which include the use of maximum versus average concentrations and the inclusion of additional exposure pathways resulting from possible dredging and irrigation versus casual exposure to water, fish, and sediment only. Careful data acquisition, selection, and review, as well as the justification and application of more realistic assumptions for human health risk assessments are necessary before the priority of the substances listed in Table 4.5 can be evaluated with more certainty.

\subsection{CONTAMINANTS DESIGNATED AS NEITHER HIGH NOR LOW PRIORITY}

Contaminants listed in Appendix B that were not identified in Appendix C or D as definitely or potentially high or low priority remain classified as contaminants of concern. These substances must be scrutinized further. Additional data and site-specific risk evaluations of reasonable maximum exposures (USEPA 1989a) may reclassify these contarninants.

In addition, eight substances detected in the off-site environment could not be classified because values were not available (Appendix A) for either oral or inhalation RfDs or for cancer slope factors (Table 4.6). The potential toxicity of these substances will have to be evaluated further before recommendations can be made about the potential importance of these substances.

The majority of the organic chemicals were not classified because they were below limits of detection (Appendix B). For example, only 19 organic compounds were quantified above the limits of detection in any sample at any reach. However, for more than 40 organic substances, the detection limits are equivalent to concentrations that would lead to 
Table 4.4. Contaminants assigned a potentially low priority through nonconservative screening ${ }^{a}$

\begin{tabular}{|c|c|c|c|}
\hline Contaminant & Reach & Pathway & Toxicity type \\
\hline $\begin{array}{c}\text { Inorganic chemicals } \\
\text { Chromium }\end{array}$ & $\begin{array}{c}1 \\
2 \\
3 \\
4 \\
5 \\
10\end{array}$ & $\begin{array}{l}\text { All } \\
\text { Sediment and fish ingestion } \\
\text { All } \\
\text { Sediment and fish ingestion } \\
\text { Sediment and fish ingestion } \\
\text { Sediment ingestion }\end{array}$ & $\begin{array}{l}\text { Noncarcinogen } \\
(\mathrm{UF}=500)^{b}\end{array}$ \\
\hline Silver & $\begin{array}{l}1 \\
2 \\
3 \\
4\end{array}$ & $\begin{array}{c}\text { Fish ingestion } \\
\text { All } \\
\text { Sediment and fish ingestion } \\
\text { Sediment ingestion }\end{array}$ & $\begin{array}{l}\text { Noncarcinogen } \\
(\mathrm{UF}=2)\end{array}$ \\
\hline Zinc & $\begin{array}{r}1 \\
2 \\
3 \\
4 \\
5 \\
13\end{array}$ & 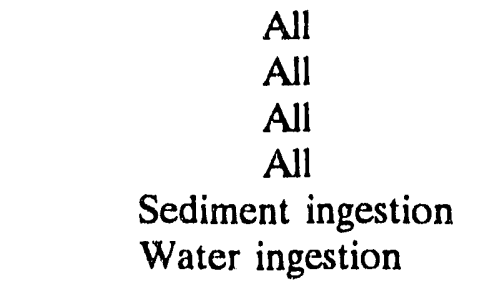 & $\begin{array}{l}\text { Noncarcinogen } \\
(\mathrm{UF}=10)\end{array}$ \\
\hline Nickel & $\begin{array}{c}1 \\
2 \\
3 \\
4 \\
5 \\
10 \\
13\end{array}$ & $\begin{array}{l}\quad \text { All } \\
\text { Sediment ingestion } \\
\quad \text { All } \\
\text { All } \\
\text { Sediment ingestion } \\
\text { Sediment ingestion } \\
\text { Water ingestion }\end{array}$ & $\begin{array}{l}\text { Noncarcinogen } \\
(\mathrm{UF}=300)\end{array}$ \\
\hline Cadmium & $\begin{array}{l}1 \\
2 \\
3 \\
4 \\
5\end{array}$ & $\begin{array}{l}\text { Sediment and fish } \\
\text { All } \\
\text { All } \\
\text { All } \\
\text { Fish ingestion }\end{array}$ & $\begin{array}{l}\text { Noncarcinogen } \\
(\mathrm{UF}=10)\end{array}$ \\
\hline Cyanide & $\begin{array}{l}1 \\
2 \\
3 \\
4\end{array}$ & $\begin{array}{l}\text { Sediment ingestion } \\
\text { Water ingestion } \\
\text { Water ingestion } \\
\text { Water ingestion }\end{array}$ & $\begin{array}{l}\text { Noncarcinogen } \\
(\mathrm{UF}=1000)\end{array}$ \\
\hline
\end{tabular}


Table 4.4 (continued)

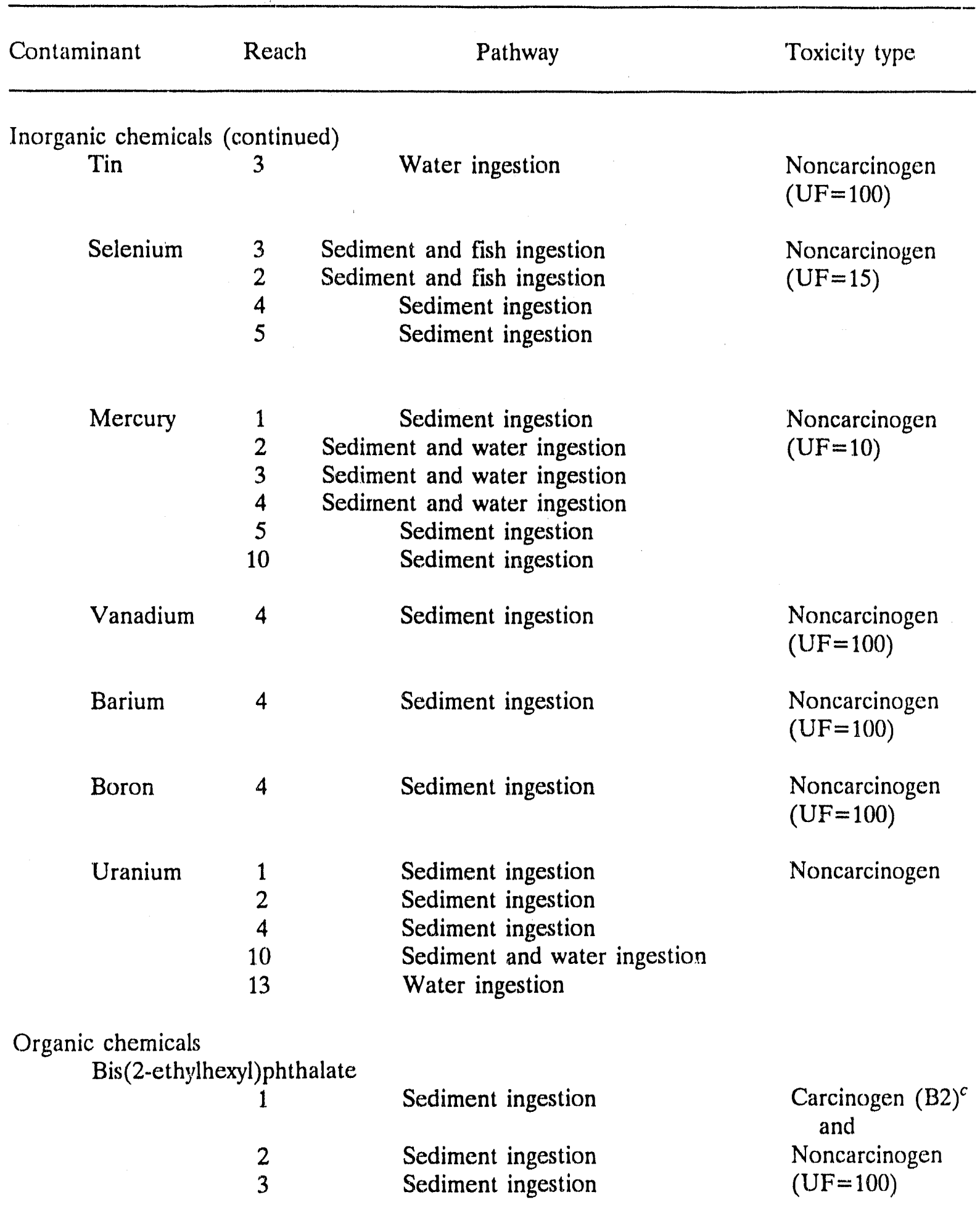


Table 4.4 (continued)

\begin{tabular}{|c|c|c|c|}
\hline Contaminant & Reach & Pathway & Toxicity type \\
\hline \multicolumn{4}{|c|}{ Organic chemicals (continued) } \\
\hline Methy & oride & & $\begin{array}{l}\text { Carcinogen (B2) } \\
\text { and }\end{array}$ \\
\hline & 1 & Sediment ingestion & $\begin{array}{l}\text { noncarcinogen } \\
(\mathrm{UF}=100)\end{array}$ \\
\hline Trichlc & methane & Water ingestion & Noncarcinogen \\
\hline Tetrac & $\begin{array}{c}\text { iylene } \\
3\end{array}$ & Water ingestion & $\begin{array}{l}\text { Noncarcinogen } \\
(\mathrm{UF}=100)\end{array}$ \\
\hline $1,1,1-1$ & $\begin{array}{l}\text { ethane } \\
3\end{array}$ & Water ingestion & $\begin{array}{l}\text { Noncarcinogen } \\
(\mathrm{UF}=100)\end{array}$ \\
\hline Di-n- $-b$ & $\begin{array}{l}\text { halate } \\
3\end{array}$ & Sediment ingestion & $\begin{array}{l}\text { Noncarcinogen } \\
(\mathrm{UF}=100)\end{array}$ \\
\hline $\begin{array}{l}\text { Radionuclides } \\
{ }^{60} \mathrm{Co}\end{array}$ & $\begin{array}{l}1 \\
3 \\
4 \\
5\end{array}$ & $\begin{array}{l}\text { Sediment and fish ingestion } \\
\text { Sediment ingestion } \\
\text { Sediment and fish ingestion } \\
\text { Sediment ingestion }\end{array}$ & Carcinogen $(\mathrm{A})$ \\
\hline${ }^{89} \mathrm{Sr}$ & $\begin{array}{r}1 \\
2 \\
4 \\
10\end{array}$ & $\begin{array}{l}\text { Sediment ingestion } \\
\text { Sediment ingestion } \\
\text { Sediment and fish ingestion } \\
\text { Sediment ingestion }\end{array}$ & Carcinogen(A) \\
\hline${ }^{90} \mathrm{Sr}$ & $\begin{array}{c}1 \\
2 \\
3 \\
4 \\
5 \\
10\end{array}$ & $\begin{array}{l}\text { Sediment ingestion } \\
\text { Sediment ingestion } \\
\text { Sediment ingestion } \\
\text { Sediment ingestion } \\
\text { Sediment ingestion } \\
\text { Sediment ingestion }\end{array}$ & Carcinogen $(\mathrm{A})$ \\
\hline${ }^{99} \mathrm{Tc}$ & $\begin{array}{l}1 \\
3 \\
4\end{array}$ & $\begin{array}{l}\text { Fish ingestion } \\
\text { Fish ingestion } \\
\text { Fish ingestion }\end{array}$ & Carcinogen (A) \\
\hline
\end{tabular}


Table 4.4 (continued)

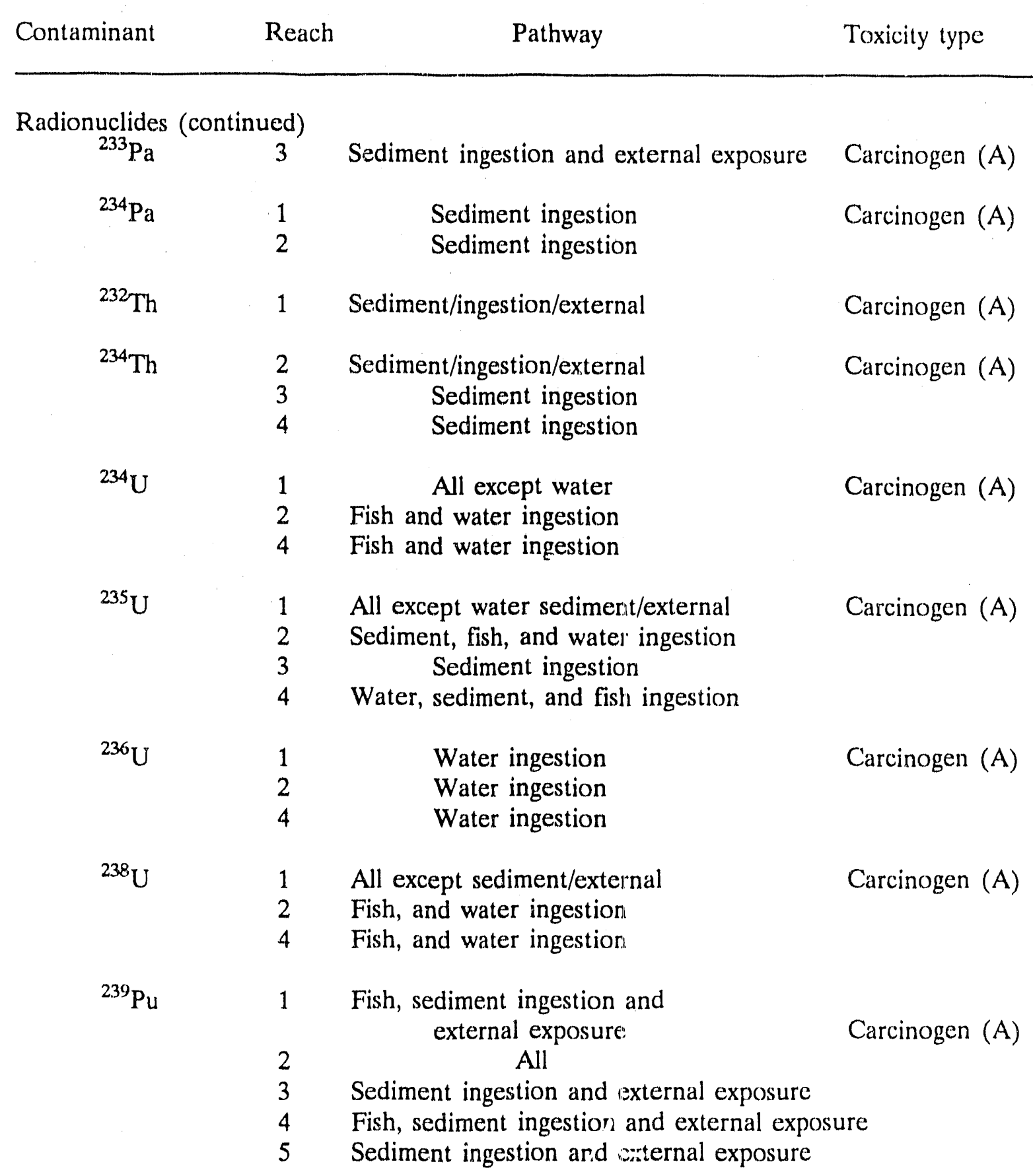


Table 4.4 (continued)

\begin{tabular}{|c|c|c|c|}
\hline Contaminant & Reach & Pathway & Toxicity type \\
\hline \multicolumn{4}{|c|}{ Radionuclides (continued) } \\
\hline${ }^{241} \mathrm{Am}$ & 3 & $\begin{array}{l}\text { Sediment ingestion and } \\
\text { external exposure }\end{array}$ & Carcinogen (A) \\
\hline$y$ & 10 & Sediment ingestion and external exposure & \\
\hline${ }^{244} \mathrm{Cm}$ & $\begin{array}{r}3 \\
4 \\
4 \\
10\end{array}$ & $\begin{array}{l}\text { Sediment ingestion and } \\
\text { external exposure } \\
\text { Sediment ingestion and external exposure } \\
\text { Sediment ingestion and external exposure }\end{array}$ & Carcinogen $(\mathrm{A})$ \\
\hline
\end{tabular}

${ }^{a}$ Carcinogen screening index $<10^{-7}$, noncarcinogen screening index $<0.01$; exposures based on average concentrations reported in fish, sediment, and water.

${ }^{b} \mathrm{UF}=$ uncertainty factor used by EPA to derive a RHD for noncarcinogens.

${ }^{c} \mathrm{~A}=$ Sufficient human evidence for carcinogenicity,

B2 = Sufficient evidence in animals but none or inadequate data for humans. 
Table 4.5. Contaminants within a given reach assigned both a potentially low priority through nonconservative screening and a potentially high priority using conservative screening

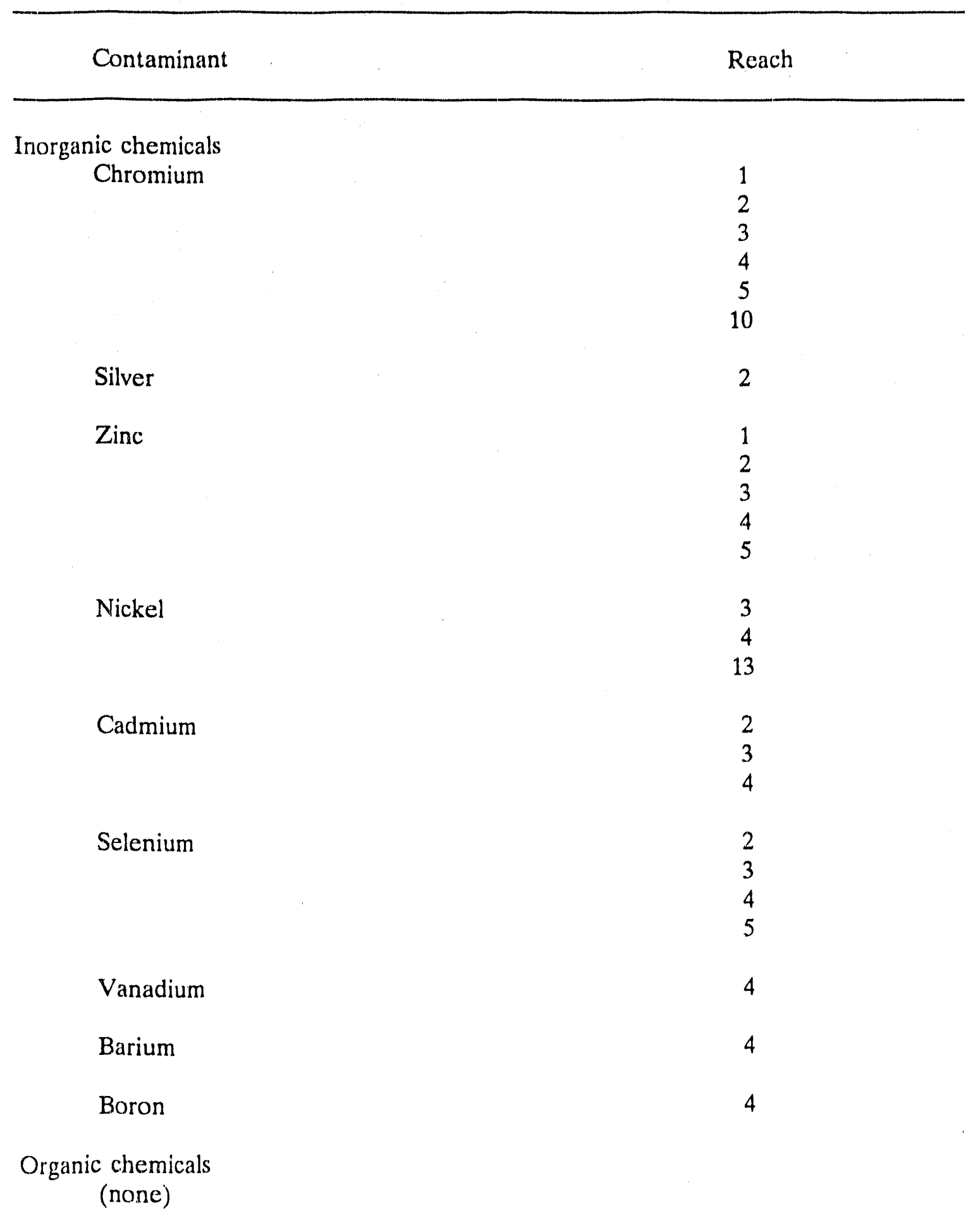


Table 4.5 (continued)

\begin{tabular}{cc}
\hline Contaminant & Reach \\
\hline Radionuclides & 2 \\
Pu-239 & 2 \\
Sr-90 & 3 \\
Co-60 & 4 \\
& 5 \\
\hline
\end{tabular}


Table 4.6. Potential contaminants detected in either sediment, water, or fish within a given reach for which no values were obtained for either reference dose factors or cancer slope factors

\begin{tabular}{|c|c|}
\hline Contaminant & Reach \\
\hline \multicolumn{2}{|l|}{ Inorganic Chemicals } \\
\hline \multirow[t]{3}{*}{ Aluminum } & 2 \\
\hline & 3 \\
\hline & 4 \\
\hline \multirow[t]{6}{*}{ Copper } & 1 \\
\hline & 2 \\
\hline & 3 \\
\hline & 4 \\
\hline & 5 \\
\hline & 13 \\
\hline \multirow[t]{7}{*}{ Lead } & 1 \\
\hline & 2 \\
\hline & 3 \\
\hline & 4 \\
\hline & 5 \\
\hline & 10 \\
\hline & 13 \\
\hline Molybdenum & 3 \\
\hline Niobium & 3 \\
\hline \multirow[t]{2}{*}{ Titanium } & 3 \\
\hline & 4 \\
\hline \multirow[t]{5}{*}{ Zirconium } & 1 \\
\hline & 2 \\
\hline & 3 \\
\hline & 4 \\
\hline & 10 \\
\hline Organic Chemicals & \\
\hline 4-Nitrophenol & 3 \\
\hline Radionuclides (none) & \\
\hline
\end{tabular}


calculated lifetime risks of cancer $\geq 10^{6}$ when concentrations in sediment, lish, and water were set equal to the lowest reported limit of detection among all reaches (Appendix $E$ ). Of these, 30 exceeded a carcinogen screening index of $10^{\prime 5}$ and 20 exceeded $10^{\prime 4}$. The detection limit for benzidine in flsh exceeded a carcinogen screening index of $10^{2}$, assuming a lish consumption rate for nonconservative screening? ${ }^{3}$. In many cases, it will be necessary to either document that these substances are not associated with roleases from DOE/Oak Ridge operations or to develop improved analytical procedures to confirm that a given contaminant is not present at concentrations considered to be of concern.

\subsection{COMPARISON OF SCREENING RESULTS USING HEALTH RISK AND ECOLOGICAL. END POINTS}

Screening results obtained with health risk end points are compared with ecological risk end points in Appendix F. Seven inorganic contaminants (aluminum, calcium, copper, cyanide, lead, lithium, and manganese) were identified as high-priority contaminants using ecological risk end points that were not identified as potentially high priority contaminants using health risk end points. Of these seven, only cyanide was identified as a definitely low priority contaminant by conservative screening with health risk end points (Table 4.3).

Calcium and manganese are essential elements for human health and were not included in the screening analysis using health risk end points. Aluminum, lead, and copper are known to be toxic to human health but were not listed as potentially high priority because current slope factors or RIDs were not available from EPA (IRIS 1989). However, these chemicals were identified as contaminants of concern that will require additional analyses as information becomes available. Lithium was left out of the data base that was analyzed using health risk end points, but was included in the screening analysis using ecological risk end points. Therefore, lithium will be considered a contaminant of concern and will be investigated further.

Screening analyses using health risk end points identified 3 inorganics (antimony, barium, and beryllium), 13 organic contaminants, and 11 radionuclides as potentially high priority pollutants that were not identified by screening with ecological end points (Table F1). Radionuclides were not considered in the screening analysis using ecological end points (Suter 1990) because previous studies in White Oak Lake where concentrations of radionuclides are greater than those found in the off-site environments, indicated that deletarious effects could not be detected on populations of aquatic organisms that inhabit the lake. Therefore, it was assumed that lower concentrations of radionuclides in the off-site environment should not affect populations of aquatic biota (Blaylock and Trabalka 1978).

A majority of the 13 organic contaminants that were not identified by ecological risk end points are carcinogens. Ecological screening is more concerned with effects at the population level than at the individual level; therefore, carcinogens do not receive as much consideration in ecological risk analyses as they do for human health protection.

3 This result was due to the use of an inappropriate analytical method gas chromatograph/mass spectrometry for benzidine leading to a high detection limit. 


\section{DISCUSSION}

To the best of our knowledge, this study is the first of its kind 10 employ both conservative and nonconservative screcning procedures. This approach has proved most useful for identifying high-priority contaminants. Nonconservative screening has tentatively identified definitely high priority contaminants in two reaches (arsenic and thallium in Reach 1 and ${ }^{137} \mathrm{Cs}$ in Reach 2) and eight other potentially high priority substances within five reaches of the off-site environment (Table 4.1). These are the contaminants that should receive the most scrutiny for lurther investigation and remediation considerations. Such scrutiny should include a thorough evaluation of all potential exposure pathways, the specific patterns of utilization exhibited by potentially exposed population groups, and the evidence used to derive cancer slope factors and/or noncarcinogen RIDs.

Although the end points of this document are quantitative estimates of health risk, care must be taken when interpreting these results for purposes other than those of screening. We cannot exclude the possibility, because of the conservatism adopted by EPA in deriving RfDs and cancer slope factors, that the true risk may be zero for many of the contaminants identified of concern. More detailed discussions of the strength and weaknesses of the use of RfDs for noncarcinogens and slope factors for carcinogens can be found in Jones and Owen (1989) and USEPA (1989a).

The intentional bias within conservative screening, using maximum concentrations, parameter values, and model assumptions that are designed to reduce the chance of underestimating potential exposure, and the adoption of a lower screening criterion of $10^{-6}$ for carcinogens and 0.1 for noncarcinogens resulted in very few substances classified as definitely low priority contaminants. Nevertheless, nonconservative screening, which used average concentrations, has shown that all reaches are likely to exhibit potential maximum exposures to carcinogens that exceed a $10^{-6}$ lifetime risk of excess cancer incidence (assuming that the use of EPA carcinogen slope factors is not, in and of itself, an overly conservative practice).

It should be obvious that the number of contaminants designated as low priority will be influenced by the screening criteria selected. Any justification for screening critcria less restrictive than those used in this study should decrease the number of contaminants of concern. Modification of the screening criteria used in this study should be based on guidance from regulatory authorities as to the levels of risk below which remedial action should not be required.

Some of the polentially high priority contaminants identified in this report may be artifacts due to the occurrence of false positives in sample analysis combined with the effect of compound conservatism in the use of models. Some substances designated as potentially high priority had only one measured value in the entire data base. In the case of thallium, which was designated as definitely high priority in fish of Reach 1, the average fish concentration was based on only four samples, that were above the limit of detection. Two of these samples were equal to the limit of detection $(1.0 \mathrm{mg} / \mathrm{kg}$ ) while 22 additional samples were less than the limit of detection. Possible artifacts have been identified in the summary tables in Section 4 of this report; however, additional data will be necessary to confirm the true presence or absence of these substances. 
The base-line risk assessment, which will follow this screening exercise, should include the development of site-specific pathway models and improved assumptions about pathway utillzation by humans to reduce the amount of conservatism in the exposure cstimate without increasing the chance of underestimating actual exposures to individuals residing in the off-site environment. An important area for further investigation is a thorough examination of the possibilities for sediment dredging and, if nocessary, restricting the utilization of sediment dredged from the off-site environinent.

In general, many of the contaminants identified as potentially important for human health risk considerations were also identified by Suter (1990) using environmental/ecological end points. The primary exceptions were: essential elements (calcium and munganese), which are not of concern for health risk but may affect aquatic biota; the radionuclides, which are known human carcinogens, but, at the levels present in the off-site environment, should not have a measurable ecological impact; and cyanide, which was classified as definitely low priority for human health risk, but given a potentially higher priority for environmental/ecological risk. The majority of organic substances considered potentially important for human health risk but not listed for ecological risk are chemicals classified as human carcinogens.

Investigations extending beyond this study should include an analysis of compliance with environmental regulations. The screening analysis performed in this report does not address the issues involved with regulatory compliance. Large discrepancies, however, are known to exist in risk levels associated with current environmental regulations for specific contaminants (Jones and Owen 1989). The prevalence of these discrepancies is likely to result in modifications to current environmental regulations in order for the acceptability of mixtures of contaminants in environmental media to be regulated on a consistent basis.

The results presented in this report have been produced after several iterations of calculations. These iterations have occurred because of inconsistencies in results produced by the first series of calculations. Investigation of these inconsistencies led to the identification of errors in the data base. As a consequence of this screening exercise, the quality of the present data base for contaminants measured in the off-site environment has been improved substantially. 


\section{CONCL.USIONS}

This report demonstrates the utility of using both conservatively biased and nonconservative approaches for screening of large data sets. Screening of these data is necessary to determine sampling priorities and to focus the efforts of the base-line risk analysis. The data base used for screening included approximately 9,000 values for contaminants in sediment, 9,000 for fish, and 25,000 for water. Many of these were organic chemicals that were below the limits of detection. Of those contaminants that were detected, conservative screening was not successful in identifying many as having a definitely low priority for further analysis.

Nonconservative screening tentatively identified three contaminants, arsenic in the water of McCoy Branch at Reach 1, thallium in fish at Reach 1, and ${ }^{137} \mathrm{Cs}$ in the sediment of the embayment of White Oak Creek downstream from White Oak Lake, as definitely high priority substances requiring further analysis and possible consideration for remediation. The locations where these samples were taken are within the boundaries of the DOE/ORR. In addition, the presence of thallium may be an analytical artifact. Nonconservative screening also identified arsenic, thallium, uranium, PCB 1254 and 1260 , chlordane, ${ }^{\infty} \mathrm{Co}$ and ${ }^{234} \mathrm{~Pa}$ as potentially high priority contaminants in at least one or more locations (primarily Reaches 1 through 5). The presence of arsenic, thallium, and chlordane may be the consequence of industrial and agricultural operations other than DOE/Oak Ridge Operations. No reach was identified as low priority, or even potentially low priority, given a screening criterion of $10^{-6}$ for carcinogens.

This screening analysis has used criteria that are entirely risk-based. Screening indices for carcinogens have been calculated using EPA-approved or -proposed slope factors for inorganic and organic chemicals and a revised dose-to-risk conversion factor for radionuclides. Noncarcinogen screening indices have been based on the use of EPAapproved or -proposed RfDs. Despite the application of these screening indices, this report should not be construed as a human health risk assessment.

The conservative approach used for this screening analysis is more restrictive and the nonconservative approach is less restrictive than the approach that is typically taken to estimate reasonable maximum exposures to potential human receptors (USEPA 1989a). The intent of this study was to perform an initial scoping exercise, based on existing data, to identify contaminants of possible concern prior to undertaking a detailed sampling and analysis effort to acquire additional data for a base-line assessment of human health risk. In addition, because of large uncertainty in the application of slope factors and RfDs at low concentrations, one cannot exclude the possibility that the true risk to individuals in the off-site environment is actually zero.

Further data and more refined analysis of current data using more realistic, site-specilic assumptions should result in a different classification of many of the contaminants of concern identified in this report; however, it is unlikely that potential maximum exposures cstimated from nonconservative screening have been grossly overstated unless humans are actively prevented from utilizing the media in which contaminants have been sampled. 


\section{REFERENCES}

Ashwood, T. L., Olsen, C. R., Larsen, I. L., and Lowry, P. D. 1986. Sediment Contamination in Streams Surrounding the Oak Ridge Gaseous Diffusion Plant. ORNL/TM-9791. Martin Marietta Energy Systems, Inc., Oak Ridge Natl. Lab.

Baes, C. F. III., Sharp, R. D., Sjoreen, A. L., and Shor, R. W. 1984. A Review and Analysis of Parameters for Assessing Transport of Environmentally Released Radionuclides Through Agriculture. ORNL/TM-5786. Martin Marietta Energy Systems, Inc., Oak Ridge Natl. Lab.

Baes, C. F. III., Killough, G. G., Moore, R. E., and Till, J. E. 1989. Computer Models to Equate Soil Contaminants with Health Impacts: DECOM, Radwex, and Dechem. ORNL/TM-11325. Environmental Sciences Division Publication 3368. Martin Marietta Energy Systems, Inc., Oak Ridge Natl. Lab.

Blaylock, B. G. and Trabalka, J. R. 1978. Evaluating the effects of ionizing radiation on aquatic biota. IN: Lett, J. T. and Adler, H. (eds.) Advances of Radiation Biology. Academic Press, New York.

Clarke, R. H. 1988. NRPB-1, Statement of Evidence to the Hinkley Point C Inquiry. NRPB-M160. National Radiological Protection Board, Chilton, U.K.

Fritzsche, A. E. 1987. An Aerial Radiological Survey of the White Oak Creek Floodplain Oak Ridge Reservation, Oak Ridge, Tennessee. EGG-10281-1136. EG\&G, Oak Ridge, Tenn.

Hoffman, F. O., Blaylock, B. G., Travis, C. C., Daniels, K. L., Etnier, E. L., Cowser, K. E., Weber, C. W. 1984. Preliminary Screening of Contaminants in Sediments. ORNL/TM-9370. Environmental Sciences Division Publication 2400. Martin Marietta Energy Systems, Inc., Oak Ridge Natl. Lab.

International Atomic Energy Agency (IAEA). 1982. Generic Models and Parameters for Assessing the Environmental Transfer of Radionuclides from Routine Releases. Safety Series No. 57. Int. Atomic Energy Agency, Vienna.

IRIS 1989. Integrated Risk Information System (data base), U.S. Environmental Protection Agency, Office of Research and Development, Washington, D.C., December.

Jones, C. G., McNeese, L. E., Baker, C. L., Bates, L. D., Snodgrass, C. W., and Stratton, L. E. $1990 . \quad$ Environmental Restoration and Waste Management SiteSpecific Plan for the Oak Ridge Reservation. K/ESH-1. Martin Marietta Energy Systems, Inc., Oak Ridge, Tennessee. 
Jones, T. D. and Owen, B. A. 1989. Health Risks from Mixtures of Radionuclides and Chemicals in Drinking Water. ORNL-6533. Martin Marietta Energy Systems, Inc., Oak Ridge Natl. Lab.

Lappenbush, W. L. 1988. Contaminated Waste Sites, Property and Your Health. Lappenbush Environmental Health, Inc. Alexandria, Va.

Loar, J. M., Burkhart, F. A., Cada, G. F., Huckabee, J. W., Kitchings, J. T., Kumar, K. D., Sasson, A. M., Solomon, J. A., and Story, J. D. 1981. Ecological Studies of the Biotic Communities in the Vicinity of the Oak Ridge Gaseous Diffusion Plant. ORNL/TM-6714. Martin Marietta Energy Systems, Inc., Oak Ridge Natl. Lab.

Loar, J. M. (ed.). Adams, S. M., Blaylock, B. G., Boston, H. L., Huston, M. A., Kimmel, B. L., Kitchings, J. T., Olsen, C. R., Ryon, M. G., Smith, J. G., Southworth, G. R., Stewart, A. J., Walton, B. T., Amano, H., Garten, C. T., and Meyers, L. J. 1987. First Annual Report on the ORNL Biological Monitoring and Abatement Program. ORNL/TM-10399. Martin Marietta Energy Systems, Inc., Oak Ridge Natl. Lab.

Loar, J. M. (ed). 1988. Second Annual Report on the ORNL Biological Monitoring and Abatement Program. ORNL/TM. Martin Marietta Energy Systems, Inc., Oak Ridge Natl. Lab.

Lyman, W. J., Reehl, W. F., and Rosenblatt, D. H. (eds.). 1982. Handbook of Chemical Property Estimation Methods: Environmental Behavior of Organic Compounds. Mcgraw Hill, New York.

National Council on Radiation Protection and Measurements (NCRP). 1984. Radiological Assessment: Predicting the Transport, Bioaccumulation, and Intake by Man of Radionuclides Released to the Environment. NCRP Report 76, Bethesda, Maryland.

National Council on Radiation Protection and Measurements (NCRP). 1989. Screening Techniques for Determining Compliance with Environmental Standards, Releases of Radionuclides to the Atmosphere. NCRP Commentary 3. Bethesda, Maryland.

Oakes, T. W., Ohnesorge, W. F., Eldridge, J. S., Scott, T. G., Parsons, D. W., Hubbard, H. M., Sealand, O. M., Shanks, K. E., and Eyman, L. D. 1982. Technical Background Information for the Environmental Safety Report, Volume 5: The 1977 Clinch River Sediment Survey--Data Presentation. ORNL-5878. Martin Marietta Energy Systems, Inc., Oak Ridge Natl. Lab.

Olsen, C. R., Larsen, I. L., Lowry, P. D., Moriones, C. R., Ford, C. J., Dearstone, K. C., Turner, R. R., and Kimmel, B. L. 1990. Transport and Accumulation of Cesium-137 and Mercury in the Clinch River and Watts Bar Reservoir System. ORNL/ER-7. Martin Marietta Energy Systems, Inc., Oak Ridge Natl. Lab. 
Rogers, R. G., Daniels, K. L., Goodpasture, S. T., Kimbrough, C. W., and Whitfield, E. W. 1988a. Environmental Surveillance of the U.S. Department of Energy Oak Ridge Reservation and Surrounding Environs During 1987. Volume 1: Narrative, Summary, and Conclusions. ES/ESH-4/V 1. Martin Marietta Energy Systems, Inc., Oak Ridge Natl. Lab.

Rogers, R. G., Daniels, K. L., Goodpasture, S. T., Kimbrough, C. W., and Whitfield, E. W. 1988b. Environmental Surveillance of the U.S. Department of Energy Oak Ridge Reservation and Surrounding Environs During 1987. Volume 2: Data Presentation. ES/ESH-4/V 2. Martin Marietta Energy Systems, Inc., Oak Ridge Natl. Lab.

Rogers, R. G., Daniels, K. L., Goodpasture, S. 'T., Kimbrough, C. W., and Prince, N. L. 1989a. Environmental Surveillance of the U.S. Department of Energy Oak Ridge Reservation and Surrounding Environs During 1988. Volume 1: Narrative, Summary, and Conclusions. ES/ESH-8/V1. Martin Marietta Energy Systems, Inc., Oak Ridge Natl. Lab.

Rogers, R. G., Daniels, K. L., Goodpasture, S. T., Kimbrough, C. W., and Prince, N. L. 1989b. Environmental Surveillance of the U.S. Department of Energy Oak Ridge Reservation and Surrounding Environs During 1987. Volume 2: Data Presentation. ES/ESH-8/V2. Martin Marietta Energy Systems, Inc., Oak Ridge Natl. Lab.

Rupp, E. M. 1980. "Age dependent values of dietary intake for assessing human exposure to environmental pollutants." Health Physics 9:151-163.

Rupp, E. M., Miller, F. M., Baes III, C. F. 1980. "Some results of a recent survey of fish and shellfish consumption by age and region of U.S. residents." Health Physics 9:165-175.

Stather, J. W., Muirhead, C. R., Edwards, A. A., Harrison, J. D., Lloyd, D. C., and Wood, N. R. 1988. Health Effects Models Developed from the 1988 UNSCEAR Report. NRPB-R226. National Radiological Protection Board, Chilton, U. K.

STORET User's Handbook. 1985. Computer Sciences Corporation, 6521 Arlington Boulevard, Falls Church, VA.

Suter, G. 1990. (in Press). Screening-Level Risk Assessment for Off-Site Ecological Effects in Surface Waters Downstream from the U.S. Department of Energy Oak Ridge Reservation. ORNL/ER-8. Martin Marietta Energy Systems, Inc., Oak Ridge Natl. Lab.

Tennessee Valley Authority (TVA). 1985a. Instream Contaminant Study, Task 2 Sediment Characterization, Vol. I. Report to U.S. Department of Energy, Oak Ridge Operations Office. Tennessee Valley Authority, Office of Natural Resources and Economic Development, Knoxville, Tenn. 
Tennessee Valley Authority (TVA). 1985b. Instream Contaminant Study, Task 4 Fish Sampling and Analysis. Report to U.S. Department of Energy, Oak Ridge Operations Office. Tennessee Valley Authority, Office of Natural Resources and Economic Development, Knoxvile, Tenn.

Travis, C. C., Blaylock, B. G., Daniels, K. L., Gist, C. S., Hoffman, F. O., McElhaney, R. J., and Weber, C. W. 1989. Final Report of the Oak Ridge Task Force Concerning Public Health Impacts of the Off-Site Contamination in East Fork Poplar Creek and Other Area Streams. ORNL/TM-11252. Martin Marietta Energy Systems, Oak Ridge Natl. Lab.

United Nations Scientific Committee on the Effects of Atomic Radiation (UNSCEAR) 1988. Sources, Effects, and Risks of Ionizing Radiation. 1988 Report to the General Assembly, with Annexes. U.S. Environmental Protection Agency. United Nations, New York.

USEPA (U.S. Environmental Protection Agency). 1979. Water-Related Environmental Fate of 129 Priority Pollutants. Vol. 1, Introduction and Technical Background, Metals, and Inorganics, Pesticides and PCBs. EPA-440/4-79-029a. U.S. Office of Water Planning and Standards, EPA Office of Water and Waste Management, Washington, D.C.

USEPA (U.S. Environmental Protection Agency). 1989a. Interim Final: Risk Assessment Guidance for Superfund. Vol. I: Human Health Evaluation Manual. OSWER Directive 9285.7-01a. EPA Office of Emergency and Remedial Response, Washington, D.C.

USEPA (U.S. Environmental Protection Agency). 1986. Quality Criteria for Water. EPA 440/5-86-001. May 1, 1987 update. EPA Office of Water Regulations and Standards, Washington, D.C.

USEPA (U.S. Environmental Protection Agency). 1989b. Exposure Factors Handbook, EPA Office of Health and Environmental Assessment, Research and Development. EPA 600/8/89/043. Washington, D.C.

USEPA (U.S. Environmental Protection Agency). 1989c. Health Effects Assessment Summary Tables, Fourth Quarter, FY 1989. OERR 9200.6-303-(89-4). EPA Office of Water Regulations and Standards, Washington, D.C.

USEPA (U.S. Environmental Protection Agency). 1989d. Health Effects Assessment Summary Tables and User's Guide, Fourth Quarter, FY 1989. EPA Office of Emergency and Remedial Response, Washington, D.C.

Yang, Y. and Nelson, C. B. 1984. An Estimation of the Daily Average Food Intake by Age and Sex for Use in Assessing the Radionuclide Intake of Individuals in the General Population. EPA 520/1-84-021. U.S. Environmental Protection Agency, Office of Radiation Programs, Washington, D.C. 
Appendix A

REFERENCE DOSE FACTORS AND SLOPE (CANCER POTENCY) FACTORS FOR ORGANIC AND INORGANIC CHEMICAIS AND RADIONUCLIDES 
Table A1. Reference dose factors and slope (cancer potency) factors for inorganic compounds $a$

\begin{tabular}{|c|c|c|c|c|}
\hline $\begin{array}{l}\text { Inorganic } \\
\text { compound }\end{array}$ & $\begin{array}{c}\text { Oral } \\
\text { reference } \\
\text { dose factors } \\
(\mathrm{mg} / \mathrm{kg} / \text { day })\end{array}$ & $\begin{array}{c}\text { Inhalation } \\
\text { reference } \\
\text { dose factors } \\
(\mathrm{mg} / \mathrm{kg} / \mathrm{day})\end{array}$ & $\begin{array}{c}\text { Oral } \\
\text { slope factors } \\
1 /(\mathrm{mg} / \mathrm{kg} / \text { day }) \\
\end{array}$ & $\begin{array}{c}\text { Inhalation } \\
\text { slope factors } \\
1 /(\mathrm{mg} / \mathrm{kg} / \mathrm{day}) \\
\end{array}$ \\
\hline \multicolumn{5}{|l|}{ ALUMINUM } \\
\hline ANTIMONY & $4.00 \mathrm{E}-04$ & & & \\
\hline ARSENIC & $1.00 \mathrm{E}-03^{b}$ & Withdrawn & $1.75 \mathrm{E}+00^{b}$ & $5.01 \mathrm{E}+01$ \\
\hline BARIUM & 5.00E-02 & & & \\
\hline BERYLLIUM & $5.00 \mathrm{E}-03$ & & $4.30 \mathrm{E}+00$ & $8.40 \mathrm{E}+00$ \\
\hline BORON & $9.00 \mathrm{E}-02$ & & & \\
\hline CADMIUM & 1.00E-03 & & & $6.10 \mathrm{E}+00$ \\
\hline CHROMIUM VI & $5.00 \mathrm{E}-03$ & & & 4.10E+01 \\
\hline COPPER & No information & & & \\
\hline CYANIDE & $2.00 \mathrm{E}-02$ & & & \\
\hline LEAD & Under review & & & \\
\hline MERCURY & $3.00 \mathrm{E}-04^{b}$ & & & \\
\hline \multicolumn{5}{|l|}{ MOLYBDENUM } \\
\hline NICKELC & $2.00 \mathrm{E}-02$ & & & $1.19 \mathrm{E}+00$ \\
\hline \multicolumn{5}{|l|}{ NIOBIUM } \\
\hline SELENIUM & 3.00E-03 & $1.00 \mathrm{E}-03$ & & \\
\hline SILVER & $3.00 \mathrm{E}-03$ & & & \\
\hline THALLIUMc & $7.00 \mathrm{E}-05^{b}$ & & & \\
\hline TIN & $6.00 \mathrm{E}-01^{b}$ & & & \\
\hline \multicolumn{5}{|l|}{ TITANIUM } \\
\hline URANIUMc & $3.00 \mathrm{E}-03$ & & 5.60E-06 & \\
\hline VANADIUM & $7.00 \mathrm{E}-03^{b}$ & & & \\
\hline ZINC & $2.00 \mathrm{E}-01^{b}$ & & & \\
\hline ZIRCONIUM & No information & & & \\
\hline
\end{tabular}

All entries from IRIS unless otherwise footnoted.

$a$ IRIS 1989. Integrated Risk Information System (data base), U.S. Environmental Protection Agency, Office of Research and Development, Washington, D.C., December.

$b$ USEPA 1989c. (U.S. Environmental Protection Agency). 1989c. Health Effects Assessment Summary Tables, Fourth Quarter, FY 1989. OERR 9200.6-303-(89-3). EPA Office of Water Regulations and Standards, Washington, D.C.

c Soluble salts. 
Table A2. Reference dose factors and slope (cancer potency) factors for organic chemicals $a$

\begin{tabular}{|c|c|c|c|c|}
\hline $\begin{array}{l}\text { Organic } \\
\text { Compound } \\
\end{array}$ & $\begin{array}{c}\text { Oral } \\
\text { reference } \\
\text { dose factors } \\
(\mathrm{mg} / \mathrm{kg} / \mathrm{day}) \\
\end{array}$ & $\begin{array}{l}\text { Inhalation } \\
\text { referenoe } \\
\text { dose ractors } \\
(\mathrm{mg} / \mathrm{kg} / \mathrm{day})\end{array}$ & $\begin{array}{c}\text { Oral } \\
\text { Blope factors } \\
1 /(\mathrm{mg} / \mathrm{kg} / \mathrm{day}) \\
\end{array}$ & $\begin{array}{c}\text { Inhalation } \\
\text { slope factors } \\
1 /(\mathrm{mg} / \mathrm{kg} / \text { day }) \\
\end{array}$ \\
\hline 1,1,1-TRICHLOROETHANE & 9.00E-02 & ' & & \\
\hline 1,1,2,2-TETRACHLOROETHANE & & & 2.00E-01 & \\
\hline 1,1,2-TRICHLOROETHANE & 4.00E-03 & & 5.70E-02 & \\
\hline 1,1-DICHLOROETHANE & $1.00 \mathrm{E}-01^{b}$ & & $9.10 \mathrm{E}-02^{b}$ & \\
\hline 1,1-DICHLOROETHYLENE & $9.00 \mathrm{E}-03$ & & $6.00 \mathrm{E}-01$ & \\
\hline 1,2,4-TRICHLOROBENZENE & $2.00 \mathrm{E}-02^{b}$ & & & \\
\hline 1,2,5,6-DIBENZANTHRACENE & & & $1.15 \mathrm{E}+01^{c}$ & \\
\hline 1,2-DICHLOROBENZENE & $9.00 \mathrm{E}-02$ & & & \\
\hline 1,2-DICHLOROETHANE & & & 9.10E-02 & \\
\hline 1,2-DICHLOROPROPANE & & & $6.80 \mathrm{E}-02^{b}$ & \\
\hline 1,2-DIPHENYLHYDRAZINE & & & $8.00 \mathrm{E}-01$ & \\
\hline \multicolumn{5}{|l|}{ 1,3-DICHLOROBENZENE } \\
\hline 1,3-DICHLOROPROPENE & $3.00 \mathrm{E}-04$ & & $1.80 \mathrm{E}-01^{b}$ & \\
\hline 1,4-DICHLOROBENZENE & & & $2.40 \mathrm{E}-02 b$ & \\
\hline 2,4,6-TRICHLOROPHENOL & & & $2.00 \mathrm{E}-02^{b}$ & \\
\hline 2,4-DICHLOROPHENOL & $3.00 \mathrm{E}-03$ & & & \\
\hline \multicolumn{5}{|l|}{ 2,4-DIMETHYLPHENOL } \\
\hline 2,4-DINITROPHENOL & $2.00 \mathrm{E}-03$ & & & \\
\hline 2,4-DINITROTOLUENE & & & $6.80 \mathrm{E}-01^{b}$ & \\
\hline 2,6-DINITROTOLUENE & & & $6.80 \mathrm{E}-01^{b}$ & \\
\hline \multicolumn{5}{|l|}{ 2-CHLOROETHYL VINYL ETHER } \\
\hline \multicolumn{5}{|l|}{ 2-CHLORONAPHTHALENE } \\
\hline 2.CHLOROPHENOL & $5.00 \mathrm{E}-03$ & & & \\
\hline \multicolumn{5}{|l|}{ 2-NITROPHENOL } \\
\hline 3,3'-DICHLOROBENZIDINE & & & $4.50 \mathrm{E}-01$ & \\
\hline 4,6-DINITRO-ORTHO-CRESOL & $1.00 \mathrm{E}-04 b$ & & & \\
\hline \multicolumn{5}{|l|}{ 4-BROMOPHENYL PHENYL ETHER } \\
\hline \multicolumn{5}{|l|}{ 4-CHLOROPHENYL PHENYL ETHER } \\
\hline \multicolumn{5}{|l|}{ 4-NITROPHENOL } \\
\hline ACENAPHTHENE & & & $1.15 E+01 c$ & \\
\hline ACENAPHTHYLENE & & & $1.15 \mathrm{E}+01 \mathrm{c}$ & \\
\hline ACROLEIN & $1.60 \mathrm{E}-02$ & & & \\
\hline ACRYLONITRILE & & & $5.40 \mathrm{E}-01$ & \\
\hline ALDRIN & $3.00 \mathrm{E}-05$ & & $1.70 \mathrm{E}+01$ & \\
\hline ALPHA BHC & & & $6.30 \mathrm{E}+00$ & \\
\hline ANTHRACENE & & & $1.15 \mathrm{E}+01^{c}$ & \\
\hline BENZENE & & & 2.90E-02 & \\
\hline
\end{tabular}


51

Table A2 (continued)

\begin{tabular}{|c|c|c|c|c|}
\hline $\begin{array}{l}\text { Organic } \\
\text { Compound }\end{array}$ & $\begin{array}{c}\text { Oral } \\
\text { reference } \\
\text { dose factors } \\
(\mathrm{mg} / \mathrm{kg} / \mathrm{day}) \\
\end{array}$ & $\begin{array}{l}\text { Inhalation } \\
\text { reference } \\
\text { dose ractorg } \\
(\mathrm{mg} / \mathrm{kg} / \mathrm{day}) \\
\end{array}$ & $\begin{array}{c}\text { Oral } \\
\text { slope factors } \\
1 /(\mathrm{mg} / \mathrm{kg} / \mathrm{day}) \\
\end{array}$ & $\begin{array}{c}\text { Inhalation } \\
\text { slope factors } \\
1 /(\mathrm{mg} / \mathrm{kg} / \text { day }) \\
\end{array}$ \\
\hline BENZIDINE & $3.00 \mathrm{E}-03$ & & $2.30 \mathrm{E}+02$ & \\
\hline BENZO(A)ANTHRACENE & & & $1.15 \mathrm{E}+01 \mathrm{c}$ & \\
\hline BENZO(B)FLUORANTHENE & & & $1.15 \mathrm{E}+01^{c}$ & \\
\hline BENZO(GHI)PERYLENE & & & $1.15 \mathrm{E}+01 c$ & \\
\hline BENZO(K) FLUORANTHENE & & & $1.15 \mathrm{E}+01 c$ & \\
\hline BENZO-A-PYRENE & & & $1.15 \mathrm{E}+01^{c}$ & \\
\hline BETA BHC & & & $1.80 E+00$ & \\
\hline \multicolumn{5}{|l|}{ BIS (2-CHLOROETHOXY) METHANE } \\
\hline BIS (2-CHLOROETHYL) ETHER & & & $1.10 \mathrm{E}+\infty$ & \\
\hline BIS (2-CHLOROISOPROPYL) ETHER & $4.00 \mathrm{E}-02$ & & & \\
\hline BIS (2-ETHYLHEXYL) PHTHALATE & $2.00 \mathrm{E}-02$ & & $1.40 \mathrm{E}-02$ & \\
\hline BIS (CHLOROMETHYL) ETHER & & & $2.20 \mathrm{E}+02$ & \\
\hline BROMOFORM & $2.00 \mathrm{E}-02$ & & $7.90 \mathrm{E} \cdot 03$ & \\
\hline BUTYLBENZYLPHTHALATE & $2.00 \mathrm{E}-01$ & & & \\
\hline CARBON TETRACHLORIDE & $7.00 \mathrm{E}-04$ & & $1.30 \mathrm{E}-01$ & \\
\hline CHLORDANE & $6.00 \mathrm{E}-05$ & & $1.30 \mathrm{E}+00$ & \\
\hline CHLOROBENZENE & 2.00E-02 & & & \\
\hline CHLORODIBROMOMETHANE & 2.00E-02 & & $8.40 \mathrm{E}-02^{b}$ & \\
\hline \multicolumn{5}{|l|}{ CHLOROETHANE } \\
\hline CHLOROFORM & 1.00E-02 & & $6.10 \mathrm{E}-03$ & \\
\hline CHRYSENE & & & $1.15 \mathrm{E}+0 \%$ & \\
\hline CIS-1 3-DICHLOROPROPENE & $3.00 \mathrm{E} \cdot 04$ & & & \\
\hline \multicolumn{5}{|l|}{ DELTA BHC } \\
\hline DI-N-BUTYL PHTHALATE & $1.00 \mathrm{E}-01$ & & & \\
\hline \multicolumn{5}{|l|}{ DI-N-OCTYL PHTHALATE } \\
\hline DIBENZ(A H)ANTHRACENE & & & $1.15 \mathrm{E}+01 \mathrm{c}$ & \\
\hline DICHLOROBROMOMETHANE & $2.00 \mathrm{E}-02^{b}$ & & $1.30 \mathrm{E}-01^{b}$ & \\
\hline DICHLORODIFLUOROMETHANE & 2.00E-01 & & & \\
\hline DIELDRIN & $5.00 \mathrm{E}-05$ & & $1.60 \mathrm{E}+01$ & \\
\hline DIETHYL PHTHALATE & $8.00 \mathrm{E}-01$ & & & \\
\hline \multicolumn{5}{|l|}{ DIMETHYL PHTHALATE } \\
\hline \multicolumn{5}{|l|}{ ENDOSULFAN SULFATE } \\
\hline ENDOSULFAN, ALPHA & $5.00 \mathrm{E}-05$ & & & \\
\hline ENDOSULFAN, BETA & $5.00 \mathrm{E}-05$ & & & \\
\hline ENDRIN & 3.00E-04 & & & \\
\hline \multicolumn{5}{|l|}{ ENDRIN ALDEHYDE } \\
\hline ETHYLBENZENE & $1.00 \mathrm{E}-01$ & & & \\
\hline FLUORANTHENE & & & $1.15 \mathrm{E} \div 01 \mathrm{c}$ & \\
\hline
\end{tabular}


Table A2 (continued)

\begin{tabular}{|c|c|c|c|c|}
\hline $\begin{array}{l}\text { Organic } \\
\text { Compound } \\
\end{array}$ & $\begin{array}{c}\text { Oral } \\
\text { reference } \\
\text { dose factors } \\
\text { (mg/kg/day) } \\
\end{array}$ & $\begin{array}{c}\text { Inhalation } \\
\text { reference } \\
\text { dose ractors } \\
(\mathrm{mg} / \mathrm{kg} / \mathrm{day}) \\
\end{array}$ & $\begin{array}{c}\text { Oral } \\
\text { slope factors } \\
1 /(\mathrm{mg} / \mathrm{kg} / \mathrm{day}) \\
\end{array}$ & $\begin{array}{c}\text { Inhalation } \\
\text { slope factors } \\
1 /(\mathrm{mg} / \mathrm{kg} / \mathrm{day}) \\
\end{array}$ \\
\hline FLUORENE & & & $1.15 \mathrm{E}+01 \mathrm{c}$ & \\
\hline GAMMA-BHC(LINDANE) & & & $1.30 \mathrm{E}+00 b$ & \\
\hline HEPTACHLOR & $5.00 \mathrm{E}-04$ & & $4.50 \mathrm{E}+00$ & \\
\hline HEPTACHLOR EPOXIDE & 1.30E-05 & & $9.10 \mathrm{E}+00$ & \\
\hline HEXACHLOROBENZENE & $8.00 \mathrm{E}-04$ & & $1.70 \mathrm{E}+00 b$ & \\
\hline HEXACHLOROBUTADIENE & $2.00 \mathrm{E}-03$ & & $7.80 \mathrm{E}-02$ & \\
\hline HEXACHLOROCYCLOPENTADIENE & $7.00 \mathrm{E}-03$ & & & \\
\hline HEXACHLOROETHANE & $1.00 \mathrm{E}-03$ & & $1.40 \mathrm{E}-02$ & \\
\hline INIDENO (1,2,3-CD) PYRENE & & & $1.15 \mathrm{E}+01^{\mathrm{c}}$ & \\
\hline ISOPHORONE & $2.00 \mathrm{E}-01$ & & $4.13 \mathrm{E}-03 b$ & \\
\hline METHYL BROMIDE & $1.40 \mathrm{E}-03 b$ & & & \\
\hline METHYL CHLORIDE & & & $1,30 \mathrm{E}-02 b$ & \\
\hline METHYLENE CHLORIDE & $6.00 \mathrm{E}-02$ & & $7.50 \mathrm{E}-03$ & \\
\hline N-BUTYL BENZYL PHTHALATE & $2.00 \mathrm{E}-01$ & & & \\
\hline N-NITROSODI-N-PROPYLAMINE & & & $7.00 \mathrm{E}+00$ & \\
\hline N-NITROSODIMETHYLAMINE & & & $5.10 \mathrm{E}+01$ & \\
\hline N-NITROSODIPHENYLAMINE & & & $4.90 \mathrm{E}-03$ & \\
\hline NAPHTHALENE & $4.00 \mathrm{E}-01^{b}$ & & & \\
\hline NITROBENZENE & $5.00 \mathrm{E}-04$ & & & \\
\hline P,P'DDD & & & $2.40 \mathrm{E}-01$ & \\
\hline P,P'DDE & & & $3.40 \mathrm{E}-01$ & \\
\hline P,P'DDT & $5.00 \mathrm{E}-04$ & & $3.40 \mathrm{E}-01 b$ & \\
\hline \multicolumn{5}{|l|}{ PARACHLOROMETA CRESOL } \\
\hline PCB-1254 (AROCLOR 1254)* & & & $7.70 E+00$ & \\
\hline PCB.1260 (AROCLOR 1260)* & & & $7.70 E+\infty$ & \\
\hline PENTACHLOROPHENOL & $3.00 \mathrm{E}-02$ & & & \\
\hline PHENANTHRENE & & & $1.15 \mathrm{E}+01^{c}$ & \\
\hline PHENOL & $6.00 \mathrm{E}-01$ & & & \\
\hline PYRENE & & & $1.15 \mathrm{E}+01^{\mathrm{c}}$ & \\
\hline TETRACHLOROETHYLENE & $1.00 \mathrm{E}-02$ & & $5.10 \mathrm{E}-02 b$ & \\
\hline TOLUENE & 3.00E-01 & & & \\
\hline TOXAPHENE & & & $1.10 \mathrm{E}+00$ & \\
\hline TRANS-1 3-DICHLOROPROPENE & $3.00 \mathrm{E}-04$ & & $1.80 \mathrm{E}-01 b$ & \\
\hline TRANS-1,2-DICHLOROETHENE & $2.00 \mathrm{E}-02$ & & & \\
\hline TRICHLOROETHYLENE & & & $1.10 \mathrm{E}-02 b$ & \\
\hline TRICHLOROFLUOROMETHANE & 3.00E-01 & & & \\
\hline VINYL CHLORIDE & & & $2.30 \mathrm{E}+00$ & \\
\hline
\end{tabular}


Table A2 (continued)

All entries from IRIS unless otherwise footnoted.

a IRIS 1989. Integrated Risk Information System (data base), U.S. Environmental Protection Agency, Office of Research and Development, Washington, D.C., December.

$b$ USEPA. (U.S. Environmental Protection Agency). 1989c. Health Effects Assessment Summary Tables, Fourth Quarter, FY 1989. OERR 9200.6-303-(89-3). EPA Office of Water Regulations and Standards, Washington, D.C.

c USEPA (U.S. Environmental Protection Agency). 1986. Quality Criteria for Water, May 1, 1987 update. EPA 440/5-86-001. EPA Office of Water Regulations and Standards, Washington, D.C. 
Table A3. Dose conversion factors for radionuclidesab

\begin{tabular}{|c|c|c|c|}
\hline Radionuclide & $\begin{array}{c}\text { Ingestion } \\
(\mathrm{Sv} / \mathrm{Bq})\end{array}$ & $\begin{array}{c}\text { Inhalation } \\
(\mathrm{Sv} / \mathrm{Bq})\end{array}$ & $\begin{array}{c}\text { Extornal } \\
(\mathrm{Sv} / \mathrm{d}) /\left(\mathrm{Bq} / \mathrm{m}^{2}\right) \\
\end{array}$ \\
\hline$A m-241$ & $5.94 \mathrm{E} \times 07$ & $1,43 \mathrm{E}-04$ & $2,26 \mathrm{~L}-12$ \\
\hline $\mathrm{Cm}-244$ & $3.13 \mathrm{E}-07$ & $7.61 \mathrm{~L}-05$ & $6.63 \mathrm{E}-14$ \\
\hline $\mathrm{Co} \cdot 60$ & $7.28 \mathrm{E}-09$ & 5.91.E-08 & $1.71 \mathrm{E} \cdot 10$ \\
\hline $\mathrm{Cs}-134$ & $1,98 \mathrm{E}-08$ & $1,25 \mathrm{E}-08$ & $1.19 \mathrm{E}-10$ \\
\hline Cs-137 & $1.36 \mathrm{E}-08$ & $8.63 \mathrm{E}-09$ & $\$, 41 \mathrm{E}-11$ \\
\hline $\mathrm{Eu}-152$ & $1.75 \mathrm{E}-09$ & $5.97 \mathrm{E}-08$ & $8,41 \mathrm{E} \cdot 11$ \\
\hline Eu-154 & $2.68 \mathrm{E}-09$ & $7.73 \mathrm{E} \cdot 08$ & $9.17 \mathrm{E}-11$ \\
\hline $\mathrm{H}-3$ & $1.70 \mathrm{E}-11$ & $1.70 \mathrm{E}-11$ & \\
\hline Np.237 & $1.07 \mathrm{E}-05$ & $1.35 \mathrm{E}-04$ & $2.45 \mathrm{E}-12$ \\
\hline $\mathrm{Pa}-233$ & $9.81 \mathrm{E}-10$ & $2.58 \mathrm{E}-09$ & $1.77 \mathrm{E} \backsim 11$ \\
\hline $\mathrm{Pa}-234$ & $5.84 \mathrm{E}-10$ & $2.20 \mathrm{E}-10$ & $1,48 \mathrm{E}-10$ \\
\hline $\mathrm{Pu}-238$ & $1.07 \mathrm{E}-07$ & $1.25 \mathrm{E}-04$ & $6.87 \mathrm{E}-14$ \\
\hline Pu-239 & $1.19 \mathrm{E}-07$ & $1.40 \mathrm{E} \cdot 04$ & $3.01 \mathrm{E} \cdot 14$ \\
\hline Sr-89 & $2.60 \mathrm{E}-09$ & $1.12 \mathrm{E}-08$ & $4.38 \mathrm{E}-12$ \\
\hline Sr.90 & $3.85 \mathrm{E}-08$ & $3.51 \mathrm{E}-07$ & \\
\hline Tc-99 & $3.95 \mathrm{E}-10$ & $2.25 \mathrm{E}-09$ & $4.68 \mathrm{E}-17$ \\
\hline Th-232 & $7.38 \mathrm{E}-07$ & $4,43 \mathrm{E}-04$ & $5.28 \mathrm{E} \cdot 14$ \\
\hline Th-234 & $3.68 \mathrm{E}-09$ & 9.47E-09 & $7.58 \mathrm{E}-13$ \\
\hline U.234 & $7.66 \mathrm{E}-08$ & $3.58 \mathrm{E}-05$ & $1.35 \mathrm{E}-13$ \\
\hline U-235 & $7.19 \mathrm{E}-08$ & $3.32 \mathrm{E}-05$ & $1.44 \mathrm{E}-11$ \\
\hline U-236 & $7.26 \mathrm{E}-08$ & $3.39 \mathrm{E}-05$ & $5.86 \mathrm{E}-14$ \\
\hline U.238 & $6.88 \mathrm{E}-08$ & $3.20 \mathrm{E}-05$ & $8.12 \mathrm{E}-12$ \\
\hline
\end{tabular}
products.

a Dose factors are effective dose equivalents and include the contribution of daughter

6 Dose conversion fuctors developed for NCRP for screening purposes by K. F. Eckerman of ORNL (see footnote 1 Section 2.1). 
Appendix B

MAXIMUM AND MEAN CONCENTRATIONS OF ORGANIC AND INORGANIC CHEMICAIS AND RADIONUCLIDES IN SEDIMENT, FISH, AND WATER. FOR EACH STREAM REACH 
Table B1. Maximum concentrations of inorganic compounds in sediment, fish, and water

\begin{tabular}{|c|c|c|c|c|c|c|}
\hline Roach & $\begin{array}{l}\text { Inorganlo } \\
\text { Compound }\end{array}$ & & $\begin{array}{l}\text { Bodiment } \\
\left(\mathrm{mg} / \mathrm{kg} \mathrm{g}_{1} \text { dry }\right)\end{array}$ & $\begin{array}{c}\text { Figh } \\
\text { (mg/kg, wat) }\end{array}$ & & $\begin{array}{l}\text { Water } \\
(\mathrm{mg} / \mathrm{L})\end{array}$ \\
\hline 1 & ANTIMONY & & $9.00 \mathrm{D} .01$ & $1.00 \mathrm{E}+00$ & & \\
\hline 1 & ARSENIC & & $1.70 \mathrm{E}+01$ & $4,20 \mathrm{D} \cdot 01$ & & 3,60 [I]-01 \\
\hline 1 & BERYLLIUM & & $1.60 \mathrm{E}+00$ & 0.06 & & \\
\hline 1 & OADMIUM & & $5,000.01$ & $1,40 \mathrm{E} \cdot 01$ & $<$ & $6,00 \mathrm{D}-03$ \\
\hline 1 & CHIROMIUM & & $2.70 \mathrm{E}+01$ & $3.60 \mathrm{E}-0 . \mathrm{L}$ & & $2.10 \mathrm{M} .02$ \\
\hline 1 & OOPPER & & $5.40 \mathrm{E}+01$ & $2.80 \mathrm{E}+00$ & & $5.70 \mathrm{E} .02$ \\
\hline 1 & CYANIDD & & 4.00区.01 & & & \\
\hline 1 & LEAD & & $4,60 \mathbb{E}+01$ & $1.60 \mathrm{E}+010$ & $<$ & $2.00 \mathrm{E}-02$ \\
\hline 1 & MEROURY, TOTAL & & $1.00 \mathrm{E} \cdot 01$ & 4.40E.01 & & $5,20 \mathrm{D}-03$ \\
\hline 1 & NICKTLL & & $3.60 \mathrm{E}+01$ & $1.00 \mathrm{E}+00$ & & $2,00 \mathrm{E}-02$ \\
\hline 1. & SELENIUM & & $2.00 \mathrm{E}+00$ & $1,80 \mathrm{E}+00$ & & $3.20 \mathrm{H} \times 02$ \\
\hline 1 & SILVER & $<$ & $1.00 \mathrm{E}+00$ & $7.00 \mathrm{E}-01$ & & \\
\hline 1 & THLALLIUM & $<$ & $5.00 \mathrm{E}+00$ & $3,80 E+00$ & & \\
\hline 1 & URANIUM & & $5.80 \mathrm{E}+00$ & & & \\
\hline 1 & ZINC & & $1.60 \mathrm{E}+02$ & $1.10 \mathrm{E}+101$ & & $2.80 \mathrm{E}-02$ \\
\hline 1 & ZIRCONIUM & & $2.30 \mathrm{E}+02$ & & $<$ & $2.00 \mathrm{E} .03$ \\
\hline 2 & ALUMINUM & & $1.002+04$ & & & $1.70 \mathrm{w}+01$ \\
\hline 2 & ANTIMONY & & & $1.00 \mathrm{E}+00$ & & \\
\hline 2 & ARSENIC & & $1.20 \mathrm{E}+01$ & $4.00 \mathrm{E}-0.1$ & & $9.00 \mathrm{E} \cdot 01$ \\
\hline 2 & BERYLLIUM & & & $4.00 \mathrm{E} \cdot(12$ & & \\
\hline 2 & CADMIUM & & $4.20 \mathrm{E}+00$ & $4.0000 \cdot 02$ & & $3.00 \mathrm{DD} .03$ \\
\hline 2 & OHIROMIUM & & $2.90 \mathrm{D}+02$ & $3.60 \mathrm{E}-01$ & & $9.30 \mathrm{E}-02$ \\
\hline 2 & COPPER & & $1.70 \mathrm{E}+01$ & $1.00 \mathrm{E}+01$ & & 1.30区-01 \\
\hline 2 & CYANIDE & $<$ & $1.00 E+00$ & & & $2.60 \mathrm{E}-02$ \\
\hline 2 & LEAD & & $5.10 \mathrm{E}+01$ & B.00E -01 & & $1.90 \mathrm{E}-02$ \\
\hline 2 & MERCURY, TOTAL & $A$ & $6.00 E+00$ & 5.600 .01 & & $4.00 \mathrm{E}-04$ \\
\hline 2 & NICKDL & & $3.00 \mathrm{E}+01$ & $1.00 \mathrm{E}+(100$ & & $7.70 \mathrm{E} .02$ \\
\hline 2 & SELENIUM & & $1.10 \mathrm{E}+02$ & $4.10 \mathrm{E}-0.1$ & & \\
\hline 2 & SI,VER & & $1.00 \mathrm{E}+01$ & $5,00 \mathrm{E} \cdot 01$ & $<$ & $5.00 \mathrm{E}-03$ \\
\hline 2 & THLALLIUM & & & $1.00 \mathrm{E}+00$ & & \\
\hline 2 & URANIUM & & $1.80 \mathrm{E}+01$ & & & \\
\hline 2 & ZINC & & $9.20 \pi+01$ & $1.10 \mathrm{E}+01$ & & $1.80 \mathrm{E}-01$ \\
\hline 2 & ZIRCONIUM & & $8.90 \mathrm{E}+02$ & & & \\
\hline 3 & ALUUMINUM & & $1.40 \mathrm{E}+0.5$ & & & $1.20 \mathrm{E}+01$ \\
\hline 3 & AÑTYMONY & & & $1.00 \mathrm{E}+00$ & & $2.70 \mathrm{E}-01$ \\
\hline 3 & ARSENIC & & $6.80 \mathrm{E}+01$ & $6.00 \mathrm{E} \cdot 0.1$ & & $2.10 \mathrm{~W}-02$ \\
\hline 3 & BARIUM & & & & $<$ & $1.00 \mathrm{E}-01$ \\
\hline 3 & BERYLLIUM & & & $4.0 \mathrm{E}-02$ & & $2.40 \mathrm{E}-03$ \\
\hline 3 & BORON & & & & & $1.20 \mathrm{E}+01$ \\
\hline 3 & CADMIUM & & $3.50 \mathrm{E}+00$ & $2.00 \mathrm{E} \cdot 02$ & & 5.00E.02 \\
\hline
\end{tabular}


Table B1 (continuod)

\begin{tabular}{|c|c|c|c|c|c|c|c|}
\hline Reauh & $\begin{array}{l}\text { Inorganle } \\
\text { Compound }\end{array}$ & & $\begin{array}{l}\text { Sodiment } \\
\text { (mg/kg, dry) }\end{array}$ & & $\begin{array}{c}\text { Flsh } \\
(\mathrm{mg} / \mathrm{kg}, \text { wet })\end{array}$ & & $\begin{array}{l}\text { Wator } \\
(\mathrm{mg} / \mathrm{L})\end{array}$ \\
\hline 3 & CHROMIUM & & $2.70 \mathrm{E}+02$ & & B.90E-01 & & $4.10 \mathrm{E} \cdot 02$ \\
\hline 3 & COPPEER & & $2,60 \mathrm{E}+02$ & & $4.10 \mathrm{D}+00$ & & $4.10 \mathrm{~L} \cdot 01$ \\
\hline 3 & CYANIDE & $<$ & $1.10 E+00$ & & & & $1.98 \mathrm{E} .01$ \\
\hline 3 & LEAD & & $8.40 \mathrm{E}+01$ & & $3.60 \mathrm{E}-01$ & & $2.10 \mathrm{E} .01$ \\
\hline 3 & MERCURY, TOTAL & & $5.90 \mathrm{E}+00$ & & $1.70 \mathrm{E}+00$ & & $1.00 \mathrm{E} .03$ \\
\hline$y$ & MOLYBDENUM & & & & & & 4.00E-02 \\
\hline 3 & NICKEL & & $1.30 \mathrm{E}+03$ & & $2.00 \mathrm{E}+00$ & & $1.60 \mathrm{E}+00$ \\
\hline 3 & NIOBIUM & & & & & & $3.00 \mathrm{E} \cdot 02$ \\
\hline 3 & SELENIUM & & $1.60 \mathrm{E}+02$ & & $5.00 \mathrm{E} \cdot 01$ & $<$ & $5.00 \mathrm{E}-02$ \\
\hline 3 & SILVER & & $2.00 E+00$ & & $6.00 \mathrm{E}-01$ & & $2.60 \mathrm{E}-02$ \\
\hline 3 & THALLIUM & & & & $1.00 E+00$ & & \\
\hline 3 & TIN & & & & & & 3.00E-02 \\
\hline 3 & TITANIUM & & & & & & $5.40 \mathrm{E}-02$ \\
\hline 3 & URANIUM & & $1.79 \Sigma+02$ & & & & $4.94 \mathrm{E}+00$ \\
\hline 3 & VANADIUM & & & & & $<$ & $5.00 \mathrm{E}-01$ \\
\hline$\theta$ & ZINC & & $3.70 \mathrm{E}+02$ & & $1.60 \mathrm{E}+01$ & & $1.00 \mathrm{E}+00$ \\
\hline 3 & ZIRCONIUM & & $4.70 \mathrm{E}+02$ & & & & $2.80 \mathrm{E} \times 02$ \\
\hline 4 & ALUMINUM & & $8.15 E+04$ & & & & \\
\hline 4 & ANTIMONY & & & $<$ & $1.00 E+00$ & & \\
\hline 4 & ARSENIC & & $1.10 \mathrm{E}+01$ & & $4.00 \mathrm{E}-01$ & & $5.40 \mathrm{E} .03$ \\
\hline 4 & BARIUM & & $4.71 \mathrm{E}+02$ & & & & \\
\hline 4 & BERYLIIUM & & $2,68 \mathrm{E}+40$ & $<$ & $1.00 \mathrm{E}-01$ & & \\
\hline 4 & BORON & & $3.10 \mathrm{E}+02$ & & & & \\
\hline 4 & CADMIUM & & $1.60 \mathrm{E}+00$ & & $2.00 \mathrm{E}-02$ & & $3.00 \mathrm{E}-03$ \\
\hline 4 & CHROMIUM & & $9.04 E+01$ & & $8.20 \mathrm{E}-01$ & & $7.70 \mathrm{E}-02$ \\
\hline 4 & COPPER & & $6.57 \mathrm{E}+01$ & & $5.60 \mathrm{E} .01$ & & $3.00 \mathrm{E} \cdot 02$ \\
\hline 4 & CYANIDE & $<$ & $8.00 \mathrm{E} \cdot 01$ & & & & \\
\hline 4 & LEAD & & $1.30 \mathrm{E}+02$ & & 4.60E-01 & & $2.60 \mathrm{E}-02$ \\
\hline 4 & MERCURY, TO'TAL & & $4.70 \mathrm{E}+.01$ & & $1.20 \mathrm{E}+00$ & & $6.00 \mathrm{E}-04$ \\
\hline 4 & NICKEL & & $5.8 \mathrm{CE}+01$ & & $1.00 \mathrm{E}+00$ & & $7.40 \mathrm{E}-02$ \\
\hline 4 & SELENIUM & & $1.90 \mathrm{E}+02$ & & $2.60 \mathrm{E}+00$ & & \\
\hline 4 & SLVER & & $3.70 \mathrm{E}+00$ & $<$ & $2.00 \mathrm{E}, 01$ & & \\
\hline 4 & THALLIUM & & & $<$ & $1.0 \mathrm{E}+00$ & & \\
\hline 4 & TITANIUM & & $4.08 \mathrm{E}+03$ & & & & \\
\hline 4 & URANIUM & & $7.82 \mathrm{E}+00$ & & & & \\
\hline 4 & VANADIJMI & & $9.90 E+01$ & & & & \\
\hline 4 & ZINC & & $1.68 \mathrm{E}+02$ & & $1.70 \mathrm{E}+01$ & & $2.40 \mathrm{E}-01$ \\
\hline 4 & ZIRCOIVIUM & & $6.10 \mathrm{E}+02$ & & & & \\
\hline 5 & ARSENIC & & $1.60 \mathrm{E}+01$ & & $2.00 \mathrm{E}-01$ & & \\
\hline 5 & BERYLLIUM & & $1.60 \mathrm{E}+00$ & & & & \\
\hline 5 & CADMIUM & $<$ & $1.00 \mathrm{E}+00$ & & $5.00 \mathrm{E}-02$ & & \\
\hline
\end{tabular}


Table B1 (continued)

\begin{tabular}{|c|c|c|c|c|c|c|c|}
\hline Reach & $\begin{array}{l}\text { Inorganic } \\
\text { Compound } \\
\end{array}$ & & $\begin{array}{c}\text { Sediment } \\
\text { (mg/kg, dry) }\end{array}$ & & $\begin{array}{c}\text { Fish } \\
(\mathrm{mg} / \mathrm{kg} \text {, wet) }\end{array}$ & & $\begin{array}{l}\text { Water } \\
(\mathrm{mg} / \mathrm{L}) \\
\end{array}$ \\
\hline 5 & CHROMIUM & & $5.40 \mathrm{E}+01$ & & $9.80 \mathrm{E} \cdot 01$ & & \\
\hline 5 & COPPER & & $4.00 \mathrm{E}+01$ & & & $<$ & $1.00 \mathrm{E}-02$ \\
\hline 5 & LEAD & & $5.30 \mathrm{E}+01$ & & & & \\
\hline 5 & MERCURY, TOTAL & & $2.44 E+01$ & & $1.80 \mathrm{E}-01$ & & \\
\hline 5 & NICKEL & & $2.40 \mathrm{E}+01$ & $<$ & $1.00 \mathrm{E}+00$ & & \\
\hline 5 & SELENIUM & & $8.00 \mathrm{E}-01$ & & & & \\
\hline 5 & SILVER & $<$ & $1.00 \mathrm{E}+00$ & $<$ & $2.00 \mathrm{E}-01$ & & \\
\hline 5 & ZINC & & $2.20 \mathrm{E}+02$ & & & $<$ & $1.00 \mathrm{E}-02$ \\
\hline 10 & ARSENIC & & $2.40 \mathrm{E}+01$ & & & & \\
\hline 10 & CADMIUM & $<$ & $5.00 \mathrm{E}-01$ & & & & \\
\hline 10 & CHIROMIUM & & $2.30 E+01$ & & & & \\
\hline 10 & CYANIDE & $\dot{x}$ & 9.00E-01 & & & & \\
\hline 10 & LEAD & & $6.70 \mathrm{E}+01$ & & & & \\
\hline 10 & MERCURY, TOTAL & & $1.00 \mathrm{E}-01$ & & & & \\
\hline 10 & NICKEL & & $2.70 \mathrm{E}+01$ & & & & \\
\hline 10 & SILVER & $<$ & $1.00 \mathrm{E}+00$ & & & & \\
\hline 10 & URANIUM & & $4.30 \mathrm{E}+00$ & & & & \\
\hline 10 & ZIRCONIUM & & $2.10 \mathrm{E}+02$ & & & & \\
\hline 13 & ARSENIC & & & & & & $1.40 \mathrm{E}-02$ \\
\hline 13 & CADMIUM & & & & & $<$ & $2.00 \mathrm{E}-03$ \\
\hline 13 & CHROMIUM & & & & & $<$ & $1.00 \mathrm{E}-02$ \\
\hline 13 & COPPER & & & & & & $1.50 \mathrm{E}-02$ \\
\hline 13 & CYANIDE & & & & & & $3.00 \mathrm{E}-02$ \\
\hline 13 & LEAD & & & & & & $1.80 \mathrm{E}-02$ \\
\hline 13 & MERCURY & & & & & $<$ & $2.00 \mathrm{E}-04$ \\
\hline 13 & NICKEL & & & & & & $7.60 \mathrm{E}-02$ \\
\hline 13 & ZINC & & & & & & $1.00 \mathrm{E}-01$ \\
\hline 18 & ARSENIC & & & & $3.00 \mathrm{E}-01$ & & \\
\hline 18 & CADMIUM & & & & $1.00 \mathrm{E}-02$ & & \\
\hline 18 & CHROMIUM & & & & $9.00 \mathrm{E}-01$ & & \\
\hline 18 & MERCURY & & & & 4.50E-01 & & \\
\hline 18 & NICKEL & & & $<$ & $1.00 \mathrm{E}+00$ & & \\
\hline 18 & SILVER & & & $<$ & $2.00 \mathrm{E}-01$ & & \\
\hline
\end{tabular}

$A=$ duplicate samples averaged.

$<=$ below the limit of detection. 
Table B2. Maximum concentrations of organic chemicals in sediment, fish, and water

\begin{tabular}{|c|c|c|c|c|c|c|}
\hline Roach & $\begin{array}{l}\text { Inorganic } \\
\text { Compound } \\
\end{array}$ & & $\begin{array}{c}\text { Sodimont } \\
(\mathrm{mg} / \mathrm{kg}, \mathrm{dry})\end{array}$ & & $\begin{array}{c}\text { Fish } \\
(\mathrm{mg} / \mathrm{kg} \text {, wot) } \\
\end{array}$ & $\begin{array}{l}\text { Wator } \\
(\mathrm{mg} / \mathrm{L}) \\
\end{array}$ \\
\hline 1 & 1,1,1-TRICHLOROETHANE & $<$ & 8.00E-03 & $<$ & $5.00 \mathrm{E}-02$ & \\
\hline 1 & 1,1,2,2-TETRACHLOROETHANE & $<$ & $8.00 \mathrm{E}-03$ & $<$ & $5.00 \mathrm{E}-02$ & \\
\hline 1 & 1,1,2-TRICHLOROETHANE & $<$ & $8.00 \mathrm{E}-03$ & $<$ & $5.00 \mathrm{E}-02$ & \\
\hline 1 & 1,1-DICHLOROETHANE & $<$ & $8.00 \mathrm{E}-03$ & $<$ & $5.00 \mathrm{E}-02$ & \\
\hline 1 & 1,1-DICHLOROETHYLENE & $<$ & 8.00E-03 & $<$ & $5.00 \mathrm{E} \backsim 02$ & \\
\hline 1 & 1,2,4-TRICHLOROBENZENE & $<$ & $2.00 \mathrm{E}+00$ & $<$ & $3.30 \mathrm{E}+00$ & \\
\hline 1 & 1,2,5,6-DIBENZANTHRACENE & $<$ & $2.00 \mathrm{E}+00$ & $<$ & $3.30 \mathrm{E}+00$ & \\
\hline 1 & 1,2-DICHLOROBENZENE & $<$ & $2.00 \mathrm{E} 4.00$ & $<$ & $3.30 \mathrm{E}+00$ & \\
\hline 1 & 1,2-DICHLOROETHLANE & $<$ & $8.00 \mathrm{E}-03$ & $<$ & $5.00 \mathrm{E}-02$ & \\
\hline 1 & 1,2-DICHLOROPROPANE & $<$ & 8.00E-03 & $<$ & $5.00 \mathrm{E}-02$ & \\
\hline 1 & 1,2-DIPHENYLHYDRAZINE & $<$ & $2.00 \mathrm{E}+00$ & $<$ & $3.30 \mathrm{E}+00$ & \\
\hline 1 & 1,3-DICHLOROBENZENE & $<$ & $2.00 \mathrm{E}+00$ & $<$ & $3.30 \mathrm{E}+00$ & \\
\hline 1 & 1,3.DICHLOROPROPENE & $<$ & 8.00E-03 & $<$ & $5.00 \mathrm{E}-02$ & \\
\hline 1 & 1,4-DICHLOROBENZENE & $<$ & $2.00 \mathrm{E}+00$ & $<$ & $3.30 \mathrm{E}+00$ & \\
\hline 1 & 2,4,6-TRICHLOROPHENOL & $<$ & $5.00 \mathrm{E}-01$ & $<$ & $3.30 \mathrm{E}+00$ & \\
\hline 1 & 2,4-DICHLOROPHENOL & $<$ & $5.00 \mathrm{E}-01$ & $<$ & $3.30 \mathrm{E}+00$ & \\
\hline 1 & 2,4-DIMETHYLPIENOL & $<$ & $5.00 \mathrm{E}-01$ & $<$ & $3.30 \mathrm{E}+00$ & \\
\hline 1 & 2,4-DINI'TROPHENOL & $<$ & $5.00 \mathrm{E}+00$ & $<$ & $3.30 \mathrm{E}+01$ & \\
\hline 1 & 2,4-DINITROTOLUENE & $<$ & $2.00 \mathrm{E}+00$ & $<$ & $3.30 \mathrm{E}+00$ & \\
\hline 1 & 2,6-DINITROTOLUENE & $<$ & $2.00 \mathrm{E}+00$ & $<$ & $3.30 \mathrm{E}+00$ & \\
\hline 1 & 2-CHIOROETHYL VINYL ETHER & $<$ & $8.00 \mathrm{E}-03$ & $<$ & 5.00E-02 & \\
\hline 1 & 2-CHLORONAPHTHALENE & $<$ & $2.00 \mathrm{E}+00$ & $<$ & $3.30 \mathrm{E}+00$ & \\
\hline 1 & 2-CHLOROPHENOL & $<$ & $5.00 \mathrm{E}-01$ & $<$ & $3.30 \mathrm{E}+00$ & \\
\hline 1 & 2-NITROPHENOL & $<$ & $5.00 \mathrm{E}-01$ & $<$ & $3.30 E+00$ & \\
\hline 1 & 3,3-DICHLOROBENZIDINE & $<$ & $5,00 \mathrm{E}+00$ & $<$ & $8.20 \mathrm{E}+00$ & \\
\hline 1 & 4,6-DINITRO-ORTHO-CRESOL & $<$ & $2.50 \mathrm{E}+\infty 0$ & $<$ & $1.60 \mathrm{E}+01$ & \\
\hline 1 & 4-BROMOPHENYL PHENYL ETHER & $<$ & $2.00 \mathrm{E}+00$ & $<$ & $3.30 \mathrm{E}+00$ & \\
\hline 1 & 4-CHLOROPHENYL PHENYL ETHER & $<$ & $2.00 \mathrm{E}+00$ & $<$ & $3.30 \mathrm{E}+00$ & \\
\hline 1 & 4-NITROPHENOL & $<$ & $5.00 \mathrm{E}-01$ & $<$ & $3.30 \mathrm{E}+00$ & \\
\hline 1 & ACENAPHTHENE & $<$ & $2.00 E+00$ & $<$ & $3.30 \mathrm{E}+00$ & \\
\hline 1 & ACENAPHTHYLENE & $<$ & $2.00 \mathrm{E}+00$ & $<$ & $3.30 \mathrm{E}+00$ & \\
\hline 1 & ACROLEIN & $<$ & $8.00 \mathrm{E}-02$ & $<$ & $5.00 \mathrm{E}-02$ & \\
\hline 1 & ACRYLONITRILE & $<$ & 8.00E-02 & $<$ & 5.00E-02 & \\
\hline 1 & ALDRIN & $<$ & $5.00 \mathrm{E}-01$ & $<$ & $1.00 \mathrm{E}-02$ & \\
\hline 1 & ALPHA BHC & $<$ & $5.00 \mathrm{E}-01$ & $<$ & $1.00 \mathrm{E}-02$ & \\
\hline 1 & ANTHRACENE & $<$ & $2.00 \mathrm{E}+00$ & $<$ & $3.30 \mathrm{E}+00$ & \\
\hline 1 & DENZENE & $<$ & 8.00E-03 & $<$ & $5.00 \mathrm{E}-02$ & \\
\hline 1 & BENZIDINE & $<*$ & $1.00 \mathrm{E}+01$ & $<$ & $1.60 \mathrm{E}+01$ & \\
\hline 1 & BENZO(A)ANTHRACENE & $<$ & $2.00 \mathrm{E}+00$ & $<$ & $3.30 \mathrm{E}+00$ & \\
\hline 1 & BENZO(B)FLUORANTHENE & $<$ & $2.00 \mathrm{E}+00$ & $<$ & $3.30 \mathrm{E}+00$ & \\
\hline 1 & BENZO(GHI)PERYLENE & $<$ & $2.00 \mathrm{E}+00$ & $<$ & $3.30 \mathrm{E}+00$ & \\
\hline 1 & BENZO(K)FLUOR ANTHENE & $<$ & $2.00 \mathrm{E}+00$ & $<$ & $3.30 \mathrm{E}+00$ & \\
\hline 1 & BENZO-A-PYRENE & $<$ & $2.00 \mathrm{E}+00$ & $<$ & $3.30 \mathrm{E}+00$ & \\
\hline
\end{tabular}


Table B2 (continued)

\begin{tabular}{|c|c|c|c|c|c|}
\hline Roach & $\begin{array}{l}\text { Inorganic } \\
\text { Compound }\end{array}$ & & $\begin{array}{c}\text { Sodiment } \\
(\mathrm{mg} / \mathrm{kg}, \mathrm{dry})\end{array}$ & $\begin{array}{c}\text { Figh } \\
(\mathrm{mg} / \mathrm{kg} \text {, wot })\end{array}$ & $\begin{array}{l}\text { Wator } \\
(\mathrm{mg} / \mathrm{L})\end{array}$ \\
\hline 1 & BETA BHC & $<$ & $5.00 \mathrm{E}-01$ & $1,00 \mathrm{E}-02$ & \\
\hline 1 & BIS (2-CHLOROETHOXY) METHANE & $<$ & $2.00 \mathrm{E}+00$ & $3.30 \mathrm{E}+00$ & \\
\hline 1 & BIS (2-CHLOROETHYL) ETHER & $<$ & $2.00 \mathrm{E}+00$ & $3.30 \mathrm{E}+00$ & \\
\hline 1 & BIS (2-CHLOROISOPROPYL) ETHER & $<$ & $2.00 \mathrm{E}+00$ & $3.30 \mathrm{E}+00$ & \\
\hline 1 & BIS (2-ETHYLHEXYL) PHTHALATE & & $2.20 \mathrm{E}+00$ & $3.30 \mathrm{E}+00$ & \\
\hline 1 & BIS (CHLOROMETHYL) ETHER & $<$ & 8.00E-03 & 5.00E-02 & \\
\hline 1 & BROMOFORM & $<$ & $8.00 \mathrm{E}-03$ & $5.00 \mathrm{E} \cdot 02$ & \\
\hline 1 & CARBON TETRACHLORIDE & $<$ & 8.00E-03 & $5.00 \mathrm{E}-02$ & \\
\hline 1 & CHLORDANE & $<$ & $2.50 \mathrm{E}+00$ & $1.60 \mathrm{E}-01$ & \\
\hline 1 & CHLOROBENZENE & $<$ & 8.00E-03 & 5.00E-02 & \\
\hline 1 & CHLORODIBROMOMETHANE & $<$ & 8.00E-03 & 5.00E-02 & \\
\hline 1 & CHLOROETHANE & $<$ & $8.00 \mathrm{E}-03$ & $5.00 \mathrm{E}-02$ & \\
\hline 1 & CHLOROFORM & $<$ & 8.00E-03 & $5.00 \mathrm{E}-02$ & \\
\hline 1 & CHRYSENE & $<$ & $2.00 \mathrm{E}+00$ & $3.30 \mathrm{E}+00$ & \\
\hline 1 & DELTA BHC & $<$ & $5.00 \mathrm{E}-01$ & $1.00 \mathrm{E}-02$ & \\
\hline 1 & DI-N-BUTYL PHTHALATE & $<$ & $2.00 \mathrm{E}+00$ & $3.30 \mathrm{E}+00$ & \\
\hline 1 & DI-N-OCTYL PHTHALATE & $<$ & $2.00 \mathrm{E}+00$ & $3,30 \mathrm{E}+00$ & \\
\hline 1 & DICHLOROBROMOMETHANE & $<$ & 8.00E-03 & $5.00 \mathrm{E}-02$ & \\
\hline 1 & DICHLORODIFLUOROMETHANE & $<$ & 8.00E-03 & $5.00 \mathrm{E}-02$ & \\
\hline 1 & DIELDRIN & $<$ & 5.00E-01 & $1.00 \mathrm{E}-02$ & \\
\hline 1 & DIETHYL PHTHALATE & $<$ & $2.50 \mathrm{E}+00$ & $3.30 \mathrm{E}+00$ & \\
\hline 1 & DIMETHYL PHTHALATE & $<$ & $2.00 \mathrm{E}+00$ & $3.30 \mathrm{E}+00$ & \\
\hline 1 & ENDOSULFAN SULFATE & $<$ & $5.00 \mathrm{E}-01$ & $1.00 \mathrm{E}-02$ & \\
\hline 1 & ENDOSULFAN, ALPHA & $<$ & 5.00E-01 & $1.00 \mathrm{E}-02$ & \\
\hline 1 & ENDOSULFAN, BETA & $<$ & 5.00E-01 & $1.00 \mathrm{~L}-02$ & \\
\hline 1 & ENDRIN & $<$ & 5.00E-01 & $1.00 \mathrm{E}-02$ & \\
\hline 1 & ENDRIN ALDEHYDE & $<$ & $5.00 \mathrm{E}-01$ & $1.00 \mathrm{E}-02$ & \\
\hline 1 & ETHYLBENZENE & $<$ & $8.00 \mathrm{E}-03$ & $5.00 \mathrm{E}-02$ & \\
\hline 1 & FLUORANTHENE & & 5.90E-01 & $3.30 \mathrm{E}+00$ & \\
\hline 1 & FLUORENE & $<$ & $2.00 \mathrm{E}+00$ & $3.30 \mathrm{E}+00$ & \\
\hline 1 & GAMMA-BHC(LINDANE) & $<$ & $5.00 \mathrm{E}-01$ & $1.00 \mathrm{E}-02$ & \\
\hline 1 & HEPTACHLOR & $<$ & $5.00 \mathrm{E}-01$ & $1.00 \mathrm{E}-02$ & \\
\hline 1 & HEPTACHLOR EPOXIDE & $<$ & $5.00 \mathrm{E}-01$ & $1.00 \mathrm{E}-02$ & \\
\hline 1 & HEXACHLOROBENZENE & $<$ & $2.00 \mathrm{E}+00$ & $3.30 \mathrm{E}+00$ & \\
\hline 1 & HEXACHLOROBUTADIENE & $<$ & $2.00 \mathrm{E}+00$ & $3.30 \mathrm{E}+00$ & \\
\hline 1 & HEXACHLOROCYCLOPENTADIENE & $<$ & $2.00 \mathrm{E}+00$ & $3.30 \mathrm{E}+00$ & \\
\hline 1 & HEXACHLOROETHANE & $<$ & $2.00 \mathrm{E}+00$ & $3.30 \mathrm{E}+00$ & \\
\hline 1 & INDENO (1,2,3-CD) PYRENE & $<$ & $2.00 E+00$ & $3.30 \mathrm{E}+00$ & \\
\hline 1 & ISOPHORONE & $<$ & $2.00 \mathrm{E}+00$ & $3.30 \mathrm{E}+00$ & \\
\hline 1 & METHYL BROMTDE & $<$ & 8.00E-03 & 5.00E-02 & \\
\hline 1 & METHYL CHLORIDE & $<$ & 8.00E-03 & 5.00E-02 & \\
\hline 1 & METHYLENE CHLORIDE & & $1.00 \mathrm{E}-01$ & $2.50 \mathrm{E}-01$ & \\
\hline 1 & N-BUTYL BENZXI PHTHALATE & $<$ & $2.00 \mathrm{E}+00$ & $3.30 \mathrm{E}+00$ & \\
\hline 1 & N-NITROSODI-N-PROPYLAMINE & $<$ & $2.00 \mathrm{E}+00$ & $3.30 \mathrm{E}+00$ & \\
\hline 1 & N-NITROSODIMETHYLAMINE & $<$ & $2.00 \mathrm{E}+00$ & $3.30 E+00$ & \\
\hline
\end{tabular}


Table B2 (continued)

\begin{tabular}{|c|c|c|c|c|c|c|}
\hline Roach & $\begin{array}{l}\text { Inorganic } \\
\text { Compound }\end{array}$ & & $\begin{array}{c}\text { Sedimont } \\
\text { (mg/kg, dry) }\end{array}$ & & $\begin{array}{c}\text { Fish } \\
(\mathrm{mg} / \mathrm{kg} \text {, wot })\end{array}$ & $\begin{array}{l}\text { Wator } \\
(\mathrm{mg} / \mathrm{L})\end{array}$ \\
\hline 1 & N-NITROSODIPHENYLAMINE & $<$ & $2.00 \mathrm{E}+00$ & $<$ & $3.30 \mathrm{E}+00$ & \\
\hline 1 & NAPHTHALENE & $<$ & $2.00 \mathrm{E}+00$ & $<$ & $3.30 \mathrm{E}+00$ & \\
\hline 1 & NITROBENZENE & $<$ & $2.00 E+00$ & $<$ & $3.30 \mathrm{E}+00$ & \\
\hline 1 & P,P'DDD & $<$ & $5.00 \mathrm{E}-01$ & & $1.00 \mathrm{E}-01$ & \\
\hline 1 & P,P'DDE & $<$ & $5,00 \mathrm{E}-01$ & $<$ & $1.00 \mathrm{E}-02$ & \\
\hline 1 & P,P'DD'T & $<$ & $5.00 \mathrm{E}-01$ & & $1.60 \mathrm{E}-01$ & \\
\hline 1 & PARACHLOROMETA CRESOL & $<$ & $5.00 \mathrm{E}-01$ & $<$ & $3.30 \mathrm{E}+00$ & \\
\hline 1 & PCB-1254 (AROCLOR 1254) & $<$ & $5.00 \mathrm{E}+00$ & & $1.40 \mathrm{E}+00$ & \\
\hline 1 & PCB-1260 (AROCLOR 1260) & $<$ & $5.00 \mathrm{E}+00$ & & $3.40 \mathrm{E}+00$ & \\
\hline 1 & PEN'SACHLOROPHENOL & $<$ & $5.00 \mathrm{E}-01$ & $<$ & $3.30 \mathrm{E}+00$ & \\
\hline 1 & PHENANTHRENE & $<$ & $2.00 \mathrm{E}+00$ & $<$ & $3.30 \mathrm{E}+00$ & \\
\hline 1 & PHENOL & $<$ & $5.00 \mathrm{E}-01$ & $<$ & $3.30 \mathrm{E}+00$ & \\
\hline 1 & PYRENE & $<$ & $2.00 \mathrm{E}+00$ & $<$ & $3.30 \mathrm{E}+00$ & \\
\hline 1 & TETRACHIOROETHYLENE & & & $<$ & $5.00 \mathrm{E}-02$ & \\
\hline 1 & TOLUUENE & $<$ & $8.00 \mathrm{E}-03$ & $<$ & $5.00 \mathrm{E}-02$ & \\
\hline 1 & TOXAPHENE & $<$ & $5.00 \mathrm{E}+00$ & $<$ & $5.00 \mathrm{E}-01$ & \\
\hline 1 & TRANS-1,2-DICHLOROETHENE & $<$ & $8.00 \mathrm{E}-03$ & $<$ & $5.00 \mathrm{E}-02$ & \\
\hline 1 & TRICHLOROETHYLENE & & & $<$ & $5.00 \mathrm{E}-02$ & \\
\hline 1 & TRICHLOROFLUOROMETHANE & $<$ & $8.00 \mathrm{E}-03$ & $<$ & $5.00 \mathrm{E}-02$ & \\
\hline 1 & VINYL CHLORIDE & $<$ & $8.00 \mathrm{E}-03$ & $<$ & $5.00 \mathrm{E}-02$ & \\
\hline 2 & 1,1,1-TRICHLOROETHANE & & & $<$ & 5.00E-02 & \\
\hline 2 & 1,1,2,2-TETRACHLOROETHANE & & & $<$ & $5,00 \mathrm{E}-02$ & \\
\hline 2 & 1,1,2-TRICHLOROETHANE & & & $<$ & 5.00E-02 & \\
\hline 2 & 1,1-DICHLOROETHANE & & & $<$ & $5.00 \mathrm{E}-02$ & \\
\hline 2 & 1,1-DICHLOROETIYLENE & & & $<$ & 5.00E-02 & \\
\hline 2 & 1,2,4-TRICHLOROBENZENE & $<$ & $1.40 \mathrm{E}+00$ & $<$ & $6.70 \mathrm{E}-01$ & \\
\hline 2 & 1,2,5,6-DIBENZAANTHRACENE & $<$ & $1.40 \mathrm{E}+00$ & $<$ & $6.70 \mathrm{E}-01$ & \\
\hline 2 & 1,2-DICHLOROBENZENE & $<$ & $1.40 \mathrm{E}+00$ & $<$ & $6.70 \mathrm{E}-01$ & \\
\hline 2 & 1,2-DICHLOROETHANE & & & $<$ & $5.00 \mathrm{E}-02$ & \\
\hline 2 & 1,2-DICHLOROPROPANE & & & $<$ & $5.00 \mathrm{E}-02$ & \\
\hline 2 & 1,2-DIPHENYLHYDRAZINE & $<$ & $1.40 \mathrm{E}+00$ & $<$ & $6.70 \mathrm{E}-01$ & \\
\hline 2 & 1,3-DICHLOROBENZENE & $<$ & $1.40 \mathrm{E}+00$ & $<$ & $6.70 \mathrm{E}-01$ & \\
\hline 2 & 1,3-DICHI.OROPROPENE & & & $<$ & $5.00 \mathrm{E}-02$ & \\
\hline 2 & 1,4-DICHLOROBENZENE & $<$ & $1.40 \mathrm{E}+00$ & $<$ & 6.70E-01 & \\
\hline 2 & 2,4,6-TRICHLOROPHENOL & & & $<$ & $6.70 \mathrm{E}-01$ & \\
\hline 2 & 2,4-DICHLOROPHENOL & & & $<$ & $6.70 \mathrm{E}-01$ & \\
\hline 2 & 2,4-DIMETHYLPHENOL & & & $<$ & $6.70 \mathrm{E}-01$ & \\
\hline 2 & 2,4-DINITROPHENOL & & & $<$ & $6.70 \mathrm{E}+00$ & \\
\hline 2 & 2,4-DINITROTOLUENE & $<$ & $1.40 \mathrm{E}+00$ & $<$ & $6.70 \mathrm{E}-01$ & \\
\hline 2 & 2,6-DINITROTOLUENE & $<$ & $1.40 \mathrm{E}+00$ & $<$ & $6.70 \mathrm{E}-01$ & \\
\hline 2 & 2-CHLOROETHYL VINYL ETHER & & & $<$ & 5.00E-02 & \\
\hline 2 & 2-CHLORONAPHTHALENE & $<$ & $1.40 \mathrm{E}+00$ & $<$ & $6.70 \mathrm{E}-01$ & \\
\hline 2 & 2.CHLOROPHENOL & & & $<$ & $6.70 \mathrm{E}-01$ & \\
\hline 2 & 2-NITROPHENOL & & & $<$ & $6.70 \mathrm{E}-01$ & \\
\hline 2 & 3,3'-DICHLOROBENZIDINE & $<$ & $3.50 \mathrm{E}+00$ & $<$ & $1.70 \mathrm{E}+00$ & \\
\hline
\end{tabular}


Table B2 (continued)

\begin{tabular}{|c|c|c|c|c|c|c|c|}
\hline Reach & $\begin{array}{l}\text { Inorganic } \\
\text { Compound } \\
\end{array}$ & & $\begin{array}{c}\text { Sediment } \\
\text { (mg/kg, dry) }\end{array}$ & & $\begin{array}{c}\text { Fish } \\
(\mathrm{mg} / \mathrm{kg} \text {, wet }) \\
\end{array}$ & & $\begin{array}{l}\text { Wator } \\
(\mathrm{mg} / \mathrm{L})\end{array}$ \\
\hline 2 & 4-BROMOPHENYL PHENYL E'THER & $<$ & $1.40 \mathrm{E}+00$ & $<$ & $6.70 \mathrm{E}-01$ & & \\
\hline 2 & 4-CHLOROPHENYL PHENYL ETHER & $<$ & $1.40 \mathrm{E}+00$ & $<$ & $6.70 \mathrm{E}-01$ & & \\
\hline 2 & ACENAPHTHENE & $<$ & $1.40 \mathrm{E}+00$ & $<$ & $6.70 \mathrm{E}-01$ & & \\
\hline 2 & ACENAPHTHYLENE & $<$ & $1.40 \mathrm{E}+00$ & $<$ & $6.70 \mathrm{E}-01$ & & \\
\hline 2 & ACROLEIN & & & $<$ & 5.00E-02 & & \\
\hline 2 & ACRYLONITRILE & & & $<$ & $5.00 \mathrm{E}-02$ & & \\
\hline 2 & ALDRIN & & & r & $1.00 \mathrm{E}-02$ & & \\
\hline 2 & ALPHA BHC & & & $<$ & $1.00 \mathrm{E}-02$ & & \\
\hline 2 & ANTHRACENE & $<$ & $1.40 \mathrm{E}+00$ & $<$ & $6.70 \mathrm{E}-01$ & & \\
\hline 2 & BENZENE & & & $<$ & $5.00 \mathrm{E}-02$ & & \\
\hline 2 & BENZIDINE & <*** & $7.00 E+00$ & $<$ & $3.40 \mathrm{E}+00$ & & \\
\hline 2 & BENZO(A)ANTHRACENE & 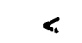 & $1.40 \mathrm{E}+00$ & $<$ & 6.70E-01 & & \\
\hline 2 & BENZO(B)FLUORANTHENE & $<$ & $1.40 \mathrm{E}+00$ & $<$ & 6.70E-01 & & \\
\hline 2 & BENZO(GHI)PERYLENE & $<$ & $1.40 \mathrm{E}+00$ & $<$ & $6.70 \mathrm{E}-01$ & & \\
\hline 2 & BENZO(KDFLUOR . LNTHENE & $<$ & $1.40 \mathrm{E}+00$ & $<$ & 6.70E-01 & & \\
\hline 2 & BENZO-A-PYRENE & $<$ & $1.40 \mathrm{E}+00$ & $<$ & 6.7UE-01 & & \\
\hline 2 & BETA BHC & & & $<$ & $1.00 \mathrm{E}-02$ & & \\
\hline 2 & BIS (2-CHLOROETHOXY) METHANE & $<$ & $1.40 \mathrm{E}+00$ & $<$ & 6.70E-01 & & \\
\hline 2 & BIS (2-CHLOROETHYL) ETHER & $<$ & $1.40 \mathrm{E}+00$ & $<$ & $6.70 \mathrm{E}-01$ & & \\
\hline 2 & BIS (2-CHILOROISOPROPYL) ETHER & $<$ & $1.40 \mathrm{E}+00$ & $<$ & $6.70 \mathrm{E}-01$ & & \\
\hline 2 & BIS (2-ETHYLHEXYL) PHTHALATE & & $1.90 \mathrm{E}+00$ & $<$ & $6.70 \mathrm{E}-01$ & & \\
\hline 2 & BIS (CHLOROMETHYL) ETHER & & & $<$ & 5.00E-02 & & \\
\hline 2 & BROMOFORM & & & $<$ & $5.00 \mathrm{E}-02$ & $<$ & $5.00 \mathrm{E}-03$ \\
\hline 2 & CARBON TETRACHLORIDE & & & $<$ & $5.00 \mathrm{E}-02$ & & \\
\hline 2 & CHLORDANE & & & & 2.50E-01 & & \\
\hline 2 & CHILOROBENZENE & & & $<$ & $5.00 \mathrm{E}-02$ & & \\
\hline 2 & CHLORODIBROMOMETHANE & & & $<$ & 5.00E-02 & & \\
\hline 2 & CHLOROETHANE & & & $<$ & $5.00 \mathrm{E}-02$ & & \\
\hline 2 & CHLOROFORM & & & $<$ & $5.00 \mathrm{E}-02$ & $<$ & $5.00 \mathrm{E}-03$ \\
\hline 2 & CHRYSENE & $<$ & $1.40 \mathrm{E}+00$ & $<$ & 6.70E-01 & & \\
\hline 2 & DELTA BHC & & & $<$ & $1.00 \mathrm{E}-02$ & & \\
\hline 2 & DI-N-BUTYL PHTHALATE & $<$ & $1.40 \mathrm{E}+00$ & $<$ & $6.70 \mathrm{E}-01$ & & \\
\hline 2 & DI-N-OCTYL PHTHALATE & $<$ & $1.40 \mathrm{E}+00$ & $<$ & $6.70 \mathrm{E}-01$ & & \\
\hline 2 & DICHLOROBROMOMETHANE & & & $<$ & $5.00 \mathrm{E}-02$ & & \\
\hline 2 & DICHLORODIFLUOROMETHANE & & & $<$ & $5.00 \mathrm{E} \sim 02$ & & \\
\hline 2 & DIELDRIN & & & $<$ & $1.00 \mathrm{E}-02$ & & \\
\hline 2 & DIETHYL PHTHALATE & $<$ & $1.40 \mathrm{E}+00$ & $<$ & $6.70 \mathrm{E}-01$ & & \\
\hline 2 & DIMETHYL PHTHALATE & $<$ & $1.40 \mathrm{E}+00$ & $<$ & $6.70 \mathrm{E}-01$ & & \\
\hline 2 & ENDOSULFAN SULFATE & & & $<$ & $1.00 \mathrm{E}-02$ & & \\
\hline 2 & ENDOSULFAN, ALPHA & & & $<$ & $1.00 \mathrm{E}-02$ & & \\
\hline 2 & ENDOSULFAN, BETA & & & $<$ & $1.00 \mathrm{E}-02$ & & \\
\hline 2 & ENDRIN & & & $<$ & $1.00 \mathrm{E}-02$ & & \\
\hline 2 & ENDRIN ALDEHYDE & & & $<$ & $1.00 \mathrm{E}-02$ & & \\
\hline 2 & ETHYLBENZENE & & & $<$ & 5.00E-02 & & \\
\hline
\end{tabular}


Table B2 (continued)

\begin{tabular}{|c|c|c|c|c|c|c|c|}
\hline Reach & $\begin{array}{l}\text { Inorganic } \\
\text { Compound }\end{array}$ & & $\begin{array}{c}\text { Sediment } \\
\text { (mg/kg, dry) }\end{array}$ & & $\begin{array}{c}\text { Filih } \\
\text { (mg/kg, wet) }\end{array}$ & & $\begin{array}{l}\text { Water } \\
(\mathrm{mg} / \mathrm{L})\end{array}$ \\
\hline 2 & FLUORANTHENE & $<$ & $1.40 \mathrm{E}+00$ & $<$ & $6.70 \mathrm{E}-01$ & & \\
\hline 2 & FLUOKENE & $<$ & $1.40 \mathrm{E}+00$ & $<$ & $6.70 \mathrm{E}-01$ & & \\
\hline 2 & GAMMA-BHC(LINDANE) & & & $<$ & $1.00 \mathrm{E}-02$ & & \\
\hline 2 & HEPTACHLOR & & & $<$ & $1.00 \mathrm{E}-02$ & & \\
\hline 2 & HEPTACHLOR EPOXIDE & & & $<$ & $1.00 \mathrm{E}-02$ & & \\
\hline 2 & HEXACHLOROBENZENE & $<$ & $1.40 \mathrm{E}+00$ & $<$ & $6.70 \mathrm{E}-01$ & & \\
\hline 2 & HEXACHLOROBUTADIENE & $<$ & $1.40 \mathrm{E}+00$ & $<$ & $6.70 E-01$ & & \\
\hline 2 & HEXACHLOROCYCLOPENTADIENE & $<$ & $1.40 \mathrm{E}+00$ & $<$ & $6.70 \mathrm{E}-01$ & & \\
\hline 2 & HEXACHLOROETHANE & $<$ & $1.40 \mathrm{E}+00$ & $<$ & $6.70 \mathrm{E}-01$ & & \\
\hline 2 & INDENO (1,2,3-CD) PYRENE & $<$ & $1.40 \mathrm{E}+00$ & $<$ & 6.70E-01 & & \\
\hline 2 & ISOPHORONE & $<$ & $1.40 \mathrm{E}+00$ & $<$ & 6.70E-01 & & \\
\hline 2 & METHYL BROMIDE & & & $<$ & 5.00E-02 & & \\
\hline 2 & METHYL CHLORIDE & & & $<$ & $5.00 \mathrm{E}-02$ & & \\
\hline 2 & METHYLENE CHLORIDE & & & $<$ & 2.50E-01 & & \\
\hline 2 & N-BU'IYL BENZYL PHTHALATE & $<$ & $1.40 \mathrm{E}+\infty 0$ & $<$ & $6.70 \mathrm{E}-01$ & & \\
\hline 2 & N-NITROSODI-N-PROPYLAMINE & $<$ & $1.40 \mathrm{E}+00$ & $<$ & $6.70 \mathrm{E}-01$ & & \\
\hline 2 & N-NITROSODIMETHYLAMINE & $<$ & $1.40 \mathrm{E}+00$ & $<$ & 6.70E-01 & & \\
\hline 2 & N-NITROSODIPHENYLAMINE & $<$ & $1.40 E+00$ & $<$ & 6.70E-01 & & \\
\hline 2 & NAPHTHALENE & $<$ & $1.40 \mathrm{E}+00$ & $<$ & $6.70 \mathrm{E}-01$ & & \\
\hline 2 & NITROBENZENE & $<$ & $1.40 \mathrm{E}+00$ & $<$ & $6.70 \mathrm{E}-01$ & & \\
\hline 2 & P,P'DDD & & & $<$ & $1.00 \mathrm{E}-02$ & & \\
\hline 2 & P,P'DDE & & & $<$ & $1.00 \mathrm{E}-02$ & & \\
\hline 2 & P,P'DDT & & & & $9.00 \mathrm{E}-02$ & & \\
\hline 2 & PARACHLOROME'TA CRESOL & & & $<$ & $6.70 \mathrm{E}-01$ & & \\
\hline 2 & PCB-1254 (AROCLOR 1254) & & $1.20 \mathrm{E}+00$ & & $2.00 \mathrm{E}+00$ & & \\
\hline 2 & PCB-1260 (AROCLOR 1260) & & $1.60 \mathrm{E}+00$ & & $3.60 \mathrm{E}+00$ & & \\
\hline 2 & PENTACHLOROPHENOL & & & $<$ & $6.70 \mathrm{E}-01$ & & \\
\hline 2 & PHENANTHRENE & $<$ & $1.40 E+00$ & $<$ & $6.70 \mathrm{E}-01$ & & \\
\hline 2 & PYRENE & $<$ & $1.40 E+00$ & $<$ & $6.70 E-01$ & & \\
\hline 2 & TETRACHLOROETHYLENE & & & $<$ & 5.00E-02 & & \\
\hline 2 & TOLUENE & & & $<$ & $5.00 \mathrm{E}-02$ & & \\
\hline 2 & TOXAPHENE & & & $<$ & 5.00E-01 & & \\
\hline 2 & TRANS-1,2-DICHLOROETHENE & & & $<$ & $5.00 \mathrm{E}-02$ & & \\
\hline 2 & TRICHLOROETHYLENE & & & $<$ & $5.00 \mathrm{E}-02$ & $<$ & $5.00 \mathrm{E}-03$ \\
\hline 2 & TRICHLOROFLUOROMETHANE & & & $<$ & $5.00 \mathrm{E}-02$ & & \\
\hline 2 & VINYL CHLORIDE & & & $<$ & $5.00 \mathrm{E}-02$ & & \\
\hline 3 & 1,1,1-TRICHLOROETHANE & & & $<$ & 5.00E-02 & & $9,00 \mathrm{E}-02$ \\
\hline 3 & 1,1,2,2-TETRACHLOROETHANE & & & $<$ & $5.00 \mathrm{E}-02$ & $<$ & $5.00 \mathrm{E}-03$ \\
\hline 3 & 1,1,2-TRICHLOROETHANE & & & $<$ & $5.00 \mathrm{E}-02$ & & \\
\hline 3 & 1,1-DICHLOROETHANE & & & $<$ & $5.00 \mathrm{E}-02$ & $<$ & $5.00 \mathrm{E}-03$ \\
\hline 3 & 1,1-DICHLOROETHYLENE & & & $<$ & $5.00 \mathrm{E}-02$ & $<$ & $5.00 \mathrm{E}-03$ \\
\hline 3 & 1,2,4-TRICHLOROBENZENE & $<$ & $1.70 \mathrm{E}+00$ & $<$ & $6.70 \mathrm{E}-01$ & $<$ & $8.00 \mathrm{E}-03$ \\
\hline 3 & 1,2,5,6-DIBENZAN'THRACENE & $<$ & $1.70 \mathrm{E}+00$ & $<$ & $6.70 \mathrm{E}-01$ & & \\
\hline 3 & 1,2-DICHLOROBENZENE & $<$ & $1.70 \mathrm{E}+\infty 0$ & $<$ & $6.70 \mathrm{E}-01$ & $<$ & $8.00 \mathrm{E}-03$ \\
\hline
\end{tabular}


Table B2 (continued)

\begin{tabular}{|c|c|c|c|c|c|c|c|}
\hline Reach & $\begin{array}{l}\text { Inorganic } \\
\text { Compound }\end{array}$ & & $\begin{array}{l}\text { Sedimont } \\
\text { (mg/kg, dry) }\end{array}$ & & $\begin{array}{c}\text { Fish } \\
(\mathrm{mg} / \mathrm{kg}, \text { wot })\end{array}$ & & $\begin{array}{l}\text { Water } \\
(\mathrm{mg} / \mathrm{L})\end{array}$ \\
\hline 3 & 1,2-DICHLOROETHANE & & & $<$ & $5.00 \mathrm{E}-02$ & $<$ & $5.00 \mathrm{E}-03$ \\
\hline 3 & 1,2-DICHLOROPROPANE & & & $<$ & $5.00 \mathrm{E}-02$ & $<$ & $5.00 \mathrm{E}-03$ \\
\hline 3 & 1,2-DIPHENYLHYDRAZINE & $<$ & $1.70 \mathrm{E}+00$ & $<$ & $6.70 \mathrm{E}-01$ & & \\
\hline $\mathbf{3}$ & 1,3-DICHLOROBENZENE & $<$ & $1.70 \mathrm{E}+00$ & $<$ & 6.70E-01 & $<$ & $8.00 \mathrm{E}-03$ \\
\hline 3 & 1,3-DICHLOROPROPENE & & & $<$ & $5.00 \mathrm{E}-02$ & & \\
\hline 3 & 1,4-DICHILOROBENZENE & $<$ & $1.70 \mathrm{E}+00$ & $<$ & $6.70 \mathrm{E}-01$ & $<$ & $8.00 \mathrm{E}-03$ \\
\hline $\mathbf{3}$ & 2,4,6-TRICHLOROPHENOL & & & $<$ & $6.70 \mathrm{E}-01$ & $<$ & $8.00 \mathrm{E}-03$ \\
\hline 3 & 2,4-DICHLOROPHENOL & & & $<$ & 6.70E-01 & $<$ & $8.00 \mathrm{E}-03$ \\
\hline 3 & 2,4-DIMETHYLPHENOL & & & $<$ & $6.70 \mathrm{E}-01$ & $<$ & $8.00 \mathrm{E}-03$ \\
\hline 3 & 2,4-DINITROPHENOL & & & $<$ & $6.70 \mathrm{E}+00$ & $<$ & $2.90 \mathrm{E}-02$ \\
\hline 3 & 2,4-DINITROTOLUENE & $<$ & $1.70 \mathrm{E}+00$ & $<$ & 6.70E-01 & $<$ & $8.00 \mathrm{E}-03$ \\
\hline 3 & 2,6-DINITROTOLUENE & $<$ & $1.70 E+00$ & $<$ & $6.70 \mathrm{E}-01$ & $<$ & $8.00 \mathrm{E}-03$ \\
\hline $\mathbf{3}$ & 2-CHLOROETHXL VINYL ETHER & & & $<$ & $5.00 \mathrm{E}-02$ & $<$ & $1.00 \mathrm{E}-02$ \\
\hline 3 & 2-CHLORONAPHTHALENE & $<$ & $1.70 \mathrm{E}+00$ & $<$ & $6.70 \mathrm{E}-01$ & $<$ & $8.00 \mathrm{E}-03$ \\
\hline $\mathbf{3}$ & 2-CHLOROPHENOL & & & $<$ & $6.70 \mathrm{E}-01$ & $<$ & $8.00 \mathrm{E}-03$ \\
\hline 3 & 2-NITROPHENOI & & & $<$ & $6.70 \mathrm{E}-01$ & $<$ & $8.00 \mathrm{E}-03$ \\
\hline 3 & 3,3'-DICHLOROBENZIDINE & $<$ & $4.00 \mathrm{E}+00$ & $<$ & $1.70 \mathrm{E}+00$ & $<$ & $1.70 \mathrm{E}-02$ \\
\hline 3 & 4,6-DINITRO-ORTHO-CRESOL & & & $<$ & $3.40 \mathrm{E}+00$ & $<$ & $2.90 \mathrm{E}-02$ \\
\hline 3 & 4-BROMOPHENYL PHENYL ETHER & $<$ & $1.70 \mathrm{E}+00$ & $<$ & 6.70E-01 & $<$ & \&.00E-03 \\
\hline 3 & 4-CHLOROPHENYL PHENYL ETHER & $<$ & $1.70 \mathrm{E}+00$ & $<$ & 6.70E-01 & $<$ & $2.50 \mathrm{E}-02$ \\
\hline 3 & 4-NITROPHENOL & & & $<$ & $6.70 \mathrm{E}-01$ & & $4.20 \mathrm{E}-02$ \\
\hline 3 & ACENAPHTHENE & $<$ & $1.70 \mathrm{E}+00$ & $<$ & 6.70E-01 & $<$ & $8.00 \mathrm{E}-03$ \\
\hline 3 & ACENAPHTHYLENE & $<$ & $1.70 \mathrm{E}+00$ & $<$ & $6.70 \mathrm{E}-01$ & $<$ & $8.00 \mathrm{E}-03$ \\
\hline $\mathbf{3}$ & ACROLEIN & & & $<$ & $5.00 \mathrm{E}-02$ & & \\
\hline 3 & ACRYLONITRILE & & & $<$ & $5.00 \mathrm{E}-02$ & & \\
\hline 3 & ALDRIN & & & $<$ & $1.00 \mathrm{E}-02$ & & \\
\hline 3 & ALPHA BHC & & & $<$ & $1.00 \mathrm{E}-02$ & & \\
\hline $\mathbf{3}$ & ANTHRACENE & & 5.00E-01 & $<$ & 6.70E-01 & $<$ & $8.00 \mathrm{E}-03$ \\
\hline 3 & BENZENE & & & $<$ & $5.00 \mathrm{E}-02$ & $<$ & $5.00 \mathrm{E}-03$ \\
\hline 3 & BENZIDINE & $<* *$ & $8.00 \mathrm{E}+00$ & $<$ & $3.40 \mathrm{E}+00$ & $<$ & $8.00 \mathrm{E}-03$ \\
\hline 3 & BENZO(A)ANTHRACENE & & $5.00 \mathrm{E}-01$ & $<$ & $6.70 \mathrm{E}-01$ & $<$ & $8.00 \mathrm{E}-03$ \\
\hline 3 & BENZO(B)FLUORANTHENE & $<$ & $1.70 \mathrm{E}+00$ & $<$ & $6.70 \mathrm{E}-01$ & $<$ & $8.00 \mathrm{E}-03$ \\
\hline 3 & BENZO(GHI)PERYLENE & $<$ & $1.70 \mathrm{E}+00$ & $<$ & $6.70 \mathrm{E}-01$ & $<$ & $8.00 \mathrm{E}-03$ \\
\hline 3 & BENZO(K)FLUOR ANTHENE & $<$ & $1.70 \mathrm{E}+00$ & $<$ & 6.70区-01 & $<$ & $8.00 \mathrm{E}-03$ \\
\hline 3 & BENZO-A-PYRENE & $<$ & $1.70 \mathrm{E}+00$ & $<$ & 6.70E-01 & $<$ & $8.00 \mathrm{E}-03$ \\
\hline 3 & BETA BHC & & & $<$ & $1.00 \mathrm{E}-02$ & & \\
\hline 3 & BIS (2-CHLOROETHOXY) METHANE & $<$ & $1.70 \mathrm{E}+00$ & $<$ & $6.70 \mathrm{E}-01$ & $<$ & $8,00 \mathrm{E}-03$ \\
\hline 3 & BIS (2-CHLOROETHYL) ETHER & $<$ & $1.70 \mathrm{E}+00$ & $<$ & $6.70 \mathrm{E}-01$ & $<$ & $8.00 \mathrm{E}-03$ \\
\hline 3 & BIS (2-CHLOROISOPROPYL) ETHER & $<$ & $1.70 \mathrm{E}+00$ & $<$ & 6.70E-01 & $<$ & $8.00 \mathrm{E}-03$ \\
\hline 3 & BIS (2-ETHYLHEXYL) PHTHALATE & & $9.67 E+01$ & $<$ & $6.70 \mathrm{E}-01$ & & $8.30 \mathrm{E}-02$ \\
\hline 3 & BIS (CHLOROMETHYL) ETHER & & & $<$ & $5.00 \mathrm{E}-02$ & & \\
\hline 3 & BROMOFORM & & & $<$ & 5.00E-02 & $<$ & $5.00 \mathrm{E}-03$ \\
\hline 3 & BUTXLBENZYLPHTHALATE & & & & & $<$ & $8.00 \mathrm{E}-03$ \\
\hline 3 & CARBON TETRACHLORIDE & & & $<$ & $5.00 \mathrm{E}-02$ & & $1.90 \mathrm{E}-02$ \\
\hline
\end{tabular}


Table B2 (continued)

\begin{tabular}{|c|c|c|c|c|c|c|c|}
\hline Reach & $\begin{array}{l}\text { Inorganio } \\
\text { Compound }\end{array}$ & & $\begin{array}{c}\text { Sodimont } \\
(\mathrm{mg} / \mathrm{kg}, \mathrm{dry})\end{array}$ & & $\begin{array}{c}\text { F/sh } \\
(\mathrm{mg} / \mathrm{kg}, \text { wot }) \\
\end{array}$ & & $\begin{array}{l}\text { Wator } \\
(\mathrm{mg} / \mathrm{L})\end{array}$ \\
\hline 3 & CHLORDANE & & & $<$ & $1.00 \mathrm{E}-01$ & & \\
\hline 3 & CHLOROBENZENE & & & $<$ & 6.00E-02 & $<$ & $5.00 \mathrm{E}-03$ \\
\hline 3 & CHLORODIBROMOMETHANE & & & $<$ & $5.00 \mathrm{E}-02$ & & \\
\hline 3 & CHLOROETHLANE & & & $<$ & $5.00 \mathrm{E}-02$ & $<$ & $1.00 \mathrm{E}-02$ \\
\hline 3 & CHLOROFORM & & & $<$ & $5.00 \mathrm{E}-02$ & & $5.10 \mathrm{E}-02$ \\
\hline 3 & CHRYSENE & & 7.00E-01 & $<$ & $6.70 \mathrm{E}-01$ & $<$ & $8.00 \mathrm{E}-03$ \\
\hline 3 & CIS-1 3-DICHLOROPROPENE & & & & & $<$ & 6.00E-03 \\
\hline 3 & DELTA BHC & & & $<$ & $1.00 \mathrm{E}-02$ & & \\
\hline 3 & DI-N-BUTYL PHTHALATE & & $3.00 \mathrm{E} \cdot 01$ & $<$ & 6.70E-01 & $<$ & 8.00E-03 \\
\hline 3 & DI-N-OCTYL PHTHALATE & $<$ & $1.70 \mathrm{E}+00$ & $<$ & $6.70 \mathrm{E}-01$ & $<$ & 9.00E-03 \\
\hline 3 & DIBENZ(A H)ANTHRACENE & & & & & $<$ & 8.00E-03 \\
\hline 9 & DICHIOROBROMOMETHANE & & & $<$ & 5.00E-02 & $<$ & $5.00 \mathrm{E}-03$ \\
\hline 3 & DICHLORODIFLUOROMETHANE & & & $<$ & 5.00E-02 & & $1.50 \mathrm{E}-01$ \\
\hline 3 & DIELDRIN & & & $<$ & $1.00 \mathrm{E}-02$ & & \\
\hline 3 & DIETHYL, PHTHALATE & $<$ & $1.70 \mathrm{E}+00$ & $<$ & $6.70 \mathrm{E}-01$ & $<$ & $8.00 \mathrm{E}-03$ \\
\hline 3 & DIMETHYL PHTHALATE & $<$ & $1.70 \mathrm{E}+00$ & $<$ & $6.70 \mathrm{E}-01$ & $<$ & $8.00 \mathrm{E}-03$ \\
\hline 3 & ENDOSULFAN SULFATE & & & $<$ & $1,00 \mathrm{E}-02$ & & \\
\hline 3 & ENDOSULFAN, ALPHA & & & $<$ & $1.00 \mathrm{E}-02$ & & \\
\hline 3 & ENDOSULFAN, BETA & & & $<$ & $1.00 \mathrm{E} \cdot 02$ & & \\
\hline 3 & ENDRIN & & & $<$ & $1.00 \mathrm{E} \cdot 02$ & & \\
\hline 3 & ENDRIN ALDEHYDE & & & $<$ & $1.00 \mathrm{E}-02$ & & \\
\hline 3 & ETHYLBENZENE & & & $<$ & $5.00 \mathrm{E}-02$ & $<$ & $5.00 \mathrm{E} \cdot 03$ \\
\hline 3 & FLUORANTHENE & & $3.80 \mathrm{E}+00$ & $<$ & $6.70 \mathrm{E}-01$ & $<$ & $8.00 \mathrm{E}-03$ \\
\hline 3 & FLUORENE & $<$ & $1.70 \mathrm{E}+00$ & $<$ & 6.70E-01 & $<$ & $8.00 \mathrm{E}-03$ \\
\hline 3 & GAMMA-BHC(LINL)ANE) & & & $<$ & $1.00 \mathrm{E}-02$ & & \\
\hline 3 & HEPTACHLOR & & & $<$ & $1.00 \mathrm{E}-02$ & & \\
\hline 3 & HEPTACHLOR EPOXIDE & & & $<$ & $1.00 \mathrm{E}-02$ & & \\
\hline 3 & HEXACHLOROBENZENE & $<$ & $1.70 \mathrm{E}+00$ & $<$ & $6.70 \mathrm{E}-01$ & $<$ & $8.00 \mathrm{E}-03$ \\
\hline 3 & HEXACHLOROBUTADIENE & $<$ & $1.70 \mathrm{E}+00$ & $<$ & 6.70E-01 & $<$ & $8.00 \mathrm{E}-0.3$ \\
\hline 3 & HEXACHLOROCYCLOPENTADIENE & $<$ & $1.70 \mathrm{E}+00$ & $<$ & $6.70 \mathrm{E}-01$ & $<$ & 8.00E-03 \\
\hline 3 & HEXACHLOROETHANE & $<$ & $1.70 \mathrm{E}+00$ & $<$ & $6.70 \mathrm{E}-01$ & $<$ & $8.00 \mathrm{E}-03$ \\
\hline 3 & INDENO (1,2,3-CD) PYRENE & $<$ & $1.70 \mathrm{E}+00$ & $<$ & 6.70E-01 & $<$ & $8.00 \mathrm{E}-03$ \\
\hline 3 & ISOPHORONE & $<$ & $1.70 \mathrm{E}+00$ & $<$ & $6.70 \mathrm{E}-01$ & $<$ & 8.00E-03 \\
\hline 3 & METHYL BROMIDE & & & $<$ & $5.00 \mathrm{E}-02$ & $<$ & $1.00 \mathrm{E}-02$ \\
\hline 3 & METHYL CHLORIDE & & & $<$ & 5.00E-02 & $<$ & $1.00 \mathrm{E}-02$ \\
\hline 3 & METHYLENE CHLORIDE & & & $<$ & 2.50E-01 & & $2.40 \mathrm{E}-01$ \\
\hline 3 & N-BUTYL BENZYL PHTHALATE & $<$ & $1.70 \mathrm{E}+00$ & $<$ & $6.70 \mathrm{E}-01$ & & \\
\hline 3 & N-NITROSODI-N-PROPYLAMINE & $<$ & $1.70 E+00$ & $<$ & $6.70 \mathrm{E}-01$ & $<$ & $8.00 \mathrm{E}-03$ \\
\hline 3 & N-NITROSODIMETHYLAMINE & $<$ & $1.70 \mathrm{E}+00$ & $<$ & $6.70 \mathrm{E}-01$ & $<$ & $8.00 \mathrm{E}-03$ \\
\hline 3 & N.NITROSODIPHENYLAMINE & $<$ & $1.70 \mathrm{E}+00$ & $<$ & 6.70E-01 & $<$ & $8.00 \mathrm{E}-03$ \\
\hline 3 & NAPHTHALENE & $<$ & $1.70 \mathrm{E}+00$ & $<$ & $6.70 \mathrm{E}-01$ & $<$ & $8.00 \mathrm{E}-03$ \\
\hline 3 & NITROBENZENE & $<$ & $1.70 \mathrm{E}+00$ & $<$ & 6.70E-01 & $<$ & $8.00 \mathrm{E}-03$ \\
\hline 3 & P,P'DDD & & & $<$ & $1.00 \mathrm{E}-02$ & & \\
\hline 3 & P,P'DDE & & & $<$ & $1.00 \mathrm{E} \cdot 02$ & & \\
\hline 3 & P,P'DDT & & & $<$ & $1.00 \mathrm{E}-02$ & & \\
\hline
\end{tabular}


Table B2 (continued)

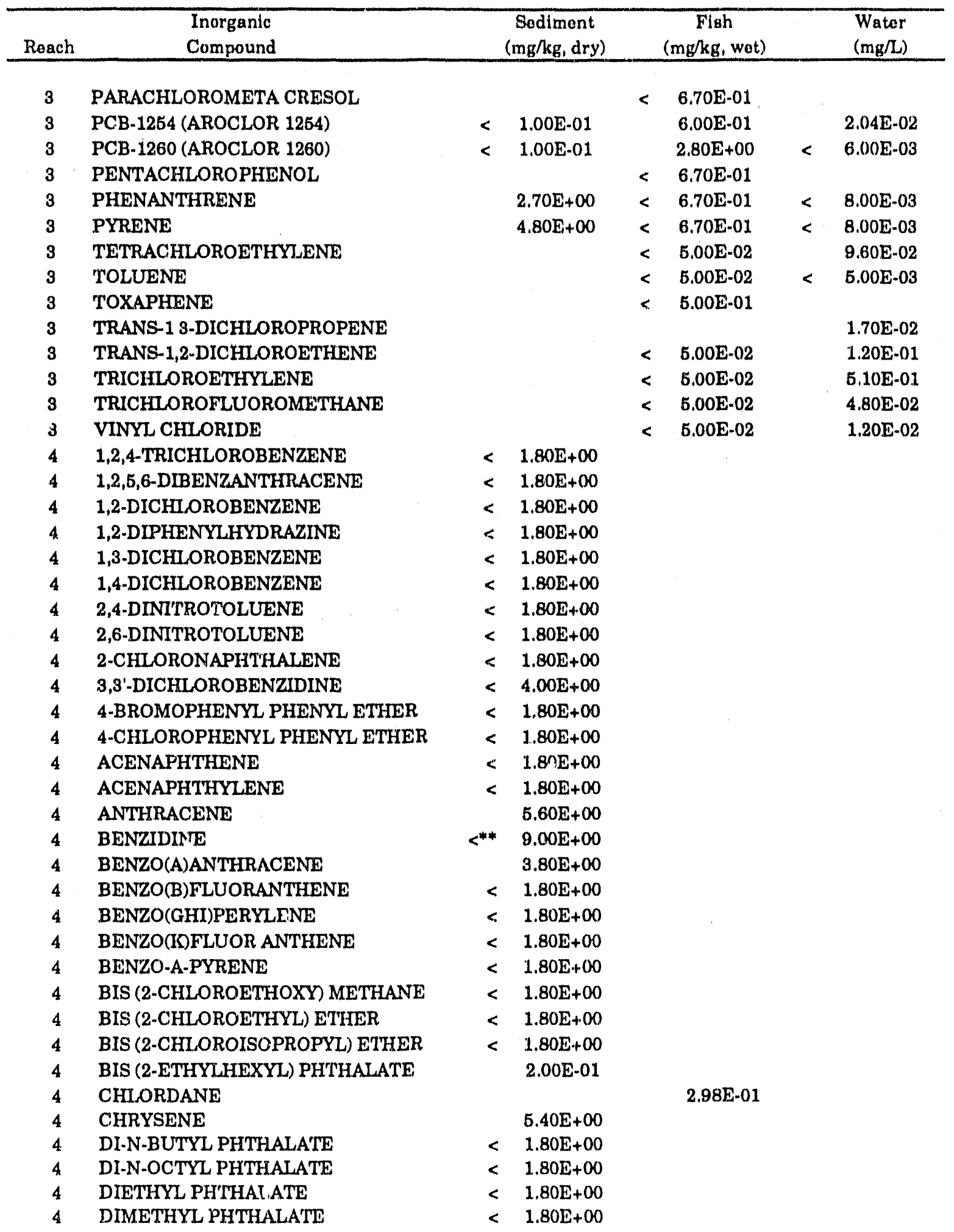


Table B2 (continued)

\begin{tabular}{|c|c|c|c|c|c|}
\hline Reach & $\begin{array}{c}\text { Inorganic } \\
\text { Compouild }\end{array}$ & & $\begin{array}{l}\text { Sodimont } \\
\text { (mg/kg, dry) }\end{array}$ & $\begin{array}{c}\text { Fish } \\
\left(\mathrm{mg} / \mathrm{kg}_{1} \text { wot }\right)\end{array}$ & $\begin{array}{l}\text { Wator } \\
(\mathrm{mg} / \mathrm{L})\end{array}$ \\
\hline 4 & FLUORANTHENE & $<$ & $1.80 \mathrm{E}+00$ & & \\
\hline 4 & FLUORENE & $<$ & $1.80 \mathrm{E}+00$ & & \\
\hline 4 & HEXACHLOROBENZENE & $<$ & $1.80 \mathrm{E}+00$ & & \\
\hline 4 & HEXACHLOROBUTADIENE & $<$ & $1.80 \mathrm{E}+00$ & & \\
\hline 4 & HEXACHLOROCYCLOPENTADIENE & $<$ & $1.80 \mathrm{E}+00$ & & \\
\hline 4 & HEXACHLOROETIIANE & $<$ & $1.80 \mathrm{E}+00$ & & \\
\hline 4 & INDENO (1,2,3-CD) PYRENE & $<$ & $1.80 \mathrm{E}+00$ & & \\
\hline 4 & ISOPHORONE & « & $1,80 \mathrm{E}+00$ & & \\
\hline 4 & N-BUTYL BENZYL PHTHALATE & $<$ & $1.80 \mathrm{E}+00$ & & \\
\hline 4 & N-NITROSODI-N-PR्OPXLAMINE & $<$ & $1.80 \mathrm{E}+10$ & & \\
\hline 4 & N-NITROSODIMETHYLAMINE & $<$ & $1.80 \mathrm{E}+00$ & & \\
\hline 4 & N-NITROSODIPHENYLAMINE & $<$ & $1.80 \mathrm{E}+00$ & & \\
\hline 4 & NAPHTHALENE & $<$ & $1.80 E+00$ & & \\
\hline 4 & NITROBENZENE & $<$ & $1,80 \mathrm{E}+00$ & & \\
\hline 4 & PCB.1254 (AROCLOR 1254) & $<$ & $1.00 \mathrm{E}-01$ & $1.10 \mathrm{E}+00$ & \\
\hline 4 & PCB-1260 (AROCLOR 1260) & $<$ & $1.00 \mathrm{E}-01$ & $1.20 \mathrm{E}+00$ & \\
\hline 4 & PHENANTHRFNE & & $5.40 \mathrm{E}+00$ & $4.60 \mathrm{E}+00$ & \\
\hline 4 & PYRENE & & $1.20 \mathrm{E}+01$ & & \\
\hline 5 & PCB-1254 (AROCLOR 1254) & $<$ & $1.00 \mathrm{E}-01$ & $1.70 \mathrm{E}+00$ & \\
\hline 5 & PCB.1260 (AROCLOR 1260) & $<$ & $1,00 \mathrm{E}-01$ & $3.40 \mathrm{E}+00$ & \\
\hline 10 & 1,2,4-TRICHLOROBENZENE & $<$ & $1.50 \mathrm{E}+00$ & & \\
\hline 10 & 1,2,5,6-DIBENZANTHRACENE & $<$ & $1.50 \mathrm{E}+00$ & & \\
\hline 10 & 1,2-DICHLOROBENZENE & $<$ & $1.50 \mathrm{E}+00$ & & \\
\hline 10 & 1,2-DIPHENYLHYDRAZINE & $<$ & $1.50 \mathrm{E}+00$ & & \\
\hline 10 & 1,3-DICHLOROBENZENE & $<$ & $1.50 \mathrm{E}+00$ & & \\
\hline 10 & 1,4-DICHLOROBENZENE & $<$ & $1.50 \mathrm{E}+00$ & & \\
\hline 10 & 2,4-DINITROTOLUENE & $<$ & $1.50 \mathrm{E}+00$ & & \\
\hline 10 & 2,6-DINITROTOLUENE & $<$ & $1.50 \mathrm{E}+\infty$ & & \\
\hline 10 & 2-CHLORONAPHTHALENE & $<$ & $1.50 \mathrm{E}+00$ & & \\
\hline 10 & 3,3'-DICHLOROBENZIDINE & $<$ & $3.80 \mathrm{E}+\infty 0$ & & \\
\hline 10 & 4-BROMOPHENYL PHENYL ETHER & $<$ & $1.50 \mathrm{E}+00$ & & \\
\hline 10 & 4-CHLOROPHENYL PHENYL ETHER & $<$ & $1.50 \mathrm{E}+00$ & & \\
\hline 10 & ACENAPHTHENE & $<$ & $1.50 \mathrm{E}+00$ & & \\
\hline 10 & ACENAPHTHYLENE & $<$ & $1.50 \mathrm{E}+00$ & & \\
\hline 10 & ANTHRACENE & $<$ & $1.60 \mathrm{E}+\infty 0$ & & \\
\hline 10 & BENZIDINE & $<$ & $7.50 \mathrm{E}+00$ & & \\
\hline 10 & BENZO(A)ANTHRACENE & $<$ & $1.50 \mathrm{E}+00$ & & \\
\hline 10 & BENZO(B)FLUORANTHENE & $<$ & $1.50 \mathrm{E}+00$ & & \\
\hline 10 & BENZO(GHI)PERYLENE & $<$ & $1.50 \mathrm{E}+00$ & & \\
\hline 10 & BENZO(K)FLUOR ANTHENE & $<$ & $1.50 \mathrm{E}+00$ & & \\
\hline 10 & BENZO-A-PYRENE & $<$ & $1.50 \mathrm{E}+00$ & & \\
\hline 10 & BIS (2-CHLOROETHOXY) METHANE & $<$ & $1.50 \mathrm{E}+00$ & & \\
\hline 10 & BIS (2-CHLOROETHYL) ETHER & $<$ & $1.50 \mathrm{E}+00$ & & \\
\hline 10 & BIS (2-CHLOROISOPROPYL) ETHER & $<$ & $1.50 \mathrm{E}+00$ & & \\
\hline 10 & BIS (2-ETHYLHEXXL) PHTHALATE & $<$ & $1.50 \mathrm{E}+00$ & & \\
\hline
\end{tabular}


Table 132 (continued)

\begin{tabular}{|c|c|c|c|c|}
\hline R.onoh & $\begin{array}{l}\text { Inorganlo } \\
\text { Compound }\end{array}$ & $\begin{array}{l}\text { Soddmont } \\
\left(m / k_{B} \text { dry) }\right.\end{array}$ & $\begin{array}{c}\text { Figh } \\
(m / y / k g, \text { wot })\end{array}$ & $\begin{array}{l}\text { Wator } \\
\text { (mp/L) }\end{array}$ \\
\hline 10 & CHRYSENE & $<1,50 \mathrm{E}+00$ & & \\
\hline 10 & DI-N-BUTYL PHTHAYAATT & $<1,50 \mathrm{E}+000$ & & \\
\hline 10 & DI-N.OCTYL PHTHAIAATE & $<1.60 \mathrm{E}+00$ & & \\
\hline 10 & DIETHYL PHTHALATE & $<\quad 1.50 \mathrm{E}+00$ & & \\
\hline 10 & DIME'THYL PHTHALAATE & $<1.500+00$ & & \\
\hline 10 & FLUORANTHENE & $<1,500+00$ & & \\
\hline 10 & FLUORENE & $<1,50 \mathrm{E}+00$ & & \\
\hline 10 & HEXACHLOROBENZENE & $<1,50 \mathrm{E}+00$ & & \\
\hline 10 & HEXACHLOROBUTACIENE & $<1.50 \mathrm{E}+\infty 0$ & & \\
\hline 10 & HEXACHLOROCYCLOPENTADIENE & $<1,500+00$ & & \\
\hline 10 & HEXACHLOROETIIANE & $<1.50 \mathrm{E}+00$ & & \\
\hline 10 & INDENO $(1,2,3-C D$, PYTIENE & $<1.60 \mathrm{E}+100$ & & \\
\hline 10 & ISOPHORONE & $<1.60 \mathrm{E}+00$ & & \\
\hline 10 & N-BUTYL BENZYL PH'THALATE & $<1,50 \mathrm{E}+00$ & & \\
\hline 10 & N-NITROSODI-N-PROPYI_AMINE & $<1.50 \mathrm{E}+00$ & & \\
\hline 10 & N-NITROSODIMETHYLAMINE & $1.50 \mathrm{E}+00$ & & \\
\hline 10 & N-NITROSODIPHENYLAMINE & $1.600+00$ & & \\
\hline 10 & NAPHTHALENE & $1.50 \mathrm{E}+00$ & & \\
\hline 10 & NITROBENZENE & $1.50 \mathrm{E}+\infty 0$ & & \\
\hline 10 & PCB-1254 (AROCLOR 1254) & $1.00 \mathrm{E}-01$ & & \\
\hline 10 & PCB-1260 (AROCLOR 1260) & $1.00 \mathrm{E}-01$ & & \\
\hline 10 & PHENANTHFENE & $<1.50 \mathrm{E}+00$ & & \\
\hline 10 & PYRENE & $1.50 \mathrm{E}+00$ & & \\
\hline 18 & PCB-1254 (AROCLOR 1254) & & $6.00 \mathrm{E}-01$ & \\
\hline 18 & PCB-1260 (AROCLOR 1260) & & $1,00 \mathrm{E}-01$ & \\
\hline
\end{tabular}

$<=$ bolow limits of dotoution.

$<^{* *}=$ dotectod as prosent, but not quantifiod. 
Table B3. Maximun concontrations of racilonuclidos

in sedimont, figh, and wator

\begin{tabular}{|c|c|c|c|c|c|c|c|}
\hline Ronch & Radionuolido & & $\begin{array}{l}\text { Sadimiont } \\
(\mathrm{Bq} / \mathrm{k} / \mathrm{g}, \mathrm{dry})\end{array}$ & & $\begin{array}{c}\text { Fluh } \\
\text { (Bc/kg, wat) }\end{array}$ & & $\begin{array}{l}\text { Wator } \\
(\mathrm{Bq} / \mathrm{L})\end{array}$ \\
\hline 1 & $00-60$ & & $7.77 \mathrm{E}+00$ & & 7.7015 .01 & $<$ & $9.215 \mathrm{I} .02$ \\
\hline 1 & $\mathrm{C}_{8 \times 137}$ & & $4.81 \mathrm{E}+01$ & & $8,1015+00$ & & $9.2 B 1-02$ \\
\hline 1 & $N p .237$ & $<$ & $8.00 \mathrm{~T}-01$ & & & & \\
\hline 1 & $P_{a-234}$ & & $1.48 \mathrm{E}+02$ & & & & \\
\hline 1 & Pu.238 & & $7.40 \mathbb{E}-02$ & & $2.60 \mathrm{E}-02$ & & \\
\hline 1 & Pu.239 & & B.65LL-01. & & $6.00 \mathrm{E} \cdot 03$ & & \\
\hline 1 & $\mathrm{Sr}-89$ & & $7.40 \mathrm{E}+00$ & & & & \\
\hline 1 & Sr-90 & & $3.70 \mathrm{E}+00$ & & $2.80 \mathrm{E}-01$ & & $1.41 \mathrm{E}-01$ \\
\hline 1 & $\operatorname{Tc} \cdot \theta \theta$ & $<$ & $2.81 E+01$ & & $1.48 \mathrm{E}+00$ & & \\
\hline 1 & Th-232 & & $2.50 \mathrm{E}+01$ & & & & \\
\hline 1 & U.234 & & $2.00 \mathrm{E}+01$ & & 1.93E-01 & & 5.18E-03 \\
\hline 1 & U-235 & & $7.77 \mathrm{E}+00$ & & $5.20 \mathrm{E} \cdot 02$ & & $1.86 \mathrm{E}-03$ \\
\hline 1 & U.236 & & & & & & $6.20 \mathrm{E} \cdot 00$ \\
\hline 1 & U.238 & & $1,30 \mathrm{E}+01$ & & $.1 .26 \mathrm{E}-01$ & & 3.33E-03 \\
\hline 2 & $A m-241$ & & $2.70 E+03$ & & & & $1.30 \mathrm{E}-01$ \\
\hline 2 & $\mathrm{Cm}-244$ & & $4.44 \mathrm{E}+02$ & & & & \\
\hline 2 & $\mathrm{Co}-60$ & & $1.62 E+04$ & & $3.40 \mathrm{E}+00$ & & $1.40 \mathrm{E}+00$ \\
\hline 2 & Cg-134 & & $6.29 \mathrm{E}+01$ & & & & \\
\hline 2 & C8-137 & & $1.74 \mathrm{E}+06$ & & $3.80 \mathrm{E}+02$ & & $1.10 \mathrm{E}+01$ \\
\hline 2 & $E u-162$ & & $3.20 E+02$ & & & & \\
\hline 2 & Eu-164 & & 5.18E+02 & & & & \\
\hline 2 & $\mathrm{H} \cdot 3$ & & & & & & $7.10 E+04$ \\
\hline 2 & Np.237 & & & & & 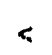 & $7.40 \mathrm{E} \cdot 02$ \\
\hline 2 & $\mathrm{~Pa}_{\mathrm{a}-234}$ & & $4.81 \mathrm{E}+0.1$ & & & & \\
\hline 2 & Pu-238 & & $1.52 \mathrm{E}+02$ & & 2.80E-02 & & $2.00 \mathrm{E}-01$ \\
\hline 2 & $P u-239$ & & $2.56 E+03$ & & $1.90 \mathrm{E}+00$ & & $2,80 \mathrm{E}-02$ \\
\hline 2 & Sr-89 & $<^{* *}$ & $6.33 E+03$ & $<^{* * *}$ & $1.18 \mathrm{E}+01$ & & \\
\hline 2 & Sr-90 & & $2.86 \mathrm{E}+04$ & & $1.54 \mathrm{E}+01$ & & $1,50 \mathrm{E}+01$ \\
\hline 2 & $\mathrm{Tc}-99$ & & & & & $<$ & $1.85 \mathrm{E}+01$ \\
\hline 2 & Th-234 & & $1.48 \mathrm{E}+02$ & & & & \\
\hline 2 & U.234 & & & & $1.87 \mathrm{E}-01$ & & $3.70 \mathrm{EM}=03$ \\
\hline 2 & U.235 & & $7.77 \mathrm{E}+01$ & & $1,60 \mathrm{E}-02$ & & $1.85 \mathrm{E} \cdot 93$ \\
\hline 2 & UI-236 & & & & & & $1.30 \mathrm{E}-05$ \\
\hline 2 & U.238 & & $9.07 \mathrm{E}+02$ & & $1.23 \mathrm{E}-01$ & & $2.52 \mathrm{E}-03$ \\
\hline 3 & $A m \div 241$ & & $1.22 \mathrm{E}+00$ & & & & \\
\hline 3 & $\mathrm{Cm}-244$ & & $2.96 \mathrm{E}-01$ & & & & \\
\hline 3 & $\mathrm{Co}-60$ & & $1.18 \mathrm{E}+03$ & & & & \\
\hline 3 & $\mathrm{C}_{4-134}$ & & $5.92 \mathrm{E}+00$ & & & & \\
\hline 3 & Cs-137 & & $2.33 E+02$ & & & $<$ & $3.70 \mathrm{E}+00$ \\
\hline 3 & $\mathrm{~Np}-237$ & & & & & $<$ & $7.40 \mathrm{E}-02$ \\
\hline
\end{tabular}


Table 33 (continuod)

\begin{tabular}{|c|c|c|c|c|c|}
\hline Roauh & Radionuolldo & $\begin{array}{l}\text { Sodlimont } \\
\text { (Bq/kg, dry) }\end{array}$ & $\begin{array}{c}\text { Fluh } \\
(\mathrm{B} / \mathrm{kg}, \mathrm{k}, \mathrm{t})\end{array}$ & & $\begin{array}{l}\text { Wator } \\
(\mathrm{Bq} / \mathrm{L})\end{array}$ \\
\hline 3 & Pa.233 & $1.11 \mathrm{II}+00$ & & & \\
\hline 3 & Pa.204 & $2.18(0)+02$ & & & \\
\hline 3 & $P u \cdot 238$ & $2.000 \mathrm{~K} .01$ & & & \\
\hline 3 & $P_{u}+239$ & $1.52 E+00$ & & & \\
\hline 3 & $8 r-80$ & $3.70 \mathbb{E}+00$ & & & \\
\hline 8 & $8 r+80$ & $7.20 \mathrm{E}+00$ & $5,28 \mathrm{E} \times 01$ & & \\
\hline 3 & To- $\theta 9$ & & $3.70 \mathrm{E}+00$ & $<$ & $1.85 \mathrm{E}+01$ \\
\hline 3 & $T h-234$ & $2.2211+02$ & & & \\
\hline 3 & U.235 & $2.78 \mathrm{E}+0.2$ & & & \\
\hline 3 & U.238 & $3.05 E+03$ & & & \\
\hline 4 & Am-241 & $1.96 \mathrm{E}+02$ & & & \\
\hline 4 & $\mathrm{Cm}-244$ & $3.39 \mathrm{E}+00$ & & & \\
\hline 4 & 00.60 & $2.92 E+02$ & $7.47 \mathrm{E} \cdot 01$ & $<$ & $9.26 \mathrm{E}-02$ \\
\hline 4 & $7,4 \cdot 137$ & $1.10 \sqrt{1}+04$ & $6.10 \mathrm{E}+01$ & $<$ & $9.26 \mathrm{E}-02$ \\
\hline 4 & i. 1.3 & & & & $5.56 \mathrm{E}+01$ \\
\hline 4 & $\mathrm{~Np} \cdot 237$ & & & $<$ & $7,40 \mathrm{Ii} \cdot 02$ \\
\hline 4 & $\mathrm{Pu} \cdot 238$ & $1.44 \pi \pm+01$ & 3.30ख-02 & & \\
\hline 4 & $\mathrm{Pu} 289$ & $1.80 \mathrm{E}+02$ & $3.30 \mathrm{E}-02$ & $<$ & 1.11E-01 \\
\hline 4 & $5 r-89$ & $7.40 \mathrm{E}+01$ & $7.40 \mathrm{E}-01$ & & \\
\hline 4 & Sr-90 & $4,33 E+02$ & $5.76 \mathrm{E}+00$ & & $1.59 \mathrm{E} \cdot 01$ \\
\hline 4 & $T$ Te- 89 & & $2,86 \mathrm{E}+00$ & $<$ & $1.85 \mathrm{E}+0.1$ \\
\hline 4 & Th.234 & $1.48 E+02$ & & & \\
\hline 4 & U.234 & & $1.08 \mathrm{E}+00$ & & $3.70 \mathrm{E} \cdot 03$ \\
\hline 4 & U-295 & $1.70 \mathbb{E}+02$ & $3.15 \mathrm{E}-01$ & & $1.90 \mathrm{E}-03$ \\
\hline 4 & U-236 & & & & $2.18 \mathrm{E}-05$ \\
\hline 4 & U-238 & $3.65 \mathrm{E}+03$ & $4.40 \mathrm{E} \cdot 01$ & & $2.26 \mathrm{E}-03$ \\
\hline 5 & $\mathrm{Co}-60$ & $1.48 \mathrm{E}+02$ & & & \\
\hline B & $\mathrm{C} 8-137$ & $5.16 \mathrm{E}+03$ & & & \\
\hline 5 & Pu-238 & 6.29E-01 & & & \\
\hline 5 & Pun238 & $1.18 \mathrm{E}+01$ & & & \\
\hline 8 & Sr-90 & $1,11 \mathrm{E}+02$ & & & \\
\hline 10 & Arn-241 & $4,81 \mathbb{E} 01$ & & & \\
\hline 10 & $\mathrm{Cm} \cdot 244$ & $1,85 \mathrm{E}-01$ & & & \\
\hline 10 & $\mathrm{C}_{8-137}$ & $3,33 \mathrm{E}+01$ & & & \\
\hline 10 & $8 r-89$ & $1.48 E+02$ & & & \\
\hline 10 & Sr-90 & $1,48 \mathrm{E}+01$ & & & \\
\hline 18 & $\mathrm{C}_{8-137}$ & $1.50 \mathrm{E}+01$ & & & \\
\hline
\end{tabular}

$<=$ lese than doteotion limit.

$<* *$ present, but bolow the detection limit. 
Table B4. Mean concentrations of inorganic chemicals in sediment, fish, and water

\begin{tabular}{|c|c|c|c|c|c|c|c|}
\hline Roach & $\begin{array}{l}\text { Inorganio } \\
\text { compound }\end{array}$ & $N$ & $\begin{array}{l}\text { Sediment } \\
\text { (mg/leg, dry) }\end{array}$ & $N$ & $\begin{array}{c}\text { Fish } \\
(\mathrm{mg} / \mathrm{kg} \text {, wot }) \\
\end{array}$ & $N$ & $\begin{array}{l}\text { Water } \\
(\mathrm{mg} / \mathrm{L}) \\
\end{array}$ \\
\hline 1 & ANTIMONY & 1 & $3.00 \mathrm{E}-01$ & 2 & $1.00 E+100$ & & \\
\hline 1 & ARSENIC & 2 & $1.45 \mathrm{E}+01$ & 35 & $8.43 \mathrm{E} \cdot 02$ & 118 & $2.06 \mathrm{E} \cdot 01$ \\
\hline 1 & BERYLLIUM & 2 & $1.60 \mathrm{E}+00$ & 13 & $2.92 \mathrm{E}-02$ & & \\
\hline 1 & CADMIUM & 1 & $5.00 \mathrm{E} \cdot 01$ & 67 & $1.33 \mathrm{E}-02$ & & \\
\hline 1 & CHROMIUM & 2 & $2.20 \mathrm{E}+01$ & 84 & $6.54 \mathrm{E}-02$ & 118 & $6.00 \mathrm{E} \cdot 03$ \\
\hline 1 & COPPER & 2 & $4.40 \mathrm{E}+01$ & 20 & $6.49 \mathrm{E}-01$ & 118 & $3.00 \mathrm{E}-03$ \\
\hline 1 & CXANIDE & 1 & 4.00E.01 & & & & \\
\hline 1 & LEAD & 2 & $4.86 E+01$ & 29 & $2.29 \mathrm{E}-01$ & & \\
\hline 1 & MERCURY & 2 & $1.05 \mathrm{E} \cdot 01$ & 87 & $8.79 \mathrm{E}-02$ & 110 & \\
\hline 1 & NICKEL & 2 & $2.33 E+01$ & 9 & $1.00 \mathrm{E}+00$ & 118 & $8.00 \mathrm{E} \cdot 03$ \\
\hline 1 & SELENIUM & 1 & $2.00 \mathrm{E}+00$ & 29 & $6.76 \mathrm{E} .01$ & 118 & $2.00 \mathrm{E}-02$ \\
\hline 1 & SILVER & & & 11 & 2.91E-01 & & \\
\hline 1 & THALLIUM & & & 4 & $2.20 \mathrm{E}+00$ & & \\
\hline 1 & URANIUM & 1 & $5,80 \mathrm{E}+00$ & & & & \\
\hline 1. & ZINO & 2 & $1.35 \mathrm{E}+02$ & 29 & $7.30 \mathrm{E}+00$ & 118 & $4.00 \mathrm{E}-03$ \\
\hline 1 & ZIRCONIUM & 1 & $2.30 \mathrm{E}+02$ & & & & \\
\hline 2 & ALUMINUM & 4 & $7.16 \mathrm{E}+03$ & & & 167 & $5.46 \mathrm{E}-01$ \\
\hline 2 & ANTIMONY & & & 1 & $1.00 \mathrm{E}+00$ & & \\
\hline 2 & ARSENIC & 5 & $8.86 \mathrm{E}+00$ & 25 & $2.26 \mathrm{E}-01$ & 81 & $2.03 \mathrm{E}-02$ \\
\hline 2 & BERYLLIUM & & & 4 & 2.50E-02 & 10 & $9.20 \mathrm{E}-04$ \\
\hline 2 & CADMIUM & 6 & $1.66 \mathrm{E}+00$ & 17 & $7.24 \mathrm{E}-03$ & 40 & 2.23E-03 \\
\hline 2 & CHROMIUM & 11 & $5.18 \mathrm{E}+01$ & 17 & $9.00 \mathrm{E}-02$ & 54 & $1.50 \mathrm{E}-02$ \\
\hline 2 & COPPER & 6 & $1.27 \mathrm{E}+01$ & 11 & $1.63 \mathrm{E}+00$ & 91 & $2,06 \mathrm{E}-02$ \\
\hline 2 & CYANIDE & & & & & 24 & 5.50E-03 \\
\hline 2 & LEAD & 11 & $2.57 \mathrm{E}+01$ & 10 & $1.72 \mathrm{E}-01$ & 91 & $8.08 \mathrm{E}-03$ \\
\hline 2 & MERCURY & 7 & $1.86 \mathrm{E}+00$ & 77 & $8.36 \mathrm{E}-02$ & 71 & $1.50 \mathrm{E}-04$ \\
\hline 2 & NICKEEL & 11 & $1.81 \mathrm{E}+01$ & 1 & $1.00 \mathrm{E}+00$ & 82 & 2.81E-02 \\
\hline 2 & SELENIUM & 2 & $7.45 E+01$ & 11 & 2.61E-01 & & \\
\hline 2 & SILVER & 4 & $4.20 E+00$ & 4 & $3.75 \mathrm{E}-01$ & 10 & $1.00 \mathrm{E}-03$ \\
\hline 2 & THALLIUM & & & 1 & $1.00 \mathrm{E}+00$ & & \\
\hline 2 & URANIUM & 10 & $2.22 \mathrm{E}+00$ & & & & \\
\hline 2 & ZINC & 6 & $5.25 \mathrm{E}+01$ & 12 & $7.33 \mathrm{E}+00$ & 90 & $3.20 \mathrm{E}-02$ \\
\hline 2 & ZIRCONIUM & 5 & $5.13 \mathrm{E}+02$ & & & & \\
\hline 3 & ALUMחNUM & 24 & $2.08 \mathrm{E}+04$ & & & 444 & $3.59 \mathrm{E}-01$ \\
\hline 3 & ANTIMONY & & & 2 & $1.00 \mathrm{E}+00$ & 219 & $5,20 \mathrm{E} \cdot 02$ \\
\hline 3 & ARSENIC & 7 & $2.32 \mathrm{E}+01$ & 30 & $2.20 \mathrm{E}-01$ & 195 & $8.40 \mathrm{E}-03$ \\
\hline 3 & BARIUM & & & & & & \\
\hline 3 & BERYLLIUM & & & 4 & 2,50E-02 & 510 & $1.00 \mathrm{E}-03$ \\
\hline 3 & BORON & & & & & 226 & $1.94 \mathrm{E}-01$ \\
\hline 9 & CADMIUM & 17 & $1.86 E+00$ & 28 & $9.93 \mathrm{E}-03$ & 655 & $2.89 \mathrm{E}-03$ \\
\hline
\end{tabular}


Table B4 (continued)

\begin{tabular}{|c|c|c|c|c|c|c|c|}
\hline Reach & $\begin{array}{l}\text { Inorganic } \\
\text { compound }\end{array}$ & $N$ & $\begin{array}{c}\text { Sediment } \\
(\mathrm{mg} / \mathrm{kg}, \mathrm{dry})\end{array}$ & $N$ & $\begin{array}{c}\text { Fish } \\
\left(\mathrm{mg} / \mathrm{kg}_{\text {。 }} \text { wet }\right)\end{array}$ & $N$ & $\begin{array}{l}\text { Water } \\
(\mathrm{mg} / \mathrm{L})\end{array}$ \\
\hline 3 & CHROMIUM & 46 & $4.58 \mathrm{E}+01$ & 30 & $1.62 \mathrm{E}-01$ & 640 & $1.18 \mathrm{E}-02$ \\
\hline 3 & COPPER & 43 & $5.47 E+01$ & 14 & $7.84 \mathrm{E}-01$ & 363 & $9.96 \mathrm{E}-03$ \\
\hline 3 & CYANIDE & & & & & 195 & $1.76 \mathrm{E}-02$ \\
\hline 3 & LEAD & 46 & $3.18 \mathrm{E}+01$ & 14 & $8.86 \mathrm{E}-02$ & 664 & $1.23 E-02$ \\
\hline 3 & MERCURY & 45 & $1.10 \mathrm{E}+01$ & 40 & 4.90E-01 & 543 & 8.84E-06 \\
\hline 3 & MOLYBDENUM & & & & & 226 & $1.10 \mathrm{E}-02$ \\
\hline 3 & NICKEL & 46 & $1.23 E+02$ & 2 & $1.50 \mathrm{E}+00$ & 359 & $9.59 \mathrm{E} \cdot 02$ \\
\hline 3 & NIOBIUM & & & & & 122 & $8.00 \mathrm{E}-03$ \\
\hline 3 & SELENIUM & 15 & $8.71 E+01$ & 15 & 2.79E-01 & & \\
\hline 3 & SILVER & 15 & $5.22 E+00$ & 2 & 4.00E-.01 & 514 & $1.00 \mathrm{E}-02$ \\
\hline 3 & THALLIUM & & & 3 & $1.00 \mathrm{E}+00$ & & \\
\hline 3 & TIN & & & & & 110 & $1.09 \mathrm{E}-02$ \\
\hline 3 & TITANIUM & & & & & 226 & $5.68 \mathrm{E}-03$ \\
\hline 3 & URANIUMI & 28 & $1.68 F+01$ & & & 190 & 2.37E-01 \\
\hline 3 & ZINC & 43 & $1.39 \mathrm{E}+02$ & 15 & $7.95 \mathrm{E}+00$ & 595 & $3.6 \div E-02$ \\
\hline 3 & ZIRCONIUIM & 3 & $3.43 \mathrm{E}+02$ & & & 122 & 4.70E-03 \\
\hline 4 & ALUMINUM & 5 & $1.79 \mathrm{E}+04$ & & & & \\
\hline 4 & ANTIMONY & & & & & & \\
\hline 4 & ARSENIC & 2 & $8.05 \mathrm{E}+00$ & 28 & $1.79 \mathrm{E}-01$ & 48 & $5.00 \mathrm{E} \cdot 03$ \\
\hline 4 & BARIUM & 1 & $4.36 \mathrm{E}+02$ & & & & \\
\hline 4 & BERYLLIUM & 1 & $2.41 \mathrm{E}+00$ & & & & \\
\hline 4 & BORON & 1 & $1.41 \mathrm{E}+02$ & & & & \\
\hline 4 & CADMIUM & 3 & $9.50 \mathrm{E}-01$ & 39 & $8.59 \mathrm{E}-03$ & 48 & $2.00 \mathrm{E}-03$ \\
\hline 4 & CHROMIUM & 9 & $1.68 \mathrm{E}+01$ & 38 & $1.11 \mathrm{E}-01$ & & \\
\hline 4 & COPPER & 6 & $1.80 \mathrm{E}+01$ & 2 & $4.80 \mathrm{E}-01$ & 145 & $1.59 \mathrm{E}-02$ \\
\hline 4 & CYANIDE & & & & & 48 & $4.25 \mathrm{E}-03$ \\
\hline 4 & LEAD & 9 & $1.57 \mathrm{E}+01$ & 4 & $1.90 \mathrm{E}-01$ & 48 & $4.97 \mathrm{E}-03$ \\
\hline 4 & MERCURY & 10 & $2.96 \mathrm{E}+00$ & 115 & $1.88 \mathrm{E}-01$ & 24 & $2.00 \mathrm{E}-04$ \\
\hline 4 & NICKEL & 9 & $1.85 E+01$ & 1 & $1.00 \mathrm{E}+00$ & 48 & $5.05 \mathrm{E}-02$ \\
\hline 4 & SELENIUM & 2 & $1.12 \mathrm{E}+02$ & 4 & $1.35 \mathrm{E}+00$ & & \\
\hline 4 & SILVER & 2 & $2.55 \mathrm{E}+00$ & & & & \\
\hline 4 & TITANIUM & 1 & $3.91 \mathrm{E}+03$ & & & & \\
\hline 4 & URANIUM & 6 & $2.67 \mathrm{E}+00$ & & & 33 & $2.36 \mathrm{E}-03$ \\
\hline 4 & VANADIUM & 1 & $9.21 E+01$ & & & & \\
\hline 4 & ZINC & 7 & $5.37 \mathrm{E}+01$ & 4 & $1.04 \mathrm{E}+01$ & 48 & $3.08 \mathrm{E}-02$ \\
\hline 4 & ZIRCONIUM & 3 & $3.73 \mathrm{E}+02$ & & & & \\
\hline 5 & ALUMINUM & & . & & & 4 & 1.70E-01 \\
\hline 5 & ARSENIC & 1 & $1.60 \mathrm{E}+01$ & 4 & $2.00 \mathrm{E}-01$ & & \\
\hline 5 & BERYLLIUM & 1 & $1.60 \mathrm{E}+00$ & & & & \\
\hline 5 & CADMIUM & & & 10 & $1.50 \mathrm{E}-02$ & & \\
\hline 5 & CHROMIUM & 4 & $3.61 \mathrm{E}+01$ & 8 & $2.30 \mathrm{E}-01$ & & \\
\hline
\end{tabular}


Table B4 (continued)

\begin{tabular}{|c|c|c|c|c|c|c|c|}
\hline I ach & $\begin{array}{l}\text { Inorganic } \\
\text { compound }\end{array}$ & $N$ & $\begin{array}{c}\text { Sediment } \\
(\mathrm{mg} / \mathrm{kg}, \mathrm{dry}\rangle\end{array}$ & $N$ & $\begin{array}{c}\text { Figh } \\
(\mathrm{mg} / \mathrm{kg} \text {. wet })\end{array}$ & $N$ & $\begin{array}{l}\text { Water } \\
\text { (ing/L) }\end{array}$ \\
\hline 5 & COPPER & 1 & $4.00 \mathrm{E}+01$ & & & & \\
\hline 5 & LEAD & 1 & $5.30 E+01$ & & & & \\
\hline 5 & MERCURY & 15 & $7.01 \mathrm{E} .01$ & 7 & $1.34 \mathrm{E} .01$ & & \\
\hline 5 & NICKEL & 1 & $2.40 E+01$ & & & & \\
\hline 5 & SELENIUM & 1 & $8.00 \mathrm{E}-01$ & & & & \\
\hline 5 & SILVER & & & & & & \\
\hline 5 & ZnNC & 1 & $2.20 E+02$ & & & & \\
\hline 10 & ARSENIC & 2 & $2.00 E+01$ & & & & \\
\hline 10 & CADMIUM & & & & & & \\
\hline 10 & CHROMIUM & 2 & $2.20 \mathrm{E}+01$ & & & & \\
\hline 10 & CYANIDE & & & & & & \\
\hline 10 & LEAD & 2 & $6.25 E+01$ & & & & \\
\hline 10 & MERCURY & 2 & $1.00 \mathrm{E}-01$ & & & & \\
\hline 10 & NICKEL & 2 & $2.55 E+01$ & & & & \\
\hline 10 & SILVER & & & & & & \\
\hline 10 & URANIUM & 2 & $4.25 E+00$ & & & & \\
\hline 10 & ZIRCONIUM & 2 & $1.95 E+02$ & & & & \\
\hline 13 & ARSENIC & & & & & 24 & $5.50 \mathrm{E}-03$ \\
\hline 13 & COPPER & & & & & 24 & $3.00 \mathrm{E}-03$ \\
\hline 13 & CYANIDE & & & & & 24 & 5.50E-03 \\
\hline 13 & LEAD & & & & & 24 & $6.00 \mathrm{E}-03$ \\
\hline 13 & NICKEL & & & & & 24 & $5.00 \mathrm{E}-02$ \\
\hline 13 & URANIUM & & & & & 23 & 5. $70 \mathrm{E}-03$ \\
\hline 13 & ZINC & & & & & 24 & 2.65E-02 \\
\hline 18 & ARSENIC & & & 3 & $2.00 \mathrm{E}-01$ & & \\
\hline 18 & CADMIUM & & & 14 & $6.21 E_{-03}$ & & \\
\hline 18 & CHROMIUM & & & 13 & 2.15E-01 & & \\
\hline 18 & MERCURY & & & 11 & $2.14 \mathrm{E}-01$ & & \\
\hline
\end{tabular}

$N=$ Number of observations that make up the mean value. 
Table B5. Mean coricentrations of organic chemicals in sediment, fish, and water

\begin{tabular}{|c|c|c|c|c|c|c|c|}
\hline Reach & $\begin{array}{c}\text { Organic } \\
\text { compound }\end{array}$ & $N$ & $\begin{array}{c}\text { Sodiment } \\
(\mathrm{mg} / \mathrm{kg}, \mathrm{dry})\end{array}$ & $N$ & $\begin{array}{c}\text { Fish } \\
(\mathrm{mg} / \mathrm{kg}, \text { wet })\end{array}$ & $N$ & $\begin{array}{l}\text { Water } \\
(\mathrm{mg} / \mathrm{L}) \\
\end{array}$ \\
\hline 1 & BIS (2-ETHYLHEXYL) PHTHALATE & 1 & $2.20 \mathrm{E}+00$ & & & & \\
\hline 1 & CHLORDANE & & & 2 & $1.60 \mathrm{E}-01$ & & \\
\hline 1 & FLUORANTTHENE & 1 & $5.90 \mathrm{E}-01$ & & & & \\
\hline 1 & METHYLENE CHLORIDE & 1 & $1.00 \mathrm{E}-01$ & & & & \\
\hline 1 & P,P'DDD & & & 1 & $1.00 \mathrm{E}-01$ & & \\
\hline 1 & PCB-1254 (AROCLOR 1254) & & & 60 & $1.38 \mathrm{E}-01$ & & \\
\hline 1 & PCB-1260 (AROCLOR 1260) & & & 61 & $2.56 \mathrm{E}-01$ & & \\
\hline 2 & BIS (2-ETHYLHEXYL) PHTHALATE & 2 & $1.75 \mathrm{E}+00$ & & & & \\
\hline 2 & CHLORDANE & & & 1 & $2.50 \mathrm{E}-01$ & & \\
\hline 2 & P,PDDT & & & 1 & $9.00 \mathrm{E}-02$ & & \\
\hline 2 & PCB-1254 (AROCLOR 1254) & 1 & $1.20 \mathrm{E}+00$ & 97 & 3.78E-01 & & \\
\hline 2 & PCB-1260 (AROCLOR 1260) & 1 & $1.60 \mathrm{E}+00$ & 97 & $6.38 \mathrm{E}-01$ & & \\
\hline 3 & 1,1,1-TRICKILOROETHANE & & & & & 1146 & $5.11 \mathrm{E}-03$ \\
\hline 3 & 4-NITROPHENOL & & & & & 13 & $2.62 E-02$ \\
\hline 3 & ANTHRACENE & 8 & 2.40E-01 & & & & \\
\hline 3 & BENZO(A)ANTHRACENE & 1 & $5.0 \cup \mathrm{-}-01$ & & & & \\
\hline 3 & BIS (2-ETHYLHEXYL) PHTHALATE & 12 & $9.05 E+00$ & & & 11 & $6.70 \mathrm{E}-03$ \\
\hline 3 & CARBON TETRACHLORIDE & & & & & 301 & $5.16 \mathrm{E}-03$ \\
\hline 3 & CHRYSENE & s. & $7.00 \mathrm{E}-01$ & & & & \\
\hline 3 & DI-N-BUTXL PHTHALATE & 7 & $1.30 \mathrm{E}-01$ & & & & \\
\hline 3 & DICHLORODIFLUOROMETHANE & & & & & 11 & $1.08 \mathrm{E}-02$ \\
\hline 3 & FLUORANTHENE & 11 & $6.70 \mathrm{E}-01$ & & & & \\
\hline 3 & METHYLENE CHLORIDE & & & & & 845 & $5.31 \mathrm{E}-03$ \\
\hline 3 & PCB-1254 (AROCLOR 1254) & & & 5 & 4.20E-01 & 136 & $1.42 \mathrm{E}-03$ \\
\hline 3 & PCB-1260 (AROCLOR 1260) & & & 6 & $1.43 E+00$ & & \\
\hline 3 & PHIENANTHRENE & 12 & $5.80 \mathrm{E}-01$ & & & & \\
\hline 3 & PYRENE & 10 & $7.20 \mathrm{E}-01$ & & & & \\
\hline 3 & TETRACHLOROETHYLENE & & & & & 845 & $5.07 \mathrm{E}-03$ \\
\hline 3 & TRICHLOROETHYLENE & & & & & 810 & $2.50 \mathrm{E}-02$ \\
\hline 3 & TRICHLOROFLUOROMETHANE & & & & & 52 & 4.70E-03 \\
\hline 3 & VINYL CHLORIDE & & & & & 301 & $6.02 \mathrm{E}-03$ \\
\hline 4 & CHLORDANE & & & 5 & $2.98 \mathrm{E}-01$ & & \\
\hline 4 & PCB-1254 (AROCLOR 1254) & & & 72 & $3.64 \mathrm{E}-01$ & & \\
\hline 4 & PCB-1260 (AROCLOR 1260) & & & 54 & $3.57 \mathrm{E}-01$ & & \\
\hline 5 & PCB-1254 (AROCLOR 1254) & & & 37 & 6.27E-01 & & \\
\hline 5 & PCB-1260 (AROCLOR 1260) & & & 33 & 8.79E-01 & & \\
\hline 18 & PCB-1254 (AROCLOR 1254) & & & 7 & $3.29 \mathrm{E}-01$ & & \\
\hline 18 & PCB-1260 (AROCLOR 1260) & & & 10 & $1.00 \mathrm{E}-01$ & & \\
\hline
\end{tabular}

$N=$ Number of observations that make up the mean value. 
Table B6. Mean concentrations of radionuclides in sediment, fish, and water

\begin{tabular}{|c|c|c|c|c|c|c|c|}
\hline Reach & Radionuclide & $N$ & $\begin{array}{c}\text { Sediment } \\
(\mathrm{Bq} / \mathrm{kg}, \mathrm{dry})\end{array}$ & $N$ & $\begin{array}{c}\text { Fish } \\
(\mathrm{Bq} / \mathrm{kg}, \text { wet })\end{array}$ & $N$ & $\begin{array}{l}\text { Wator } \\
(\mathrm{Bq} / \mathrm{L})\end{array}$ \\
\hline 1 & Co-60 & 1 & $7.77 \mathrm{E}+00$ & 25 & $2.10 \mathrm{E}-01$ & & \\
\hline 1 & Cs-137 & 2 & $3.61 \mathrm{E}+01$ & 29 & $1.14 \mathrm{E}+00$ & 4 & $9.25 \mathrm{E}-02$ \\
\hline 1 & $\mathrm{~Pa}-234$ & 2 & $7.96 \mathrm{E}+01$ & & & & \\
\hline 1 & Pu-238 & 1 & $7.40 \mathrm{E}-02$ & 13 & $4.00 \mathrm{E}-03$ & & \\
\hline 1 & Pu-239 & 1 & $5.55 \mathrm{E}-01$ & 13 & $2.00 \mathrm{E}-03$ & & \\
\hline 1 & Sr-89 & 1 & $7.40 \mathrm{E}+00$ & & & & \\
\hline 1 & Sr-90 & 2 & $2.90 \mathrm{E}+00$ & 47 & $1.64 \mathrm{E}-01$ & 4 & $9.25 \mathrm{E}-02$ \\
\hline 1 & Tc-99 & & & 4 & 8.88E-01 & & \\
\hline 1 & Th-232 & 1 & $2.59 \mathrm{E}+01$ & & 1 & & \\
\hline 1 & U-234 & 1 & $2.00 \mathrm{E}+01$ & 8 & $6.40 \mathrm{E}-02$ & 4 & 4.44E-03 \\
\hline 1 & U-235 & 1 & $7.77 \mathrm{E}+00$ & 13 & $1.40 \mathrm{E}-02$ & 4 & $1.85 \mathrm{E}-03$ \\
\hline 1 & U.236 & & & & & 4 & 4.44E-06 \\
\hline 1 & U.238 & 1 & $1.30 \mathrm{E}+01$ & 13 & $3.90 \mathrm{E}-02$ & 4 & $2.74 \mathrm{E}-03$ \\
\hline 2 & Am-241 & 6 & $3.86 \mathrm{E}+02$ & & & 114 & $7.89 \mathrm{E}-03$ \\
\hline 2 & $\mathrm{Cm}-244$ & 4 & $1.17 E+02$ & & & 98 & $9.88 \mathrm{E}-03$ \\
\hline 2 & $\mathrm{Co}-60$ & 53 & $3.05 \mathrm{E}+02$ & 22 & $9.89 \mathrm{E}-01$ & 114 & $3.56 \mathrm{E}-01$ \\
\hline 2 & Cs-134 & 4 & $3.05 \mathrm{E}+01$ & & & & \\
\hline 2 & $\mathrm{Cs}-137$ & 69 & $6.52 \mathrm{E}+03$ & 40 & $2.75 \mathrm{E}+01$ & 114 & $1.75 \mathrm{E}+00$ \\
\hline 2 & $E u-152$ & 4 & $2.24 \mathrm{E}+02$ & & & & \\
\hline 2 & $\mathrm{Eu}-154$ & 4 & $2.18 \mathrm{E}+02$ & & & & \\
\hline 2 & $\mathrm{~Pa}-234$ & 1 & $4.81 E+01$ & & & & \\
\hline 2 & Pu-238 & 35 & 9.33E-01 & 20 & $4.00 \mathrm{E}-03$ & 114 & $9.57 \mathrm{E}-04$ \\
\hline 2 & Pu-239 & 37 & $9.00 \mathrm{E}+00$ & 20 & 9.70E-02 & 114 & $1.95 \mathrm{E}-03$ \\
\hline 2 & $5 r=89$ & 3 & $1.86 \mathrm{E}+02$ & 1 & $1.18 \mathrm{E}+01$ & & \\
\hline 2 & Sr-90 & 39 & $1.04 \mathrm{E}+02$ & 80 & $2.40 \mathrm{E}+00$ & 119 & $4.89 \mathrm{E}+00$ \\
\hline 2 & Th-234 & 3 & $4.44 \mathrm{E}+01$ & & & & \\
\hline 2 & $\mathrm{H}-3$ & & & & & 119 & $8.68 E+03$ \\
\hline 2 & $\mathrm{U}-234$ & & & 20 & $5.20 \mathrm{E}-02$ & 4 & $2.92 \mathrm{E}-03$ \\
\hline 2 & U-235 & 6 & $3.21 E+01$ & 20 & $5.00 \mathrm{E}-03$ & 4 & $1.85 \mathrm{E}-03$ \\
\hline 2 & $\mathrm{U}-236$ & & & & & 4 & $5.18 \mathrm{E}-06$ \\
\hline 2 & U-238 & 6 & $4.32 \mathrm{E}+02$ & 20 & $3.10 \mathrm{E}-02$ & 4 & $2.07 \mathrm{E}-03$ \\
\hline 3 & Am-241 & 2 & $1.04 \mathrm{E}+00$ & & & & \\
\hline 3 & $\mathrm{Cm}-244$ & 2 & $2.59 \mathrm{E}-01$ & & & & \\
\hline 3 & $\mathrm{Co}-60$ & 69 & $3.70 \mathrm{E}+01$ & & & & \\
\hline 3 & $\mathrm{Cs}-134$ & 3 & $3.54 \mathrm{E}+00$ & & & & \\
\hline 3 & $\mathrm{Cs}-137$ & 85 & $5.09 \mathrm{E}+01$ & & & & \\
\hline 3 & $\mathrm{~Pa}-233$ & 2 & $9.43 \mathrm{E}-01$ & & & & \\
\hline 3 & $\mathrm{~Pa}-234$ & 2 & $2.04 \mathrm{E}+02$ & & & & \\
\hline 3 & Pu-238 & 1 & $2.96 \mathrm{E}-01$ & & & & \\
\hline$a$ & Pu-239 & 2 & $1.18 \mathrm{E}+00$ & & & & \\
\hline
\end{tabular}


Table B6 (continued)

\begin{tabular}{|c|c|c|c|c|c|c|c|}
\hline Roach & Radionuclide & $N$ & $\begin{array}{c}\text { Sediment } \\
\text { (Bq/kg, dry) }\end{array}$ & $N$ & $\begin{array}{c}\text { Fish } \\
(\mathrm{Bq} / \mathrm{kg} \text {, wet) }\end{array}$ & $N$ & $\begin{array}{l}\text { Wator } \\
(\mathrm{Bq} / \mathrm{L})\end{array}$ \\
\hline 3 & Sr-90 & 4 & $6.48 \mathrm{E}+00$ & 11 & $1.38 \mathrm{E}-01$ & & \\
\hline 3 & Tc- 99 & & & 4 & $2.04 \mathrm{E}+00$ & & \\
\hline 3 & Th-234 & 4 & $1.34 \mathrm{E}+02$ & & & & \\
\hline 3 & U.235 & 9 & $8.16 \mathrm{E}+01$ & & & & \\
\hline 3 & U.238 & 13 & $8.68 \mathrm{E}+02$ & & & & \\
\hline 4 & Am-241 & 2 & $5.80 \mathrm{E}+00$ & & & & \\
\hline 4 & $\mathrm{Cm}-244$ & 2 & $1.13 \mathrm{E}+00$ & & & & \\
\hline 4 & Co- 60 & 39 & $3.35 \mathrm{E}+01$ & 33 & 2.51E-01 & & \\
\hline 4 & Cs-137 & 52 & $6.03 E+02$ & 49 & $5.74 E+00$ & & \\
\hline 4 & Pu-238 & 34 & 4.44E-01 & 33 & $3.00 \mathrm{E}-03$ & & \\
\hline 4 & Pu-239 & 34 & $5.60 \mathrm{E}+00$ & 33 & $3.00 \mathrm{E}-03$ & & \\
\hline 4 & $\mathrm{Sr}-89$ & 2 & $1.57 \mathrm{E}+01$ & 1 & $7.40 \mathrm{E}-01$ & & \\
\hline 4 & Sr-90 & 34 & $2.54 E+01$ & 58 & $5.30 \mathrm{E}-01$ & 4 & $1.11 \mathrm{E}-01$ \\
\hline 4 & Tc-99 & & & 4 & $2.22 \mathrm{E}+00$ & & \\
\hline 4 & Th-234 & 2 & $8.23 E+01$ & & & & \\
\hline 4 & H-3 & & & & & 4 & $5.55 \mathrm{E}+01$ \\
\hline 4 & U-234 & & & 33 & $1.44 \mathrm{E}-01$ & 4 & 2.92E-03 \\
\hline 4 & U.235 & 2 & $3.31 \mathrm{E}+01$ & 33 & $2.00 \mathrm{E}-0.2$ & 4 & $1.85 \mathrm{E}-03$ \\
\hline 4 & $\mathrm{U}-236$ & & & & & 4 & $1.07 \mathrm{E}-05$ \\
\hline 4 & U.238 & 3 & $2.92 \mathrm{E}+02$ & 33 & $8.70 \mathrm{E}-02$ & 4 & $1.96 \mathrm{E} \cdot 03$ \\
\hline 5 & $\mathrm{Co}-60$ & 189 & $5.53 E+00$ & & & & \\
\hline 5 & $\mathrm{C}=-137$ & 201 & $7.81 E+01$ & & & & \\
\hline 5 & Pu-238 & 6 & $1.20 \mathrm{E}-01$ & & & & \\
\hline 5 & Pu-239 & 6 & $1.19 \mathrm{E}+00$ & & & & \\
\hline 5 & $\mathrm{Sr}-90$ & 6 & $2.47 E+01$ & & & & \\
\hline 10 & Am-241 & 1 & $4.81 \mathrm{E}-01$ & & & & \\
\hline 10 & $\mathrm{Cm} \cdot 244$ & 1 & $1.85 \mathrm{E}-01$ & & & & \\
\hline 10 & Cs-137 & 2 & $3.15 \mathrm{E}+01$ & & & & \\
\hline 10 & $\mathrm{Sr}-89$ & 2 & $9.25 \mathrm{E}+01$ & & & & \\
\hline io & Sr-90 & 2 & $7.40 \mathrm{E}+00$ & & & & \\
\hline 18 & Cs- 137 & 6 & $9.13 E+00$ & & & & \\
\hline
\end{tabular}

$N=$ Number of observations that make up the mean value. 
Appendix C

RESULTS OF CONSERVATTVE SCREENING 


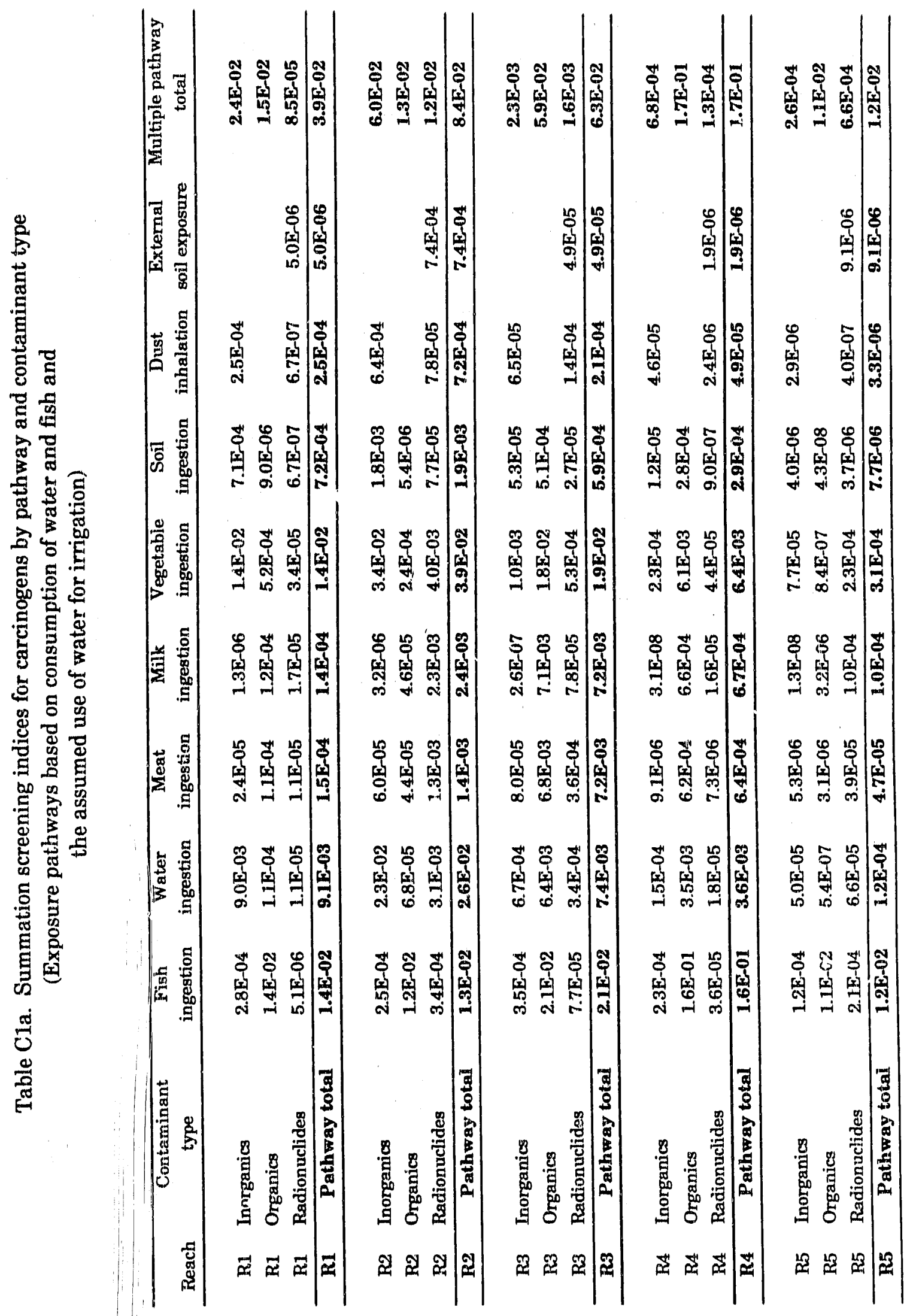




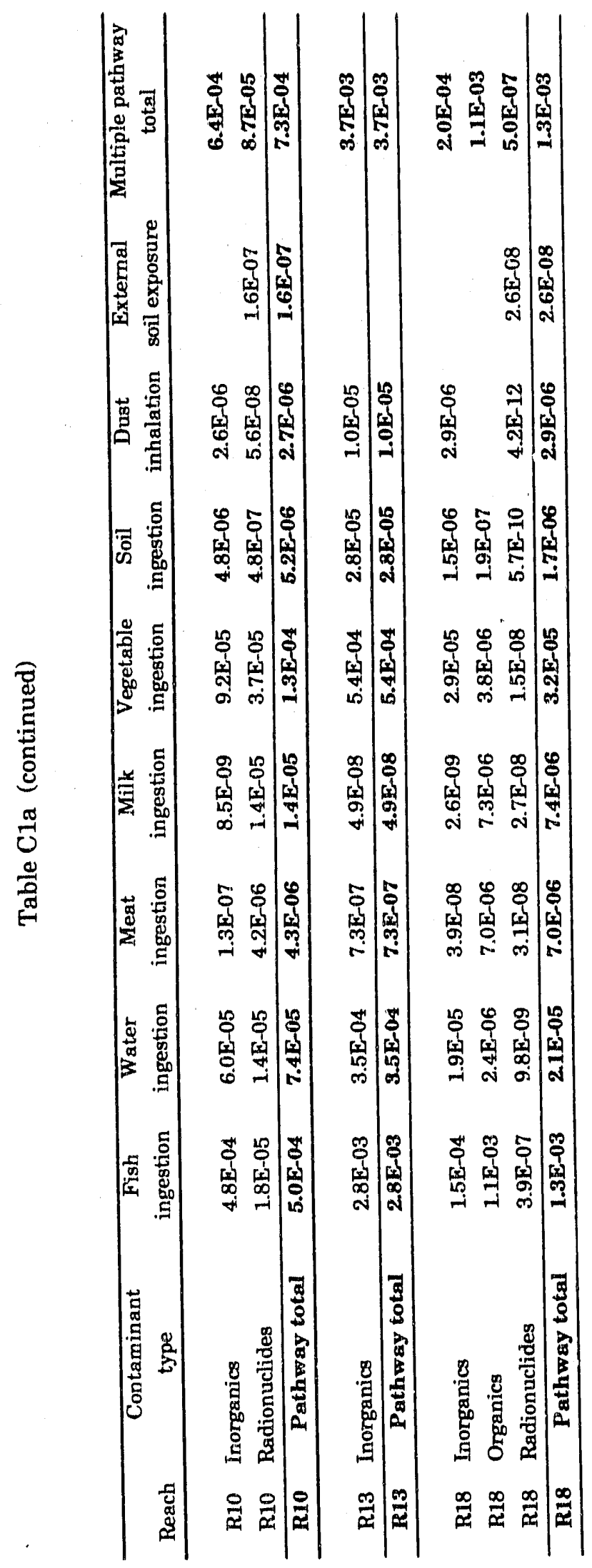



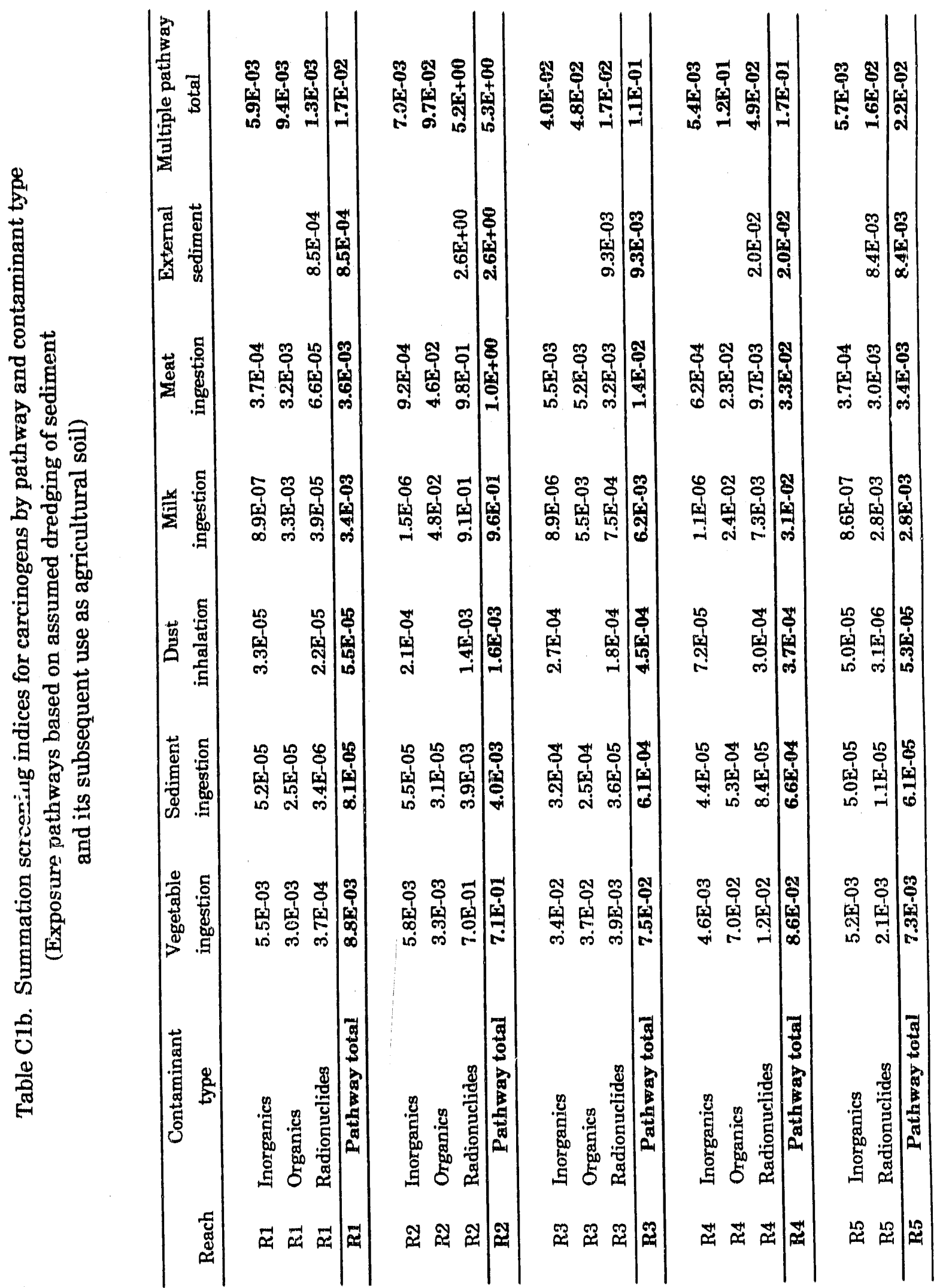


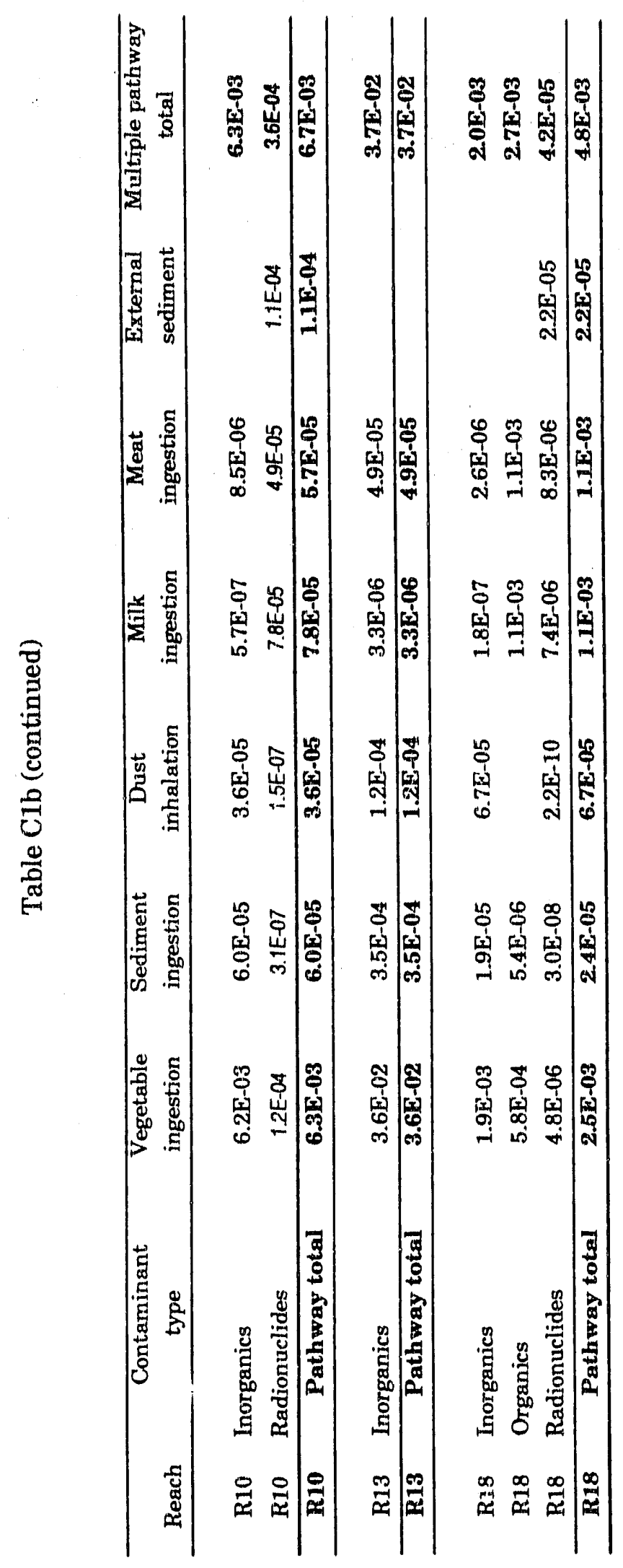




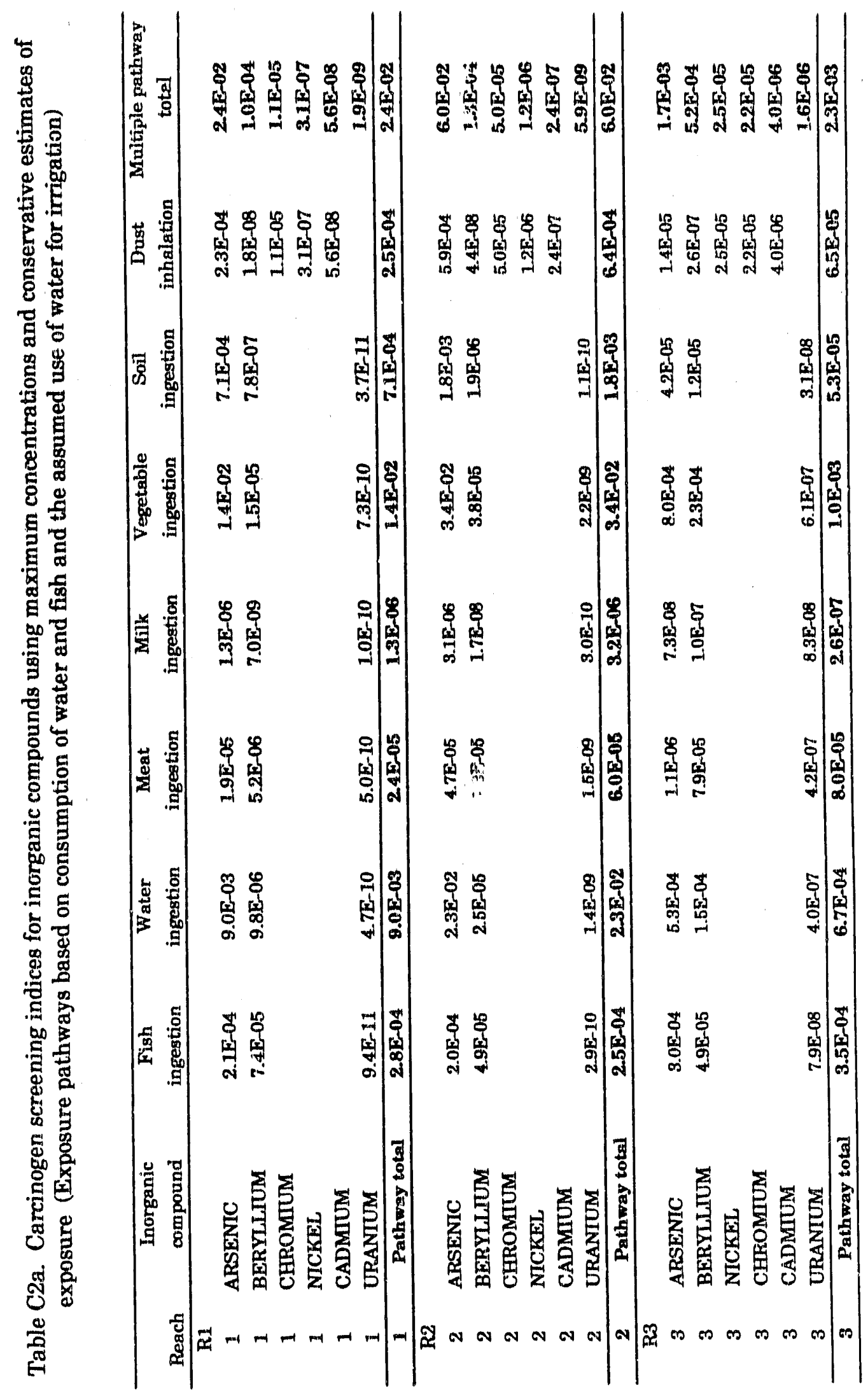




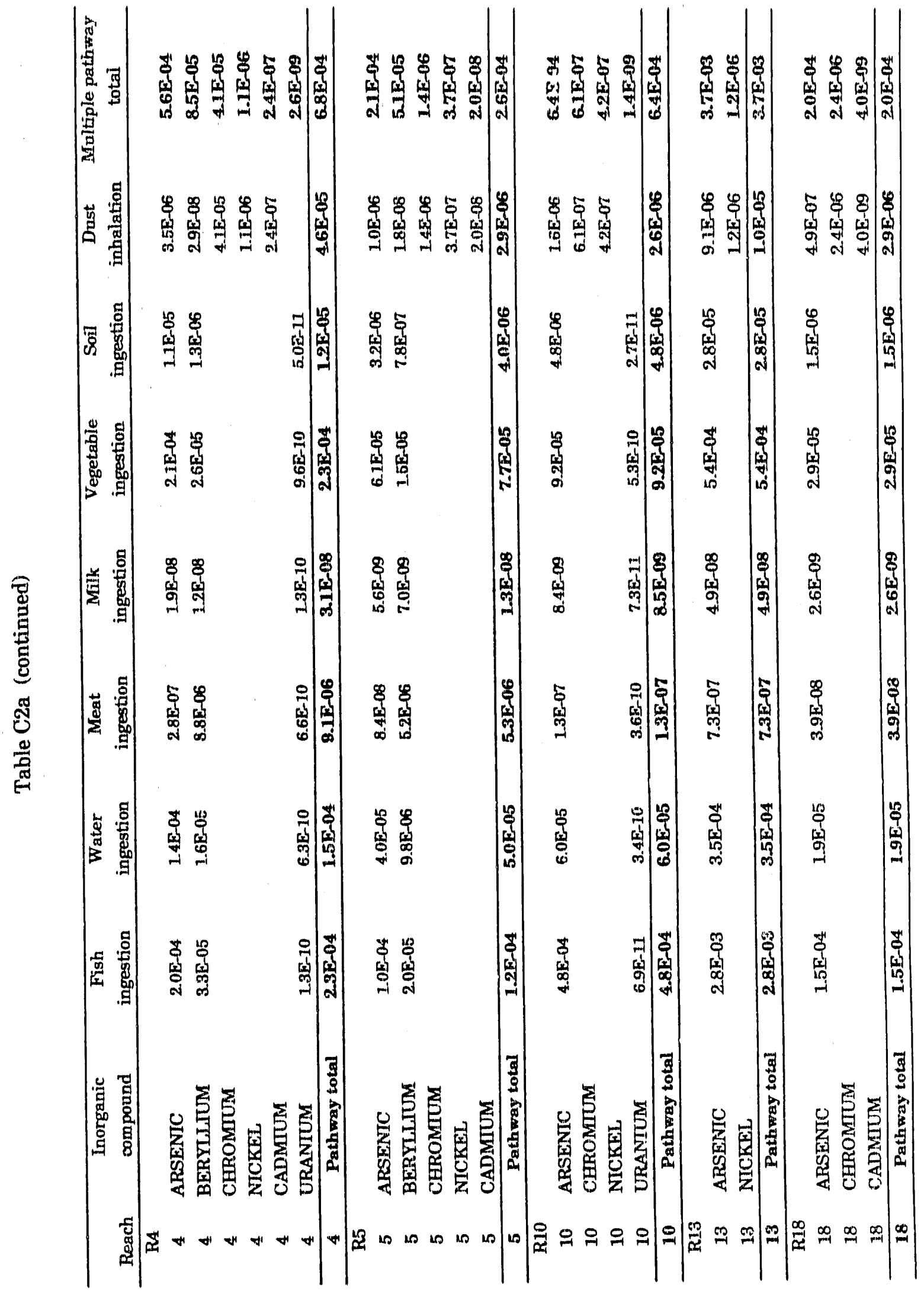


7

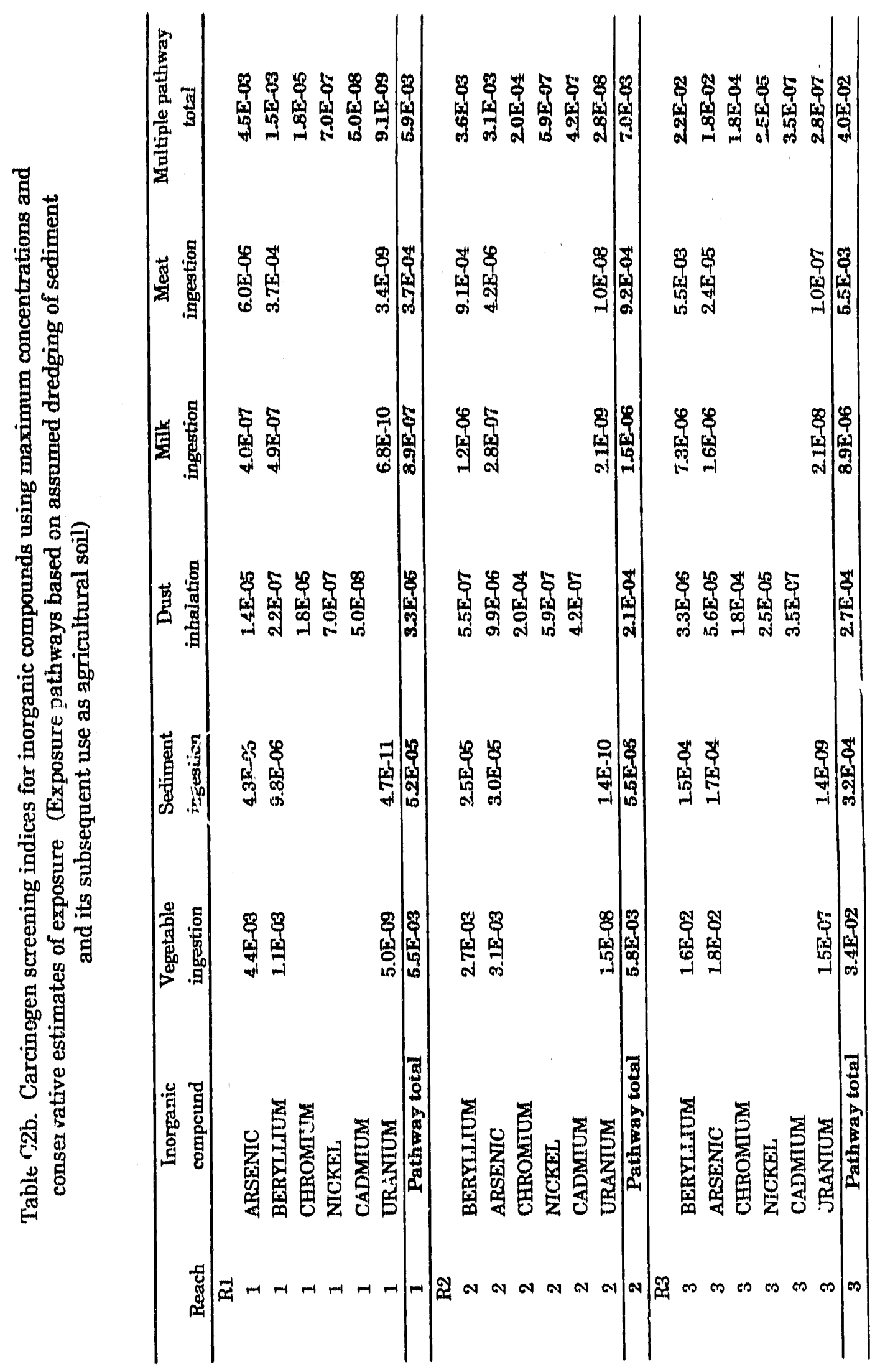




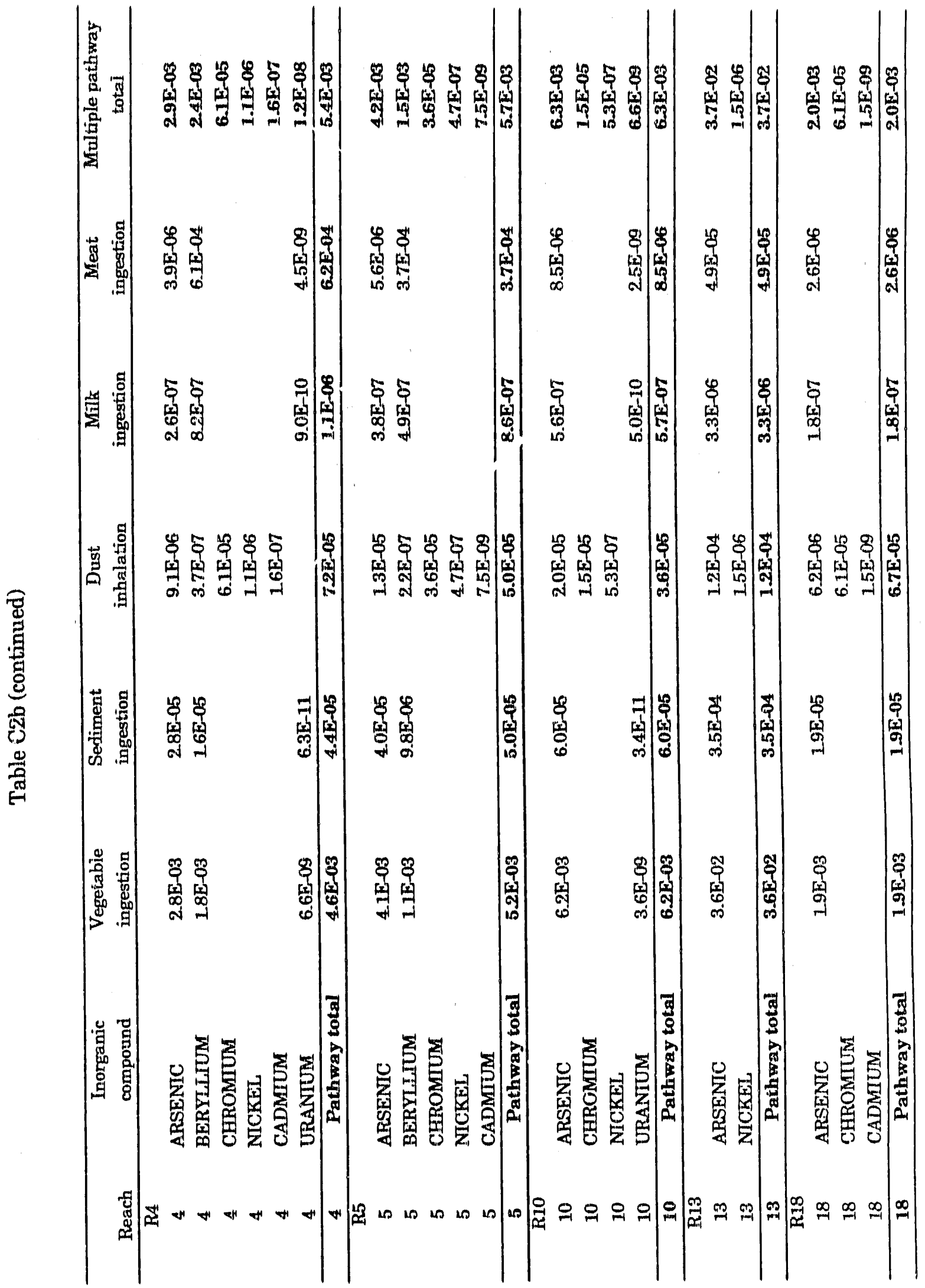




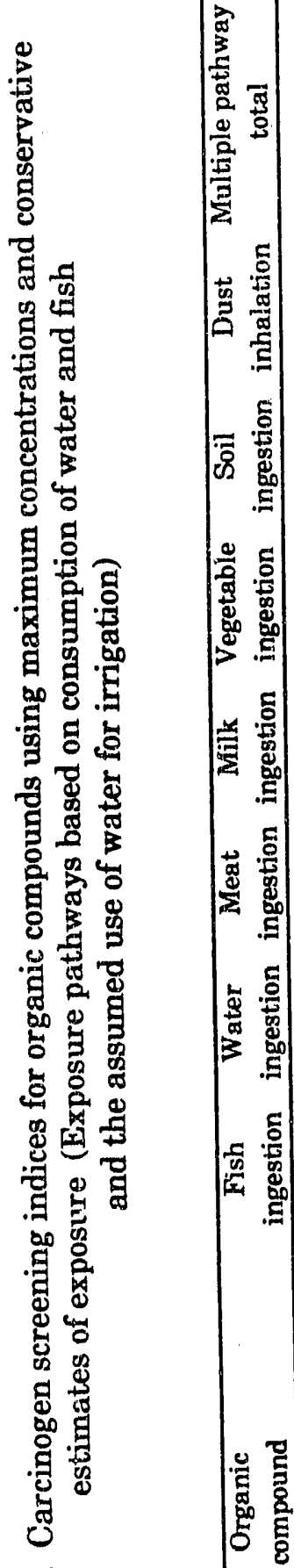

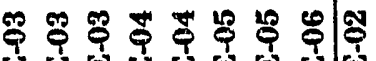

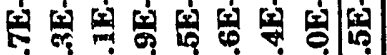

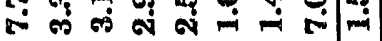

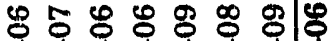

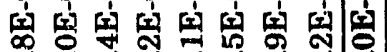

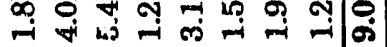

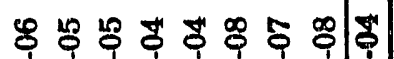

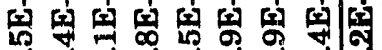

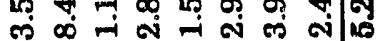

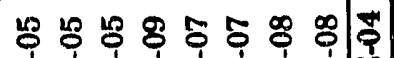

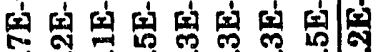
$\infty$ -

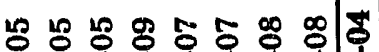

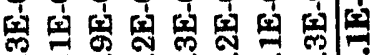
我 $\rightarrow$ -

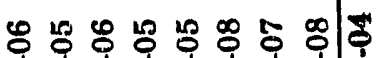

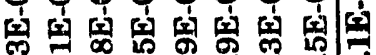

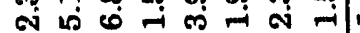

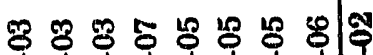

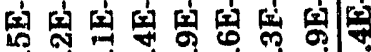
مै

बึ่ 章

\section{- \\ 总茶罢 安语空

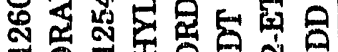

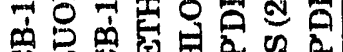

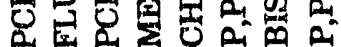

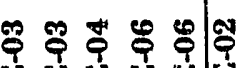

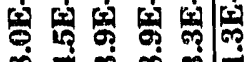
$\infty+\infty \infty$

ஃ ㄷㅇㅇㅇㅇㅇ

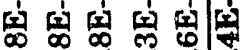
เి

\& 8 \&

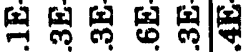
- के จ

낭 냉 5ㅇㅇㅇ

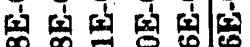
ஸ

농 눙 $500 \%$

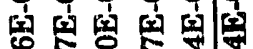

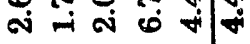
58 की मे m \%

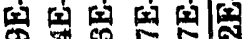
वृ

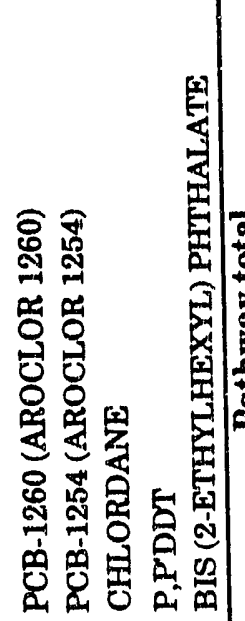

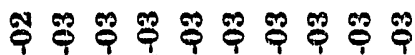

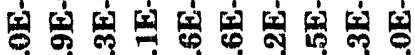

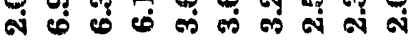

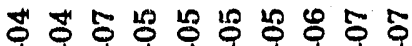

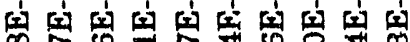

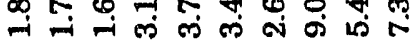

융 ஜ \&

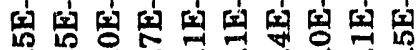

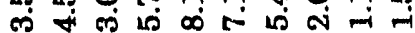

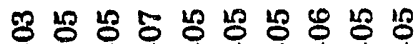

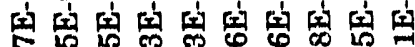

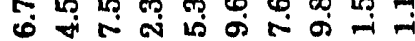

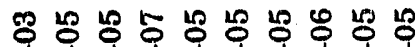

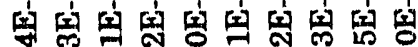

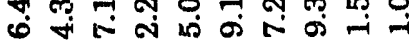

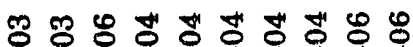

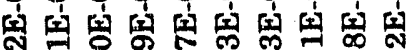

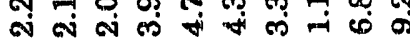

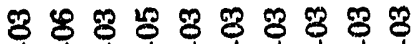

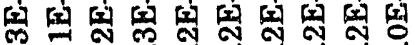
-

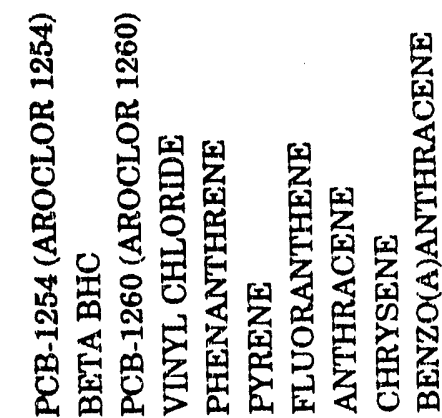




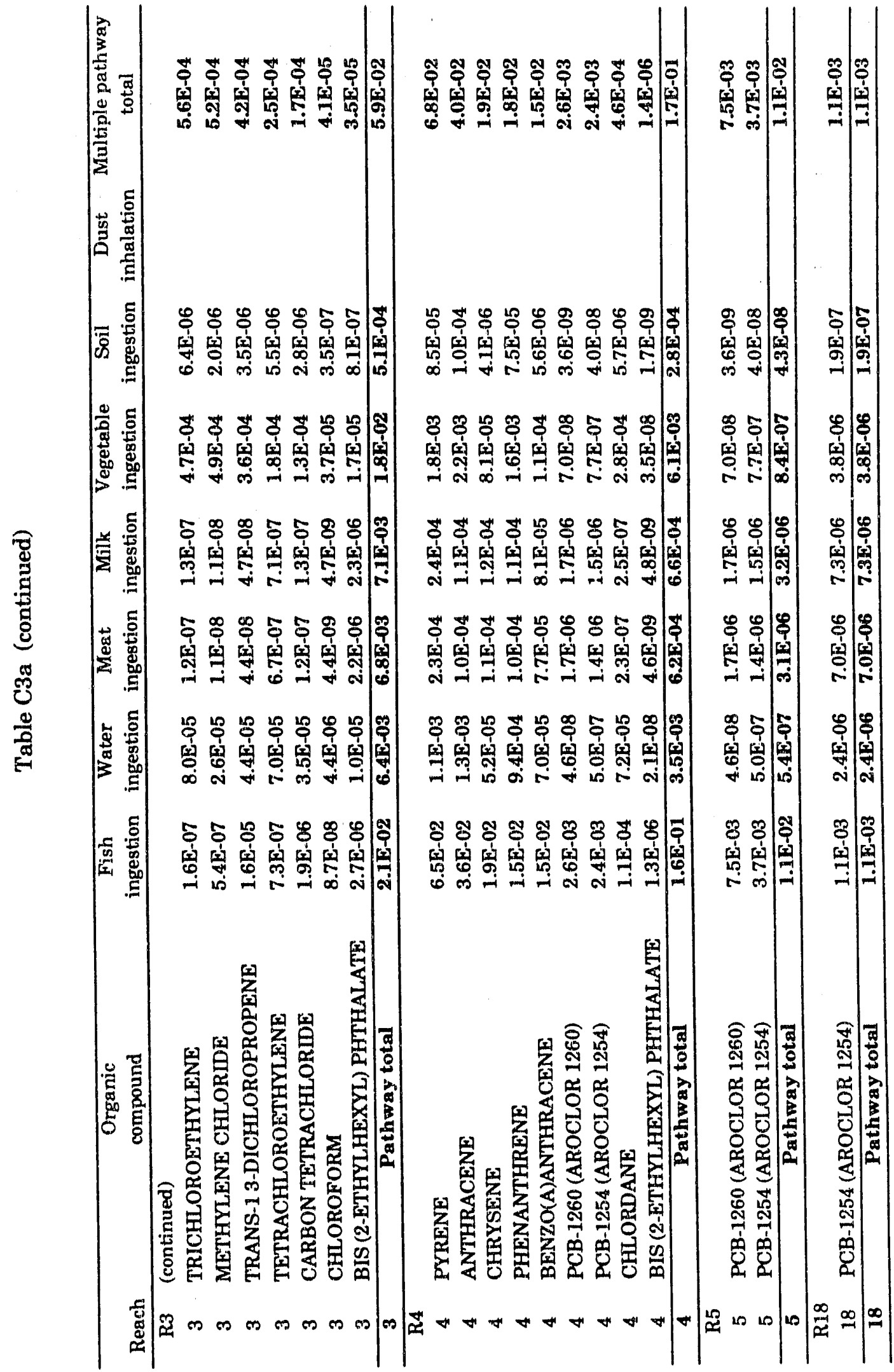




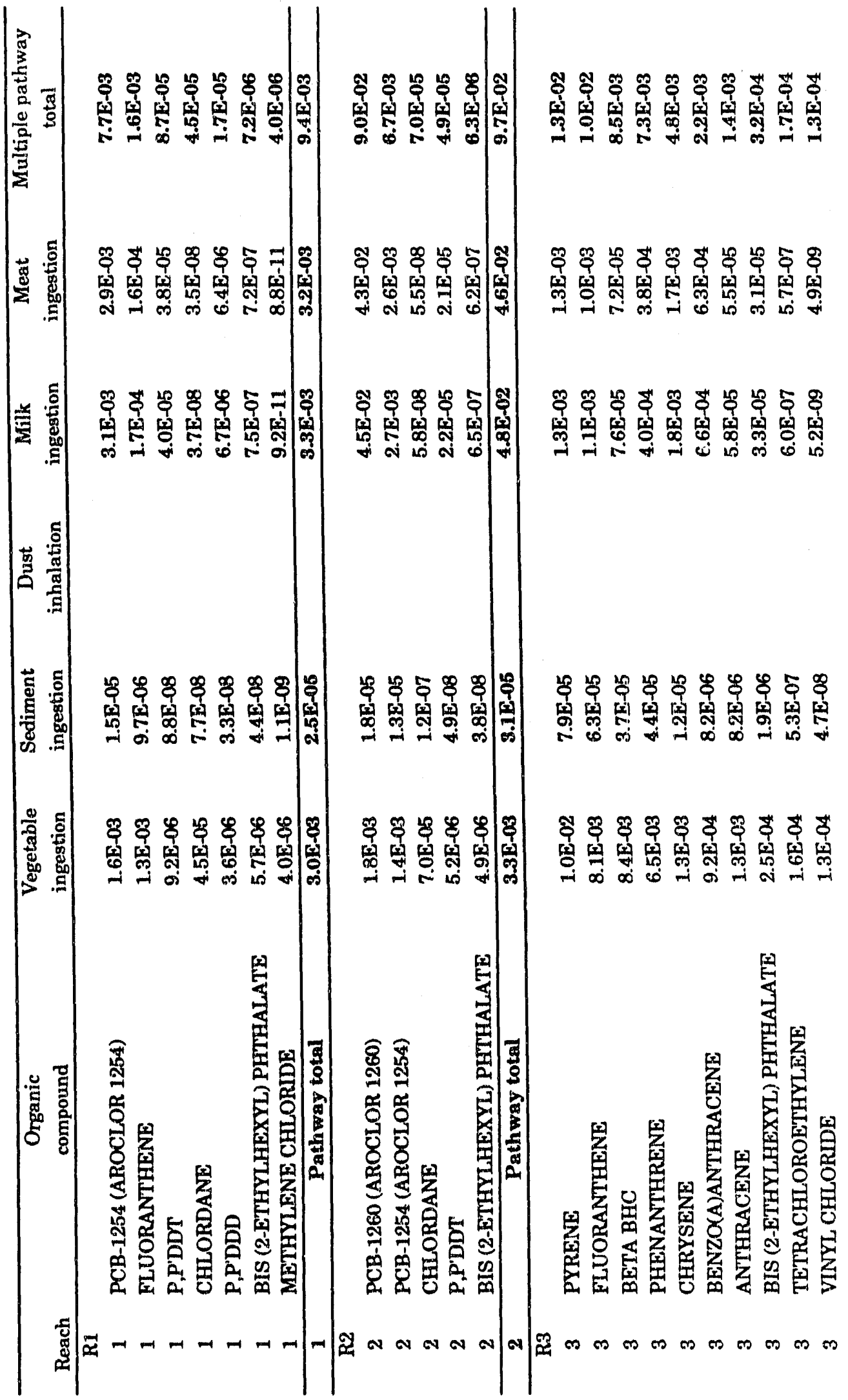




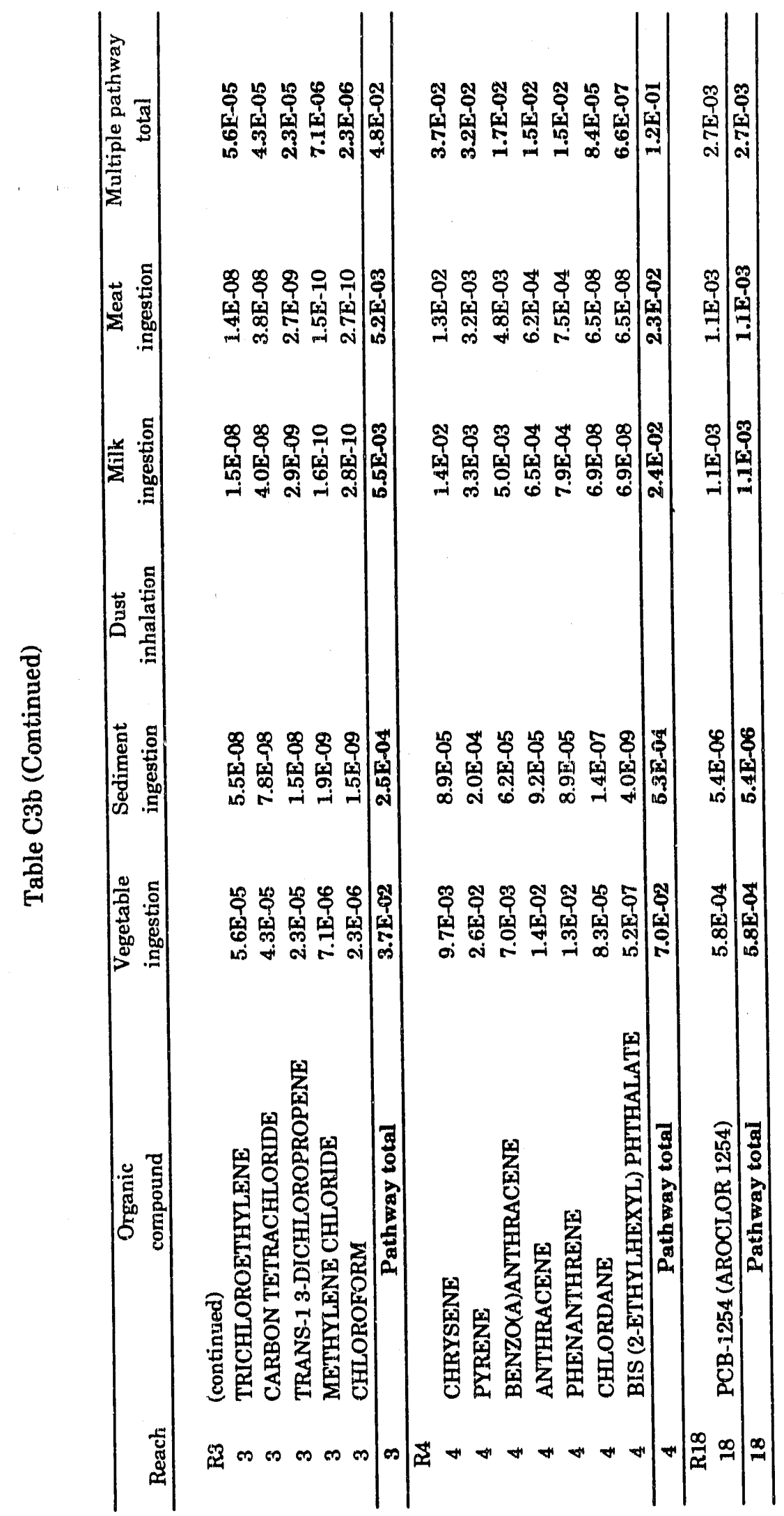




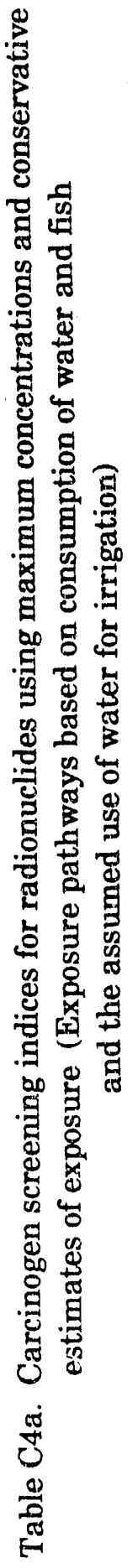

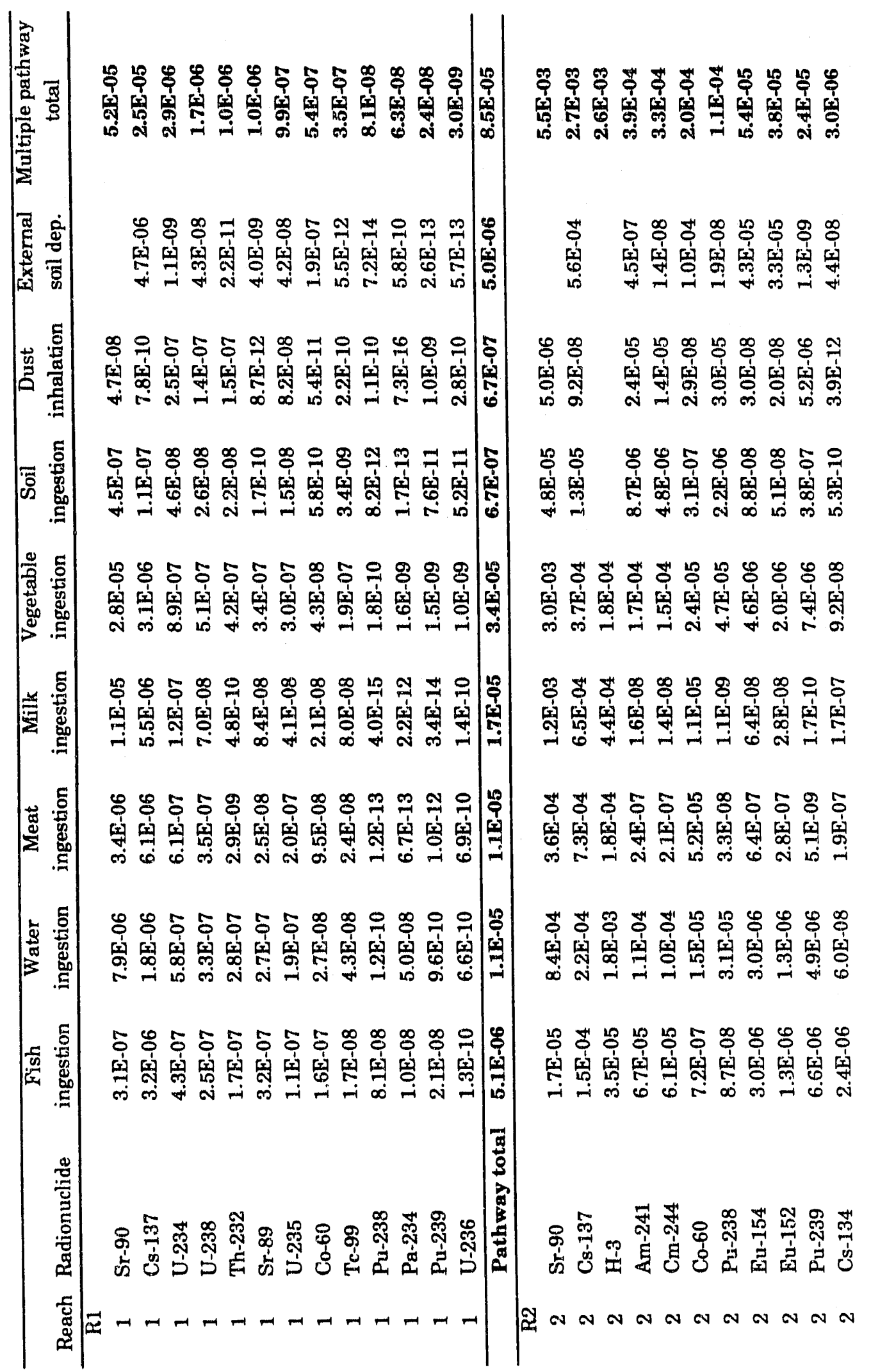




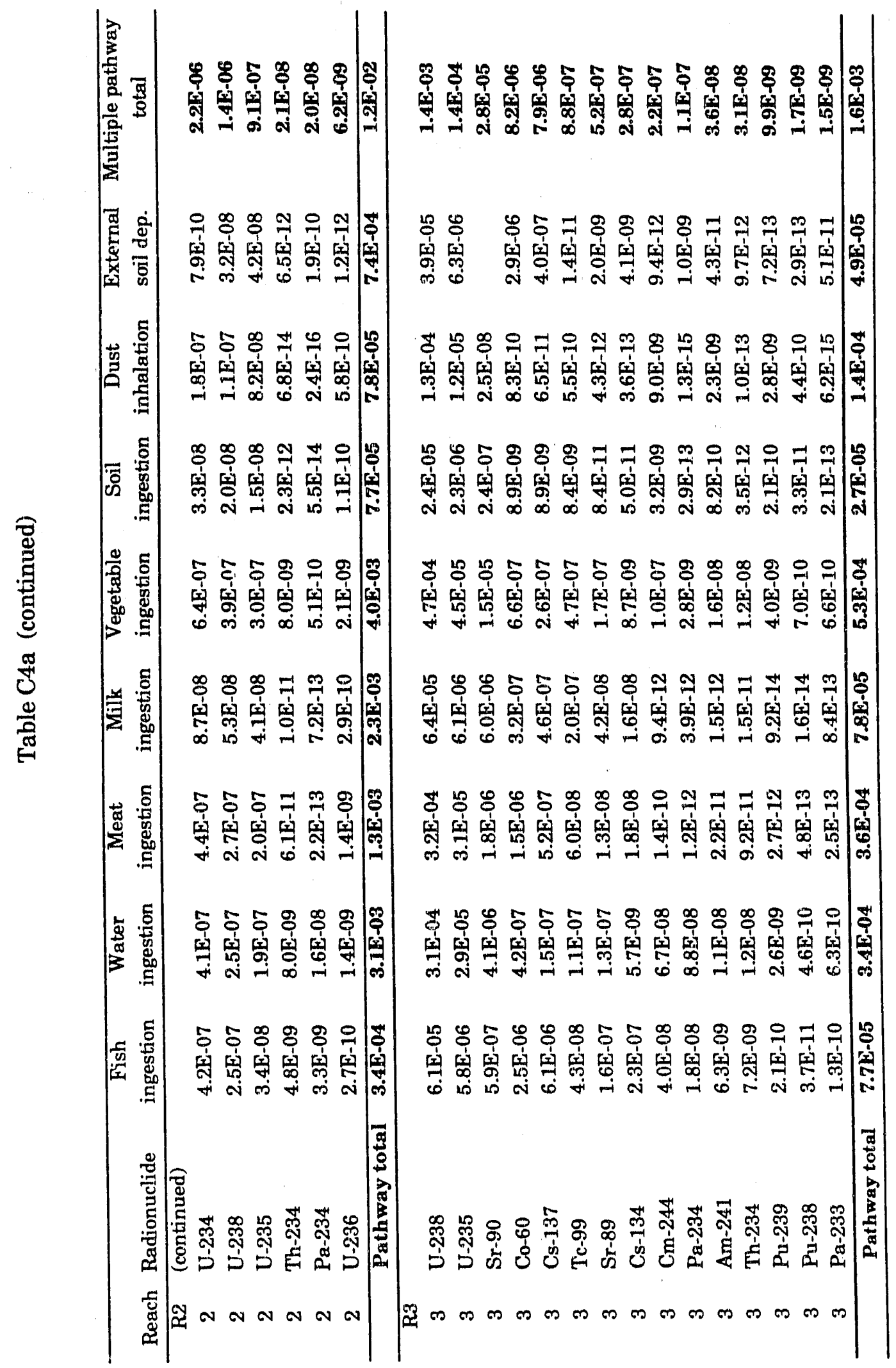




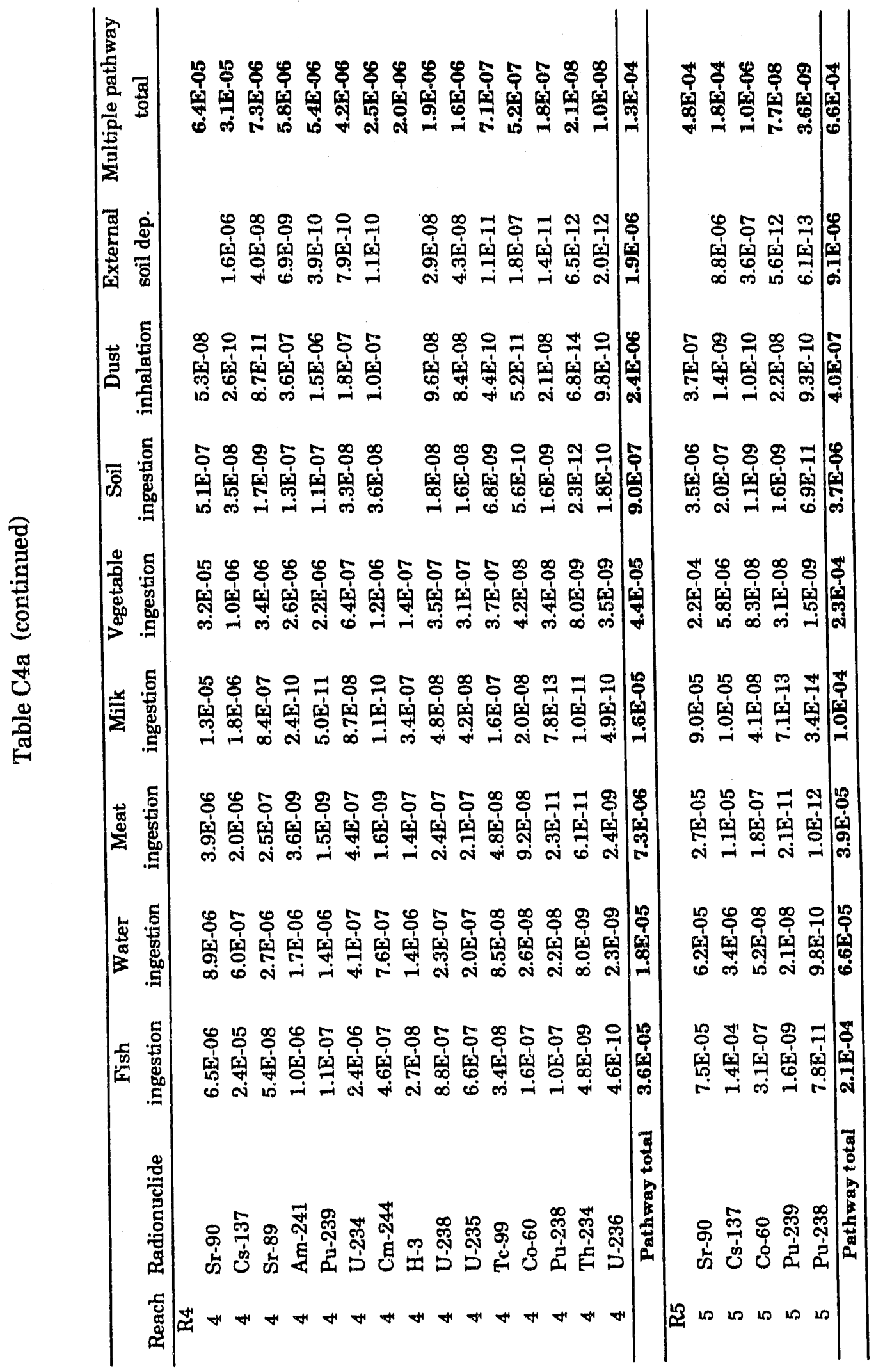




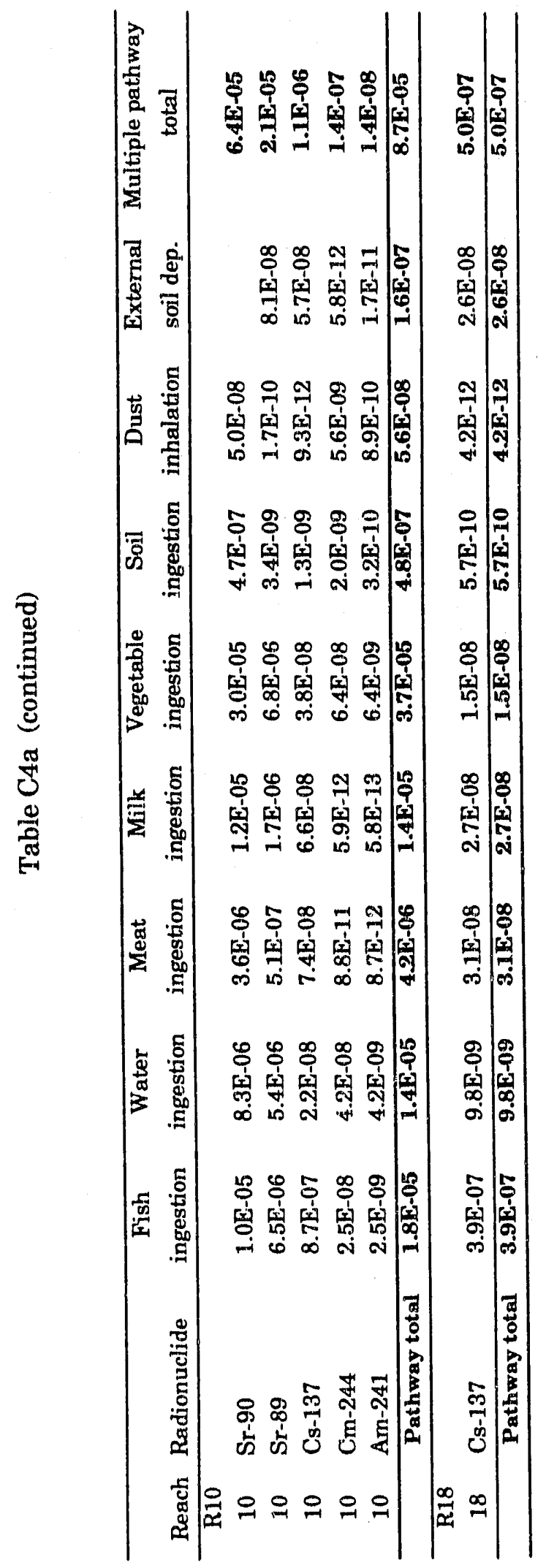





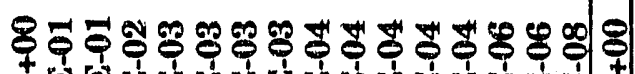

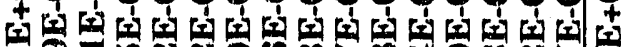
-

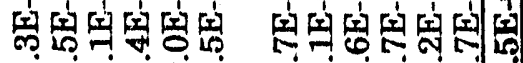

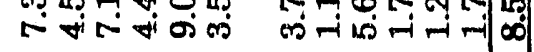

8
0
된
오

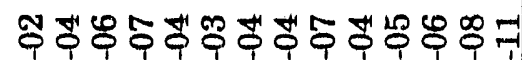

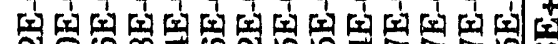
ง 00 \%

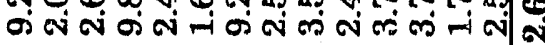

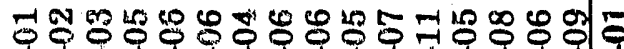

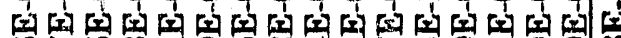
以승

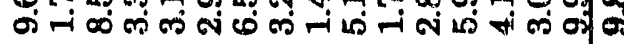

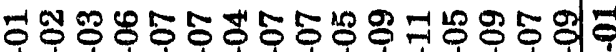

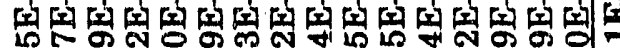

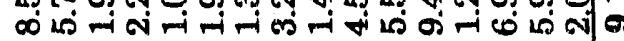

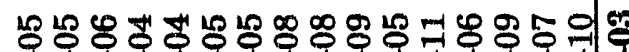

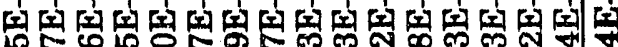
ज्ञ की

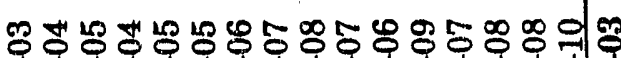

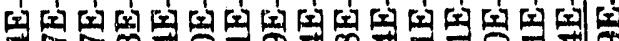

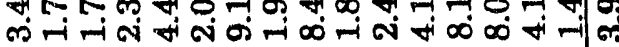

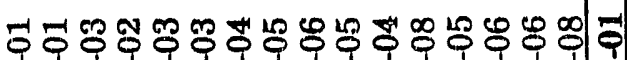

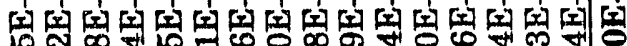

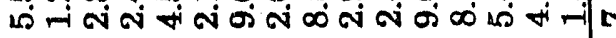

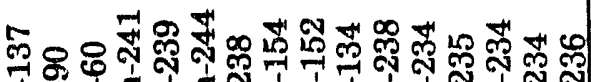

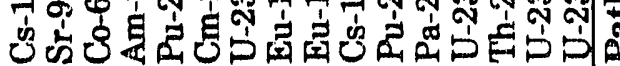

कु 


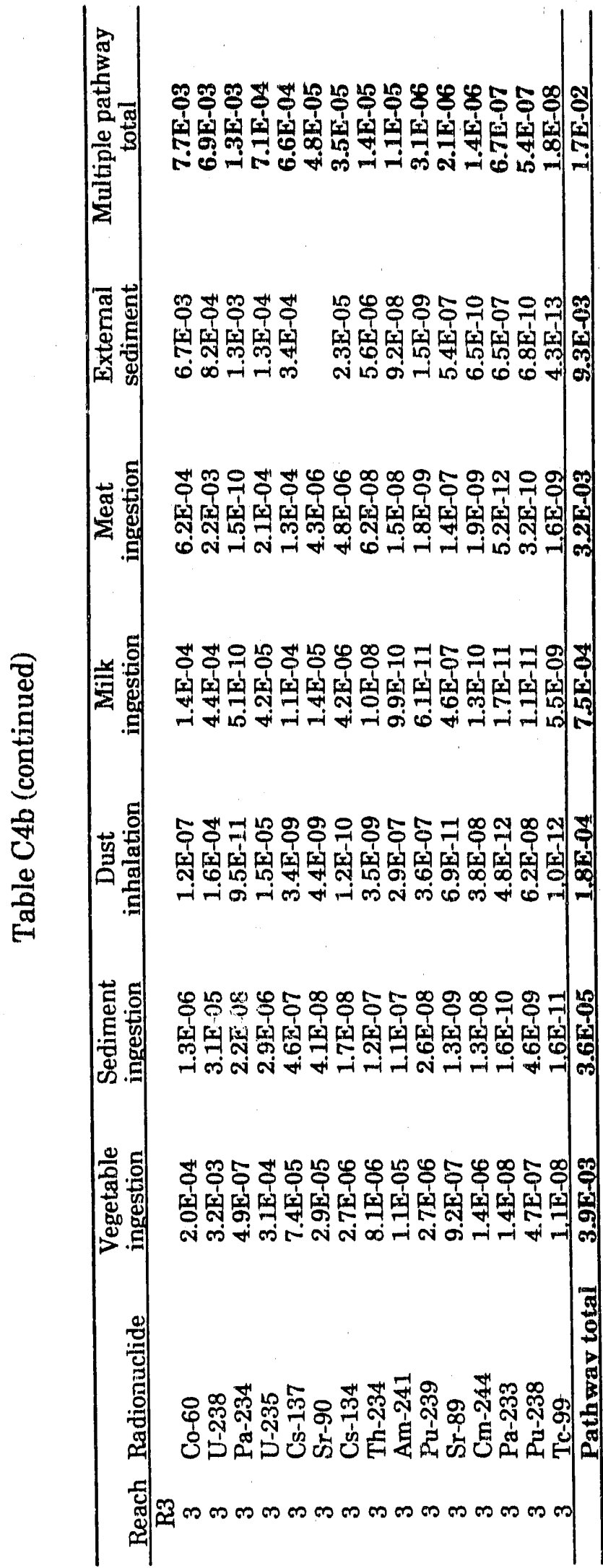

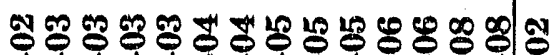
th

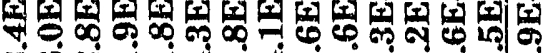
का $\infty$ जं

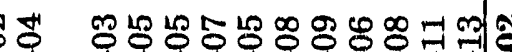

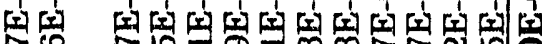
No NLO - का मां

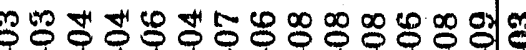

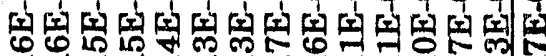

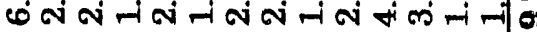

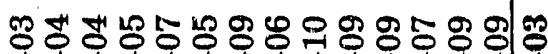
पे 舟 10 10000 का

ธல்

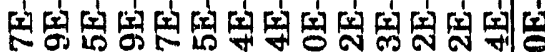

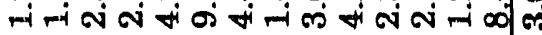

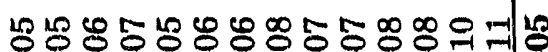

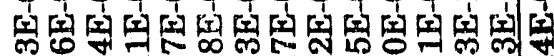

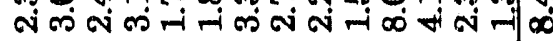

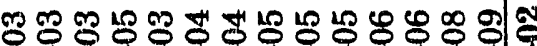

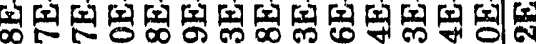

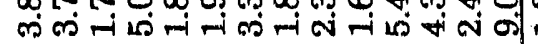




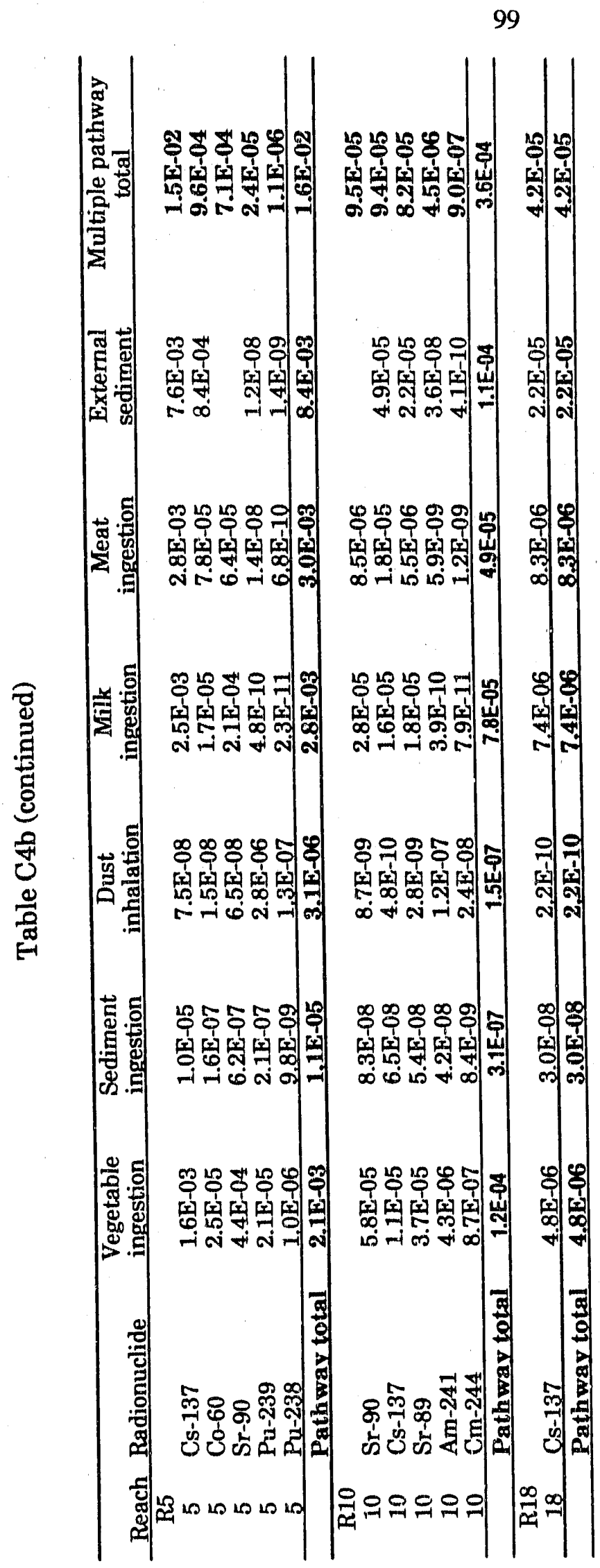




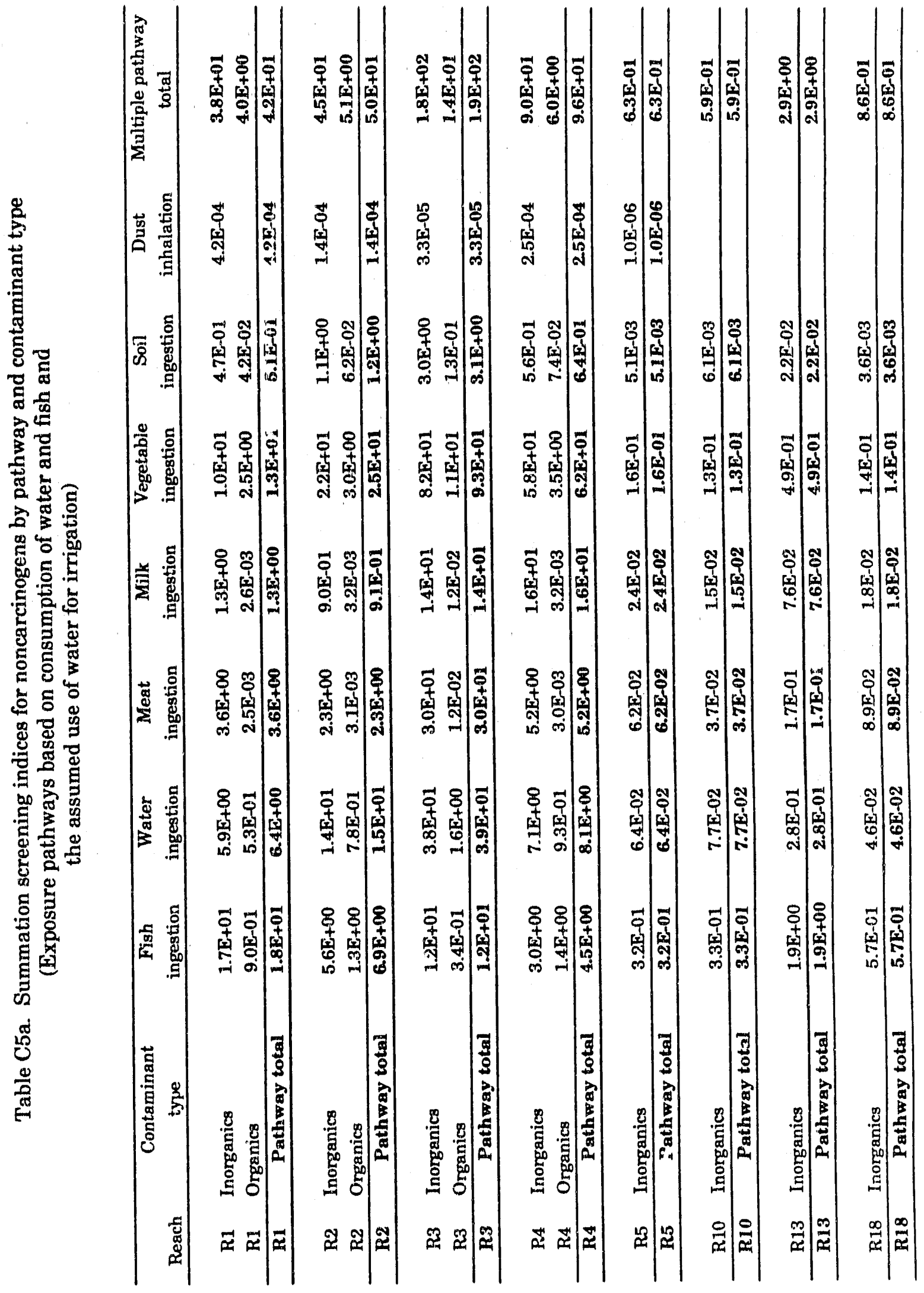




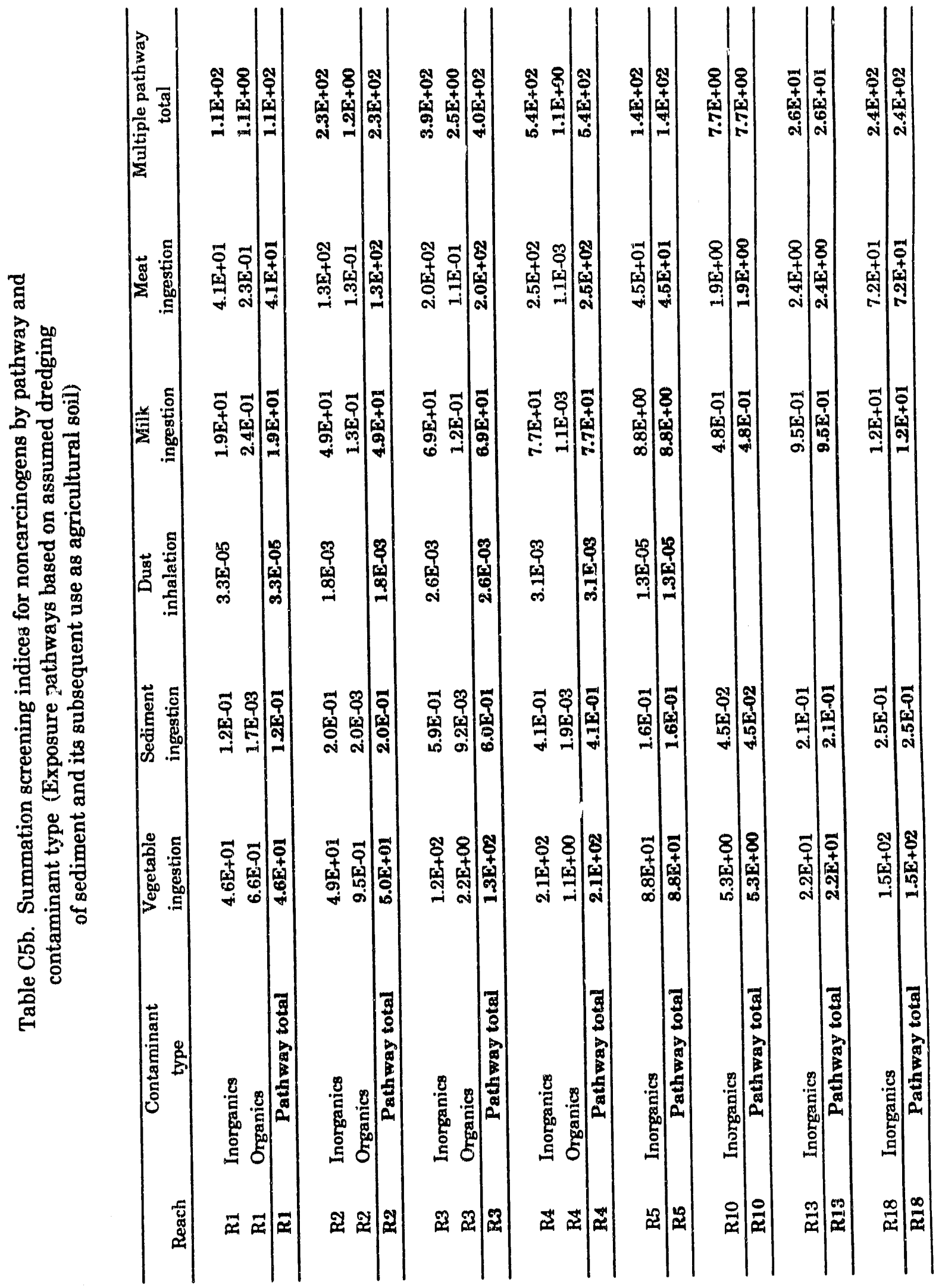



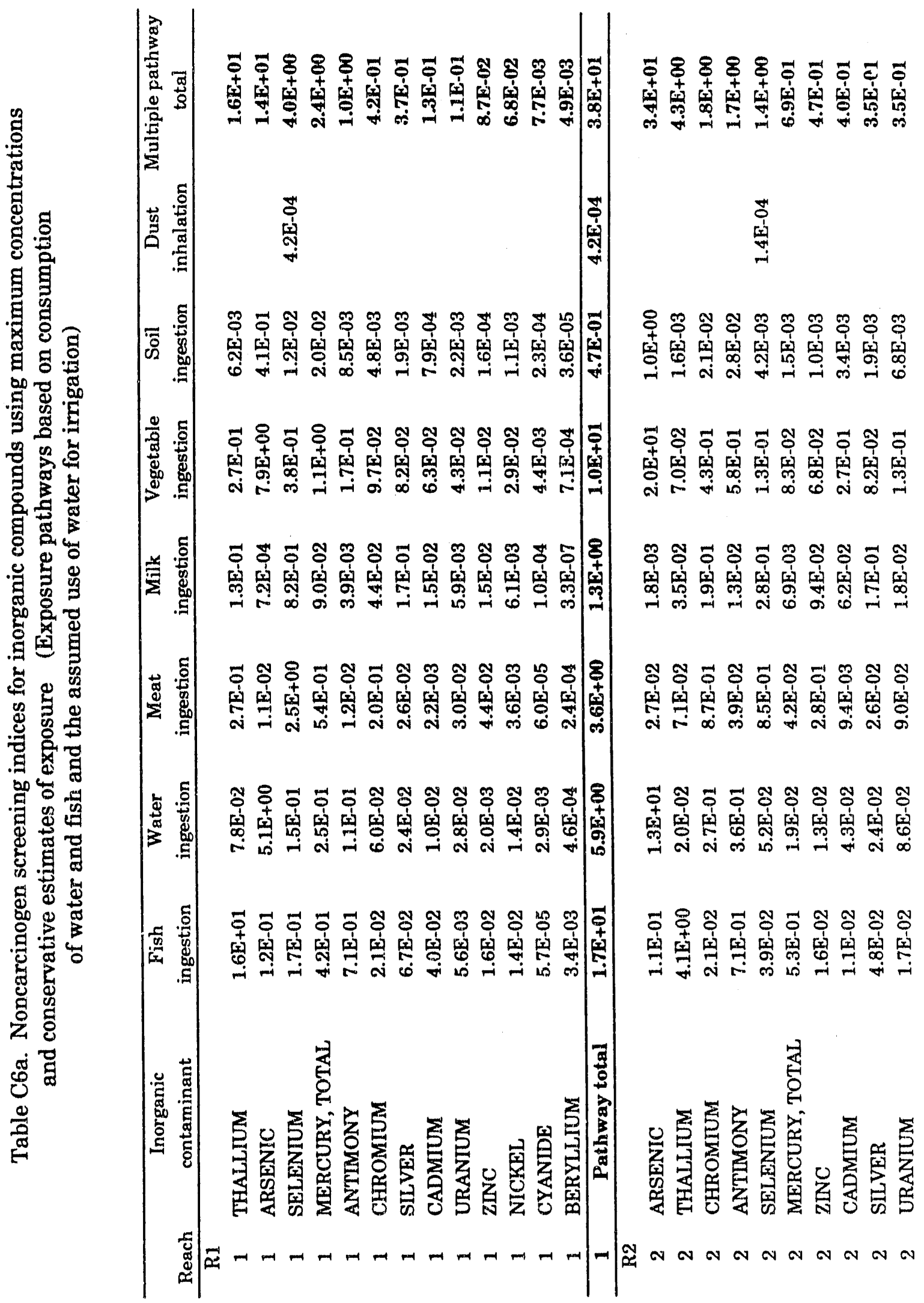


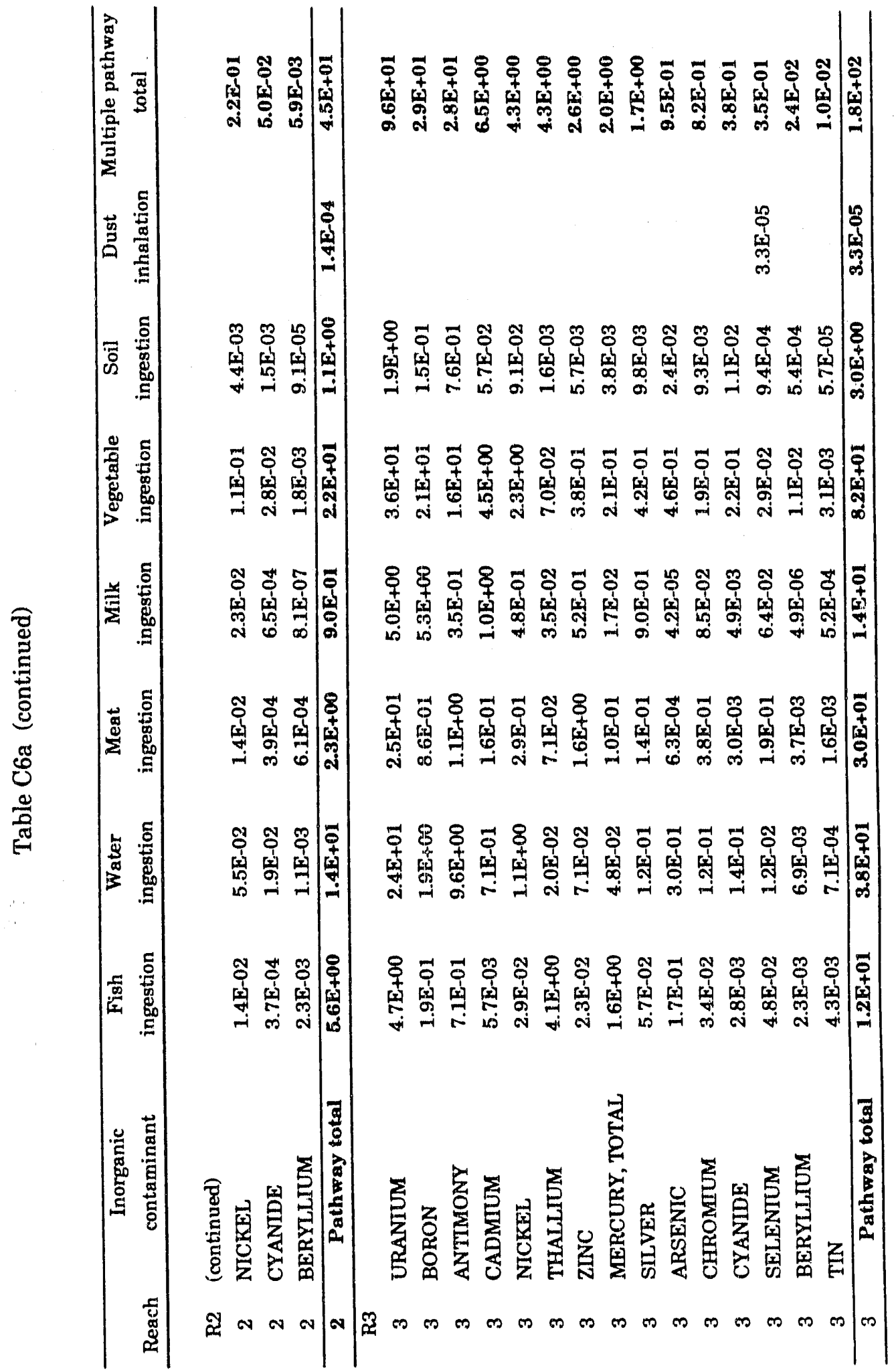




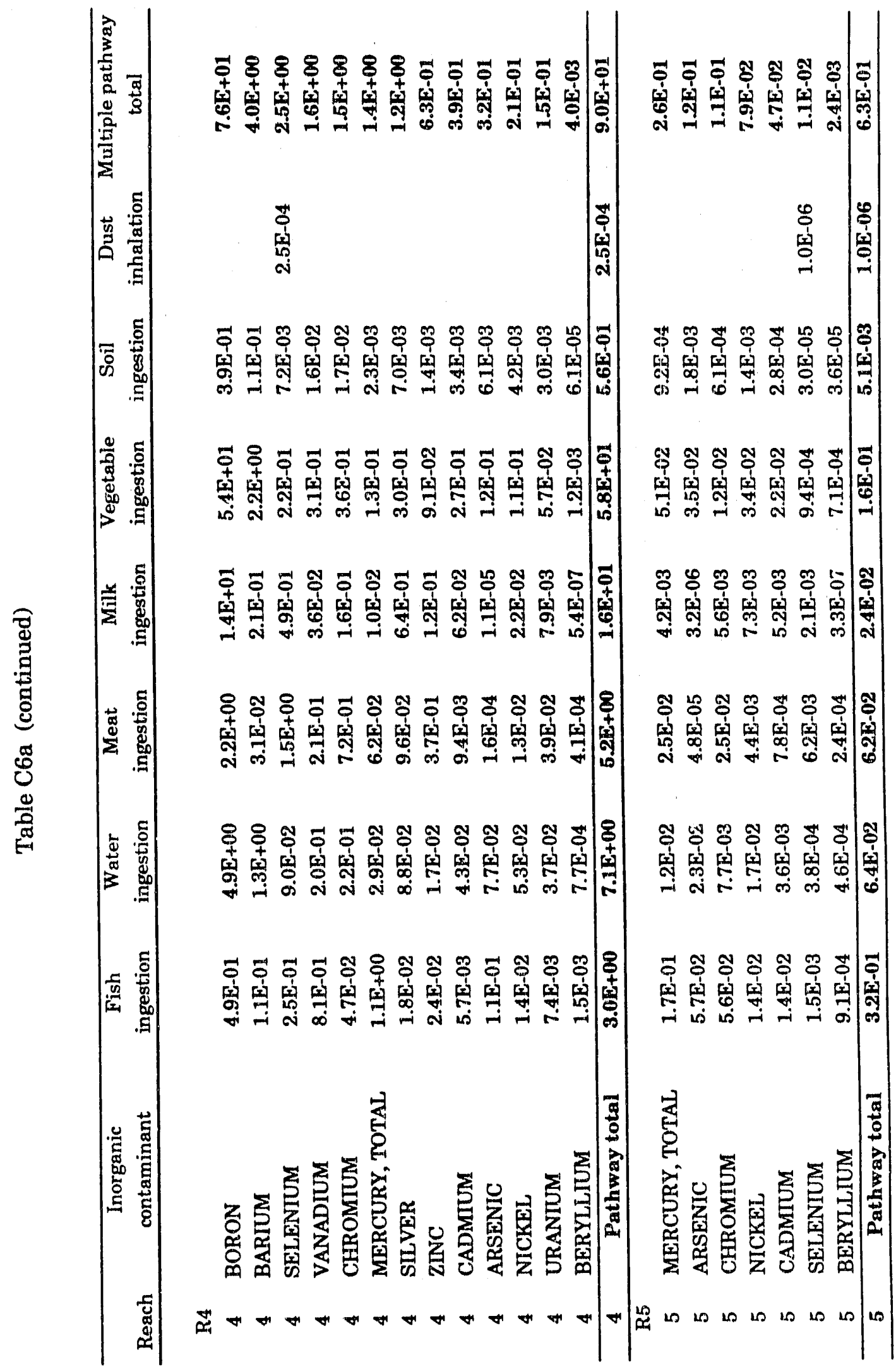




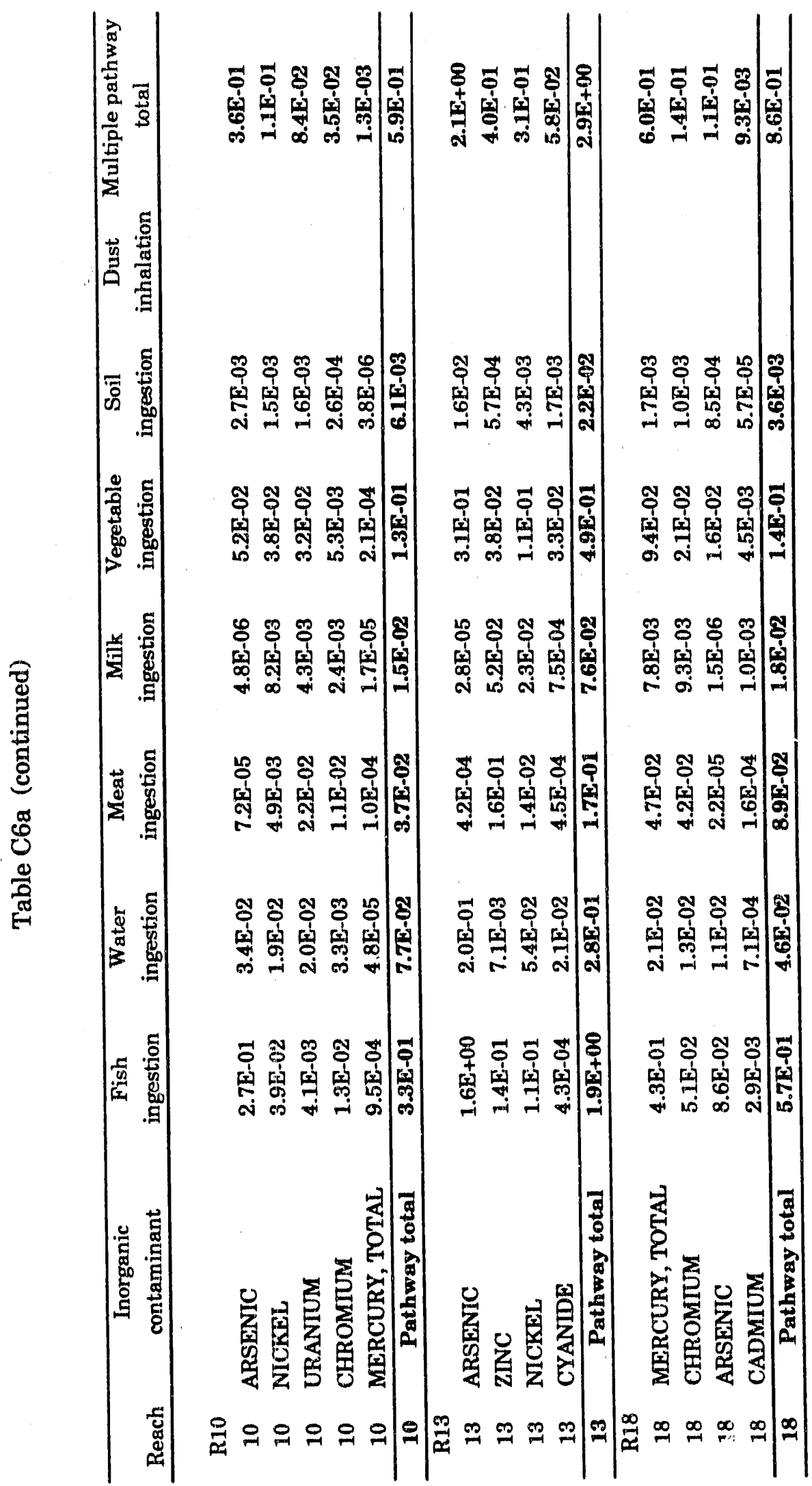




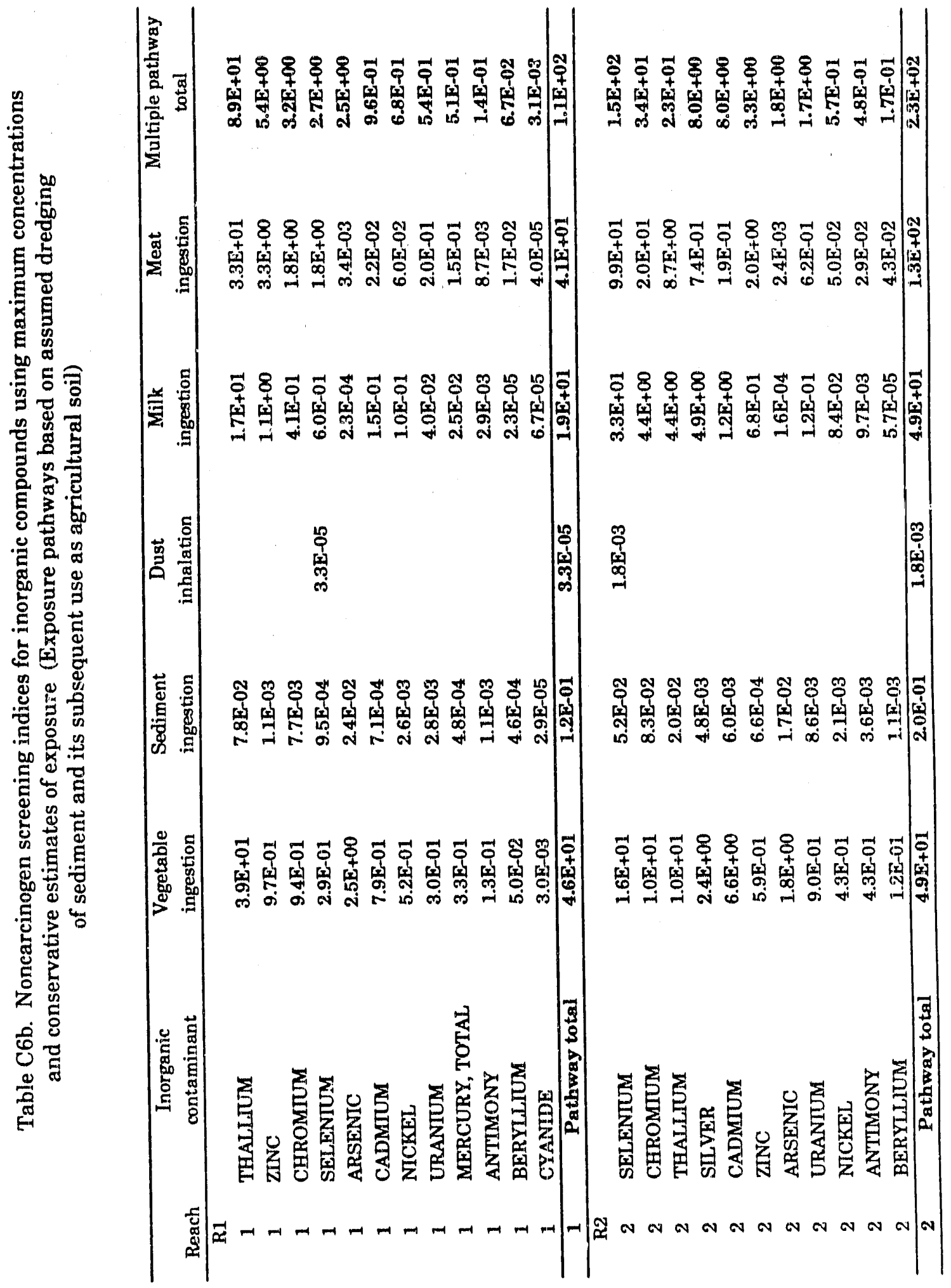




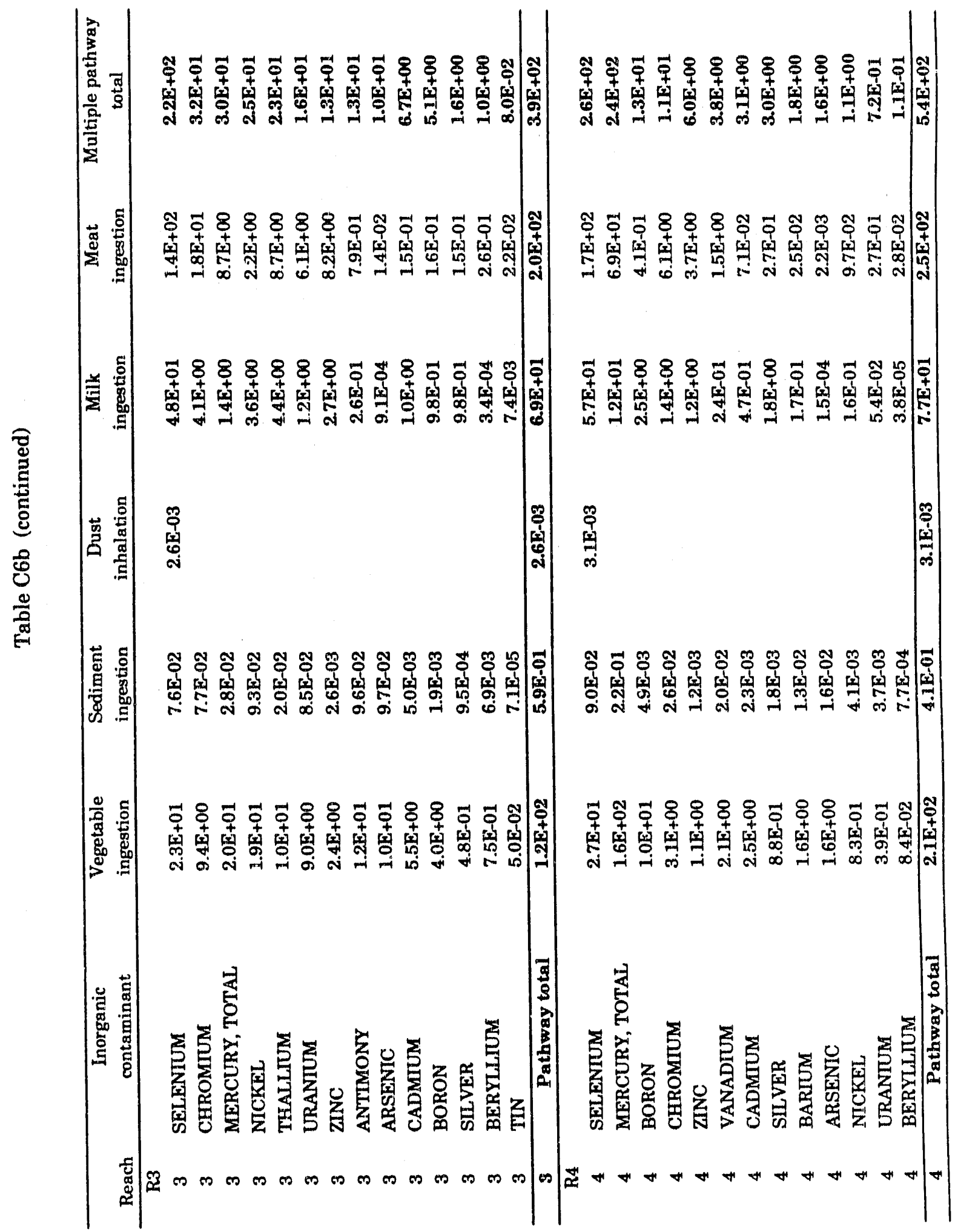




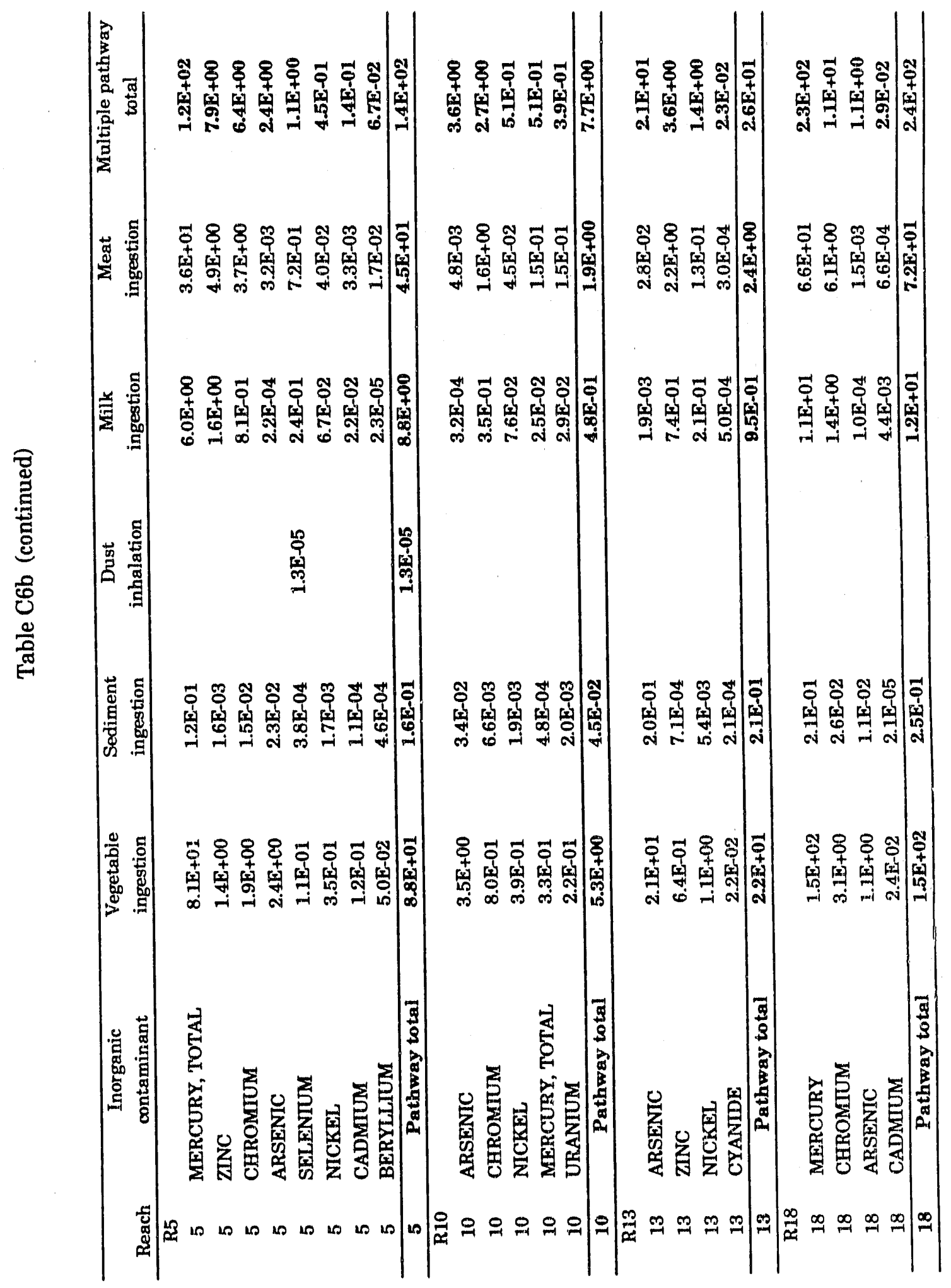



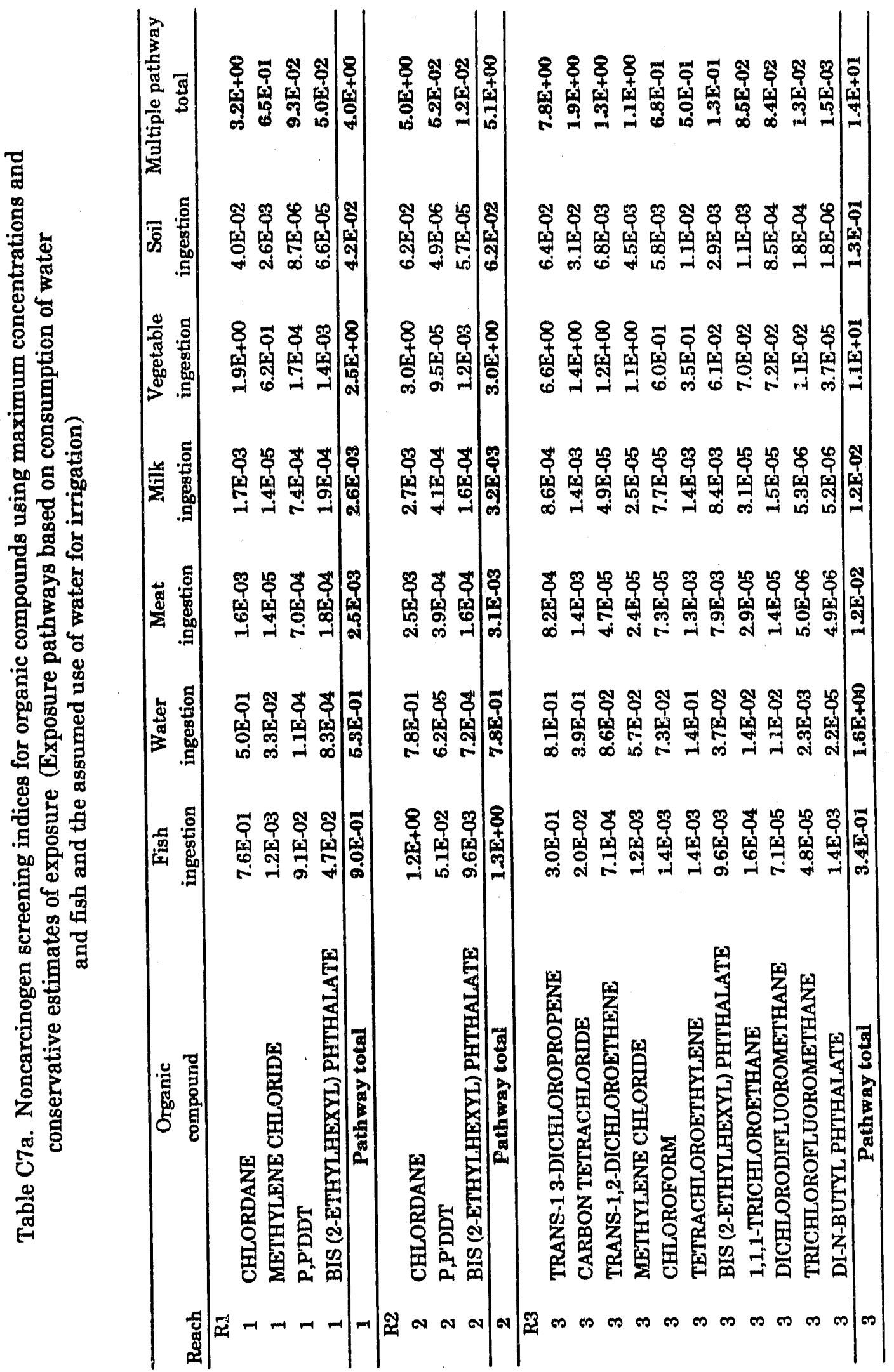


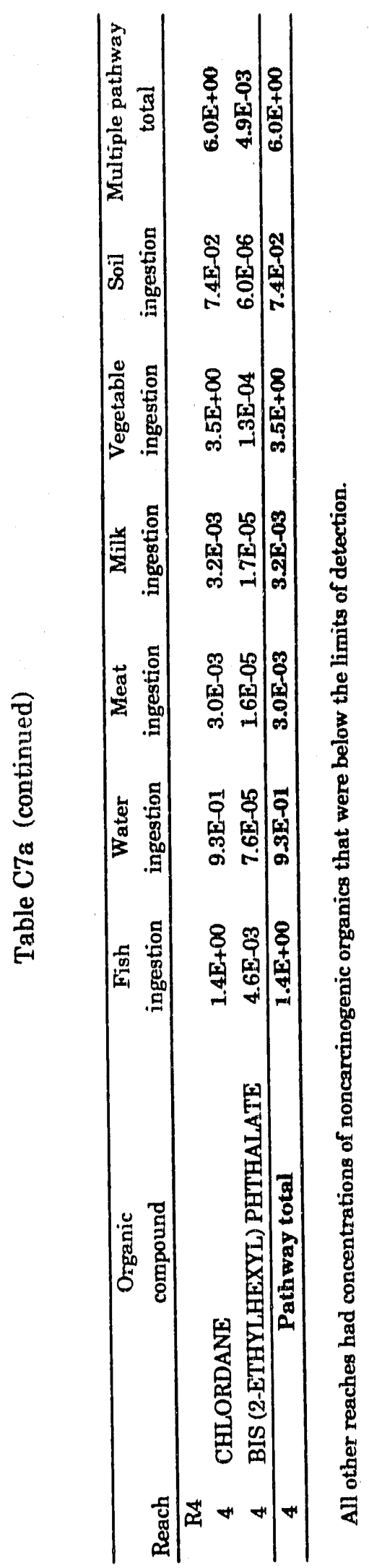



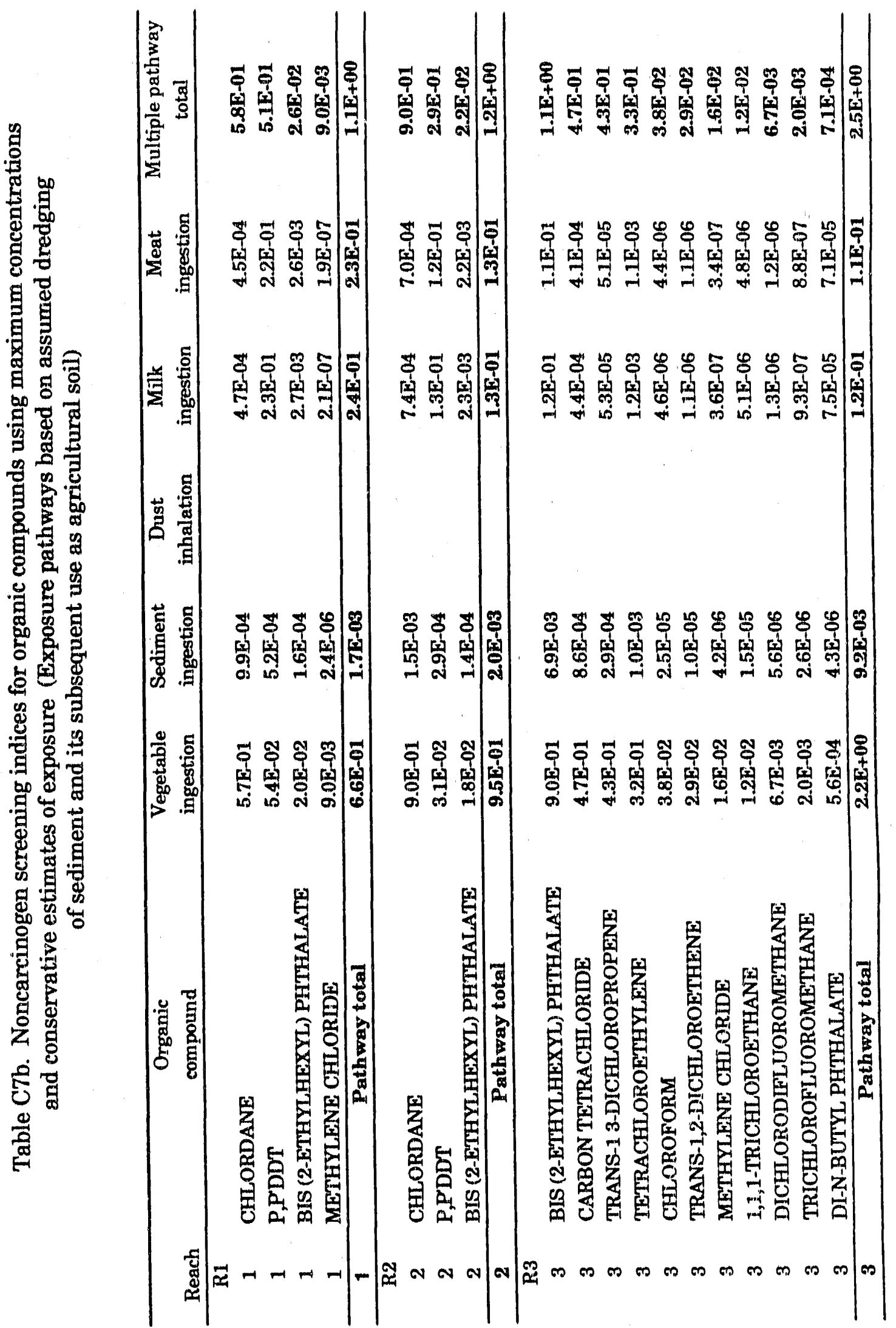


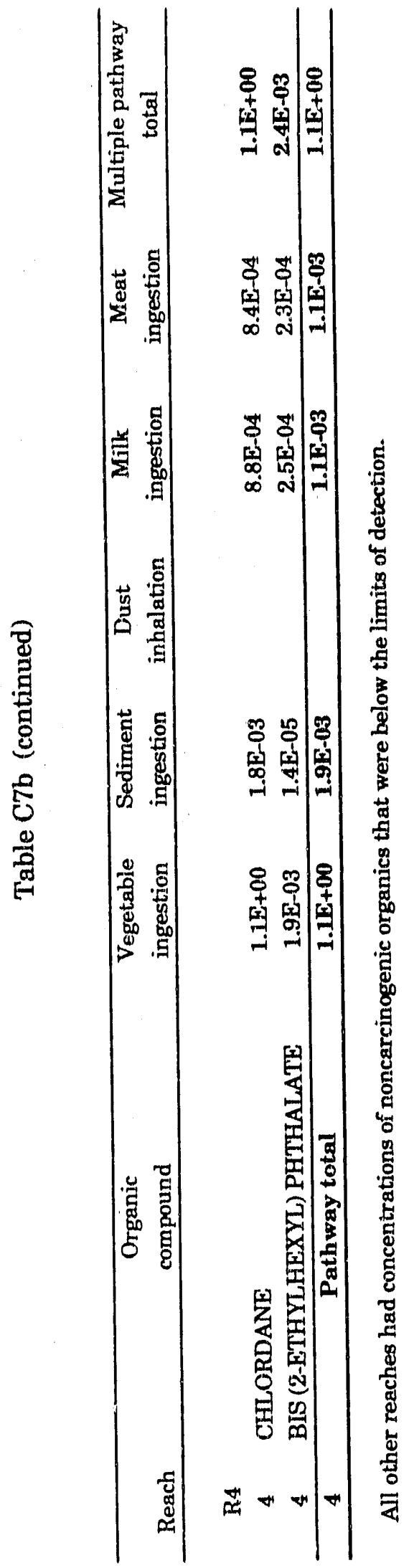


Appendix D

RESULTS OF NONCONSFRVATTVE SCREENING 
Table D1. Summation of screening indices for carcinogens by reach, exposure pathway, and contaminant type using mean

concentrations and nonconservative

estimates of exposure

\begin{tabular}{|c|c|c|c|c|c|}
\hline Reach & $\begin{array}{c}\text { Contaminant } \\
\text { type }\end{array}$ & $\begin{array}{l}\text { Sediment } \\
\text { ingeation }\end{array}$ & $\begin{array}{c}\text { Flsh } \\
\text { ingestion }\end{array}$ & $\begin{array}{c}\text { Water } \\
\text { ingestion }\end{array}$ & $\begin{array}{l}\text { Sediment } \\
\text { external }\end{array}$ \\
\hline $\mathrm{R} 1$ & Inorganics & $4.6 \mathrm{E}-06$ & $1.2 \mathrm{E}-05$ & $1.3 \mathrm{E}-03$ & \\
\hline $\mathrm{R} 1$ & Organics & $9.8 \mathrm{E}-07$ & $1.4 \mathrm{E}-04$ & & \\
\hline $\mathrm{R} 1$ & Radionuclides & $3.3 \mathrm{E}-07$ & $1.4 \mathrm{E}-07$ & $2.0 \mathrm{E} \sim 06$ & $5.0 \mathrm{E}-05$ \\
\hline $\mathbf{R 1}$ & Pathway total & 5.9E-06 & $1.5 F_{1}-04$ & $1.3 \mathrm{E}-03$ & $5.0 \mathrm{E}-05$ \\
\hline $\mathrm{R} 2$ & Inorganics & 2.2E-06 & $2.2 \mathrm{E}-05$ & $1.4 \mathrm{E}-04$ & \\
\hline $\mathrm{R} 2$ & Organics & $3.1 \mathrm{E}-06$ & $3.5 \mathrm{E}-04$ & & \\
\hline $\mathrm{R} 2$ & Radionuclides & $5.8 \mathrm{E}-06$ & $2.3 \mathrm{E}-06$ & 1.3E-04 & 1.3E-03 \\
\hline $\bar{R} 2$ & Pathway total & $1.1 \mathrm{E}-05$ & 3.7E-04 & $2.8 \mathrm{E}-04$ & $1.3 \mathrm{E}-03$ \\
\hline $\mathrm{R} 3$ & Inorganica & $5.8 \mathrm{E}-06$ & $2.1 \mathrm{E}-05$ & $6.8 \mathrm{E}-05$ & \\
\hline R3 & Organics & $5.6 \mathrm{E}-06$ & $6.1 \mathrm{E}-04$ & $9.2 \mathrm{E}-05$ & \\
\hline $\mathrm{R3}$ & Radionuclides & $1.0 \mathrm{E}-06$ & $2.7 \mathrm{E}-08$ & & $1.6 \mathrm{E}-04$ \\
\hline R3 & Pathway total & $1.2 \mathrm{E} \cdot 05$ & $6.3 \mathrm{E}-04$ & $1.6 \mathrm{E}-04$ & $1.6 \mathrm{E} \cdot 04$ \\
\hline $\mathrm{R} 4$ & Inorganics & 3.5E-06 & $1.3 \mathrm{E}-05$ & $3.1 \mathrm{E}-05$ & \\
\hline $\mathrm{R} 4$ & Organics & & $2.5 \mathrm{E}-04$ & & \\
\hline $\mathrm{RA}$ & Radionuclides & 5.3E-07 & 5.3E-07 & 2.1E-06 & $1.2 \mathrm{E}-04$ \\
\hline $\mathbf{R 4}$ & Pathway total & $4.0 \mathrm{E}-06$ & 2.7E-04 & 3.3E-05 & $1.2 \mathrm{E}-04$ \\
\hline R5 & Inorganics & $5.0 \mathrm{E}-06$ & $1.5 \mathrm{E}-05$ & & \\
\hline R5 & Organics & & $5.0 \mathrm{E}-04$ & & \\
\hline RE & Radionuclides & $3.2 \mathrm{E}-08$ & & & $1.5 \mathrm{E}-05$ \\
\hline $\mathbf{R 5}$ & Pathway total & $5.0 \mathrm{E}-06$ & 5.1E-04 & & $1.5 \mathrm{E} \cdot 05$ \\
\hline R10 & Inorganics & $5.0 \mathrm{E}-06$ & & & \\
\hline $\mathrm{R} 10$ & Radionuclides & $1.9 \mathrm{E}-08$ & & & $6.0 \mathrm{E}-06$ \\
\hline $\mathbf{R 1 0}$ & Pathway total & $5.0 \mathrm{E} \cdot 06$ & & & $6.0 \mathrm{E}-06$ \\
\hline $\mathrm{R} 13$ & Inorganics & & & $3.4 \mathrm{E}-05$ & \\
\hline R13 & Pathway total & & & 3.4E-05 & \\
\hline $\mathrm{R} 18$ & Inorganics & & $1.5 \mathrm{E}-05$ & & \\
\hline R18 & Organics & & $1.4 \mathrm{E}-04$ & & \\
\hline R18 & Radionuclides & $1.8 \mathrm{E}-09$ & & & $1.3 \mathrm{E}-06$ \\
\hline R18 & Pathway total & $1.8 \mathrm{E}-09$ & $1.6 \mathrm{E}-04$ & & $1.3 \mathrm{E}-06$ \\
\hline
\end{tabular}


Table D2. Summation of screening indices for noncarcinogens by reach, exposure pathway, and contaminant type using mean concentrations and nonconservative estimates of exposure

\begin{tabular}{|c|c|c|c|c|}
\hline Reach & $\begin{array}{c}\text { Contaminant } \\
\text { type }\end{array}$ & $\begin{array}{l}\text { Sediment } \\
\text { ingestion }\end{array}$ & $\begin{array}{c}\text { Fish } \\
\text { ingestion }\end{array}$ & $\begin{array}{c}\text { Water } \\
\text { ingestion }\end{array}$ \\
\hline R1 & Inorganics & $3.5 \mathrm{E}-03$ & $1.5 \mathrm{E}+00$ & $7.7 \mathrm{E}-01$ \\
\hline R1 & Organics & $1.6 \mathrm{E}-05$ & $1.1 \mathrm{E}-01$ & \\
\hline $\mathbf{R 1}$ & Pathway total & $3.6 \mathrm{E} \cdot 03$ & $1.6 \mathrm{E}+00$ & $7.7 \mathrm{E}-01$ \\
\hline $\mathrm{R} 2$ & Inorganics & $7.7 \mathrm{E}-03$ & $7.5 \mathrm{E}-01$ & $9.3 \mathrm{E}-02$ \\
\hline $\mathrm{R2}$ & Organics & 1.3E-05 & $1.9 \mathrm{E}-01$ & \\
\hline $\mathbf{R 2}$ & Pathway total & $7.7 \mathrm{E}-03$ & $9.4 \mathrm{E}-01$ & 9.3E-02 \\
\hline $\mathrm{R} 3$ & Inorganics & $1.6 \mathrm{E}-02$ & $8.2 \mathrm{E}-01$ & 8.3E-01 \\
\hline R3 & Organics & $6.5 \mathrm{E}-05$ & & $3.0 \mathrm{E}-02$ \\
\hline $\mathbf{R 3}$ & Pathway total & $1.6 \mathrm{E} \cdot 02$ & $8.2 \mathrm{E}-01$ & $8.6 \mathrm{E} \cdot 01$ \\
\hline $\mathrm{R} 4$ & Inorganics & $1.2 \mathrm{E}-02$ & $5.9 \mathrm{E}-02$ & 3.3E-02 \\
\hline R4 & Organics & & $2.1 \mathrm{E}-01$ & \\
\hline $\mathbf{R 4}$ & Pathway total & $1.2 \mathrm{E}-02$ & $2.7 \mathrm{E}-01$ & $3.3 \mathrm{E}-02$ \\
\hline R5 & Inorganics & $4.1 \mathrm{E}-03$ & 3.0E-02 & \\
\hline $\mathbf{R 5}$ & Pathway total & $4.1 \mathrm{E}-03$ & $3.0 \mathrm{E}-02$ & \\
\hline R10 & Inorganics & $3.9 \mathrm{E}-03$ & & \\
\hline R10 & Pathway total & 3.9E-03 & & \\
\hline R13 & Inorganics & & & 3.7E-02 \\
\hline R13 & Pathway total & & & 3.7E-02 \\
\hline $\mathrm{R} 18$ & Inorganics & & 4.1E-02 & \\
\hline R18 & Pathway total & & $4.1 \mathrm{E}-02$ & \\
\hline
\end{tabular}


Table D3. Carcinogen screening indices for inorganics by reach and pathway using mean concentrations with nonconservative estimates of exposure

\begin{tabular}{|c|c|c|c|c|}
\hline \multirow[b]{2}{*}{ Reach } & \multirow[b]{2}{*}{$\begin{array}{c}\text { Inorganic } \\
\text { contaminant }\end{array}$} & \multicolumn{3}{|c|}{ Exposure pathways } \\
\hline & & $\begin{array}{l}\text { Sediment } \\
\text { ingestion }\end{array}$ & $\begin{array}{c}\text { Fish } \\
\text { ingestion } \\
\end{array}$ & $\begin{array}{c}\text { Drinking } \\
\text { water }\end{array}$ \\
\hline 1 & ARSENIC & $3.6 \mathrm{E}-06$ & $6.3 \mathrm{E}-06$ & $1.3 \mathrm{E}-03$ \\
\hline 1 & BERYLLIUM & 9.8E-07 & 5.4E-06 & \\
\hline 1 & URANIUIM & $4.7 \mathrm{E}-12$ & & \\
\hline $\mathbf{R 1}$ & Pathway total & $4.6 \mathrm{E}-06$ & $1.2 \mathrm{E}-05$ & $1.3 \mathrm{E}-03$ \\
\hline 2 & ARSENIC & $2.2 \mathrm{E}-06$ & $1.7 \mathrm{E}-05$ & $1.3 \mathrm{E}-04$ \\
\hline 2 & BERYLLIUM & & $4.6 \mathrm{E}-06$ & $1.4 \mathrm{E}-05$ \\
\hline 2 & URANIUM & $1.8 \mathrm{E}-12$ & & \\
\hline $\mathbf{R} 2$ & Pathway total & $2.2 \mathrm{E}-06$ & 2.2E-05 & $1.4 \mathrm{E}-04$ \\
\hline 3 & ARSENIC & 5.8E-06 & $1.7 \mathrm{E}-05$ & 5.3E-05 \\
\hline 3 & BERYLLIUM & & 4.6E-06 & $1.5 \mathrm{E}-05$ \\
\hline 3 & URANIUM & $1.4 \mathrm{E}-11$ & & 4.7E-09 \\
\hline $\mathbf{R 3}$ & Pathway total & $5.8 \mathrm{E} \cdot 06$ & 2.1E-05 & 6.8E-05 \\
\hline 4 & ARSENIC & 2.0E-06 & $1.3 \mathrm{E}-05$ & $3.1 \mathrm{E}-05$ \\
\hline 4 & BERYLLIUM & $1.5 \mathrm{E}-06$ & & \\
\hline 4 & URANIUM & 2.1E-12 & & $4.7 \mathrm{E}-11$ \\
\hline $\mathbf{R 4}$ & Pathway total & $3.5 \mathrm{E}-06$ & $1.3 \mathrm{E}-05$ & 3.1E-05 \\
\hline 5 & ARSENIC & 4.0E-06 & $1.5 \mathrm{E}-05$ & \\
\hline 5 & BERYLLIUM & $9.8 \mathrm{E}-07$ & 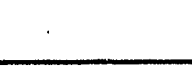 & 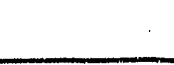 \\
\hline $\mathbf{R 5}$ & Pathway total & 5.0E-06 & $1.5 \mathrm{E}-05$ & \\
\hline 10 & ARSENIC & $5.0 \mathrm{E}-06$ & & \\
\hline 10 & URANIUM & $3.4 \mathrm{E}-12$ & & \\
\hline $\mathbf{R 1 0}$ & Pathway total & 5.0E-06 & & \\
\hline 13 & ARSENIC & & & 3.4E-05 \\
\hline 13 & URANIUM & & & $1.1 \mathrm{E}-10$ \\
\hline $\mathbf{R 1 3}$ & Pathway total & & & $3.4 \mathrm{E} \cdot 05$ \\
\hline 18 & ARSENIC & & $1.5 \mathrm{E}-05$ & \\
\hline R18 & Pathway total & & $1.5 \mathrm{E}-05$ & \\
\hline
\end{tabular}


Table D4. Carcinogen screening indices for organics by reach and pathway using mean concentrations and nonconservative estimates of exposure

\begin{tabular}{|c|c|c|c|c|}
\hline \multirow[b]{2}{*}{ Reach } & \multirow[b]{2}{*}{$\begin{array}{c}\text { Organic } \\
\text { compound }\end{array}$} & \multicolumn{3}{|c|}{ Exposure Pathways } \\
\hline & & $\begin{array}{l}\text { Sediment } \\
\text { ingestion }\end{array}$ & $\begin{array}{c}\text { Fish } \\
\text { ingestion }\end{array}$ & $\begin{array}{c}\text { Drinking } \\
\text { water }\end{array}$ \\
\hline 1 & PCB-1260 (AROCLOR 1260) & & $8.4 \mathrm{E}-05$ & \\
\hline 1 & PCB-1254 (AROCLOR 1254) & & 4.6E-05 & \\
\hline 1 & CHLORDANE & & 8.9E-06 & \\
\hline 1 & $\mathrm{P}, \mathrm{P} \mathrm{DDD}$ & & $1.0 \mathrm{E}-06$ & \\
\hline 1. & FLUORANTHENE & $9.7 \mathrm{E}-07$ & & \\
\hline 1 & BIS (2-ETHYLHEXYL) PHTHALATE & 4.4E-09 & & \\
\hline 1 & METHYLENE CHLORIDE & 1.1.E-10 & & \\
\hline $\mathbf{R 1}$ & Pathway total & 9.8E-07 & $1.4 \mathrm{E} \cdot 04$ & \\
\hline 2 & PCB-1260 (AROCLOR 1260) & $1.8 \mathrm{E}-06$ & $2.1 \mathrm{E}-04$ & \\
\hline 2 & PCB-1254 (AROCLOR 1254) & $1.3 \mathrm{E}-06$ & $1.2 \mathrm{E}-04$ & \\
\hline 2 & CHLORDANE & & $1.4 \mathrm{E}-05$ & \\
\hline 2 & P,P'DDT & & $1.3 \mathrm{E}-06$ & \\
\hline 2 & BIS (2-ETHYLHEXYL) PHTHALATE & 3.5E-09 & & \\
\hline $\mathbf{R 2}$ & Pathway total & 3.1E-06 & 3.5E-04 & \\
\hline 3 & PCB-12Eن (AROCLOR 1260) & & 4.7E-04 & \\
\hline 3 & PCB-1254 (AROCLOR 1254) & & $1.4 \mathrm{E}-04$ & $3.9 \mathrm{E}-05$ \\
\hline 3 & VINYL CHLORIDE & & & $4.9 \mathrm{E}-05$ \\
\hline 3 & CARBON TETRACHLORIDE & & & $2.4 \mathrm{E}-06$ \\
\hline 3 & PYRENE & $1.2 \mathrm{E}-06$ & & \\
\hline 3 & CHRYSENE & $1.2 \mathrm{E}-06$ & & \\
\hline 3 & FLUORANTHENE & $1.1 \mathrm{E}-06$ & & \\
\hline 3 & TRICHLOROETHYLENE & & & $9.8 \mathrm{E}-07$ \\
\hline 3 & PHENANTHRENE & $9.5 \mathrm{E}-07$ & & \\
\hline 3 & TETRACHLOROETHXLENE & & & $9.2 \mathrm{E} \cdots 07$ \\
\hline 3 & BENZO(A)ANTHRACENE & $8.2 \mathrm{E}-07$ & & \\
\hline 3 & ANTHRACENE & 4.0E- 07 & & \\
\hline 3 & BIS (2-ETHYLHEXYL) PHTHALATE & $1.8 \mathrm{E}-08$ & & $3.4 \mathrm{E}-07$ \\
\hline 3 & METHYLENE CHLORIDE & & & $1.4 \mathrm{E}-07$ \\
\hline $\mathbf{R 3}$ & Pathway total & $5.6 \mathrm{E}-06$ & 6.1E-04 & $9.3 \mathrm{E}-05$ \\
\hline 4 & PCB-1254 (AROCLOR 1254) & & $1.2 \mathrm{E}-04$ & \\
\hline 4 & PCB-1260 (AROCLOR 1260) & & $1.2 \mathrm{E}-04$ & \\
\hline 4 & CHLORDANE & & 1.7E-05 & \\
\hline$\overline{\mathrm{RA}}$ & Pathway total & & 2.5E-04 & \\
\hline
\end{tabular}


Table D4 (continued)

\begin{tabular}{|c|c|c|c|c|}
\hline \multirow[b]{2}{*}{ Reach } & \multirow[b]{2}{*}{$\begin{array}{c}\text { Organic } \\
\text { compound }\end{array}$} & \multicolumn{3}{|c|}{ Exposure Pathways } \\
\hline & & $\begin{array}{l}\text { Sediment } \\
\text { ingestion }\end{array}$ & $\begin{array}{c}\text { Fish } \\
\text { ingestion }\end{array}$ & $\begin{array}{c}\text { Drinking } \\
\text { water }\end{array}$ \\
\hline 5 & PCB-1260 (AROCLOR 1260) & & $2.9 \mathrm{E}-04$ & \\
\hline 5 & PCB-1254 (AROCLOR 1254) & & $2.1 \mathrm{E}-04$ & \\
\hline $\mathbf{R 5}$ & Pathway total & & $5.0 \mathrm{E}-04$ & \\
\hline 18 & PCB-1254 (AROCLOR 1254) & & $1.1 \mathrm{E}-04$ & \\
\hline 18 & PCB-1260 (AROCLOR 1260) & & $3.3 \mathrm{E}-05$ & \\
\hline R18 & Pathway total & & $1.4 \mathrm{E}-04$ & \\
\hline
\end{tabular}

All other reaches had concentrations of organics that were below the limits of detection. 
Table D5. Carcinogen screening indices for radionuclides by reach and pathway using mean concentrations and nonconservative estimates of exposure

\begin{tabular}{|c|c|c|c|c|c|}
\hline \multirow[b]{2}{*}{ Reach } & \multirow[b]{2}{*}{ Radionuclide } & \multicolumn{4}{|c|}{ Exposure pathways } \\
\hline & & $\begin{array}{l}\text { Sediment } \\
\text { ingestion }\end{array}$ & $\begin{array}{c}\text { Fish } \\
\text { ingestion }\end{array}$ & $\begin{array}{c}\text { Water } \\
\text { ingestion }\end{array}$ & $\begin{array}{c}\text { Sediment } \\
\text { external }\end{array}$ \\
\hline 1 & $\mathrm{~Pa}-234$ & $6.8 \mathrm{E}-10$ & & & $3.9 \mathrm{E}-05$ \\
\hline 1 & Cs-137 & $7.1 \mathrm{E}-09$ & $6.7 \mathrm{E}-08$ & $4.5 \mathrm{E}-07$ & $5.3 \mathrm{E}-06$ \\
\hline 1 & Co-60 & $8.2 \mathrm{E}-10$ & $6.7 \mathrm{E}-09$ & & $4.4 \mathrm{E}-06$ \\
\hline 1 & Sr-90 & $1.6 \mathrm{E}-09$ & $2.8 \mathrm{E}-08$ & $1.3 \mathrm{E}-06$ & \\
\hline 1 & U-238 & 1.3E-08 & $1.2 \mathrm{E}-08$ & $6.9 \mathrm{E}-08$ & $3.5 \mathrm{E}-07$ \\
\hline 1 & $\mathrm{U}-235$ & 8.1E-09 & 4.4E-09 & $4.8 \mathrm{E}-08$ & $3.7 \mathrm{E}-07$ \\
\hline 1 & Th-232 & $2.8 \mathrm{E}-07$ & & & $4.5 \mathrm{E}-09$ \\
\hline 1 & U-234 & $2.2 \mathrm{E}-08$ & 2.1E-08 & $1.2 \mathrm{E}-07$ & $9.0 \mathrm{E}-09$ \\
\hline 1 & Sr-89 & $2.7 \mathrm{E}-10$ & & & $1.1 \mathrm{E}-07$ \\
\hline 1 & Pu-239 & $9.6 \mathrm{E}-10$ & $1.0 \mathrm{E}-0 \Omega$ & & $5.6 \mathrm{E}-11$ \\
\hline 1 & $\mathrm{Pu}-238$ & $1.2 \mathrm{E}-10$ & $1.9 \mathrm{E}-09$ & & $1.7 \mathrm{E}-11$ \\
\hline 1 & Tc-99 & & $1.5 \mathrm{E}-09$ & & \\
\hline 1 & $\mathrm{U}-236$ & & & $1.2 \mathrm{E}-10$ & \\
\hline 1 & Pathway total & 3.3E-07 & $1.4 \mathrm{E}-07$ & $2.0 \mathrm{E}-06$ & $5.0 \mathrm{E}-05$ \\
\hline 2 & Cs-137 & $1.3 \mathrm{E}-06$ & $1.6 \mathrm{E}-06$ & $8.6 \mathrm{E}-06$ & $9.6 \mathrm{E}-04$ \\
\hline 2 & $\mathrm{Co}-60$ & $3.2 \mathrm{E}-08$ & 3.1E-08 & $9.4 \mathrm{E}-07$ & $1.7 \mathrm{E}-04$ \\
\hline 2 & Sr-90 & $5.9 \mathrm{E}-08$ & $4.0 \mathrm{E}-07$ & $6.8 \mathrm{E}-05$ & \\
\hline 2 & Eu-154 & $8.2 \mathrm{E}-09$ & & & $6.7 \mathrm{E}-05$ \\
\hline 2 & Eu-152 & $5.7 \mathrm{E}-09$ & & & $6.3 \mathrm{E}-05$ \\
\hline 2 & $\mathrm{H}-3$ & & & $5.4 \mathrm{E}-05$ & \\
\hline 2 & $\mathrm{~Pa}-234$ & $4.1 \mathrm{E}-10$ & & & $2.4 \mathrm{E}-05$ \\
\hline 2 & U-238 & 4.3E-07 & $9.3 \mathrm{E}-09$ & $5.2 \mathrm{E}-08$ & $1.2 \mathrm{E}-05$ \\
\hline 2 & $C_{s-134}$ & 8.8E-09 & & & $1.2 \mathrm{E}-05$ \\
\hline 2 & $\mathrm{Am}-241$ & 3.3Е-06 & & $1.7 \mathrm{E}-06$ & $2.9 \mathrm{E}-06$ \\
\hline 2 & $\mathrm{Sr}-89$ & $6.8 \mathrm{E}-09$ & $1.3 \mathrm{E}-07$ & & $2.7 \mathrm{E}-06$ \\
\hline 2 & $\mathrm{Cm} \cdot 244$ & 5.3E-07 & & $1.1 \mathrm{E}-06$ & $2.6 \mathrm{E}-08$ \\
\hline 2 & U-235 & $3.4 \mathrm{E}-08$ & $1.6 \mathrm{E}-09$ & $4.8 \mathrm{E}-08$ & $1.5 \mathrm{E}-06$ \\
\hline 2 & $\mathrm{Pu}-2,39$ & $1.6 \mathrm{E}-08$ & $5.0 \mathrm{E}-08$ & $8.4 \mathrm{E}-08$ & $9.0 \mathrm{E}-10$ \\
\hline 2 & Th-234 & $2.4 \mathrm{E}-09$ & & & $1.1 \mathrm{E}-07$ \\
\hline 2 & U-234 & & $1.7 \mathrm{E}-08$ & $8.2 \mathrm{E}-08$ & \\
\hline 2 & $\mathrm{Pu}-238$ & $1.5 \mathrm{E}-09$ & $1.9 \mathrm{E}-09$ & $3.7 \mathrm{E}-08$ & $2.1 \mathrm{E}-10$ \\
\hline 2 & $\mathrm{U}-236$ & & & $1.4 \mathrm{E}-10$ & \\
\hline 2 & Pathway total & $5.8 \mathrm{E}-06$ & $2.3 \mathrm{E}-06$ & $1.9 \mathrm{E}-04$ & $1.3 \mathrm{E}-03$ \\
\hline
\end{tabular}


Table DE (continued)

\begin{tabular}{|c|c|c|c|c|c|}
\hline \multirow[b]{2}{*}{ Reach } & \multirow[b]{2}{*}{ Radionuclide } & \multicolumn{4}{|c|}{ Exposure pathways } \\
\hline & & $\begin{array}{l}\text { Sediment } \\
\text { ingestion }\end{array}$ & $\begin{array}{c}\text { Fish } \\
\text { ingegtion }\end{array}$ & $\begin{array}{c}\text { Water } \\
\text { ingestion }\end{array}$ & $\begin{array}{c}\text { Sediment } \\
\text { external }\end{array}$ \\
\hline 3 & $\mathrm{~Pa}-234$ & $1.7 \mathrm{E}-09$ & & & $1.0 \mathrm{E}-04$ \\
\hline 3 & U-238 & $8.7 \mathrm{E}-07$ & & & $2.3 \mathrm{E}-05$ \\
\hline 3 & $\mathrm{Co}-60$ & $3.9 \mathrm{E}-09$ & & & $2.1 \mathrm{E}-05$ \\
\hline 3 & Cs-137 & $1.0 \mathrm{E}-08$ & & & 7.5E-06 \\
\hline 3 & U-235 & $8.5 \mathrm{E}-08$ & & & $3.9 \mathrm{E} \cdot 06$ \\
\hline 3 & Cs-134 & $1.0 \mathrm{E}-09$ & & & $1.4 \mathrm{E}-06$ \\
\hline 3 & Th-234 & $7.2 \mathrm{E}-09$ & & & $3.4 \mathrm{E}-07$ \\
\hline 3 & $\mathrm{~Pa}-233$ & $1.3 \mathrm{E}-11$ & & & $5.5 \mathrm{E}-08$ \\
\hline 3 & Sr-90 & $3.6 \mathrm{E}-09$ & $2.3 \mathrm{E}-08$ & & \\
\hline 3 & Am-241 & $9.0 \mathrm{E}-09$ & & & 7.8E-09 \\
\hline 3 & Tc-99 & & $3.5 \mathbb{E}-09$ & & \\
\hline 3 & Pu-239 & 2.1E-09 & & & $1.2 \mathrm{E}-10$ \\
\hline 3 & $\mathrm{Cm}-244$ & $1.2 \mathrm{E}-09$ & & & $5.7 \mathrm{E}-11$ \\
\hline 3 & Pu-238 & $4.6 \mathrm{E}-10$ & & & $6.8 \mathrm{E}-11$ \\
\hline 3 & Pathway total & $1.0 \mathrm{E}-06$ & 2.7 E-08 & & $1.6 \mathrm{E}-04$ \\
\hline 4 & C8-137 & $1.2 \mathrm{E}-07$ & $3.4 \mathrm{E}-07$ & & $8.8 \mathrm{E}-05$ \\
\hline 4 & $\mathrm{Co}-60$ & $3.5 \mathrm{E}-09$ & $8.0 \mathrm{E}-09$ & & $1.9 \mathrm{E}-05$ \\
\hline 4 & U-238 & $2.9 E-07$ & $2.6 \mathrm{E}-08$ & $4.9 \mathrm{E}-08$ & $7.9 \mathrm{E}-06$ \\
\hline 4 & U-2,35 & $3.5 \mathrm{E}-08$ & $6.3 \mathrm{E}-09$ & $4.8 \mathrm{E}-08$ & $1.6 \mathrm{E}-06$ \\
\hline 4 & Sr-90 & $1.4 \mathrm{E}-08$ & 8.9E-08 & $1.6 \mathrm{E}-06$ & \\
\hline 4 & $\mathrm{H}-3$ & & & $3.4 \mathrm{E}-07$ & \\
\hline 4 & $\mathrm{Sr}-89$ & $5.7 \mathrm{E}-10$ & $8.1 \mathrm{E}-09$ & & $2.3 E-07$ \\
\hline 4 & Th-234 & 4.4E-09 & & & $2.1 \mathrm{E}-07$ \\
\hline 4 & U-234 & & $4.8 \mathrm{E}-08$ & $8.2 \mathrm{E}-08$ & \\
\hline 4 & Am-241 & $5.0 \mathrm{E}-08$ & & & $4.4 \mathrm{E}-08$ \\
\hline 4 & $\mathrm{Pu}-239$ & $9.7 E-09$ & $1.6 \mathrm{E}-09$ & & $5.6 \mathrm{E}-10$ \\
\hline 4 & $\mathrm{Cm}-244$ & 5.1E-09 & & & $2.5 \mathrm{E}-10$ \\
\hline 4 & Tc-99 & & $3.8 \mathrm{E}-09$ & & \\
\hline 4 & Pu-238 & $6.9 \mathrm{E}-10$ & $1.4 \mathrm{E}-09$ & & $1.0 \mathrm{E}-10$ \\
\hline 4 & U.236 & & & $2.8 \mathrm{E}-10$ & \\
\hline 4 & Pathway total & $5.9 \mathrm{E}-07$ & $5.3 \mathrm{E}-07$ & 2.1E-06 & $1.2 \mathrm{E}-04$ \\
\hline
\end{tabular}


Table D5 (continued)

\begin{tabular}{|c|c|c|c|c|c|}
\hline \multirow[b]{2}{*}{ Reach } & \multirow[b]{2}{*}{ Radionuclide } & \multicolumn{4}{|c|}{ Exposure pathways } \\
\hline & & $\begin{array}{l}\text { Sediment } \\
\text { ingestion }\end{array}$ & $\begin{array}{c}\text { Fish } \\
\text { ingestion }\end{array}$ & $\begin{array}{c}\text { Water } \\
\text { ingestion }\end{array}$ & $\begin{array}{c}\text { Sediment } \\
\text { external }\end{array}$ \\
\hline 5 & Cs-137 & $1.5 \mathrm{E}-08$ & & & $1.1 \mathrm{E}-05$ \\
\hline 5 & $\mathrm{Co}-60$ & $5.9 \mathrm{E}-10$ & & & $3.1 \mathrm{E}-06$ \\
\hline 5 & Sr-90 & $1.4 \mathrm{E}-08$ & & & \\
\hline 5 & $\mathrm{Pu}-239$ & $2.1 \mathrm{E}-09$ & & & $1.2 \mathrm{E}-1.0$ \\
\hline 5 & Pu-238 & $1.9 \mathrm{E}-10$ & & & $2.7 \mathrm{E}-11$ \\
\hline 5 & Pathway total & $3.2 \mathrm{E}-08$ & & & $1.5 \mathrm{E}-05$ \\
\hline 10 & Cs-137 & $6.2 \mathrm{E}-09$ & & & $4.6 \mathrm{E}-06$ \\
\hline 10 & Sr-89 & 3.4E-09 & & & $1.3 \mathrm{E}-06$ \\
\hline 10 & Am-241 & $4.2 \mathrm{E}-09$ & & & $3.6 \mathrm{E}-09$ \\
\hline 10 & $\mathrm{Sr}-90$ & $4.1 \mathrm{E}-09$ & & & \\
\hline 10 & $\mathrm{Cm}-244$ & $8.4 \mathrm{E}-10$ & & & 4.1E-11 \\
\hline 10 & Pathway total & $1.9 \mathrm{E}-08$ & & & 6.0E-06 \\
\hline 18 & Cs-137 & $1.8 \mathrm{E}-09$ & & & $1.3 \mathrm{E}-06$ \\
\hline 18 & Pathway total & $1.8 \mathrm{E}-09$ & & & $1.3 \mathrm{E}-06$ \\
\hline
\end{tabular}


Table D6. Noncarcinogen screening indices for inorganics by reach and pathway using mean concentrations and nonconservative estimates of exposure

\begin{tabular}{|c|c|c|c|c|}
\hline \multirow[b]{2}{*}{ Reach } & \multirow[b]{2}{*}{$\begin{array}{c}\text { Inorganic } \\
\text { contaminant } \\
\end{array}$} & \multicolumn{3}{|c|}{ Exposure pathways } \\
\hline & & $\begin{array}{l}\text { Sediment } \\
\text { ingestion } \\
\end{array}$ & $\begin{array}{c}\text { Fish } \\
\text { ingestion } \\
\end{array}$ & $\begin{array}{c}\text { Drinking } \\
\text { water }\end{array}$ \\
\hline 1 & THALLIUM & & $1.35 \mathrm{E}+00$ & \\
\hline 1 & ARSENIC & $2.07 \mathrm{E}-03$ & $3.61 \mathrm{E} \cdot 03$ & $7.36 \mathrm{E}-01$ \\
\hline 1 & ANTIMONY & 1.07E-04 & $1.07 \mathrm{E}-01$ & \\
\hline 1 & SELENIUM & 9.52E-05 & $9.65 \mathrm{E}-03$ & $2.38 \mathrm{E}-02$ \\
\hline 1 & MERCURY, TOTAL & $5.00 \mathrm{E}-05$ & $1.26 \mathrm{E}-02$ & \\
\hline 1 & CHROMTUM & $6.29 \mathrm{E}-04$ & $5.60 \mathrm{E}-04$ & $4.29 \mathrm{E}-03$ \\
\hline 1 & SILVER & & $4.16 \mathrm{E}-03$ & \\
\hline 1 & NICKEL & $1.66 \mathrm{E}-04$ & $2.14 \mathrm{E}-03$ & $1.43 \mathrm{E}-03$ \\
\hline 1 & ZINC & $9.64 \mathrm{E}-05$ & $1.56 \mathrm{E}-03$ & $7.14 \mathrm{E}-05$ \\
\hline 1 & BERYLLUUM & $4.57 \mathrm{E}-05$ & $2.51 \mathrm{E}-04$ & \\
\hline 1 & URANIUM & 2.81E-04 & & \\
\hline 1 & CADMIUM & 7.94E-07 & $6.31 \mathrm{E}-06$ & \\
\hline 1 & CYANIDE & $2.86 \mathrm{E}-06$ & & \\
\hline 1 & Pathway total & 3.5E-03 & $1.5 \mathrm{E}+00$ & $7.7 \mathrm{E}-01$ \\
\hline 2 & THALLTUM & & $6.12 \mathrm{E}-01$ & \\
\hline 2 & ANTIMONY & & $1.07 \mathrm{E}-01$ & \\
\hline 2 & ARSENIC & $1.27 \mathrm{E}-03$ & $9.70 \mathrm{E}-03$ & $7.24 \mathrm{E}-02$ \\
\hline 2 & MERCURY, TOTAL & $9.32 \mathrm{E}-04$ & $1.19 \mathrm{E}-02$ & $1.79 \mathrm{E}-03$ \\
\hline 2 & CHROMIUM & $1.48 \mathrm{E}-03$ & $7.71 \mathrm{E}-04$ & $1.07 \mathrm{E}-02$ \\
\hline 2 & NICKEL & $1.29 \mathrm{E}-04$ & 2.14E-03 & $5.01 \mathrm{E}-03$ \\
\hline 2 & SELENIUM & $3.55 \mathrm{E}-03$ & 3.73E-03 & \\
\hline 2 & SILVER & 2.00E-04 & $5.36 \mathrm{E}-03$ & $1.19 \mathrm{E}-03$ \\
\hline 2 & ZINC & $3.75 \mathrm{E}-05$ & $1.57 \mathrm{E}-03$ & $5.72 \mathrm{E}-04$ \\
\hline 2 & CYANIDE & & & $9.82 \mathrm{E}-04$ \\
\hline 2 & BERYLLIUM & & $2.14 \mathrm{E}-04$ & $6.57 \mathrm{E}-04$ \\
\hline 2 & URANIUM & $1.06 \mathrm{E}-04$ & & \\
\hline 2 & CADMIUM & $2.64 \mathrm{E}-06$ & $3.45 \mathrm{E}-06$ & 8.85E-05 \\
\hline 2 & Pathway total & $7.7 \mathrm{E}-03$ & $7.5 \mathrm{E}-01$ & $9.3 \mathrm{E}-02$ \\
\hline
\end{tabular}


Table D6 (continued)

\begin{tabular}{|c|c|c|c|c|}
\hline \multirow[b]{2}{*}{ Reach } & \multirow[b]{2}{*}{$\begin{array}{c}\text { Inorganic } \\
\text { contaminant }\end{array}$} & \multicolumn{3}{|c|}{ Exposure pathways } \\
\hline & & $\begin{array}{l}\text { Sediment } \\
\text { ingestion }\end{array}$ & $\begin{array}{c}\text { Fish } \\
\text { ingestion }\end{array}$ & $\begin{array}{c}\text { Drinking } \\
\text { water }\end{array}$ \\
\hline 3 & THALLIUM & & $6.12 \mathrm{E}-01$ & \\
\hline 3 & ANTIMONY & & $1.07 \mathrm{E}-01$ & $4.64 \mathrm{E}-01$ \\
\hline 3 & URANIUM & $8.46 \mathrm{E}-04$ & & $2.82 \mathrm{E}-01$ \\
\hline 3 & MERCURY, TOTAL & $5.26 \mathrm{E}-03$ & $7.00 \mathrm{E}-02$ & $1.05 \mathrm{E}-04$ \\
\hline 3 & ARSENIC & $3.32 \mathrm{E}-03$ & $9.43 \mathrm{E}-03$ & $3.00 \mathrm{E}-02$ \\
\hline 3 & NICKEL & $8.82 \mathrm{E}-04$ & $3.21 \mathrm{E}-03$ & $1.71 \mathrm{E}-02$ \\
\hline 3 & SILVER & $2.49 \mathrm{E}-04$ & 5.71E-03 & $1.19 \mathrm{E}-02$ \\
\hline 3 & CHROMIUM & $1.31 \mathrm{E}-03$ & $1.39 \mathrm{E}-03$ & $8.45 \mathrm{E}-03$ \\
\hline 3 & SELENIUM & 4.15E-03 & $3.98 \mathrm{E}-03$ & \\
\hline 3 & BORON & & & $7.70 \mathrm{E}-03$ \\
\hline 3 & CYANIDE & & & $3.14 \mathrm{E}-03$ \\
\hline 3 & ZINC & $9.90 \mathrm{E}-05$ & $1.70 \mathrm{E}-03$ & $6.59 \mathrm{E}-04$ \\
\hline 3 & BERYLLIUM & & $2.14 \mathrm{E}-04$ & $7.14 \mathrm{E}-04$ \\
\hline 3 & CADMIUM & $3.10 \mathrm{E}-06$ & $4.73 \mathrm{E}-06$ & $1.15 \mathrm{E} \cdot 04$ \\
\hline 3 & TIN & & & $6.51 \mathrm{E}-05$ \\
\hline 3 & Pathway total & $1.6 \mathrm{E}-02$ & $8.2 E-01$ & 8.3E-01 \\
\hline 4 & MERCURY, TOTAL & $1.41 \mathrm{E}-03$ & $2.68 \mathrm{E}-02$ & $2.38 \mathrm{E}-03$ \\
\hline 4 & ARSENIC & $1.15 \mathrm{E}-03$ & $7.65 \mathrm{E}-03$ & 1.79E-02 \\
\hline 4 & SELENIUM & $5.35 \mathrm{E}-03$ & $1.93 \mathrm{E}-02$ & \\
\hline 4 & NICKEL & $1.32 \mathrm{E}-04$ & $2.14 \mathrm{E}-03$ & $9.02 \mathrm{E}-03$ \\
\hline 4 & URANIUM & $1.27 \mathrm{E}-04$ & & $2.81 \mathrm{E}-03$ \\
\hline 4 & ZINC & $3.84 \mathrm{E}-05$ & $2.22 \mathrm{E}-03$ & $5.49 \mathrm{E}-04$ \\
\hline 4 & VANAJIUIM & $1.88 \mathrm{E}-03$ & & \\
\hline 4 & CHROMIUM & 4.81E-04 & $9.54 \mathrm{E}-04$ & \\
\hline 4 & BARIUM & $1.25 \mathrm{E}-03$ & & \\
\hline 4 & CYANIDE & & & $7.59 \mathrm{E}-04$ \\
\hline 4 & BORON & $2.24 \mathrm{E}-04$ & & \\
\hline 4 & SILVER & $1.21 \mathrm{E}-04$ & & \\
\hline 4 & CADMIUM & $1.51 \mathrm{E}-06$ & $4.09 \mathrm{E}-06$ & $7.94 \mathrm{E}-05$ \\
\hline 4 & BERYLLIUM & $6.89 \mathrm{E}-05$ & & \\
\hline 4 & Pathway total & $1.2 \mathrm{E} \cdot 02$ & 5.9E-02 & $3.3 \mathrm{E}-02$ \\
\hline
\end{tabular}


Table D6 (continued)

\begin{tabular}{|c|c|c|c|c|}
\hline \multirow[b]{2}{*}{ Reach } & \multirow[b]{2}{*}{$\begin{array}{c}\text { Inorganic } \\
\text { contaminant }\end{array}$} & \multicolumn{3}{|c|}{ Exposure pathways } \\
\hline & & $\begin{array}{l}\text { Sediment } \\
\text { ingestion }\end{array}$ & $\begin{array}{c}\text { Fish } \\
\text { ingestion }\end{array}$ & $\begin{array}{c}\text { Drinking } \\
\text { water }\end{array}$ \\
\hline 5 & MERCURY, TOTAL & $3.34 \mathrm{E}-04$ & $1.92 \mathrm{E}-02$ & \\
\hline 5 & ARSENIC & $2.29 \mathrm{E}-03$ & $8.57 \mathrm{E}-03$ & \\
\hline 5 & CHROMIUM & $1.03 \mathrm{E}-03$ & $1.97 \mathrm{E}-03$ & \\
\hline 5 & NICKEL & $1.71 \mathrm{E}-04$ & & \\
\hline 5 & ZINC & $1.57 \mathrm{E}-04$ & & \\
\hline 5 & BERYLLTUM & $4.57 \mathrm{E}-05$ & & \\
\hline 5 & SELENIUM & 3.81E-05 & & \\
\hline 5 & CADMIUM & & $7.14 \mathrm{E}-06$ & \\
\hline $\mathbf{5}$ & Pathway total & $4.1 \mathrm{E}-03$ & 3.0E-02 & \\
\hline 10 & ARSENIC & $2.86 \mathrm{E}-03$ & & \\
\hline 10 & CHROMIUM & $6.29 \mathrm{E}-04$ & & \\
\hline 10 & URANIUM & $2.02 \mathrm{E}-04$ & & \\
\hline 10 & NICKEL & $1.82 \mathrm{E}-04$ & & \\
\hline 10 & MERCURY, TOTAL & $4.76 \mathrm{E}-05$ & & \\
\hline 10 & Pathway total & 8.9Eः03 & & \\
\hline 13 & ARSENIC & & & $1.96 \mathrm{E}-02$ \\
\hline 13 & NICKEL & & & 8.93E-03 \\
\hline 13 & URANIUM & & & $6.79 \mathrm{E}-03$ \\
\hline 13 & CXANIDE & & & $9.82 \mathrm{E}-04$ \\
\hline 13 & ZINC & & & 4.73E-04 \\
\hline 13 & Pathway total & & & 3.7E-02 \\
\hline 18 & MERCURY, TOTAL & & $3.05 \mathrm{E}-02$ & \\
\hline 18 & ARSENIC & & $8.57 \mathrm{E}-03$ & \\
\hline 18 & CHROMIUM & & $1.85 \mathrm{E}-03$ & \\
\hline 18 & CADMIUM & & $2.96 \mathrm{E}-06$ & \\
\hline 18 & Pathway total & & $4.1 \mathrm{E}-02$ & \\
\hline
\end{tabular}


Table D7. Noncarcinogen screening indices for organics by reach and pathway using mean concentrations and nonconservative estimates of exposure

\begin{tabular}{|c|c|c|c|c|}
\hline \multirow[b]{2}{*}{ Roach } & \multirow[b]{2}{*}{$\begin{array}{l}\text { Organio } \\
\text { compound }\end{array}$} & \multicolumn{3}{|c|}{ Exposure Pathways } \\
\hline & & $\begin{array}{l}\text { Sediment } \\
\text { ingestion }\end{array}$ & $\begin{array}{c}\text { Fish } \\
\text { ingestion }\end{array}$ & $\begin{array}{c}\text { Drinking } \\
\text { wator }\end{array}$ \\
\hline 1 & CHLORDANE & & $1.1 \mathrm{E}-01$ & \\
\hline 1 & BIS (2-ETHYLHEXYL) PHTHALATE & $1.6 \mathrm{E}-05$ & & \\
\hline 1 & METHYLENE CHLORIDE & $2.4 \mathrm{E}-07$ & & \\
\hline 1 & Pathway total & $1.6 \mathrm{E} \cdot 05$ & $1.1 \mathrm{E}^{\mathrm{N} 01}$ & \\
\hline 2 & CHLORDANE & & $1.8 \mathrm{E}-01$ & \\
\hline 2 & P,P'DDT & & $7.7 \mathrm{E}-03$ & \\
\hline 2 & BIS (2-ETHYLHEXYL) PHTHALATE & $1.3 \mathrm{E}-05$ & & \\
\hline 2 & Pathway total & $1.3 \mathrm{E} \cdot 05$ & $1.9 \mathrm{E}-01$ & \\
\hline 3 & CARBON TETRACHLORIDE & & & $2.6 \mathrm{E}-02$ \\
\hline 3 & TETRACHLOROETHYLENE & & & $1.8 \mathrm{E}-03$ \\
\hline 3 & BIS (2-ETHYLHEXYL) PHTHALATE & $6.5 \mathrm{E}-05$ & & $1.2 \mathrm{E}-03$ \\
\hline 3 & METHYLENE CHLORIDE & & & $3.2 \mathrm{E}-04$ \\
\hline 3 & 1,1,1-TRICHLOROETHANE & & & $2.0 \mathrm{E}-04$ \\
\hline 3 & DICHLORODIFLUOROMETHANE & & & $1.9 \mathrm{E}-04$ \\
\hline 3 & TRICHLOROFLUOROMETHIANE & & & $5.6 \mathrm{E}-05$ \\
\hline 3 & DI-N-BUTYL PHTHALATE & $1,9 \mathrm{E}-07$ & & \\
\hline 3 & Pathway total & $6.5 \mathrm{E} \cdot 05$ & & $3.0 \mathrm{E} \cdot 02$ \\
\hline 4 & CHLORDANE & & $2.1 \mathrm{E}-01$ & \\
\hline 4 & Pathway total & & $2.1 \mathrm{E} \cdot 01$ & \\
\hline
\end{tabular}

All other reaches had concentrations of organics that were below the limits of detection. 
Appendix E

RESULTS OF NONCONSERVATTVE SCREENING FOR THE LOWEST REPORTED LESS-THAN-DETECTABLE QUANTTTIES OF CONTAMINANTS 
Table E1. Lowest limits of detection reported in the data base for inorganic compounds

\begin{tabular}{lccc}
\hline $\begin{array}{c}\text { Inorganic } \\
\text { chemical }\end{array}$ & $\begin{array}{c}\text { Sediment } \\
(\mathrm{mg} / \mathrm{kg}, \mathrm{dry})\end{array}$ & $\begin{array}{c}\text { Fish } \\
(\mathrm{mg} / \mathrm{kg}, \text { wet })\end{array}$ & $\begin{array}{c}\text { Water } \\
(\mathrm{mg} / \mathrm{L})\end{array}$ \\
\hline ALUMINUM & & & $1.0 \mathrm{E}-02$ \\
ANTIMONY & & $1.0 \mathrm{E}+00$ & $5.0 \mathrm{E}-02$ \\
ARSENIO & $5.0 \mathrm{E}+00$ & $2.0 \mathrm{E}-02$ & $1.0 \mathrm{E}-03$ \\
BARIUM & & & $1.0 \mathrm{E}-01$ \\
BERYLLIUM & & $2.0 \mathrm{E}-02$ & $5.0 \mathrm{E}-04$ \\
BORON & & & $4.0 \mathrm{E}-03$ \\
CADMIUM & $3.0 \mathrm{E}-01$ & $2.0 \mathrm{E}-03$ & $1.0 \mathrm{E}-03$ \\
CHROMIUM & & $2.0 \mathrm{E}-02$ & $1.0 \mathrm{E}-02$ \\
COPPER & $4.0 \mathrm{E}-01$ & $1.0 \mathrm{E}-01$ & $2.0 \mathrm{E}-03$ \\
CYANIDE & $7.0 \mathrm{E}-01$ & & $2.0 \mathrm{E}-03$ \\
LEAD & $5.0 \mathrm{E}+00$ & $2.0 \mathrm{E}-02$ & $1.0 \mathrm{E}-03$ \\
LITHIUM & & & $1.0 \mathrm{E}-03$ \\
MERCURY & $1.0 \mathrm{E}-01$ & $1.0 \mathrm{E}-01$ & $5.0 \mathrm{E}-05$ \\
MOLYBDENUM & & & $1.0 \mathrm{E}-02$ \\
INICKEL & & $1.0 \mathrm{E}+00$ & $1.0 \mathrm{E}-03$ \\
NIOBIUM & & & $7.0 \mathrm{E}-03$ \\
SELENIUM & & $2.0 \mathrm{E}-02$ & $1.0 \mathrm{E}-03$ \\
SILVER & & $2.0 \mathrm{E}-01$ & $1.0 \mathrm{E}-03$ \\
THALLIUM & $6.0 \mathrm{E}+00$ & $1.0 \mathrm{E}+00$ & $1.0 \mathrm{E}-02$ \\
THORIUM & $6.0 \mathrm{E}-01$ & & $2.0 \mathrm{E}-01$ \\
TIN & $5.0 \mathrm{E}+00$ & & $1.0 \mathrm{E}-02$ \\
TITANIUM & $2.0 \mathrm{E}+01$ & & $3.0 \mathrm{E}-03$ \\
URANIUM & & & $1.0 \mathrm{E}-03$ \\
VANADIUM & & & $6.0 \mathrm{E}-03$ \\
ZINC & & & $1.0 \mathrm{E}-03$ \\
ZIRCONIUM & & & $1.0 \mathrm{E}-03$ \\
\hline & & &
\end{tabular}


Table E2. Lowest limits of detection reported in the data base for organic compounds

\begin{tabular}{|c|c|c|c|}
\hline $\begin{array}{l}\text { Organic } \\
\text { compound }\end{array}$ & $\begin{array}{c}\text { Sediment } \\
(\mathrm{mg} / \mathrm{kg}, \mathrm{dry})\end{array}$ & $\begin{array}{c}\text { Fish } \\
(\mathrm{mg} / \mathrm{kg} \text {, wot }) \\
\end{array}$ & $\begin{array}{l}\text { Wutor } \\
(\mathrm{mg} / \mathrm{L})\end{array}$ \\
\hline 1,1,1-TRICHLOROETHANE & $8.0 \mathrm{E}-03$ & $5.0 \mathrm{E} \cdot 02$ & 6.0E-03 \\
\hline 1,1,2,2-TETRACHLOROETHANE & $8.0 \mathrm{E}-03$ & $5.0 \mathrm{E}-02$ & $5.0 \mathrm{E}-03$ \\
\hline 1,1,2-'TRICHLOROETHANE & $8.0 \mathrm{E} \cdot 03$ & 5.0E-02 & \\
\hline 1,1-DICHLOROETHANE & $8.0 \mathrm{E}-03$ & 5.0E-02 & 5.0E-03 \\
\hline 1,1-DICHLOROETHYLENE & $8.0 \mathrm{E} \cdot 03$ & $5.0 \mathrm{E}-02$ & 5.0E-03 \\
\hline 1,2,4-TRICHLOROBENZENE & $5.0 \mathrm{E} \cdot 01$ & 4.1E-01 & $5.0 \mathrm{E}-03$ \\
\hline 1,2,5,6-DIDENZANTHRACENE & $5.0 \mathrm{E}-01$ & $4.1 \mathrm{E}-01$ & 5.0E-03 \\
\hline 1,2-DICHLOROBENZENE & $5.0 \mathrm{E}-01$ & 4.1E-01 & $5.0 \mathrm{E}-03$ \\
\hline 1,2-DICHLOROETHANE & $8.0 \mathrm{E}-03$ & $5.0 \mathrm{E}-02$ & 5.0E-03 \\
\hline 1,2-DICHLOROPROPANE & $8.0 \mathrm{E}-03$ & 5.0E-02 & $6.0 \mathrm{E}=03$ \\
\hline 1,2-DIPHENYLHYDRAZINE & $5.0 \mathrm{E}-01$ & 4.1E-01 & \\
\hline 1,3-DICHLOROBENZENE & 5.0E-01 & 4.1E-01 & 5.0E-03 \\
\hline 1,3-DICHLOROPROPENE & $8.0 \mathrm{E}-03$ & $5.0 \mathrm{E}-02$ & $5.0 \mathrm{E}-03$ \\
\hline 1,4-DICHLOROBENZENE & $5.0 \mathrm{E} \cdot 01$ & 4.1E-01 & 5.0E-03 \\
\hline 2,4,6-TRICHLOROPHENOL & $5.0 \mathrm{E}-01$ & 4.1E-01 & $5.0 \mathrm{E}-03$ \\
\hline 2,4-DICHLOROPHENOL & 5.0E-01 & 4.1E-01 & 5.0E-03 \\
\hline 2,4-DIMETHYLPHENOL & $5.0 \mathrm{E}-01$ & 4.1E-01 & 5.0E-03 \\
\hline 2,4-DINI'TROPHENOL & $5.0 \mathrm{E}+00$ & $4.1 \mathrm{E}+00$ & 5.0E-03 \\
\hline 2,4-DINITROTOLUENE & 5.0E-01 & $4.1 \mathrm{E}-01$ & $5.0 \mathrm{E}-03$ \\
\hline 2,6-DINITROTOLUENE & $5.0 \mathrm{E}-01$ & 4.1E-01 & $5.0 \mathrm{E}-03$ \\
\hline 2.CHLOROETHYL VINYL E'THER & $8.0 \mathrm{E}-03$ & $5.0 \mathrm{E}-02$ & $1.0 \mathrm{E}-02$ \\
\hline 2.CHLORONAPHTHALENE & 5.0E-01 & 4.1E-01 & $5.0 \mathrm{E}-03$ \\
\hline 2.CHLOROPHENOL & $5.0 \mathrm{E}-01$ & 4.1E-01 & 5.0E-03 \\
\hline 2-NITROPHENOL & $5.0 \mathrm{E}-01$ & 4.1E-01 & 5.0E-03 \\
\hline 3,3'-DICHLOROBENZIDINE & $1.6 \mathrm{E}+00$ & $1.0 \mathrm{E}+00$ & $1.0 \mathrm{E}-02$ \\
\hline 4,6-DINITRO-ORTHO-CRESOL & $2.5 \mathrm{E}+00$ & $2.1 E+00$ & $2.5 \mathrm{E}-02$ \\
\hline 4-BROMOPHENYL PHENYL ETHER & 5.0E-01 & 4.1E.01 & $5.0 \mathrm{E}-03$ \\
\hline 4.CHLOROPHENYL PHENXL ETHER & $5.0 \mathrm{E}-01$ & 4.1E-01 & 5.0E-03 \\
\hline 4-NITROPHENOL & $5.0 \mathrm{E}-01$ & 4.11.-01 & $2.5 \mathrm{E}-02$ \\
\hline ACENAPHTHENE & $4.0 \mathrm{E} \sim 03$ & $4.1 \mathrm{E}-01$ & $5.0 \mathrm{E}-03$ \\
\hline ACENAPHTHYLENE & 5.0E-01 & 4.1E-01 & $5.0 \mathrm{E}-03$ \\
\hline ACROLEIN & $8.0 \mathrm{E}-02$ & 5.0E-02 & \\
\hline ACRYLONITRILE & $8.0 \mathrm{E}-02$ & $5.0 \mathrm{E}-02$ & \\
\hline ALDRIN & $5.0 \mathrm{E}-01$ & $1.0 \mathrm{E}-02$ & \\
\hline ALPHA BHC & $5.0 \mathrm{E}-01$ & $1.0 \mathrm{E}-02$ & \\
\hline ANTHRACENE & $2.0 \mathrm{E}-03$ & $4.1 \mathrm{E} \cdot 01$ & 5.0E-03 \\
\hline BENZENE & $8.0 \mathrm{E}-03$ & $5.0 \mathrm{E}-02$ & $5.0 \mathrm{E}-03$ \\
\hline BENZIDINE & $3.2 \mathrm{E}+00$ & $2.1 \mathrm{E}+00$ & 5.0E-03 \\
\hline BENZO(A)ANTHRACENE & $8.0 \mathrm{E}-03$ & $4.1 \mathrm{E}-01$ & 5.0E-03 \\
\hline BENZO(B)FLUORANTHENE & $5.0 \mathrm{E} \cdot 01$ & 4.1E-01 & 5.0E-03 \\
\hline BENZO(GHI)PERYLENE & $5.0 \mathrm{E} \cdot 01$ & 4,1E-01 & 5.0E-03 \\
\hline
\end{tabular}


Table E2 (continued)

\begin{tabular}{|c|c|c|c|}
\hline $\begin{array}{c}\text { Organic } \\
\text { compound }\end{array}$ & $\begin{array}{c}\text { Sediment } \\
(\mathrm{mg} / \mathrm{kg}, \mathrm{dry})\end{array}$ & $\begin{array}{c}\text { Fish } \\
\text { (mg/kg, wet) }\end{array}$ & $\begin{array}{l}\text { Water } \\
(\mathrm{mg} / \mathrm{L})\end{array}$ \\
\hline BENZO(K)FLUORANTHENE & 5.0E-01 & 4.1E-01 & $5.0 \mathrm{E}-03$ \\
\hline BENZO-A-PYRENE & 5.0E-01. & 4.1E-01 & $5.0 \mathrm{E}-03$ \\
\hline BETA BHC & 5.0E-01 & $1.0 \mathrm{E}-02$ & \\
\hline BIS (2-CHLOROETHOXY) METHANE & 5.0E-01 & 4.1E-01 & $5.0 \mathrm{E}-03$ \\
\hline BIS (2-CHLOROETHYL) ETHER & 5.0E-01 & $4.1 \mathrm{E}-01$ & $5.0 \mathrm{E}-03$ \\
\hline BIS (2-CHLOROISOPROPYL) ETHER & $5.0 \mathrm{E}-01$ & 4.1E-01 & 5.0E-03 \\
\hline BIS (2-ETHYLHEXYL) PHTHALATE & 3.0E-03 & $4.1 \mathrm{E}-01$ & 5.0E-03 \\
\hline BIS (CHLOROMETHYL) ETHER & $8.0 \mathrm{E}-03$ & $5.0 \mathrm{E}-02$ & \\
\hline BROMOFORM & $8.0 \mathrm{E}-03$ & $5.0 \mathrm{E}-02$ & $5.0 \mathrm{E}-03$ \\
\hline CARBON TETRACHLORIDE & 8.0E-03 & 5.0E-02 & $5.0 \mathrm{E}-03$ \\
\hline CHLORDANE & $2.5 \mathrm{E}+00$ & $1.0 \mathrm{E}-02$ & \\
\hline CHLOROBENZENE & 8.0E-03 & $5.0 \mathrm{E}-02$ & 5.0E-03 \\
\hline CHLORODIBROMOMETHANE & $8.0 \mathrm{E}-03$ & 5.0E-02 & 5.0E-03 \\
\hline CHLOROETHANE & 8.0E-03 & $5.0 \mathrm{E}-02$ & $1.0 \mathrm{E}-02$ \\
\hline CHLOROFORM & $8.0 \mathrm{E} \cdot 03$ & $5.0 \mathrm{E}-02$ & $5.0 \mathrm{E}-03$ \\
\hline CHRYSENE & 3.0E-03 & 4.1E-01 & $5.0 \mathrm{E}-03$ \\
\hline DELTA BHC & $5.0 \mathrm{E}-01$ & $1.0 \mathrm{E}-02$ & \\
\hline DI-N-BUTYL PHTHALATE & 3.0E-03 & $4.1 \mathrm{E}-01$ & 5.0E-03 \\
\hline DI-N-OCTYL PHTHALATE & 5.0E-01 & 4.1E-01 & 5.0E-03 \\
\hline DICHLOROBROMOMETHANE & $8.0 \mathrm{E}-03$ & $5.0 \mathrm{E}-02$ & 5.0E-03 \\
\hline DICHLORODIFLUOROMETHANE & $8.0 \mathrm{E}-03$ & $5.0 \mathrm{E}-02$ & 5.0E-03 \\
\hline DIELDRIN & 5.0E-01 & $1.0 \mathrm{E}-02$ & \\
\hline DIETHYL PHTHALATE & $6.3 \mathrm{E}-01$ & 4.1E-01 & $5.0 \mathrm{E}-03$ \\
\hline DIMETHYL PHTHALATE & 5.0E-01 & 4.1E-01 & 5.0E-03 \\
\hline ENDOSULFAN SULFATE & $5.0 \mathrm{E}-01$ & $1.0 \mathrm{E}-02$ & \\
\hline ENDOSULFAN, ALPHA & 5.0E-01 & $1.0 \mathrm{E}-02$ & \\
\hline ENDOSULFAN, BETA & 5.0E-01 & $1.0 \mathrm{E}-02$ & \\
\hline ENDRIN & 5.0E-01 & $1.0 \mathrm{E}-02$ & \\
\hline ENDRIN ALDEHYDE & $5.0 \mathrm{E}-01$ & $1.0 \mathrm{E}-02$ & \\
\hline ETHYLBENZCNE & $8.0 \mathrm{E}-03$ & $5.0 \mathrm{E}-02$ & $5.0 \mathrm{E} \cdot 03$ \\
\hline FLUORANTHENE & $2.0 \mathrm{E}-03$ & 4.1E-01 & 5.0E-03 \\
\hline FLUORENE & 5.0E-01 & 4.1E-01 & 5.0E-03 \\
\hline GAMMA BHC & $5.0 \mathrm{E}-01$ & $1.0 \mathrm{E}-02$ & \\
\hline HEPTACHLOR & 5.0E-01 & $1.0 \mathrm{E}-02$ & \\
\hline HEPTACHLOR EPOXIDE & 5.0E-01 & $1.0 \mathrm{E}-02$ & \\
\hline HEXACHLOROBENZENE & 5.0E-01 & 4.1E-01 & 5.0E-03 \\
\hline HEXACHLOROBUTADIENE & 5.0E-01 & 4.1E-01 & $5.0 \mathrm{E}-03$ \\
\hline HEXACHLOROCYCLOPENTADIENE & 5.0E-01 & 4.1E-01 & 5.0E-03 \\
\hline HEXACHLOROETHAINE & $5.0 \mathrm{E} \cdot 01$ & $4.1 \mathrm{E}-01$ & $5.0 \mathrm{E}-03$ \\
\hline INDENO (1,2,3-CD) PYRENE & $5.0 \mathrm{E}-01$ & $4.1 \mathrm{E}-01$ & 5.0E-03 \\
\hline ISOPHORONE & 5.0E-01 & 4.1E-01 & $5.0 \mathrm{E}-03$ \\
\hline
\end{tabular}


Table E2 (continued)

\begin{tabular}{lccc}
\hline $\begin{array}{c}\text { Organic } \\
\text { compound }\end{array}$ & $\begin{array}{c}\text { Sediment } \\
(\mathrm{mg} / \mathrm{kg}, \text { dry })\end{array}$ & $\begin{array}{c}\text { Fish } \\
(\mathrm{mg} / \mathrm{kg} \text {, wet })\end{array}$ & $\begin{array}{c}\text { Water } \\
(\mathrm{mg} / \mathrm{L})\end{array}$ \\
\hline METHYL BROMIDE & & & \\
METHYL CHLORIDE & $8.0 \mathrm{E}-03$ & $5.0 \mathrm{E}-02$ & $1.0 \mathrm{E}-02$ \\
METHYLENE CHLORIDE & $8.0 \mathrm{E}-03$ & $5.0 \mathrm{E}-02$ & $1.0 \mathrm{E}-02$ \\
N-BUTYI, BENZYL PHTHALATE & & $2.5 \mathrm{E}-01$ & $5.0 \mathrm{E}-03$ \\
N-NITROSODI-N-PROPYLAMINE & $5.0 \mathrm{E}-01$ & $4.1 \mathrm{E}-01$ & $5.0 \mathrm{E}-03$ \\
N-NITROSODIMETHYLAMINE & $5.0 \mathrm{E}-01$ & $4.1 \mathrm{E}-01$ & $5.0 \mathrm{E}-03$ \\
N-NITROSODIPHENYLAMINE & $5.0 \mathrm{E}-01$ & $4.1 \mathrm{E}-01$ & $5.0 \mathrm{E}-03$ \\
NAPHTHALENE & $5.0 \mathrm{E}-01$ & $4.1 \mathrm{E}-01$ & $5.0 \mathrm{E}-03$ \\
NITROBENZENE & $5.0 \mathrm{E}-01$ & $4.1 \mathrm{E}-01$ & $5.0 \mathrm{E}-03$ \\
P,P'DDD & $5.0 \mathrm{E}-01$ & $4.1 \mathrm{E}-01$ & $5.0 \mathrm{E}-03$ \\
P,P'DDE & $5.0 \mathrm{E}-01$ & $1.0 \mathrm{E}-02$ & \\
P,P'DDT & $5.0 \mathrm{E}-01$ & $1.0 \mathrm{E}-02$ & \\
PARACHLOROMETA CRESOL & $5.0 \mathrm{E}-01$ & $1.0 \mathrm{E}-02$ & \\
PCB-1254 & $5.0 \mathrm{E}-01$ & $4.1 \mathrm{E}-01$ & $5.0 \mathrm{E}-03$ \\
PCB-1260 & $1.0 \mathrm{E}-01$ & $1.0 \mathrm{E}-02$ & $1.0 \mathrm{E}-03$ \\
PENTACHLOROPHENOL & $1.0 \mathrm{E}-01$ & $1.0 \mathrm{E}-02$ & $1.0 \mathrm{E}-03$ \\
PHENANTHRENE & $5.0 \mathrm{E}-01$ & $4.1 \mathrm{E}-01$ & $2.5 \mathrm{E}-02$ \\
PHENOL & $5.0 \mathrm{E}-03$ & $4.1 \mathrm{E}-01$ & $5.0 \mathrm{E}-03$ \\
PYRENE & $5.0 \mathrm{E}-01$ & $4.1 \mathrm{E}-01$ & $5.0 \mathrm{E}-03$ \\
TETRACHLOROETHYLENE & $2.0 \mathrm{E}-03$ & $4.1 \mathrm{E}-01$ & $5.0 \mathrm{E}-03$ \\
TOLUENE & & $5.0 \mathrm{E}-02$ & $5.0 \mathrm{E}-03$ \\
TOXAPHENE & $8.0 \mathrm{E}-03$ & $5.0 \mathrm{E}-02$ & $5.0 \mathrm{E}-03$ \\
TRANS-1,2-DICHLOROETHENE & $5.0 \mathrm{E}+00$ & $5.0 \mathrm{E}-01$ & \\
TRICHLOROETHYLENE & $8.0 \mathrm{E}-03$ & $5.0 \mathrm{E}-02$ & $5.0 \mathrm{E}-03$ \\
TRICHLOROFLUOROMETHANE & & $5.0 \mathrm{E}-02$ & $5.0 \mathrm{E}-03$ \\
VINYL CHLORIDE & $8.0 \mathrm{E}-03$ & $5.0 \mathrm{E}-02$ & $1.0 \mathrm{E}-03$ \\
& $8.0 \mathrm{E}-03$ & $5.0 \mathrm{E}-02$ & $5.0 \mathrm{E}-03$ \\
\hline
\end{tabular}


133

Table E3. Lowest limits of detection reported in the data base for radionuclides

\begin{tabular}{|c|c|c|c|}
\hline Radionuclide & $\begin{array}{c}\text { Sediment } \\
(\mathrm{Bq} / \mathrm{kg}, \mathrm{dry})\end{array}$ & $\begin{array}{c}\text { Fish } \\
(\mathrm{Bq} / \mathrm{kg}, \text { wet) }\end{array}$ & $\begin{array}{l}\text { Water } \\
(\mathrm{Bq} / \mathrm{L})\end{array}$ \\
\hline Am-241 & & & 1.0E-03 \\
\hline $\mathrm{Cm}-244$ & & & $3.0 \mathrm{E}-03$ \\
\hline Co-60 & $1.5 \mathrm{E}+00$ & & $9.3 \mathrm{E}-02$ \\
\hline Cs -137 & $1.5 \mathrm{E}+00$ & & $9.3 \mathrm{E}-02$ \\
\hline $\mathrm{Pu}-238$ & & & $1.0 \mathrm{E}-03$ \\
\hline $\mathrm{Pu}-239$ & & & $1.0 \mathrm{E}-03$ \\
\hline U-235 & $7.4 \mathrm{E}+00$ & & \\
\hline U-236 & & & $4.4 \mathrm{E}-06$ \\
\hline U-238 & $1.0 \mathrm{E}+02$ & & \\
\hline
\end{tabular}


Table E4. Carcinogen screening indices for inorganics by pathway using lowest limits of detection reported in data base and nonconservative estimates of exposure

\begin{tabular}{lccc}
\hline & \multicolumn{3}{c}{ Exposure pathways } \\
\cline { 2 - 4 } \multicolumn{1}{c}{$\begin{array}{l}\text { Inorganic } \\
\text { compound }\end{array}$} & $\begin{array}{l}\text { Sediment } \\
\text { ingestion }\end{array}$ & $\begin{array}{c}\text { Fish } \\
\text { ingestion }\end{array}$ & $\begin{array}{c}\text { Drinking } \\
\text { water }\end{array}$ \\
\hline & & & \\
BERYLLIUM & & $3.7 \mathrm{E}-06$ & $7.7 \mathrm{E}-06$ \\
ARSENIC & $1.3 \mathrm{E}-06$ & $1.5 \mathrm{E}-06$ & $6.3 \mathrm{E}-06$ \\
URANIUM & $1.6 \mathrm{E}-13$ & & $2.0 \mathrm{E}-11$ \\
& & & $\mathbf{1 . 4 E - 0 5}$ \\
\hline \multicolumn{1}{c}{ Pathway total } & $\mathbf{1 . 3 E - 0 6}$ & 5.2E-06 & \\
\hline
\end{tabular}


Table E5. Carcinogen screening indices for organics by pathway using lowest limits of detection reported in data hase and nonconservative estimates of exposure

\begin{tabular}{|c|c|c|c|}
\hline \multirow[b]{2}{*}{$\begin{array}{l}\text { Organic } \\
\text { compound }\end{array}$} & \multicolumn{3}{|c|}{ Exposure pathways } \\
\hline & $\begin{array}{l}\text { Sediment } \\
\text { ingestion }\end{array}$ & $\begin{array}{c}\text { Fish } \\
\text { ingestion }\end{array}$ & $\begin{array}{c}\text { Drinking } \\
\text { water }\end{array}$ \\
\hline BENZIDINE & $1.1 \mathrm{E}-04$ & $2.1 \mathrm{E}-02$ & 4.1E-03 \\
\hline N-NITROSODIMETHYLAMINE & $3.6 \mathrm{E}-06$ & $9.0 \mathrm{E}-04$ & $9.1 \mathrm{E}-04$ \\
\hline BIS (CHLOROMETHYL) ETHER & 2.5E-07 & $4.7 \mathrm{E}-04$ & \\
\hline ACENAPHTHYLENE & $8.2 \mathrm{E}-07$ & $2.0 \mathrm{E}-04$ & $2.1 \mathrm{E}-04$ \\
\hline BENZO(B)FLUORANTHENE & 8.2E-07 & 2.0E-04 & 2.1E-04 \\
\hline BENZO(GHI)PERYLENE & 8.2E-07 & $2.0 \mathrm{E}-04$ & 2.1E-04 \\
\hline BENZO(K)FLUORANTHENE & 8.2E-07 & $2.0 \mathrm{E}-04$ & $2.1 \mathrm{E}-04$ \\
\hline BENZO-A-PYRENE & $8.2 \mathrm{E}-07$ & 2.0E-04 & 2.1E-04 \\
\hline FLUORENE & 8.2E-07 & $2.0 \mathrm{E}-04$ & $2.1 \mathrm{E}-04$ \\
\hline INDENO (1,2,3-CD) PYRENE & 8.2E-07 & 2.0E-04 & $2.1 \mathrm{E}-04$ \\
\hline ACENAPHTHENE & $6.6 \mathrm{E}-09$ & 2.0E-04 & 2.1E-04 \\
\hline CHRYSENE & $4.9 \mathrm{E}-09$ & $2.0 \mathrm{E}-04$ & 2.1E-04 \\
\hline ANTHRACENE & 3.3E-09 & $2.0 \mathrm{E}-04$ & 2.1E-04 \\
\hline FLUORANTHENE & 3.3E-09 & $2.0 \mathrm{E}-04$ & $2.1 \mathrm{E}-04$ \\
\hline PYRENE & 3.3E-09 & $2.0 \mathrm{E}-04$ & 2.1E-04 \\
\hline 1,2,5,6-DIBENZANTHRACENE & $8.2 \mathrm{E}-07$ & $2.0 \mathrm{E}-04$ & 2.1E-04 \\
\hline BENZO(A)ANTHRACENE & 1.3E-08 & 2.0E-04 & 2.1E-04 \\
\hline PHENANTHRENE & $8.2 \mathrm{E}-09$ & $2.0 \mathrm{E}-04$ & 2.1E-04 \\
\hline N-NITROSODI-N-PROPYLAMINE & 5.0E-07 & $1.2 \mathrm{E}-04$ & $1.3 \mathrm{E}-04$ \\
\hline HEXACHLOROBENZENE & $1.2 \mathrm{E}-07$ & $3.0 \mathrm{E}-05$ & $3.0 \mathrm{E}-05$ \\
\hline VINYL CHLORIDE & $2.6 \mathrm{E}-09$ & $4.9 \mathrm{E}-06$ & 4.1E-05 \\
\hline BIS (2-CHLOROETHYL) ETHER & $7.9 \mathrm{E}-08$ & $1.9 \mathrm{E}-05$ & $2.0 \mathrm{E}-05$ \\
\hline 3,3'-DICHLOROBENZIDINE & $1.0 \mathrm{E}-07$ & $1.9 \mathrm{E}-05$ & $1.6 \mathrm{E}-05$ \\
\hline PCB-1260 & $1.1 \mathrm{E}-07$ & 3.3E-06 & 2.8E-05 \\
\hline TOXAPHENE & $7.9 \mathrm{E}-07$ & $2.4 \mathrm{E}-05$ & \\
\hline 2,4-DINITROTOLUENE & $4.9 \mathrm{E}-08$ & $1.2 \mathrm{E}-05$ & $1.2 \mathrm{E}-05$ \\
\hline 2,6-DINITROTOLUENE & $4.9 \mathrm{E}-08$ & $1.2 \mathrm{E}-05$ & $1.2 \mathrm{E}-05$ \\
\hline 1,2-DIPHENYLHYDRAZINE & $5.7 \mathrm{E}-08$ & $1.4 \mathrm{E}-05$ & \\
\hline 1,1-DICHLOROETHYILENE & $6.9 \mathrm{E}-10$ & 1.3E-06 & $1.1 \mathrm{E}-05$ \\
\hline ALDRIN & $1.2 \mathrm{E}-06$ & 7.3E-06 & \\
\hline DIELDRIN & $1.1 \mathrm{E}-06$ & $6.9 \mathrm{E}-06$ & \\
\hline HEPTACHLOR EPOXIDE & $6.5 \mathrm{E}-07$ & $3.9 \mathrm{E}-06$ & \\
\hline 1,1,2,2-TETRACHLOROETHANE & $2.3 \mathrm{E}-10$ & $4.3 \mathrm{E}-07$ & $3.6 \mathrm{E}-06$ \\
\hline
\end{tabular}


Table E5 (continued)

\begin{tabular}{|c|c|c|c|}
\hline \multirow[b]{2}{*}{$\begin{array}{c}\text { Organic } \\
\text { compound }\end{array}$} & \multicolumn{3}{|c|}{ Exposure pathways } \\
\hline & $\begin{array}{l}\text { Sediment } \\
\text { ingestion }\end{array}$ & $\begin{array}{c}\text { Fish } \\
\text { ingestion } \\
\end{array}$ & $\begin{array}{c}\text { Drinking } \\
\text { water }\end{array}$ \\
\hline 1,3-DICHLOROPROPENE & $2.1 \mathrm{E}-10$ & $3.9 \mathrm{E}-07$ & $3.2 \mathrm{E}-06$ \\
\hline ALPHA BHC & $4.5 \mathrm{E}-07$ & $2.7 \mathrm{E}-06$ & \\
\hline HEXACHLOROBUTADIENE & $5.6 \mathrm{E}-09$ & $1.4 \mathrm{E}-06$ & $1.4 \mathrm{E}-06$ \\
\hline CARBON TETRACHLORIDE & $1.5 \mathrm{E}-10$ & 2.8E-07 & $2.3 \mathrm{E}-06$ \\
\hline DICHLOROBROMOMETHANE & $1.5 \mathrm{E}-10$ & $2.8 \mathrm{E}-07$ & $2.3 \mathrm{E}-06$ \\
\hline HEPTACHLOR & $3.2 \mathrm{E}-07$ & $1.9 \mathrm{E}-06$ & \\
\hline 1,1-DICHLOROETHANE & $1.0 \mathrm{E}-10$ & $2.0 \mathrm{E}-07$ & $1.6 \mathrm{E}-06$ \\
\hline 1,2-DICHLOROETHANE & $1.0 \mathrm{E}-10$ & 2.0E-07 & $1.6 \mathrm{E}-06$ \\
\hline CHLORODIBROMOMETHANE & $9.6 \mathrm{E}-11$ & $1.8 \mathrm{E}-07$ & $1.5 \mathrm{E}-06$ \\
\hline 1,2-DICHLOROPROPANE & $7.8 \mathrm{E}-11$ & $1.5 \mathrm{E}-07$ & $1.2 \mathrm{E}-06$ \\
\hline ACRYLONITRILE & $6.2 \mathrm{E}-09$ & $1.2 \mathrm{E}-06$ & \\
\hline CHLORDANE & $4.6 \mathrm{E}-07$ & $5.6 \mathrm{E}-07$ & \\
\hline TETRACHLOROETHYLENE & & $1.1 \mathrm{E}-07$ & $9.1 \mathrm{E}-07$ \\
\hline BETA BHC & $1.3 \mathrm{E}-07$ & 7.7E-07 & \\
\hline 1,4-DICHLOROBENZENE & $1.7 \mathrm{E}-09$ & $4.2 \mathrm{E}-07$ & 4.3E-07 \\
\hline 2,4,6-TRICHLOROPHENOL & $1.4 \mathrm{E}-09$ & $3.5 \mathrm{E}-07$ & $3.6 \mathrm{E}-07$ \\
\hline BENZENE & 3.3E-11 & $6.2 \mathrm{E}-08$ & $5.2 \mathrm{E}-07$ \\
\hline HEXACHLOROETHANE & $1.0 \mathrm{E}-09$ & $2.5 \mathrm{E}-07$ & $2.5 \mathrm{E}-07$ \\
\hline BIS (2-ETHYLHEXYL) PHTHALATE & $6.0 \mathrm{E}-12$ & $2.5 \mathrm{E}-07$ & $2.5 \mathrm{E}-07$ \\
\hline METHYL CHLORIDE & $1.5 \mathrm{E}-11$ & $2.8 \mathrm{E}-08$ & $4.6 \mathrm{E}-07$ \\
\hline TRICHLOROETHYLENE & & $2.4 \mathrm{E}-08$ & $2.0 \mathrm{E}-07$ \\
\hline METHYLENE CHLORIDE & & $8.0 \mathrm{E}-08$ & $1.3 \mathrm{E}-07$ \\
\hline N-NITROSODIPHENYLAMINE & $3.5 \mathrm{E}-10$ & $8.6 \mathrm{E}-08$ & 8.8E-08 \\
\hline P,P'DDE & $2.4 \mathrm{E}-08$ & $1.5 \mathrm{E}-07$ & \\
\hline P,P'DDT & $2.4 \mathrm{E}-08$ & $1.5 \mathrm{E}-07$ & \\
\hline BROMOFORM & $9.0 \mathrm{E}-12$ & $1.7 \mathrm{E}-08$ & $1.4 \mathrm{E}-07$ \\
\hline ISOPHORONE & $2.9 \mathrm{E}-10$ & $7.2 \mathrm{E}-08$ & $7.3 \mathrm{E}-08$ \\
\hline 1,1,2-TRICHLOROETHANE & $6.5 \mathrm{E}-11$ & $1.2 \mathrm{E}-07$ & \\
\hline CHLOROFORM & $7.0 \mathrm{E}-12$ & $1.3 \mathrm{E}-08$ & $1.1 \mathrm{E}-07$ \\
\hline P,P'DDD & $1.7 \mathrm{E}-08$ & $1.0 \mathrm{E}-07$ & \\
\hline Pathway total & $1.2 \mathrm{E} \cdot 04$ & 2.5E-02 & $8.4 \mathrm{E}-03$ \\
\hline
\end{tabular}


Table E6. Carcinogen screening indices for radionuclides by pathway using lowest limits of detection reported in data base and nonconservative estimates of exposure

\begin{tabular}{|c|c|c|c|c|}
\hline \multirow[b]{2}{*}{ Radionuclide } & \multicolumn{3}{|c|}{ Exposure pathways } & \multirow[b]{2}{*}{$\begin{array}{c}\text { Sediment } \\
\text { external }\end{array}$} \\
\hline & $\begin{array}{l}\text { Sediment } \\
\text { ingestion }\end{array}$ & $\begin{array}{c}\text { Fish } \\
\text { ingestion }\end{array}$ & $\begin{array}{c}\text { Drinking } \\
\text { water }\end{array}$ & \\
\hline U.238 & $2.6 \mathrm{E}-08$ & & & $2.8 \mathrm{E}-06$ \\
\hline $\mathrm{Co}-60$ & $3.9 \mathrm{E}-11$ & & $6.1 \mathrm{E}-08$ & $8.4 \mathrm{E}-07$ \\
\hline U.235 & $1.9 \mathrm{E}-09$ & & & $3.5 \mathrm{E}-07$ \\
\hline Cs-1.37 & 7.3E-11 & & $1.1 \mathrm{E}-07$ & 2.2E-07 \\
\hline $\mathrm{Cm}-244$ & & & $8.6 \mathrm{E}-08$ & \\
\hline Am-241 & & & $5.4 \mathrm{E}-08$ & \\
\hline $\mathrm{Pu}-239$ & & & $1.1 \mathrm{E}-08$ & \\
\hline Pu-238 & & & $9.8 \mathrm{E}-09$ & \\
\hline U.236 & & & $2.9 \mathrm{E}-11$ & \\
\hline Pathway total & $2.8 \mathrm{E}-08$ & & 3.4E-07 & $4.2 \mathrm{E}-06$ \\
\hline
\end{tabular}


Table E7. Noncarcinogen screening indices for inorganics by pathway using lowest limits of detection reported in data base and nonconservative estimates of exposure

\begin{tabular}{lccc}
\hline & \multicolumn{3}{c}{ Exposure pathways } \\
\cline { 2 - 4 } $\begin{array}{l}\text { Inorganic } \\
\text { compound }\end{array}$ & $\begin{array}{c}\text { Sediment } \\
\text { ingestion }\end{array}$ & $\begin{array}{c}\text { Fish } \\
\text { ingestion }\end{array}$ & $\begin{array}{c}\text { Drinking } \\
\text { water }\end{array}$ \\
\hline THORIUM & & & $1.0 \mathrm{E}+01$ \\
THALLIUM & $4.1 \mathrm{E}-02$ & & $5.1 \mathrm{E}-01$ \\
ANTIMONY & $1.0 \mathrm{E}-02$ & $6.1 \mathrm{E}-01$ & $4.5 \mathrm{E}-01$ \\
MERCURY, TOTAL & & $1.1 \mathrm{E}-01$ & $6.0 \mathrm{E}-04$ \\
CHROMIUM & $4.8 \mathrm{E}-05$ & $1.4 \mathrm{E}-02$ & $7.1 \mathrm{E}-03$ \\
BARIUM & & $1.7 \mathrm{E}-04$ & $7.1 \mathrm{E}-03$ \\
ARSENIC & & & $3.6 \mathrm{E}-03$ \\
SILVER & $7.1 \mathrm{E}-04$ & $8.6 \mathrm{E}-04$ & $1.2 \mathrm{E}-03$ \\
VANADIUM & $2.9 \mathrm{E}-05$ & $2.9 \mathrm{E}-03$ & $3.1 \mathrm{E}-03$ \\
NICKEL & & & $1.8 \mathrm{E}-04$ \\
SELENIUM & & $2.1 \mathrm{E}-03$ & $1.2 \mathrm{E}-03$ \\
URANIUM & $2.4 \mathrm{E}-04$ & $2.9 \mathrm{E}-04$ & $1.2 \mathrm{E}-03$ \\
BERYLLIUM & $9.5 \mathrm{E}-06$ & & $3.6 \mathrm{E}-04$ \\
CYANIDE & & & $3.6 \mathrm{E}-04$ \\
BORON & $5.0 \mathrm{E}-06$ & & $1.6 \mathrm{E}-04$ \\
TIN & & & $6.0 \mathrm{E}-05$ \\
CADMIUM & & & $4.0 \mathrm{E}-05$ \\
ZINC & & & $1.8 \mathrm{E}-05$ \\
& & & \\
\hline \multicolumn{1}{c}{ Pathway total } & $5.8 \mathrm{E}-07$ & $9.5 \mathrm{E}-07$ & $1.1 \mathrm{E}+01$ \\
\hline
\end{tabular}


Table E8. Noncarcinogen screening indices for organics by pathway using lowest limits of detection reported in data base and nonconservative estimates of exposure

\begin{tabular}{|c|c|c|c|}
\hline \multirow[b]{2}{*}{$\begin{array}{l}\text { Organic } \\
\text { compound }\end{array}$} & \multicolumn{3}{|c|}{ Exposure pathways } \\
\hline & $\begin{array}{l}\text { Sediment } \\
\text { ingestion }\end{array}$ & $\begin{array}{c}\text { Fish } \\
\text { ingestion }\end{array}$ & $\begin{array}{c}\text { Drinking } \\
\text { water }\end{array}$ \\
\hline 4,6-DINITRO-ORTHO-CRESOL & $3.6 \mathrm{E}-03$ & & $8.9 \mathrm{E}-01$ \\
\hline 2,4-DINITROPHENOL & $3.6 \mathrm{E}-04$ & $8.8 \mathrm{E} \cdot 02$ & $8.9 \mathrm{E}-03$ \\
\hline NITROBENZENE & $1.4 \mathrm{E}-04$ & $3.6 \mathrm{E}-02$ & $3.6 \mathrm{E}-02$ \\
\hline 1,3-DICHLOROPROPENE & $3.8 \mathrm{E}-06$ & 7.1E-03 & $6.0 \mathrm{E}-02$ \\
\hline HEXACHLOROBENZENE & $8.9 \mathrm{E}-05$ & $2.2 \mathrm{E}-02$ & $2.2 \mathrm{E}-02$ \\
\hline HEPTACHLOR EPOXIDE & $5.5 \mathrm{E}-03$ & $3.3 \mathrm{E}-02$ & \\
\hline BENZIDINE & $1.5 \mathrm{E}-04$ & $3.0 \mathrm{E}-02$ & $6.0 \mathrm{E}-03$ \\
\hline HEXACHLOROETHANE & $7.1 \mathrm{E}-05$ & $1.8 \mathrm{E}-02$ & $1.8 \mathrm{E}-02$ \\
\hline CARBON TETRACHLORIDE & $1.6 \mathrm{E}-06$ & $3.1 \mathrm{E}-03$ & $2.6 \mathrm{E}-02$ \\
\hline METHYL BROMIDE & 8.2E-07 & $1.5 \mathrm{E}-03$ & $2.6 \mathrm{E}-02$ \\
\hline HEXACHLOROBUTADIENE & $3.6 \mathrm{E}-05$ & $8.8 \mathrm{E}-03$ & $8.9 \mathrm{E}-03$ \\
\hline ALDRIN & $2.4 \mathrm{E}-03$ & $1.4 \mathrm{E}-02$ & \\
\hline CHLORDANE & $6.0 \mathrm{E}-03$ & $7.1 \mathrm{E}-03$ & \\
\hline 2,4-DICHLOROPHENOL & $2.4 \mathrm{E}-05$ & 5.9E-03 & $6.0 \mathrm{E}-03$ \\
\hline DIELDRIN & $1.4 \mathrm{E}-03$ & 8.6E-03 & \\
\hline ENDOSULFAN, ALPHA & $1.4 \mathrm{E}-03$ & 8.6E-03 & \\
\hline ENDOSULFAN, BETA & $1.4 \mathrm{E}-03$ & $8.6 \mathrm{E}-03$ & \\
\hline 2-CHLOROPHENOL & $1.4 \mathrm{E}-05$ & $3.5 \mathrm{E}-03$ & $3.6 \mathrm{E}-03$ \\
\hline HEXACHLOROCYCLOPENTADIENE & $1.0 \mathrm{E}-05$ & $2.5 \mathrm{E}-03$ & $2.6 \mathrm{E}-03$ \\
\hline PENTACHLOROPHENOL & 2.4E-06 & $5.9 \mathrm{E}-04$ & $3.0 \mathrm{E}-03$ \\
\hline 1,1-DICHLOROETHYLENE & $1.3 \mathrm{E}-07$ & 2.4E-04 & $2.0 \mathrm{E}-03$ \\
\hline CHLOROFORM & $1.1 \mathrm{E}-07$ & 2.1E-04 & $1.8 \mathrm{E}-03$ \\
\hline TETRACHLOROETHYLENE & & 2.1E-04 & $1.8 \mathrm{E}-03$ \\
\hline 1,2,4-TRICHLOROBENZENE & $3.6 \mathrm{E}-06$ & $8.8 \mathrm{E}-04$ & $8.9 \mathrm{E}-\mathrm{C} 4$ \\
\hline BIS (2-ETHYLHEXYL) PHTHALATE & 2.1E-08 & 8.8E-04 & $8.9 \mathrm{E}-04$ \\
\hline ENDRIN & $2.4 \mathrm{E}-04$ & $1.4 \mathrm{E}-03$ & \\
\hline BROMOFORM & 5.7E-08 & 1.1E-04 & $8.9 \mathrm{E}-04$ \\
\hline CHLOROBENZENE & 5.7E-08 & $1.1 \mathrm{E}-04$ & $8.9 \mathrm{E}-04$ \\
\hline CHLORODIBROMOMETHANE & 5.7E-08 & 1.1E-04 & $8.9 \mathrm{E}-04$ \\
\hline DICHLOROBROMOMETHANE & 5.7E-08 & $1.1 \mathrm{E}-04$ & $8.9 \mathrm{E}-04$ \\
\hline TRANS-1,2-DICHLOROETHENE & $5.7 \mathrm{E}-08$ & $1.1 \mathrm{E}-04$ & $8.9 \mathrm{E}-04$ \\
\hline HEPTACHLOR & $1.4 \mathrm{E}-04$ & $8.6 \mathrm{E}-04$ & \\
\hline
\end{tabular}


Table E8 (continued)

\begin{tabular}{|c|c|c|c|}
\hline \multirow[b]{2}{*}{$\begin{array}{l}\text { Organic } \\
\text { compound }\end{array}$} & \multicolumn{3}{|c|}{ Exposure pathways } \\
\hline & $\begin{array}{l}\text { Sediment } \\
\text { ingestion }\end{array}$ & $\begin{array}{c}\text { Fish } \\
\text { ingestion }\end{array}$ & $\begin{array}{c}\text { Drinking } \\
\text { water }\end{array}$ \\
\hline P,P'DDT & $1.4 \mathrm{E}-04$ & $8.6 \mathrm{E} \cdots 04$ & \\
\hline BIS (2-CHLOROISOPROPYL) ETHER & $1.8 \mathrm{E}-06$ & 4.4E-04 & $4.5 \mathrm{E}-04$ \\
\hline 1,1,2-TRICHLOROETHANE & $2.9 \mathrm{E}-07$ & $5.4 \mathrm{E}-04$ & \\
\hline METHYLENE CHLORIDE & & $1.8 \mathrm{E} \cdot 04$ & $3.0 \mathrm{E}-04$ \\
\hline 1,2-DICHLOROBENZENE & $7.9 \mathrm{E}-07$ & $2.0 \mathrm{E}-04$ & $2.0 \mathrm{E}-04$ \\
\hline DI-N-BUTYL PHTHALATE & $4.3 \mathrm{E}-09$ & $1.8 \mathrm{E}-04$ & $1.8 \mathrm{E}-04$ \\
\hline 1,1,1-TRICHLOROETHANE & $1.3 \mathrm{E}-08$ & 2.4E-05 & $2.0 \mathrm{E}-04$ \\
\hline 1,1-DICHLOROETHANE & $1.1 \mathrm{E}-08$ & $2.1 \mathrm{E}-05$ & $1.8 \mathrm{E}-04$ \\
\hline ETHYLBENZENE & $1.1 \mathrm{E}-08$ & $2.1 \mathrm{E}-05$ & $1.8 \mathrm{E}-04$ \\
\hline ISOPHORONE & $3.6 \mathrm{E}-07$ & $8.8 \mathrm{E}-05$ & $8.9 \mathrm{E}-0.5$ \\
\hline N-BUTYL BENZYL PHTHALATE & $3.6 \mathrm{E}-07$ & $8.8 \mathrm{E}-05$ & $8.9 \mathrm{E}-05$ \\
\hline ACROLEIN & $7.1 \mathrm{E}-07$ & $1.3 \mathrm{E}-04$ & \\
\hline DICHLORODIFLUOROMETHANE & 5.7E-09 & $1.1 \mathrm{E}-05$ & $8.9 \mathrm{E}-05$ \\
\hline NAPHTTALENE & $1,8 \mathrm{E}-07$ & 4.4E-05 & $4.5 \mathrm{E}-05$ \\
\hline TOLUENE & $3.8 \mathrm{E}-09$ & $7.1 \mathrm{E}-06$ & $6.0 \mathrm{E}-05$ \\
\hline PHENOL & $1.2 \mathrm{E}-07$ & 2.9E-05 & $3.0 \mathrm{E}-05$ \\
\hline DIETHYL PHTHALATE & $1.1 \mathrm{E}-07$ & $2.2 \mathrm{E}-05$ & $2.2 \mathrm{E}-05$ \\
\hline TRICHLOROFLUOROMETHANE & $3.8 \mathrm{E}-09$ & $7.1 \mathrm{E}-06$ & $1.2 \mathrm{E}-05$ \\
\hline Pathway total & 2.3E-02 & $3.1 \mathrm{E}-01$ & $1.1 \mathrm{E}+00$ \\
\hline
\end{tabular}


Appendix F

COMPARISON OF SCREENING RESULTS USING HEALTH RISK AND ECOLOGICAL END POINTS 


\begin{abstract}
APPENDIX F
One of the Initial tasks of the CRRFI off'-site investigation was to conduct a screening analysis using health risk and ecological screening methodologies to identify contaminants that represent potential risk to human health or the environment. The present report contains the results of the screening analysis using health risk screening end points, and a report by Sutcr (1990) gives the results for screening the same data base using ecological screening risk end points. Ecological end points in the environmental assessment were a $10 \%$ or greater reduction in the abundance or production of the local populations of (1) any fish species, (2) any bird species, or (3) wild mammals species other than small rodents. Other end points were a $10 \%$ reduction in the production of any local plant population and any toxic effect on individuals of an endangered species sulficient to impair survival or reproduction. Except for the endangered species, the end points are effects at the population level of biological organization. A comparison of contaminants assigned a potentially high priority by health risk end points and contaminants assigned a high priority by ecological risk end points is given in Table F1.
\end{abstract}


'Table F1. Comparison of contaminants assigned a potentially high priority through consorvativo screoning by health risk criterin (this study) with those scresned by onvironmontal risk critcria

\begin{tabular}{|c|c|c|c|}
\hline \multirow{2}{*}{ Contaminant } & \multirow[b]{2}{*}{ Reach } & \multicolumn{2}{|c|}{ Screcning End points } \\
\hline & & Health Risk & Environ. Toxicity \\
\hline \multicolumn{4}{|c|}{ Inorganic Chernicals } \\
\hline \multirow[t]{3}{*}{ Aluminum } & 2 & $a$ & $\mathrm{X}$ \\
\hline & 3 & a & $\mathrm{X}$ \\
\hline & 4 & $a$ & $\mathrm{X}$ \\
\hline \multirow[t]{3}{*}{ Antimony } & 1 & $X$ & $\cdots$ \\
\hline & 2 & $X$ & $\cdots$ \\
\hline & 3 & $X$ & $-w$ \\
\hline \multirow[t]{8}{*}{ Arsenic } & 1 & $\mathrm{X}$ & $\ldots$ \\
\hline & 2 & $X$ & $x$ \\
\hline & 3 & $X$ & $X$ \\
\hline & 4 & $X$ & $X$ \\
\hline & 5 & $\mathrm{X}$ & $\cdots$ \\
\hline & 10 & $\mathrm{X}$ & $-\cdots$ \\
\hline & 13 & $\mathrm{X}$ & - \\
\hline & 18 & $\mathrm{X}$ & -- \\
\hline Barium & 4 & $x$ & $\cdots$ \\
\hline \multirow[t]{5}{*}{ Beryllium } & 1 & $X$ & $\cdots$ \\
\hline & 2 & $X$ & $\cdots$ \\
\hline & 3 & $X$ & $\cdots$ \\
\hline & 4 & X & -- \\
\hline & 5 & $\mathrm{X}$ & $-\cdots$ \\
\hline \multirow[t]{2}{*}{ Boron } & 3 & $\mathrm{X}$ & $\mathrm{X}$ \\
\hline & 4 & $X$ & $\cdots$ \\
\hline \multirow[t]{3}{*}{ Cadmium } & 2 & $\mathrm{X}$ & $\mathrm{X}$ \\
\hline & 3 & $X$ & $X$ \\
\hline & 4 & $X$ & $X$ \\
\hline \multirow[t]{3}{*}{ Calcium } & 2 & $b$ & $X$ \\
\hline & 3 & $b$ & $X$ \\
\hline & 4 & $b$ & $X$ \\
\hline
\end{tabular}


Table F1 (continued)

\begin{tabular}{|c|c|c|c|}
\hline \multirow[b]{2}{*}{ Contaminant } & \multirow[b]{2}{*}{ Reach } & \multicolumn{2}{|c|}{ Screening End points } \\
\hline & & Health Risk & Environ. Toxicity \\
\hline \multicolumn{4}{|c|}{ Inorganic Chemicals (continued) } \\
\hline \multirow[t]{7}{*}{ Chromium } & 1 & $\mathrm{x}$ & $\mathrm{x}$ \\
\hline & 2 & $\mathrm{x}$ & $\mathrm{x}$ \\
\hline & 3 & $\mathrm{X}$ & $\mathrm{X}$ \\
\hline & 4 & $\mathrm{X}$ & $\mathrm{X}$ \\
\hline & 5 & $\mathrm{X}$ & - \\
\hline & 10 & $\mathrm{X}$ & -- \\
\hline & 18 & $\mathrm{x}$ & -- \\
\hline \multirow[t]{6}{*}{ Copper } & 1 & $a$ & $\mathrm{x}$ \\
\hline & 2 & $a$ & $\mathrm{X}$ \\
\hline & 3 & $a$ & $\mathrm{x}$ \\
\hline & 4 & $a$ & $\mathrm{x}$ \\
\hline & 5 & $a$ & - \\
\hline & 13 & $a$ & $\mathrm{x}$ \\
\hline Cyanide & 13 & $d$ & $\mathrm{x}$ \\
\hline \multirow[t]{2}{*}{ Lithium } & 1 & $c$ & $\mathrm{x}$ \\
\hline & 3 & c & $\mathrm{x}$ \\
\hline \multirow[t]{7}{*}{ Lead } & 1 & $a$ & - \\
\hline & 2 & $a$ & $\mathrm{x}$ \\
\hline & 3 & a & $\mathrm{X}$ \\
\hline & 4 & $a$ & $\mathrm{x}$ \\
\hline & 5 & $a$ & -- \\
\hline & 10 & $a$ & .. \\
\hline & 13 & $a$ & $\cdots$ \\
\hline Manganese & 5 & $b$ & $\mathrm{x}$ \\
\hline \multirow[t]{8}{*}{ Mercury } & 1 & $\mathrm{X}$ & $\mathrm{x}$ \\
\hline & 2 & e & $\mathrm{x}$ \\
\hline & 3 & $\mathrm{X}$ & $\mathrm{X}$ \\
\hline & 4 & $\mathrm{X}$ & $\mathrm{X}$ \\
\hline & 5 & $\mathrm{X}$ & $\mathrm{X}$ \\
\hline & 10 & $e$ & $\mathrm{X}$ \\
\hline & 13 & $e$ & $\mathrm{X}$ \\
\hline & 18 & $\mathrm{X}$ & $\mathrm{X}$ \\
\hline
\end{tabular}


Table F1 (continued)

\begin{tabular}{|c|c|c|c|}
\hline \multirow[b]{2}{*}{ Contaminant } & \multirow[b]{2}{*}{ Reach } & \multicolumn{2}{|c|}{ Screening End points } \\
\hline & & Health Risk & Environ. Toxicity \\
\hline \multicolumn{4}{|c|}{ Inorganic Chemicals (continued) } \\
\hline \multirow[t]{3}{*}{ Nickel } & 3 & $\mathrm{X}$ & $X$ \\
\hline & 4 & $\mathrm{X}$ & -- \\
\hline & 13 & $\mathrm{X}$ & -- \\
\hline \multirow[t]{5}{*}{ Selenium } & 1 & $\mathrm{X}$ & -- \\
\hline & 2 & $\mathrm{X}$ & -- \\
\hline & 3 & $\mathrm{X}$ & $\mathrm{X}$ \\
\hline & 4 & $\mathrm{X}$ & $\mathrm{X}$ \\
\hline & 5 & $\mathrm{X}$ & - \\
\hline \multirow[t]{3}{*}{ Silver } & 2 & $\mathrm{X}$ & $\mathrm{X}$ \\
\hline & 3 & $\mathrm{X}$ & $\mathrm{X}$ \\
\hline & 4 & $\mathrm{X}$ & $\mathrm{X}$ \\
\hline \multirow[t]{3}{*}{ Thallium } & 1 & $\mathrm{X}$ & $\mathrm{X}$ \\
\hline & 2 & $\mathrm{X}$ & -- \\
\hline & 3 & $\mathrm{X}$ & - \\
\hline \multirow[t]{3}{*}{ Uranium } & 2 & $\mathrm{X}$ & $\mathrm{X}$ \\
\hline & 3 & $\mathrm{X}$ & $\mathrm{X}$ \\
\hline & 4 & e & $\mathrm{X}$ \\
\hline Vanadium & 4 & $\mathrm{X}$ & $\mathrm{X}$ \\
\hline \multirow[t]{6}{*}{ Zinc } & 1 & $\mathrm{X}$ & -- \\
\hline & 2 & $X$ & $X$ \\
\hline & 3 & $X$ & $X$ \\
\hline & 4 & $X$ & $X$ \\
\hline & 5 & $X$ & -- \\
\hline & 13 & $X$ & -- \\
\hline
\end{tabular}


Table F1 (continued)

\begin{tabular}{|c|c|c|c|}
\hline \multirow[b]{2}{*}{ Contaminant } & \multirow[b]{2}{*}{ Reach } & \multicolumn{2}{|c|}{ Screening End points } \\
\hline & & Health Risk & Environ. Toxicity \\
\hline \multicolumn{4}{|l|}{ Organic Chemicals } \\
\hline \multirow[t]{3}{*}{ Chlordane } & 1 & $\mathrm{X}$ & -. \\
\hline & 2 & $\mathrm{X}$ & -- \\
\hline & 4 & $\mathrm{X}$ & -- \\
\hline \multirow[t]{6}{*}{ PCB-1254 } & 1 & $\mathrm{X}$ & $\mathrm{X}$ \\
\hline & 2 & $\mathrm{X}$ & $\mathrm{X}$ \\
\hline & 3 & $\mathrm{X}$ & $\mathrm{X}$ \\
\hline & 4 & $\mathrm{X}$ & $\mathrm{X}$ \\
\hline & 5 & $\mathrm{X}$ & $\mathrm{X}$ \\
\hline & 18 & $\mathrm{X}$ & $\mathrm{X}$ \\
\hline \multirow[t]{5}{*}{ PCB-1260 } & 1 & $\mathrm{X}$ & $\mathrm{X}$ \\
\hline & 2 & $\mathrm{X}$ & $\mathrm{X}$ \\
\hline & 3 & $\mathrm{X}$ & $\mathrm{X}$ \\
\hline & 4 & $\mathrm{X}$ & $\mathrm{X}$ \\
\hline & 5 & $\mathrm{X}$ & $\mathrm{X}$ \\
\hline Vinyl Chloride & 3 & $\mathrm{X}$ & - \\
\hline \multirow[t]{2}{*}{ Anthracene } & 3 & $\mathrm{X}$ & -. \\
\hline & 4 & $\mathrm{X}$ & - \\
\hline \multicolumn{4}{|l|}{ Benzo(A)anthracene } \\
\hline & 3 & $\mathrm{X}$ & -- \\
\hline & 4 & $\mathrm{X}$ & $\cdots$ \\
\hline \multirow[t]{2}{*}{ Chrysene } & 3 & $\mathrm{X}$ & $\cdots$ \\
\hline & 4 & $\mathrm{X}$ & - \\
\hline \multirow[t]{2}{*}{ DDT } & 1 & $e$ & $\mathrm{X}$ \\
\hline & 2 & $\mathfrak{c}^{\mathfrak{*}}$ & $\mathrm{X}$ \\
\hline \multirow[t]{2}{*}{ Fluoranthene } & 1 & $\mathrm{X}$ & -. \\
\hline & 3 & $X$ & - \\
\hline Methylene chloride & 3 & $\mathrm{X}$ & -- \\
\hline
\end{tabular}


Table F1 (continued)

\begin{tabular}{|c|c|c|c|}
\hline & & Screeni & ind points \\
\hline Contaminant & ach & Health Risk & Environ. Toxicity \\
\hline Organic Chemicals (cont & nued) & & \\
\hline Phenanthrene & 3 & $X$ & -- \\
\hline & 4 & $X$ & -- \\
\hline Pyrene & 3 & $X$ & - \\
\hline & 4 & $\mathrm{X}$ & -- \\
\hline trans-1,3-Dichloropropen & & & \\
\hline & 3 & $\mathrm{X}$ & $-\cdots$ \\
\hline Carbon Tetrachloride & 3 & $\mathrm{X}$ & $-\cdot$ \\
\hline trans-1,2-Dichloroethane & & & \\
\hline & 3 & $\mathrm{X}$ & -- \\
\hline Bis(2-ethylhexyl)phthalat & & & \\
\hline & 3 & $\mathrm{X}$ & $\mathrm{X}$ \\
\hline 4-6-Dinitro-ortho-cresol & 1 & $\mathrm{X}$ & -- \\
\hline & 3 & $\mathrm{X}$ & $\cdots$ \\
\hline Radionuclides & & & \\
\hline $\operatorname{Sr}-90$ & 2 & $\mathrm{X}$ & -- \\
\hline & 4 & $\mathrm{X}$ & -- \\
\hline Cs- 137 & 2 & $\mathrm{X}$ & -- \\
\hline & 4 & $\mathrm{X}$ & -- \\
\hline & 5 & $X$ & -- \\
\hline $\mathrm{H}-3$ & 2 & $\mathrm{X}$ & -- \\
\hline Co-60 & 2 & $\mathrm{X}$ & -- \\
\hline & 3 & $X$ & -- \\
\hline & 4 & $X$ & -- \\
\hline & 5 & $X$ & -- \\
\hline Eu-152 & 2 & $\mathrm{X}$ & -- \\
\hline Eu-154 & 2 & $x$ & -- \\
\hline
\end{tabular}


Table F1 (continued)

\begin{tabular}{|c|c|c|c|}
\hline \multirow[b]{2}{*}{ Contaminant } & \multirow[b]{2}{*}{ Reach } & \multicolumn{2}{|c|}{ Screening End points } \\
\hline & & Health Risk & Environ. Toxicity \\
\hline \multicolumn{4}{|c|}{ Radionuclides (continued) } \\
\hline Am-241 & 2 & $\mathrm{X}$ & -- \\
\hline & 4 & $\mathrm{X}$ & -... \\
\hline Pu-239 & 2 & $\mathrm{X}$ & -- \\
\hline $\mathrm{Pa}-234$ & 3 & $\mathrm{X}$ & $\cdots$ \\
\hline $\mathrm{Cm}-244$ & 2 & $\mathrm{X}$ & $\cdots$ \\
\hline U-238 & $\begin{array}{l}2 \\
2\end{array}$ & $\begin{array}{l}X \\
Y\end{array}$ & -- \\
\hline & 3 & $\begin{array}{l}X \\
Y\end{array}$ & -- \\
\hline & 4 & $x$ & $\cdots$ \\
\hline
\end{tabular}

${ }^{a}$ Contaminants for which health screening indices were not estimated because EPA reference dose factors and cancer slope factors w/ere not available.

${ }^{b}$ Essential element not considered for helalth risk screening.

${ }^{c}$ Contaminant not listed in data base used for health risk screening.

${ }^{d}$ Designated as a definitely low priority contaminant for health risk screening.

${ }^{e}$ Designated as a contaminant of concern but not given a high priority.

Source: Suter 1990. 
ORNL/ER-9

\section{INTERNAL DISTRIBUTION}

1. S. M. Adams, 1505, MS6036

2. L. W. Barnthouse, 1505 , MS6036

3. S. M. Bartell, 1505, MS6036

4. L. D. Bates, K1330, MS7298

5-8. B. G. Blaylock, 1505, MS6036

9. G. E. Butterworth, 1037, MS7357

10. T. R. Butz, 9116, MS8098

11. K. W. Cook, 3001, MS6029

12. R. B. Cook, 1505, MS6036

13. K. F. Eckerman, 7509, MS6383

14. E. L. Etnier, 2001, MS6050

15. C. J. Ford, 1504, MS6351

16-20. M. L. Frank, 1505, MS6036

21. C. W. Gehrs, 1505 , MS6036

22. M. Gentry, 1505 , MS6038

23. C. D. Goins, K1330, MS7298

24. J. L. Haymore, K1310H, MS7256

25. S. G. Hildebrand, 1505 , MS6036

26-30. F. O. Hoffman, 1505, MS6036

31. L. A. Hook, 1505, MS6038

32. D. D. Huff, 1505 , MS6036

33-37. B. L. Kimmel, 1505, MS6038

38. T. M. Koepp, K1310E, MS7222

39. D. C. Kocher, 7509, MS6383

40. I. L. Larsen, 1505, MS6036

41. J. M. Loar, 1505, MS6036

42. L. W. Long, 1001, MS7155

43. P.-Y. Lu, 2001, MS6050
44. A. P. Malinauskas, 4500 S, MS6135

45. L. W. McMahon, 9704-1, MS8060

46. L. E. McNeese, 3047 , MS6023

47. M. E. Mitchell, 1001, MS7155

48. C. E. Nix, 4500S, MS6102

49. T. P. Perry, 1001, MS7155

50. D. E. Reichle, $4500 \mathrm{~N}, \mathrm{MS} 6253$

51. T. H. Row, 4500 N, MS6198

52. M. J. Sale, 1505, MS6036

53. G. R. Southworth, 1505, MS6036

54. C. L. Stair, K1001, MS7155

55. J. E. Stone, 9704-1, MS8060

56. S. H. Stow, 1505 , MS6038

57. G. W. Suter, 1505, MS6038

58. D. W. Swindle, K1330, MS7298

59. C. C. Travis, 4500S, MS6109

60. J. T. Trabalka, 1505, MS6036

61. R. R. Turner, 1505, MS6036

62. R. I. Van Hook, 1505, MS6037

63. K. Von Damm, 1505, MS6036

64. L. D. Voorhees, 1505, MS6036

65. S. H. Welch, 9115 , MS8219

66. R. K. White, 7509 , MS6383

67-68. Central Research Library

69-118. ER Document Management Center

119-121. ESD Library

121. Laboratory Records, RC

122. ORNL Patent Section

\section{EXTERNAL DISTRIBUTION}

123. Office of Assistant Manager for Energy Research and Development, DOE Field Office, Oak Ridge, P.O. Box 2001, Oak Ridge, TN 37831-8600

124. E. C. S. Amaral, Instituto de Radioprotefad E Dosimetria, Av. Das Americas Km 10.5, CEP 22602, Barra Da Tijuca, Rio de Janeiro, Brazil

125. L. R. Anspaugh, Environmental Sciences Division, Lawrence Livermore National Laboratory, University of California, P.O. Box 5507, L-453, Livermore, CA 94550

126. P. J. Barry, Chalk River Nuclear Laboratory, CRNL/AECL, Chalk River, Ontario K0J 1J0, Canada

127. Andre Bouville, Lead Scientist, U.S. Weapons Tests, National Cancer Institute, c/o Environmental Measurements Laboratory, 376 Hudson Street, New York, NY 10014

128. D. B. Chambers, SENES Consultant Limited, 52 West Beaver Creek Road, Unit No. 4, Richmond Hill, Ontario, LAB 1L9, Canada

129. P. H. Edmonds, Radian Corporation, 120 S. Jefferson Circle, Oak Ridge, TN 37830

130. C. Gist, DOE Field Office, Oak Ridge, P.O. Box 2001, Oak Ridge, TN 37831 
131. Helen Grogan, Intra-ECL, Highlands Farm, Greysroad, Henley-on-Thames, Oxon R.G9 4PS, U.K.

132. G. M. Hornberger, Professor, Department of Environmental Sciences, University of Virginia, Charlottesville, VA 22903

133. Gunnar Johanson, National Institute of Radiation Protection, Box 602 04, S-104 01, Stockholm, Sweden

134. T. Joseph, DOE Field Office, Oak Ridge, P.O. Box 2001, Oak Ridge, TN 37831

135. G. G. Killough, Notherland Road, Oak Ridge, TN 37830

136-139. W. E. Murphie, U.S. Department of Energy, Office of Environmental Restoration, Eastern Area D\&D Branch, EM-423 (GTN), Washington, DC 20545

140. R. S. Osborne, Chalk River Nuclear Laboratory, CRNL/AECL, Chalk River, Ontario K0J 1J0, Canada

141. D. G. Page, DOE Field Office, Oak Ridge, P.O. Box 2001, Oak Ridge, TN 37831-8541

142. R. John Pentreath, Ministry of Agriculture, Fisheries and Food (MAFF), Directorate of Fisheries Research, Fisheries Labor, Pakefield, Lowestoft Suffolk, NR33, OHT, U.K.

143-144. S. S. Perkins, DOE Field Office, Oak Ridge, Information Resource Center, 105 Broadway, Oak Ridge, TN 37830

145. Murray Schulman, Executive Assistant to the Director for Health and Environmental Research, U.S. Department of Energy, ER-70, Washington, DC 20545

146-162. R. C. Sleeman, Environmental Restoration Division, ER-12, DOE Field Office, Oak Ridge, P.O. Box 2001, Oak Ridge, TN 37831

163. W. L. Templeton, Battelle Pacific Northwest Laboratory, P.O. Box 999 (MS K1-30), Richland, WA 99352

164. J. R. Till, Radiological Assessment Corporation, Route 2, Box 122, Nesses, SC

165. W. F. Whicker, Department of Radiology and Radiation Biology, Rm 345, Colorado State University, Fort Collins, CO 10106

166-177. Office of Scientific and Technical Information, P.O. Box 62, Oak Ridge, TN 37831 

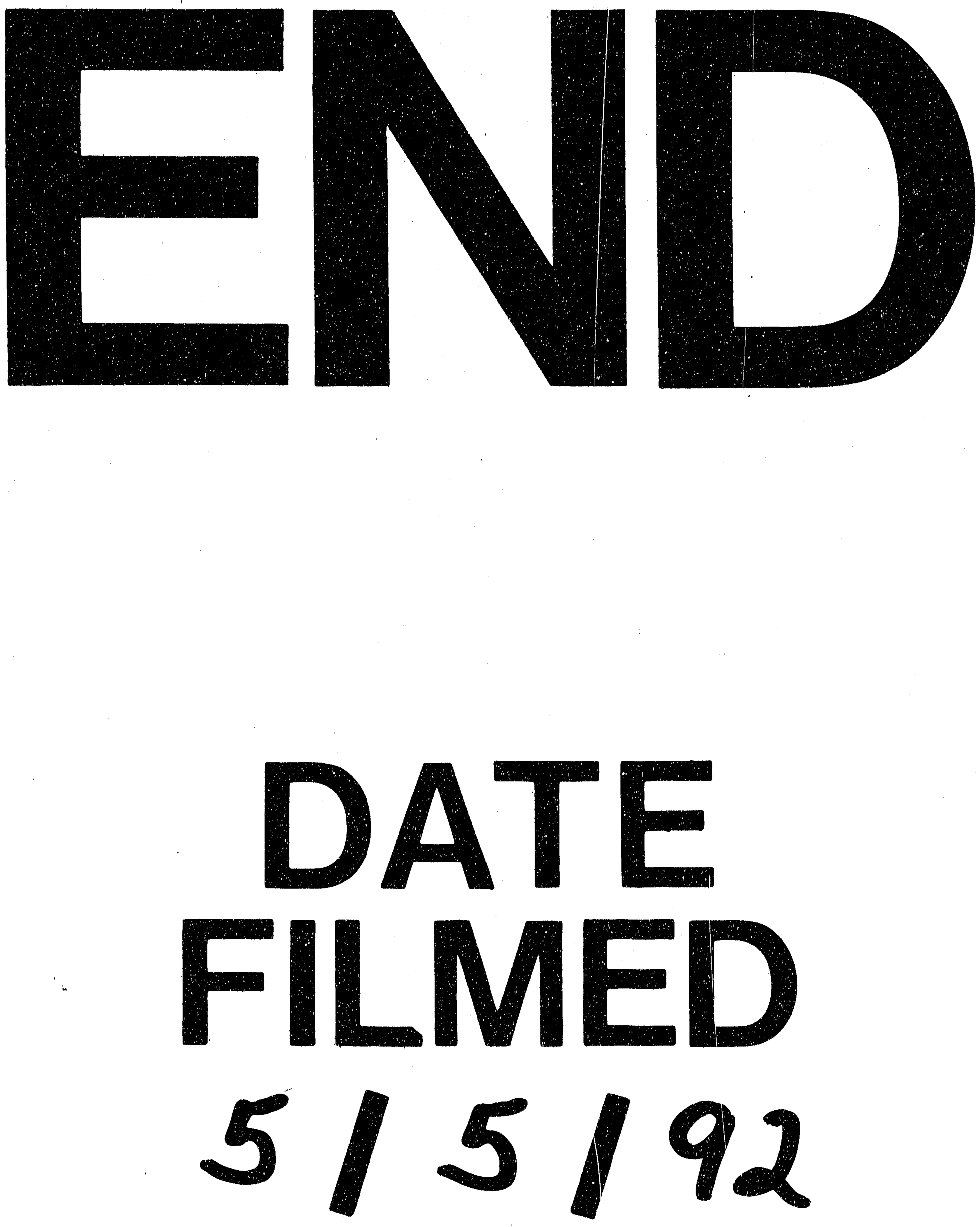

1 
